This document was prepared in conjunction with work accomplished under Contract No.

DE-AC09-96SR18500 with the U.S. Department of Energy.

\title{
DISCLAIMER
}

This report was prepared as an account of work sponsored by an agency of the United States Government. Neither the United States Government nor any agency thereof, nor any of their employees, makes any warranty, express or implied, or assumes any legal liability or responsibility for the accuracy, completeness, or usefulness of any information, apparatus, product or process disclosed, or represents that its use would not infringe privately owned rights. Reference herein to any specific commercial product, process or service by trade name, trademark, manufacturer, or otherwise does not necessarily constitute or imply its endorsement, recommendation, or favoring by the United States Government or any agency

thereof. The views and opinions of authors expressed herein do not necessarily state or reflect those of the United States Government or any agency thereof.

This report has been reproduced directly from the best available copy.

Available for sale to the public, in paper, from: U.S. Department of Commerce, National Technical Information Service, 5285 Port Royal Road, Springfield, VA 22161, phone: (800)

553-6847, fax: (703) 605-6900, email: orders@ntis.fedworld.gov online ordering: http://www.ntis.gov/ordering.htm

Available electronically at http://www.doe.gov/bridge

Available for a processing fee to U.S. Department of Energy and its contractors, in paper, from: U.S. Department of Energy, Office of Scientific and Technical Information, P.O. Box 62, Oak Ridge, TN 37831-0062, phone: (865 ) 576-8401, fax: (865) 576-5728, email: reports@ adonis.osti.gov 


\section{Mixing Envelope D Sludge with LAW Intermediate Products with and without Glass Formers}

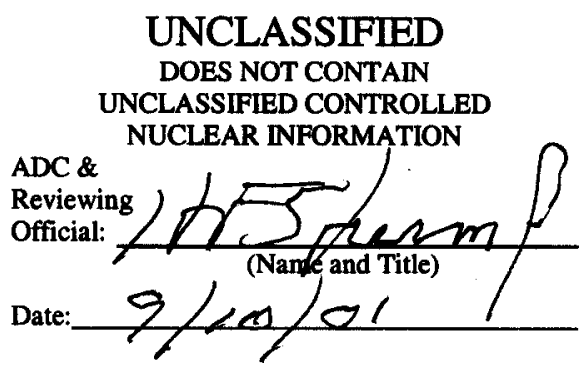

Disclaimer

This report was prepared by Westinghouse Savannah River Company (WSRC) for the United States Department of Energy under Contract No. DE-AC09-96SR18500 and is an account of work performed under that contract. Neither the United States Department of Energy, nor WSRC, nor any of their employees makes any warranty, expressed or implied, or assumes any legal liability or responsibility for accuracy, completeness, or usefulness, of any information, apparatus, or product or process disclosed herein or represents that its use will not infringe privately owned rights. Reference herein to any specific commercial product, process, or service by trade name, trademark, name, manufacturer or otherwise does not necessarily constitute or imply endorsement, recommendation, or favoring of same by WSRC or by the United States Government or any agency thereof. The views and opinions of the authors expressed herein do not necessarily state or reflect those of the United States Government or any agency thereof.

Westinghouse Savannah River Company

Savannah River Site

Aiken, SC 29808

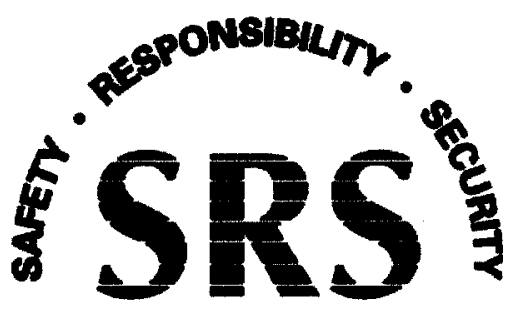

Prepared for the U.S. Department of Energy under Contract No. DE-AC09-96SR18500 
WSRC-TR-2001-00203, Rev. 0

SRT-RPP-2001-00051, Rev. 0

TRPT-24590-01-00001

\section{KEYWORDS:}

Rheology

Hanford River Protection Project

Simulants

Hanford Waste Tanks

RETENTION - Permanent

\section{Mixing Envelope D Sludge with LAW Intermediate Products with and without Glass Formers}

SAVANNAH RIVER TECHNOLOGY CENTER

E. K. Hansen, R. E. Eibling and T. B. Calloway, Jr.

Publication Date: September 2001

Westinghouse Savannah River Company

Savannah River Site

Aiken, SC 29808

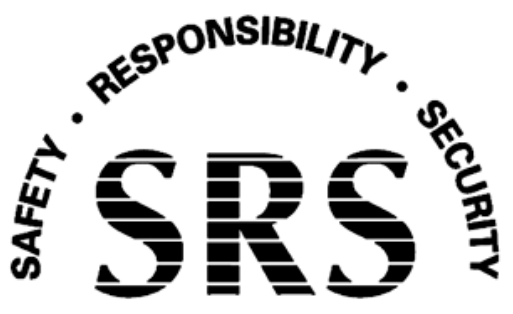

Prepared for the U.S. Department of Energy under Contract No. DE-AC09-96SR18500 
DOCUMENT:

TITLE:

APPROVALS
WSRC-TR-2001-00203, Rev. 0 (SRT-RPP-2001-00051, Rev. 0) TRPT-24590-01-00001

Mixing Envelope D Sludge with LAW Intermediate Products with and without Glass Formers

\section{Rusall S? Ribling}

Russell E. Eibling, Co-author (ITS/WTT/SRTC)

Date: $9-6-2001$

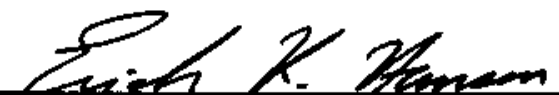

Date: $9-6-200 /$

E. K. Hansen, Co-author (ITS/YYTT/SRTC)
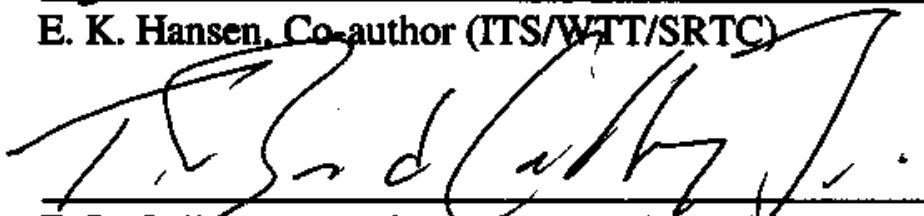

T. B. Calloway, Jr., Co-author (ITS/WTT/SRTC)

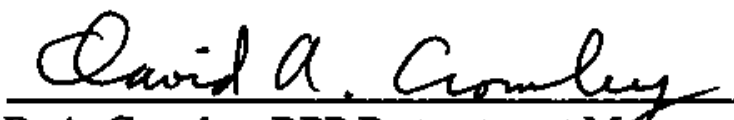

D. A. Crowley, RPP Pretreatment M/hager (ITS/WTT/SRTC)

Date: $9 / 6 / 01$

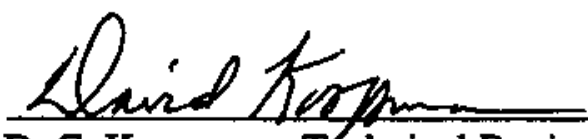

D. C. Koopman., TEchnical Reviewer (ITS/WTT/SRTC)

Date: $9 / 6 / 2001$ 
WSRC-TR-2001-00203, Rev. 0

SRT-RPP-2001-00051, Rev. 0

TRPT-24590-01-00001

\section{Executive Summary}

The Department of Energy (DOE) Office of River Protection is in the process of designing a waste treatment system to process the Hanford Reservation High Level Waste (HLW). Envelope D sludge slurries will be blended with the concentrated Cs/Tc eluates, and the Sr/TRU intermediates separated from Envelope A, B, and C feeds. The resulting blend (Envelope D + Eluates $+\mathrm{Sr} / \mathrm{TRU}$ precipitates) will be transferred to the HLW vitrification facility where glass formers will be added. This report documents the testing using waste simulants to obtain physical property and chemical composition data (e.g. rheology, elemental) on the expected HLW slurries that are generated during the blending of simulated sludges, eluates and Sr/TRU precipitates. Additionally, the resulting simulated HLW Melter slurries were also characterized for chemical and physical properties.

This study produced two washed simulated sludges (representing tanks 241-AZ-101 and 241AZ-102 sludge), a Sr/TRU washed precipitate produced from tank 241-AN-107 simulant, and a concentrated blended eluate simulant based upon eluates from processing 241-AZ-102 supernate. The physical properties and rheological properties of these individual products and their planned blends with and without glass formers were measured. Based upon these results the following conclusions were found.

- A comparison of the apparent viscosities of the simulated AZ-102 sludge to the actual AZ102 waste at a shear rate of 200 seconds $^{-1}$ indicates that the simulant's rheology behaves similarly to the real waste.

- Shearing reduces the particle size and modifies the particle size distribution for the simulated sludges and the Sr/TRU precipitate.

- Shearing the Sr/TRU precipitate reduced the yield stress of the precipitate.

- The rheological properties of the AZ-101 and AZ-102 simulated sludges and the Sr/TRU precipitate are distinctly nonnewtonian and can be represented by a Bingham flow model.

- As expected, the blended eluate simulant is a Newtonian fluid.

- The yield stress as determined by the vane method appears to agree well with the maximum observed using the concentric cylinder and cone and plate methods.

- The yield stress determined by using the Bingham model is a strong function of the insoluble solids loading for the AZ-101, AZ-102 simulated sludges and for the simulated AN-107 $\mathrm{Sr}$ /TRU precipitate which is consistent with results from other HLW slurries.

- The plastic viscosity or consistency of the simulated sludges based upon a Bingham flow model was relatively insensitive to the change in insoluble solids until the insoluble solids loading was above 18 to 19 weight percent.

Blending tests using actual fresh Hanford Envelope D waste should be conducted to determine if the yield stresses observed in this study are typical or bounding on the process. The use of caustic glass formers such as $\mathrm{LiOH}$ and $\mathrm{NaOH}$ can benefit the rheology of melter feed by reducing the yield stress of the feed. This study did not evaluate the effect of glass former particle size on rheology. Glass former particle size is known to have strong impact on rheology. Future melter feed rheology tests that vary the particle size of the glass formers should be conducted. 


\section{TABLE OF CONTENTS}

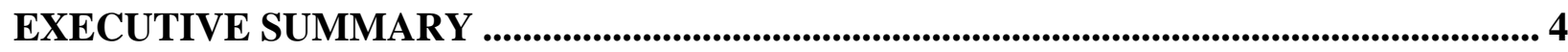

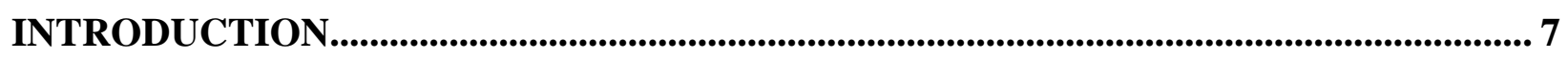

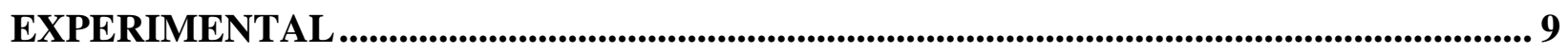

PHYSICAL AND RHEOLOGICAL MEASUREMENT METHODS ................................ 11

Solids, density, pH, particle size \& Titration...........................................................................................................................11

Rheology .......................................................................................................................................................................................13

RESULTS ............................................................................................................... 18

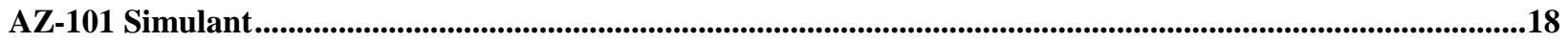

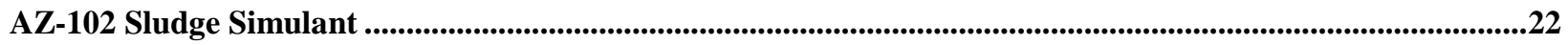

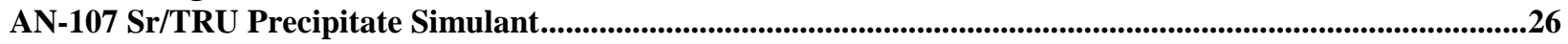

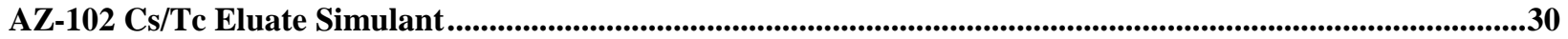

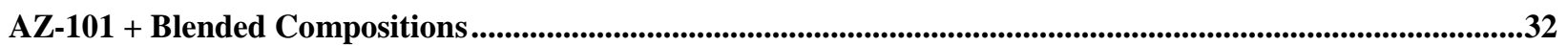

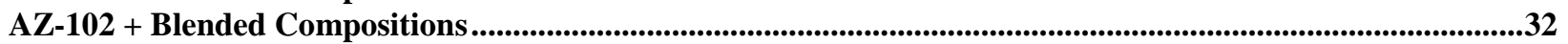

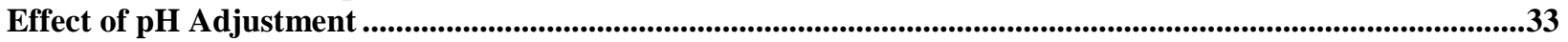

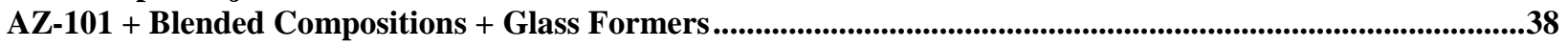

AZ-102 + Blended Compositions + Glass Formers .............................................................................39

CONCLUSIONS AND RECOMMENDATIONS.................................................................40

APPENDIX A: RHEOGRAMS AND PARTICLE SIZE RESULTS ..................................42

Table of Appendix A Figures .................................................................................................................................42

APPENDIX B: SIMULANT PREPARATION AND BLENDING ...................................... 74

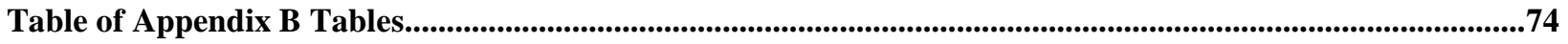

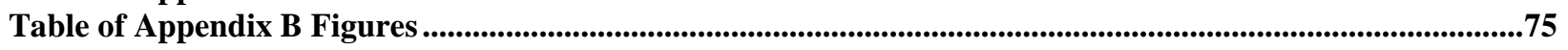

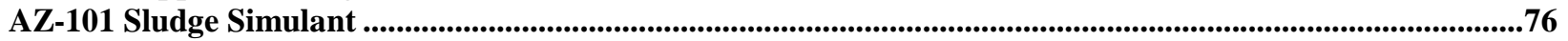

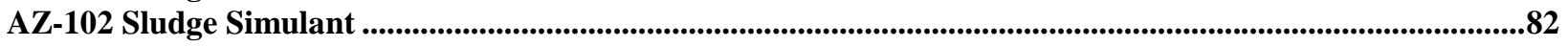

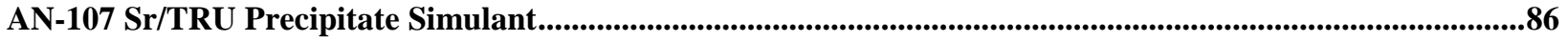

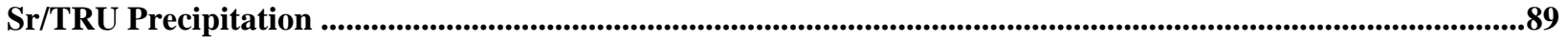

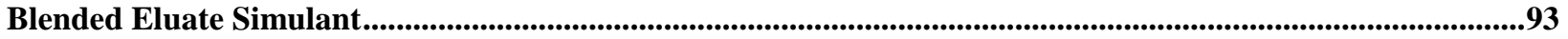

BLENDING BASIS FOR THE AZ-101 TEST MIXTURES ..........................................................96

Test 1.3...............................................................................................................................................................................98

Test 1.4...................................................................................................................................................................................................999

Test 1.5......................................................................................................................................................................103

Test ADD-1 ...........................................................................................................................................................104

Test ADD-2.....................................................................................................................................................105

BLENDING BASIS FOR THE AZ-102 TEST MIXTURES .............................................. 107

Test 2.3...................................................................................................................................................................................108

Test 2.4..................................................................................................................................................111

Test 2.5............................................................................................................................................................1111

Test 2.9...................................................................................................................................................................................113

Test ADD-3

Test ADD-4.................................................................................................................................................115

GLASS FORMULATIONS FOR AZ-101 ................................................................. 116

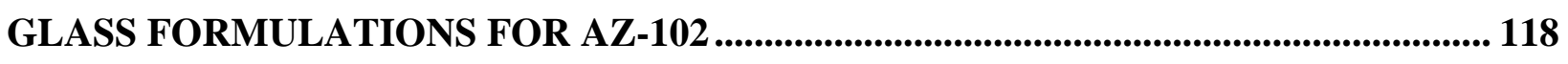


WSRC-TR-2001-00203, Rev. 0

\section{Table of Tables}

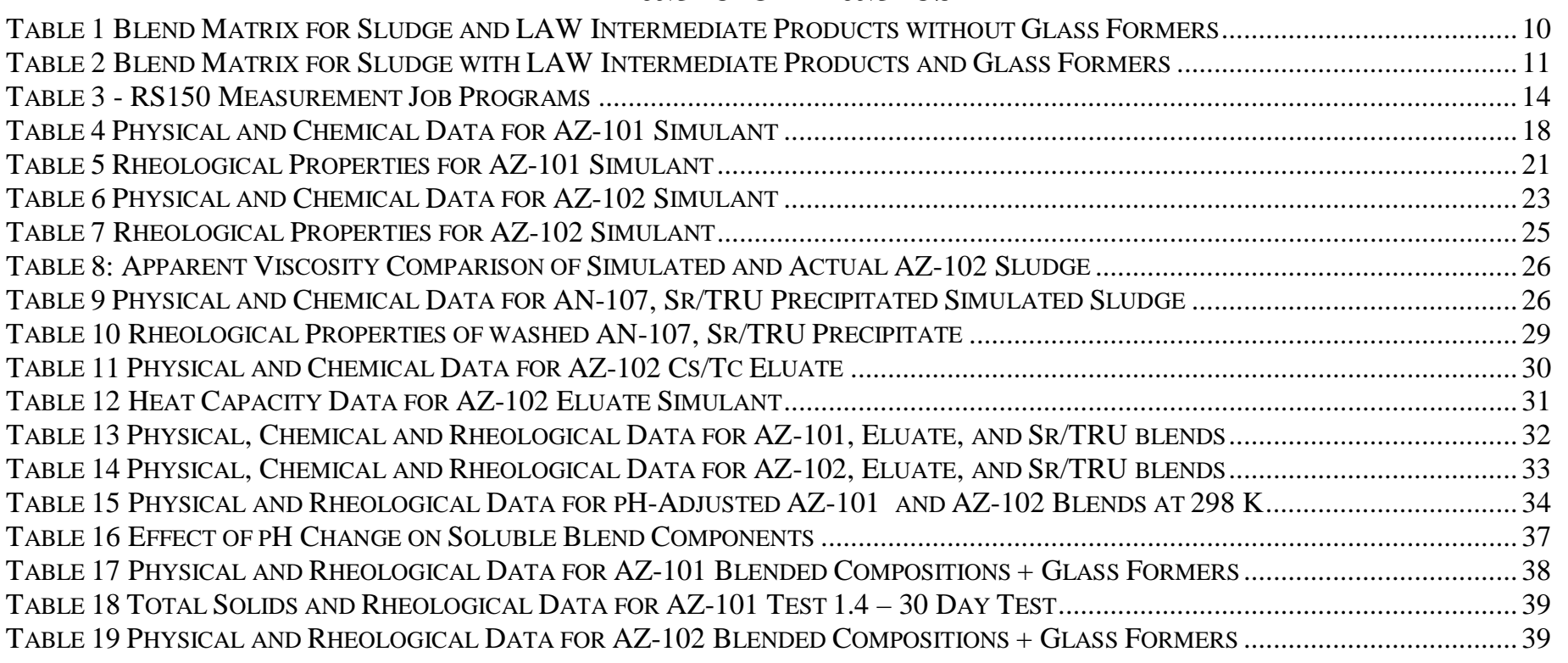

\section{TABLE OF Figures}

\begin{tabular}{|c|}
\hline FIGURE 2 VANE GEOMETRY MEASUREMENT DIMENSIONS ......... \\
\hline FIGURE 3 SiMULATED AZ-101, YIELD STRESS VERSUS WT. \% INSOLUBLE SOLIDS, $298 \mathrm{~K}$. \\
\hline FIGURE 4 SiMULATED AZ-101, YIELD STRESS VERSUS WT. \% INSOLUBLE SOLIDS, 323 K ...... \\
\hline 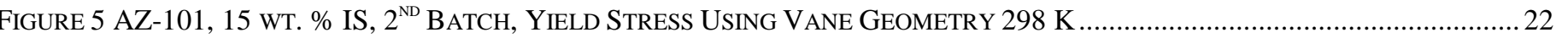 \\
\hline FIGURE 6 SiMULATED AZ-102, YIELD STRESS VERSUS WT. \% INSOLUBLE SOLIDS, 298 K ..... \\
\hline FIGURE 7 SIMULATED AZ-102, YIELD STRESS VERSUS WT. \% INSOLUBLE SOLIDS, $323 \mathrm{~K}$. \\
\hline 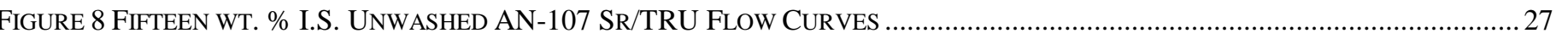 \\
\hline FIGURE 9 SIMULATED AN-107 SR/TRU PREC/WASHED, YIELD STRESS VS. WT. \% IS, $298 \mathrm{~K} . .$. \\
\hline 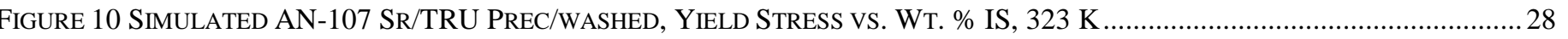 \\
\hline 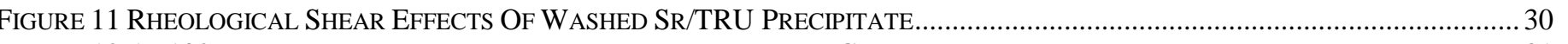 \\
\hline FIGURE 12 AZ102 ELUATE VISCOSITY VERSUS TEMPERATURE DATA - CURVE............. \\
\hline 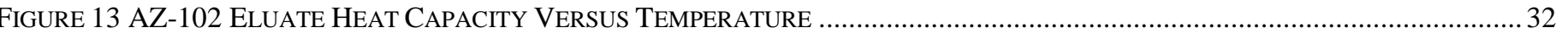 \\
\hline FIGURE 14 YIELD STRESS AS A FUNCTION OF PH AT 298 K................... \\
\hline FIGURE 15 CONSISTENCY AS A FUNCTION OF PH AT 298 K .... \\
\hline
\end{tabular}


WSRC-TR-2001-00203, Rev. 0

SRT-RPP-2001-00051, Rev. 0

TRPT-24590-01-00001

\section{Introduction}

The Department of Energy (DOE) Office of River Protection is in the process of designing a waste treatment system to process the Hanford Site High Level Waste (HLW). Westinghouse Savannah River Company - Savannah River Technology Center (WSRC-SRTC) is assisting in performing process testing and demonstrations for this effort. The design of the River Protection Project Waste Treatment Plant (RPP-WTP) Pretreatment facilities includes storage capacity for the Envelope D washed solids and the concentrated Cs/Tc eluates from LAW pretreatment. Envelope D sludge slurries will be blended with the concentrated $\mathrm{Cs} / \mathrm{Tc}$ eluates from processing Envelope A, B and C feeds and the Sr/TRU intermediates separated from C feeds. The resulting blend (Envelope D + Eluates $+\mathrm{Sr}$ /TRU precipitates) will be transferred to the HLW vitrification facility where glass formers will be added. The resulting HLW melter feed will be transferred to a joule-heated melter and vitrified into an acceptable waste form ${ }^{1}$. During initial startup of the RPP pretreatment and HLW vitrification facilities, the RPP-WTP pretreatment facilities will only produce washed Envelope D sludge slurries and $\mathrm{Cs} / \mathrm{Tc}$ eluate; therefore it is anticipated that the feed to the HLW vitrification facilities will be comprised of Envelope D sludge and concentrated $\mathrm{Cs} / \mathrm{Tc}$ eluate ${ }^{2}$.

RPP R\&T subcontractors (WSRC-SRTC and Battelle PNNL) have conducted R\&T testing activities that have characterized the expected concentration of simulated and actual washed Envelope D sludge slurries and the Sr/TRU precipitates modeling of the $\mathrm{Cs}$ and $\mathrm{Tc}$ eluate evaporators and the resulting blend of concentrated $\mathrm{Cs}$ and $\mathrm{Tc}$ eluates. Battelle PNNL and WSRC-SRTC are in the process of conducting tests with actual Envelope D (AZ-102) + Sr/TRU precipitates (AN-107) and eluate samples.

WSRC-SRTC has been requested by the RPP-WTP R\&T group to conduct laboratory scale testing of the expected blends of simulated Envelope D sludges (AZ-101 and AZ-102) + Cs/Tc Eluates (AZ-102) + Sr/TRU precipitates (AN-107) and Envelope D sludge (AZ-101 and AZ102) + Cs/Tc Eluates (AZ-102) as shown in Figure 1. Additionally, RPP R\&T has requested WSRC-SRTC to characterize the resulting Melter Feeds (Envelope D sludges + LAW Intermediates + Eluates + Glass Formers). This report documents the testing using waste simulants to obtain physical property and chemical composition data (e.g. rheology, elementals) on the expected HLW slurries that are generated during the blending of simulated sludges,

\footnotetext{
1 Page, M. et. al., Basis of Design, DB-W375-EG00001, Rev. 1, BNFL, Inc. River Protection Project Richland, WA, June 18, 1999.

2 Johnson, M. E. to Page, M., Interim Storage of Pretreated LAW Solution in the LAW Feed Receipt Vessels (System PT-110), CCN\#: 011389, BNFL Inc. River Protection Project, Richland WA, February 17, 2000.

${ }^{3}$ Hallen, R. T. et. al., Combined Entrained Solids and Sr/TRU Removal from Diluted AN107 Diluted Feed, BNFL-RPT-027 Rev. 0 Draft, Battelle Memorial Laboratories Richland WA, February 2000

4 Duignan, M. R., Final Report: Pilot-scale Cross-flow Ultrafiltration Test Using Hanford Site Tank 241-An107 Waste Simulant - Envelope C + Entrained Solids + Strontium-Transuranic Precipitation, BNF-003-98-0226, Westinghouse Savannah River Company, Savannah River Site, Aiken SC, March 24, 2000.

5 Morrey, E. V. et. al., Comparison of Simulants to Actual Neutralized Current Acid Waste: Process and Product Testing of Three NCAW Core Samples from Tanks 101-AZ and 102-AZ, Pacific Northwest National Laboratory, Richland WA October 1996.

${ }^{6}$ Work For Others Agreement No. WFO-98-003 Between Westinghouse Savannah River Company, Inc. Operating under Prime Contract No. DE-AC09-96SR18500 for the U. S. Department of Energy and BNFL, Inc.
} 
WSRC-TR-2001-00203, Rev. 0

eluates and precipitates as shown in Figure 1. Additionally, the simulated HLW slurries were also characterized after glass formers had been added.

\section{Figure 1 Flow Chart of Sludge, Eluate and Sr/TRU precipitate Blends}

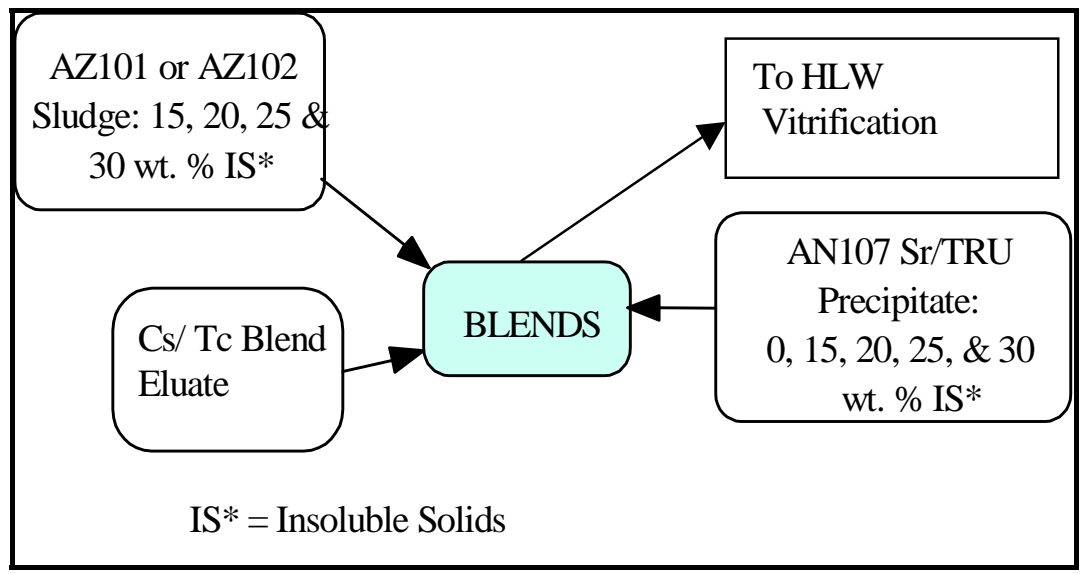

The objectives of this task are to provide information on the behavior (physical and chemical composition) of HLW slurries, following blending of the washed Envelope D slurries with Cs/Tc eluates and Sr/TRU precipitates and on the expected Melter Feeds derived from these blends The research described in this report was conducted under task plan WSRC-RP-2000-00731. The RPP flow sheet for filtration of Envelope D and the Sr/TRU precipitates assumes these slurries can be concentrated to approximately 20 weight $\%$ insoluble solids. However, to properly bound the design and operation of the filters, downstream piping systems, storage vessels and vitrification mixing systems, testing with insoluble solids contents ranging from 15 to 30 weight $\%$ was to be performed by WSRC-SRTC 8 . The composition of the blended slurries used in this study was based upon glass formulations provided by VSL

Initial modeling results from WSRC-SRTC have indicated that the blended Cs/Tc eluate is slightly alkaline ${ }^{10}$. Washed Envelope D sludge and Sr/TRU precipitate slurries are also alkaline. Since HLW melter feed slurries processed by other DOE vitrification facilities have traditionally been slightly acidic in nature, WSRC-SRTC will test various Envelope D/Eluate/Sr/TRU slurries with nitric acid and determine the effects of $\mathrm{pH}$ on the physical and chemical composition. Past research conducted by DOE subcontractors indicates that HLW slurries that have been acidified are less viscous and have lower yield stresses $\frac{11.12}{2}$

\footnotetext{
${ }^{7}$ Hansen, E. K., et. al., Task Technical and Quality Assurance Plan for Mixing Envelope D Sludge with LAW Intermediate Products (Sr/TRU Precipitate and Cs/TC Eluate) with and without Glass Formers, WSRC-RP-2000-00731, SRT-RPP-2000-00002, Westinghouse Savannah River Company, Aiken SC, October 3, 2000.

8 Johnson, M. E. to Calloway, T. B., Re: Sludge/Sr-TRU/Eluate Mixing, Email, BNFL, Inc. River Protection Project, Richland WA, 4/13/00

${ }^{9}$ VSL glass formulations are listed in Appendix B, Tables B - 41 and B -42.

10 Choi, A. S. to Johnson, Estimation of Physical Properties of Tank 241-AN107 Cesium and Technetium Eluate Concentrate Blend, Email, Westinghouse Savannah River Company, Aiken, SC, 2/22/00

11 Fowler, J. R., Rheology of Synthetic Feed for the Slurry-Fed Melter, DPST-91-491, E. I. DuPont de Nemours \& Co., Savannah River Laboratory, Aiken SC, June 29, 1981

12 Smith, P. A., The Effects of Formic Acid and Nitric Acid on Simulated Hanford Neutralized Current Acid Waste Rheology, PNNL-12052, Pacific Northwest Laboratory, Richland WA 99352, Unpublished copy Forwarded to WSRC from BNFL, 2/22/98
} 
WSRC-TR-2001-00203, Rev. 0

The RPP vitrification flow sheet does not currently acidify the Melter Feed (waste + glass formers) slurries. Therefore, this task will only test Melter Feeds that have not been acidified. If significant process/costs benefits can be achieved by acidifying the slurry during Pretreatment, RPP may choose to test Melter Feed slurries that have been acidified.

\section{Experimental}

The original task ${ }^{7}$ specified testing the AZ101 and AZ102 sludge simulants from a insoluble solids content of 10 to 30 weight percent (wt. \%), in $5 \mathrm{wt}$ \% increments. The sludge simulants were blended with the blended AZ-102 Cs/Tc eluate simulant and an AN-107 Sr/TRU precipitate simulant followed by tests with and without glass formers as shown in Table 1 and Table 2 respectively. Table 1 also provides waste streams that were to be acidified with nitric acid. Table 2 also includes 30 day extended mixing tests to determine if the glass formers will impact the rheological properties of the slurry over time. The blended combination of sludgewith eluate and Sr/TRU precipitate and extended mixing tests were agreed upon in the Task Plan 7 . These blending ratios may not necessarily be the actual ratios of real sludge to that of LAW waste streams in the pretreatment plant. Additionally, the glass former chemicals used in these experiments were based on these pre-blending ratios, hence the ratio and type of glass formers may not necessarily be the same used in the vitrification plant.

The targeted wt. \% insoluble solids were obtained by centrifuging (at 4333 g's) the base sludges and then decanting a calculated amount of supernate. During the processing of the AZ101 and AZ102 sludge simulants to their targeted wt. \% insoluble concentrations, it was determined that the AZ101 sludge simulant could only be concentrated to $21 \mathrm{wt}$. $\%$ insoluble solids and the AZ102 sludge simulant to 27 wt. \% insoluble solids, via centrifuging. These limiting sludges were based on completely decanting all the supernate upon centrifuging a sample of the base sludge, hence no standing liquid was remaining. The limiting sludges were then blended at a very high shear rate and allowed to sit to determine if any residual liquid would form, none did. The only other method to increase the wt. \% insoluble solids is via drying, but this was not attempted, since this would only make the sludge thicker. The $25 \mathrm{wt}$. \% insoluble solids AZ102 sludge simulant was also determined to be unrealistic for processing, when visually comparing it to the AZ101 sludge simulant at $20 \mathrm{wt}$. \% insoluble solids. Hence, the original scope was drastically reduced, by eliminating all blended combinations above $20 \mathrm{wt}$. \% insoluble solids for both AZ101 and AZ102 sludge simulant. Two lower wt. \% insoluble solids concentrations were added and are shown in the Test Number column as ADD items. These ADD items were not part of the original task plan, but were added at the discretion of the researchers. Table 1 and Table 2 have been high-lighted to reflect these changes by yellow boxing items removed from the scope of work and green boxing items that were added to the scope of work. All items completed in Table 1 and Table 2 are bolded. 
WSRC-TR-2001-00203, Rev. 0

SRT-RPP-2001-00051, Rev. 0 TRPT-24590-01-00001

Table 1 Blend Matrix for Sludge and LAW Intermediate Products without Glass Formers

\begin{tabular}{|c|c|c|c|c|}
\hline \multirow[b]{2}{*}{ Test No. } & \multicolumn{2}{|c|}{ Envelope D Simulant } & \multirow{2}{*}{$\begin{array}{c}\text { Sr/TRU Precipitate } \\
\text { Slurry Addition AN107 } \\
\text { Insoluble Solids } \\
\text { Concentration }(\%)^{*}\end{array}$} & \multirow{2}{*}{$\begin{array}{l}\mathrm{pH} \text { Adjustment (After } \\
\text { Initial Mixture } \\
\text { Characterization- with } \\
\mathrm{HNO}_{3} \text { ) }\end{array}$} \\
\hline & Simulant & $\begin{array}{c}\text { Insoluble Solids } \\
\text { Concentration } \\
(\%)\end{array}$ & & \\
\hline 1.1 & AZ101 & 30 & 30 & Yes \\
\hline 1.2 & $\mathrm{AZ101}$ & 25 & 25 & Yes \\
\hline 1.3 & AZ101 & 20 & 20 & Yes \\
\hline 1.4 & AZ101 & 15 & 15 & Yes \\
\hline 1.5 & AZ101 & 15 & 25 & Yes \\
\hline 1.6 & $\mathrm{AZ101}$ & 25 & 15 & Yes \\
\hline 1.7 & AZ101 & 30 & 0 & Yes \\
\hline 1.8 & AZ101 & 25 & 0 & Yes \\
\hline 1.9 & AZ101 & 20 & 0 & Yes \\
\hline 1.10 & AZ101 & 15 & 0 & No \\
\hline ADD-1 & AZ101 & 7.5 & 15 & No \\
\hline ADD-2 & AZ101 & 10 & 15 & No \\
\hline 2.1 & $\mathrm{AZ102}$ & 30 & 30 & Yes \\
\hline 2.2 & $\mathrm{AZ102}$ & 25 & 25 & Yes \\
\hline 2.3 & AZ102 & 20 & 20 & Yes \\
\hline 2.4 & AZ102 & 15 & 15 & No \\
\hline 2.5 & AZ102 & 15 & 25 & Yes \\
\hline 2.6 & AZ102 & 25 & 15 & Yes \\
\hline 2.7 & AZ102 & 30 & 0 & Yes \\
\hline 2.8 & AZ102 & 25 & 0 & Yes \\
\hline 2.9 & AZ102 & 20 & $\mathbf{0}$ & Yes \\
\hline 2.10 & AZ102 & 15 & 0 & No \\
\hline ADD-3 & AZ102 & 10 & 15 & No \\
\hline ADD-4 & AZ102 & 12.5 & 15 & No \\
\hline
\end{tabular}

*Eluate is added to All Blends

Items highlighted in Yellow were not tested

Items highlighted in Green were added for additional data, without titration 
Table 2 Blend Matrix for Sludge with LAW Intermediate Products and Glass Formers

\begin{tabular}{|c|c|c|c|c|}
\hline \multirow[b]{2}{*}{ Test No. } & \multicolumn{2}{|c|}{ Envelope D Simulant } & \multirow{2}{*}{$\begin{array}{c}\text { Sr/TRU Precipitate Slurry } \\
\text { Addition AN107 } \\
\text { Insoluble Solids } \\
\text { Concentration }(\%)^{*} \\
\end{array}$} & \multirow[b]{2}{*}{$\begin{array}{c}30 \text { Day Melter } \\
\text { Feed Stability } \\
\text { Test }\end{array}$} \\
\hline & Simulant & $\begin{array}{c}\text { Insoluble Solids } \\
\text { Concentration } \\
(\%)\end{array}$ & & \\
\hline 1.1 & AZ101 & 30 & 30 & Yes \\
\hline 1.2 & AZ101 & 25 & 25 & No \\
\hline 1.3 & AZ101 & 20 & 20 & No \\
\hline 1.4 & AZ101 & 15 & 15 & Yes \\
\hline 1.5 & AZ101 & 15 & 25 & No \\
\hline 1.6 & AZ101 & 25 & 15 & No \\
\hline 1.7 & AZ101 & 30 & 0 & No \\
\hline 1.8 & AZ101 & 25 & 0 & No \\
\hline 1.9 & AZ101 & 20 & 0 & No \\
\hline 1.10 & AZ101 & 15 & 0 & No \\
\hline ADD-1 & AZ101 & 15 & $\mathbf{0}$ & No \\
\hline ADD-2 & AZ101 & 15 & $\mathbf{0}$ & No \\
\hline 2.1 & AZ102 & 30 & 30 & No \\
\hline 2.2 & AZ102 & 25 & 25 & $\mathrm{No}$ \\
\hline 2.3 & AZ102 & 20 & 20 & No \\
\hline 2.4 & AZ102 & 15 & 15 & No \\
\hline 2.5 & AZ102 & 15 & 25 & No \\
\hline 2.6 & AZ102 & 25 & 15 & No \\
\hline 2.7 & AZ102 & 30 & 0 & No \\
\hline 2.8 & $\mathrm{AZ102}$ & 25 & 0 & No \\
\hline 2.9 & AZ102 & 20 & $\mathbf{0}$ & No \\
\hline 2.10 & AZ102 & 15 & 0 & No \\
\hline ADD-3 & $\mathbf{A Z 1 0 2}$ & 10 & 15 & No \\
\hline ADD-4 & AZ102 & 12.5 & 15 & No \\
\hline
\end{tabular}

* Eluate is Added to all Blend

Items highlighted in Yellow were not tested

Items highlighted in Green were added for additional data, without titration

The basis, formulation and production of the AZ-101 and AZ-102 simulated sludges, the Sr/TRU precipitate simulant, and the blended AZ-102 Cs/TC eluate simulant are described in Appendix B. The basis for waste stream blending and for the glass former additions is also described in Appendix B.

\section{Physical and Rheological Measurement Methods}

\section{Solids, density, pH, particle size \& Titration}

The weight percent solids were determined by oven drying the samples between $105-115^{\circ} \mathrm{C}$ overnight or using a CEM microwave moisture/solids analyzer. The homogenous sample (slurry or liquid) is then placed on a microwave pad or in an oven crucible and weighed, the mass of the sample used is considered as the total mass $\left(\mathrm{m}_{\mathrm{tt}}\right)$. The sample is then placed into the 
WSRC-TR-2001-00203, Rev. 0

oven/microwave to drive off all the water and the resulting remaining mass is the total solids $\left(\mathrm{m}_{\mathrm{ts}}\right)$ in the sample. The wt. \% total solids (TS) was determined using equation [1].

$$
w t \%_{t s}=\frac{m_{t s}}{m_{t t}} \times 100 \%
$$

A sample of the slurry is centrifuged (at $42500 \mathrm{~m} / \mathrm{s}^{2}$ ) to obtain the supernate. The resulting supernate is then processed through a $0.45 \mu \mathrm{m}$ filter. Any particle smaller than $0.45 \mu \mathrm{m}$ is assumed to be part of the supernate. A sample of this supernate is then placed on a microwave pad or in an oven crucible and weighed, the mass of sample used is considered as the total mass of the supernate $\left(\mathrm{m}_{\mathrm{st}}\right)$. The sample is then placed into the oven/microwave to drive off all the water and the resulting remaining mass is the total dissolved solids $\left(\mathrm{m}_{\mathrm{ds}}\right)$ in the supernate. The weight percent of total dissolved solids in the supernate is determined using equation [2]. Again, this analysis assumes that all the solids in the resulting supernate are dissolved.

$$
w t \%_{d s}=\frac{m_{d s}}{m_{s t}} \times 100 \%
$$

The weight percent of insoluble solids (IS) and soluble solids (SS) of the slurry can then be determined by the following conservation of mass relationships, equations [3] and [4] respectively.

$$
\begin{aligned}
& w t \%_{i s}=\frac{w t \%_{t s}-w t \%_{d s}}{100 \%-w t \%_{d s}} \cdot 100 \% \\
& w t \%_{s s}=w t \%_{t s}-w t \%_{i s}
\end{aligned}
$$

Weight percent calcine solids is obtained by calcining a known mass of sample at $1223 \mathrm{~K}$ for two hours, cooling in a dessicator, and obtaining the calcined weight. The calcine factor is calculated by dividing the calcine weight percent solids by the weight percent total solids.

Density measurements were made using a specific gravity cup and cap unit (pycnometer). The cup/cap was first tared using a calibrated weigh scale. The sample was placed into the cup and then the cap was used to press out excess sample and the excess sample removed. The mass of the cup/sample/cap was then measured on the calibrated weigh scale. The density of the slurry or eluate was then determined by dividing this mass by the known volume of the cup/cap unit $\left(8.321 \mathrm{~cm}^{3}\right)$. The volume of the cup was verified using deionized water. All density measurements were made at normal laboratory temperatures, 293-295 K, unless otherwise specified.

Measurements of $\mathrm{pH}$ were made using a Fisher Scientific Accumet ${ }^{\circledR}$ model $15 \mathrm{pH}$ meter. The instrument was calibrated using $\mathrm{pH} 4$ and $\mathrm{pH} 10$ buffer solutions, and then checked against a $\mathrm{pH}$ 7 buffer. Indicated instrument results were within $0.1 \mathrm{pH}$ unit for the $\mathrm{pH} 7$ buffer. 
WSRC-TR-2001-00203, Rev. 0

Particle size distributions were measured using a MicroTrac-SRA150 particle analyzer. Light from a laser passes through a sample cell and produces a diffraction pattern, in which the intensity is measured. A proprietary algorithm in the MicroTrac software analyzes the measured intensity profile. The reported results assume that the particles are spherical in nature. The analyzer is calibrated every 6 months by the vendor.

\section{Rheology}

Slurry rheology was characterized using both Haake RV20 (with an M5 measuring head) and Haake RS150 rheometers. Both rheometers are Searle type measuring systems, where both the speed and torque are measured at the rotating shaft.

The RV20 rheometer is a controlled rate (where the shear rate is applied and the resulting shear stress is measured) rheometer. A concentric cylindrical geometry was used to measure the flow properties using the RV20. The MV1 stainless steel cylindrical rotor (40.08-mm outside diameter, 60-mm length), with a recessed bottom to reduce end effects, was the inner cylinder. The MV1 rotor was then attached to the M5 measuring head driver motor. A slurry sample was placed into a cylindrical stainless cup (42-mm inside diameter) and loaded into the heating jacket. The heating jacket controlled the temperature of the rotor, sample and cup. A heating/cooling temperature bath was attached to the heating jacket to provide the heat sink. All measurements were taken at $298 \mathrm{~K}$. All rheology measurements were taken using a linear shear rate ramp from 0 to $350 \mathrm{sec}^{-1}$ in five minutes, holding the shear rate at $350 \mathrm{sec}^{-1}$ for two minutes, and then linearly decreasing the shear rate from 350 to $0 \mathrm{sec}^{-1}$ in five minutes.

The RS150 rheometer can be controlled using either the controlled rate or controlled stress modes. In this study, only the controlled rate mode was used. Cone and plate geometry, listed in Table 3 was used to obtain all the flow curves. Flow curves were obtained using a $60-\mathrm{mm}$ stainless steel measuring plate that was initially attached to the plate-heating jacket. The $60-\mathrm{mm}$ cone with a vapor trap was attached to the RS150. The RS150, controlled via software, initially finds the zero point (distance between the cone and measuring plate is zero) and then the sample is loaded onto the measuring plate. A gap setting (distance between the cone and measuring plate) as determined by the vendor and listed in Table 3. was obtained using the RS150 software, given the specified cone geometry. Excess sample was trimmed from the exposed edge to minimize end effects. Water ( 3 to 5 degrees Kelvin above the measured temperature) was added to the vapor trap reservoir to try to maintain vapor space humidity, since these slurries had a tendency to evaporate during the measurement around the exposed edge. A heating/cooling temperature bath was attached to the plate-heating jacket to provide the heat sink. All measurements were taken at $298 \mathrm{~K}$ and $323 \mathrm{~K}$ for the sludge/slurry and from $293 \mathrm{~K}$ to $353 \mathrm{~K}$ in 10 degree increments for the eluate. 
WSRC-TR-2001-00203, Rev. 0

SRT-RPP-2001-00051, Rev. 0

TRPT-24590-01-00001

Table 3 - RS150 Measurement Job Programs

\begin{tabular}{|c|c|c|c|c|}
\hline \multirow{2}{*}{ Material } & \multirow{2}{*}{ Geometry } & Linear shear rate ramp (up) & Holding shear rate & Linear shear rate ramp (down) \\
\hline & & range \& time & range $\&$ time & range \& time \\
\hline $\begin{array}{l}\text { Sludge - } \\
\text { Slurry }\end{array}$ & $\begin{array}{c}\text { Cone-Plate } \\
2^{\circ} 60-\mathrm{mm} \text { cone } \\
\text { Gap }=0.107-\mathrm{mm}\end{array}$ & $0 \leq \underset{A}{ } \leq \frac{1000 \mathrm{sec}^{-1}}{5 \mathrm{~min}}$ & $\begin{aligned} \dot{A}= & 1000 \sec ^{-1} \\
& 2 \mathrm{~min}\end{aligned}$ & $1000 \geq \underset{5 \mathrm{~min}}{\mathrm{~A}} \geq 0 \mathrm{sec}^{-1}$ \\
\hline $\begin{array}{l}\text { Sludge - } \\
\text { Slurry }\end{array}$ & $\begin{array}{c}\text { Cone-Plate } \\
2^{\circ} 60-\mathrm{mm} \text { cone } \\
\text { Gap }=0.107-\mathrm{mm}\end{array}$ & $0 \leq \underset{A}{ } \leq 2000 \mathrm{sec}^{-1}$ & $\begin{aligned} A= & 2000 \sec ^{-1} \\
& 2 \mathrm{~min}\end{aligned}$ & $2000 \geq \underset{5 \min }{A} \geq 0 \sec ^{-1}$ \\
\hline Sludge & $\begin{array}{c}\text { Vane FL-22, } \\
\mathrm{D}=22-\mathrm{mm} \\
\mathrm{H}=16-\mathrm{mm}\end{array}$ & Varied rotational speed from & $\begin{array}{l}.001 \text { to } 0.04 \mathrm{radian} / \mathrm{s} \\
\text { maximum stress. }\end{array}$ & Time was varied to obtain the \\
\hline Eluate & $\begin{array}{c}\text { Cone-Pate } \\
0.5^{\circ} 60-\mathrm{mm} \text { cone, } \\
\text { gap }=0.029-\mathrm{mm}\end{array}$ & $\begin{array}{c}0 \leq \mathrm{A} \leq 2000 \mathrm{sec}^{-1} \\
20 \mathrm{~S} / \mathrm{S} \text { readings }\end{array}$ & $\begin{array}{c}\hat{A}=2000 \mathrm{sec}^{-1} \\
10 \mathrm{sec}\end{array}$ & $\begin{array}{c}2000 \geq \hat{A} \geq 0 \sec ^{-1} \\
20 \mathrm{~S} / \mathrm{S} \text { readings }\end{array}$ \\
\hline
\end{tabular}

The yield stress of one of the sludge samples was analyzed using vane FL-22 geometry. The dimensions of the vane are provided in Table 3 . The vane was placed into a cup with an inside diameter of 43.4-mm and the temperature of the sample was maintained at $298 \mathrm{~K}$ using the heating/cooling temperature bath. The location of the vane and the amount of sample used was based on work performed by Dzuy and Boger 13 . The location of the vane and minimal physical dimensions as recommended by Dzuy and Boger are shown in Figure 2. All the dimensions were met other than $\mathrm{D}_{\mathrm{T}} / \mathrm{D}$, which in this case was 1.97 .

13 N. Q. Dzuy and D. V. Boger, Direct Yield Stress Measurement with the Vane Method, Journal of Rheology, Volume 29, 335-347, 1985 


\section{Figure 2 Vane Geometry Measurement Dimensions}

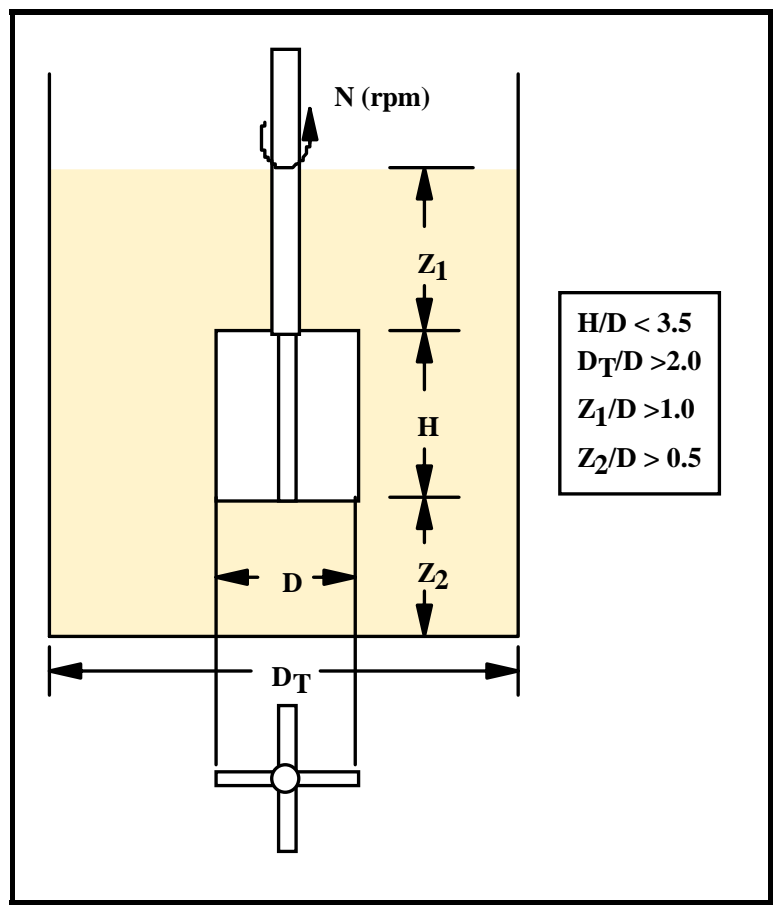

Both the RV20 and RS150 rheometers were functionally checked using a $102.5 \mathrm{mPa}$-sec silicone oil standard at $298 \mathrm{~K}$ on each day that the instruments were used for measurement. Results for the standards were always within $\pm 5 \%$. The RS150 measuring plate was checked on a weekly basis to verify the measuring surface was level.

The resulting uncorrected flow curves obtained from both the cylindrical and cone/plate geometry's have not been corrected for slip, viscous/thermal effects, or end effects. No secondary flow problems, such as Taylor vortices were noted in any of these measurements. Since no corrections were performed, the flow curves from the cylindrical and cone/plate geometry's may not necessarily produce the same results. A standard method of correcting cone/plate results for slip was not available.

The uncorrected flow curves for the sludges and slurries were modeled using the Bingham Plastic rheological model, equation [5]. The eluate was modeled using Newton's equation [6].

$$
\begin{aligned}
& \tau=\tau_{o}+\eta \dot{\gamma} \\
& \tau=\mu \dot{\gamma}
\end{aligned}
$$

Where: $\tau_{o}=$ Bingham plastic yield stress $(\mathrm{Pa})$

$\tau=$ Shear stress $(\mathrm{Pa})$

$\dot{\gamma}=$ Shear rate $\left(\mathrm{sec}^{-1}\right)$

$\eta=$ Bingham Plastic consistency or Bingham plastic viscosity (mPa-sec)

$\mu=$ Newtonian viscosity (mPa-sec) 
WSRC-TR-2001-00203, Rev. 0

SRT-RPP-2001-00051, Rev. 0

TRPT-24590-01-00001

The flow curves obtained from the RV20 were fitted between 100 to $1000 \mathrm{sec}^{-1}$ using equation [5]. For the RS150, the flow curves for the sludges and slurries were fitted between 100 to 1000 $\mathrm{sec}^{-1}$, unless otherwise noted and specified using equation [5]. For the eluate, the flow curves were fitted between 0 to $2000 \mathrm{sec}^{-1}$ using equation [5].

Marek ${ }^{14}$ modeled the two Bingham fluid parameters, as a function of wt. \% insoluble solids (IS) and wt \% total solids (TS) content of the slurry. The original theoretical model described the "apparent viscosity" of a Newtonian slurry as a function of the volume fraction of insoluble solids. This equation 15 has been modified and used by Marek to model both the Bingham Plastic yield stress and consistency as a function of wt. \% IS concentration of the slurry and are shown as equations [6] and [7]. In this report, the dependence of yield stress and consistency on wt. \% TS concentration will also be determined using equations [6] and [7]. The unknown parameters in equations [6] and [7] were obtained using Table Curve 2D software 4.01.

$$
\begin{aligned}
& \tau_{o}=A_{1} \frac{\exp ^{b_{1}{ }^{*} C}}{\left(1-C / C_{\max , 1}\right)} \\
& \eta=A_{2} \frac{\exp ^{b_{2}{ }^{*} C}}{\left(1-C / C_{\max , 2}\right)}
\end{aligned}
$$

Where: $\tau_{o}=$ yield stress from the Bingham Plastic model $(\mathrm{Pa})$

$\eta \quad=$ consistency (plastic viscosity) from the Bingham Plastic model (mPa-sec)

$C=$ insoluble solids concentration (wt. \%)

$A_{i} \quad=$ modeled parameter $\left(\right.$ dynes $/ \mathrm{cm}^{2}$ or $\left.\mathrm{mPa}-\mathrm{sec}\right)$

$C_{\text {max }, \mathrm{i}}=$ modeled parameters corresponding to maximum wt. $\%$ insoluble solids

$b_{\mathrm{i}}=$ modeled parameters $(\text { wt. } \%)^{-1}$

The yield stress, using the vane method was determined using equation [8]. Equation [8] assumes that thesstress is uniformly distributed over both surface ends and at the cylindrical wall

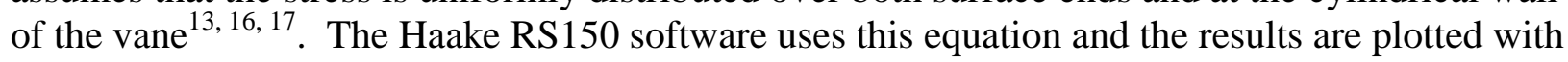
stress versus time. The maximum measured stress is congidered as the yield stress (called the dynamic yield stress 16

$$
\tau_{o}=\frac{T_{m}}{K}, K=\frac{\pi D^{3}}{2}\left(\frac{H}{D}+\frac{1}{3}\right)
$$

Where: $\tau_{o}=$ yield stress $(\mathrm{Pa})$

$D \quad=$ diameter of the vane $(\mathrm{m})$

$H \quad=$ height of the vane $(\mathrm{m})$

$T_{m} \quad=$ Torque $(\mathrm{N}-\mathrm{m})$.

\footnotetext{
14 J. C. Marek, Rheology Measurements of Simulated Slurry Mix Evaporator Material (U), WSRC-TR-97-00343, Rev. 0, October 17, 1997

15 C. A. Shook and M. C. Roco, Slurry Flow - Principles and Practice, Butterworth-Heinemann, pp. 61-64, 1991

${ }^{16}$ P. V. Liddell and D. V. Boger, Yield Stress Measurements with the vane, Journal of Non-Newtonian Fluid Mechanics, Vol. 63, pp. 235 261,1996

17 N. J. Alderman, G. H. and J. D. Sherwood, Vane rheometry of bentonite gels, Journal of Non-Newtonian Fluid Mechanics, pp. 291-310, 1991
} 
WSRC-TR-2001-00203, Rev. 0

During the yield stress measurem nts using the vane, the measured rotational speed of the rotor behaves as described by Liddel 1 [4]

"It should be pointed out that, although the vane is considered to be in a rate controlled mode, the actual relative motion between the vane and the material varies throughout the measurement. During the elastic deformation the vane is essentially stationary relative to the suspension, so that the rate of stress development can be directly calculated as the product of the applied rotation speed $(\mathrm{rad} / \mathrm{sec})$, the measuring system stiffness $(\mathrm{Nm} / \mathrm{rad})$ and the inverse of the vane constant $\left(\mathrm{m}^{3}\right)$. During viscoelastic flow, the vane rotates slightly relative to the suspension, causing a reduction in the rate of stress development. The rate of stress development during viscoelastic flow is dependent on the material properties as well as the applied rotational speed. When the yield stress is reached the rate of stress development is zero, which corresponds to relative motion between the vane and the material at a rate equal to the applied rotational speed."

The effect of temperature on viscosity was modeled using Arrhenius $\frac{18}{\text { equation shown as }}$ equation [9].

$$
\mu=A_{A r r} \cdot e^{\left(B_{A r r} / T\right)}
$$

Where: $\mu=$ Newtonian viscosity $(\mathrm{mPa}-\mathrm{sec})$

$\mathrm{A}_{\text {Arr }}=$ Arrhenius Fitting Parameter (mPa-sec)

$\mathrm{B}_{\text {Arr }}=$ Arrhenius Fitting Parameter (Kelvin)

$\mathrm{T}=$ Temperature (Kelvin)

18 R. Darby, Chemical Engineering Fluid Mechanics, Marcel Dekker, Inc., pg. 63, 1996 


\section{RESULTS}

\section{AZ-101 Simulant}

Table 4 contains the density, $\mathrm{pH}$ and weight percent solids analyses. Changing the weight \% insoluble solids (IS) concentration did not impact the $\mathrm{pH}$ of the slurry, since the composition of the supernate did not change. The density versus weight $\%$ IS and TS (via the oven results) were fitted to a $2^{\text {nd }}$ order polynomial and shown as equations [10] and [11] respectively. The maximum weight $\%$ IS concentration obtained using the centrifuge was 20.84 weight $\%$, as measured using the microwave. The low weight $\%$ IS concentration from centrifuging could be due to the repulsive forces of the flocculated particles being very high, thus trapping the supernate in the solids structure. The solids analyses performed using the microwave method yielded higher total and insoluble results as compared to the oven method. The difference between the methods is assumed to be due to the waters of hydration and the apparent inability of the microwave to remove waters of hydration. Both results are presented so that comparisons can be made between the same method results.

$$
\begin{gathered}
\rho_{\text {AZ101 }}\left(w t \%_{I S}\right)=0.2339 \cdot\left(w t \%_{I S}\right)^{2}+3.5654 \cdot\left(w t \%_{I S}\right)+1029.9,\left\{\frac{\mathrm{kg}}{\mathrm{m}^{3}}\right\} \\
6.62 \% \leq \cdot w t \%_{I S} \leq 18.55 \%, \quad R^{2}=0.9985 \\
\rho_{\text {AZ101 }}\left(w t \%_{T S}\right)=0.2494 \cdot\left(w t \%_{T S}\right)^{2}+2.661 \cdot\left(w t \%_{T S}\right)+1023.5,\left\{\frac{\mathrm{kg}}{\mathrm{m}^{3}}\right\} \\
8.47 \% \leq \cdot w t \%_{T S} \leq 20.00 \%, \quad R^{2}=0.9989
\end{gathered}
$$

Table 4 Physical and Chemical Data for AZ-101 Simulant

\begin{tabular}{|c|c|c|c|c|c|}
\hline \multirow{2}{*}{$\begin{array}{c}\text { Target wt } \\
\% \text { I.S. }\end{array}$} & \multirow{2}{*}{$\begin{array}{c}\text { Density } \\
\left(\mathrm{kg} / \mathrm{m}^{3}\right)\end{array}$} & \multirow{2}{*}{$\mathrm{pH}$} & \multicolumn{3}{|c|}{$\begin{array}{c}\text { Wt. \% Solids Analysis } \\
\text { Oven / Microwave }\end{array}$} \\
\cline { 4 - 6 } & & & Total & Soluble & Insoluble \\
\hline 7.5 & 1065 & 9.93 & $8.47 / 8.97$ & $1.85 / 1.50$ & $6.62 / 7.47$ \\
\hline 10.0 & 1080 & 10.06 & $10.91 / 11.56$ & $1.71 / 1.46$ & $9.18 / 10.10$ \\
\hline 12.5 & -- & -- & $13.81 /--$ & $1.66 /--$ & $12.15 /--$ \\
\hline 15.0 & 1125 & 10.11 & $15.39 / 16.26$ & $1.63 / 1.38$ & $13.78 / 14.88$ \\
\hline $\begin{array}{c}15.02^{\text {nd }} \\
\text { batch }\end{array}$ & -- & -- & $15.32 /--$ & $1.51 /--$ & $13.81 /--$ \\
\hline 16.0 & --- & -- & $17.03 /--$ & $1.57 /--$ & $15.46 /--$ \\
\hline 17 & -- & -- & $18.07 /--$ & $1.59 /--$ & $16.48 /--$ \\
\hline 18 & -- & -- & $19.22 /--$ & $1.55 /--$ & $17.66 /--$ \\
\hline 19 & -- & -- & $20.25 /--$ & $1.58 /--$ & $18.67 /--$ \\
\hline 20.0 & 1176 & 10.10 & $20.00 / 20.77$ & $1.45 / 1.31$ & $18.55 / 19.47$ \\
\hline \multicolumn{2}{|c|}{ Maximum value via centrifuging } & $--/ 22.16$ & $--/ 1.31$ & $--/ 20.84$ \\
\hline
\end{tabular}


WSRC-TR-2001-00203, Rev. 0

All of the flow curves, unless other wise specified, were obtained using the cone and plate geometry on the Haake RS150 rheometer. Inspection of these curves typically show that as the weight $\%$ IS increases, the slurry becomes more thixotropic. Flow curve measurements could not be obtained for the $323 \mathrm{~K}$ temperature runs for weight $\%$ IS above 15 weight $\%$ target, using the cone to plate geometry due to sample drying. A large peak in the measured stress was observed for all the flow curves at the beginning of the initial up curve measurement. The peak may show that these slurries have a well-defined structure that breaks down after shearing. An alternative explanation for the peak is that the peak is due to slip occurring between the sensor and the sample. Measurements were not made during this study to allow for correction of the data for slip. If the peak value is due to a well-defined structure, then it could potentially be used for engineering purposes, such as startup torque, slope for natural draining, etc.

Table 5 contains the Bingham Plastic parameters fitted to the rheological data on the return or down flow curves shown in FIGURE A - 1, FIGURE A - 2 and FIGURE A - 3 in Appendix A. Only the return curves (down flow curves) were fitted, due to the reasons described in the previous paragraph. Also the up flow curves, especially for the higher insoluble solids content, did not provide a realistic fit to any rheological model. The results in Table 5 show that the yield stress is most impacted by the change in weight \% IS. For a given weight \% IS, the yield stress is greater and the consistency is smaller when comparing the $298 \mathrm{~K}$ data to the $323 \mathrm{~K}$ data. The yield stress as a function of weight \% insoluble solids are shown in Figure 3 and Figure 4 for the $298 \mathrm{~K}$ and $323 \mathrm{~K}$ measurements respectively.

Figure 3 Simulated AZ-101, Yield Stress versus Wt. \% Insoluble Solids, 298 K

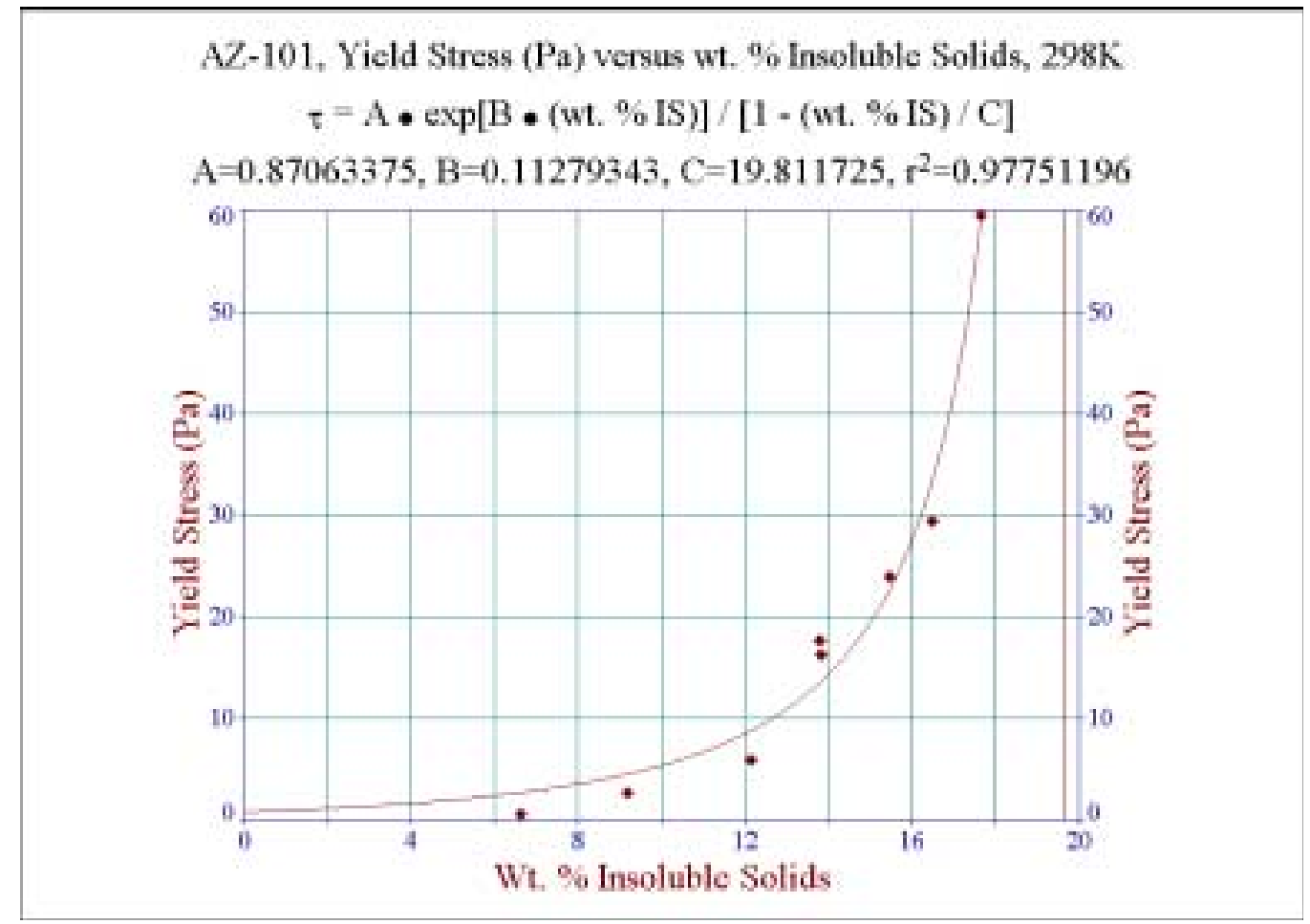


WSRC-TR-2001-00203, Rev. 0

Figure 4 Simulated AZ-101, Yield Stress versus Wt. \% Insoluble Solids, 323 K

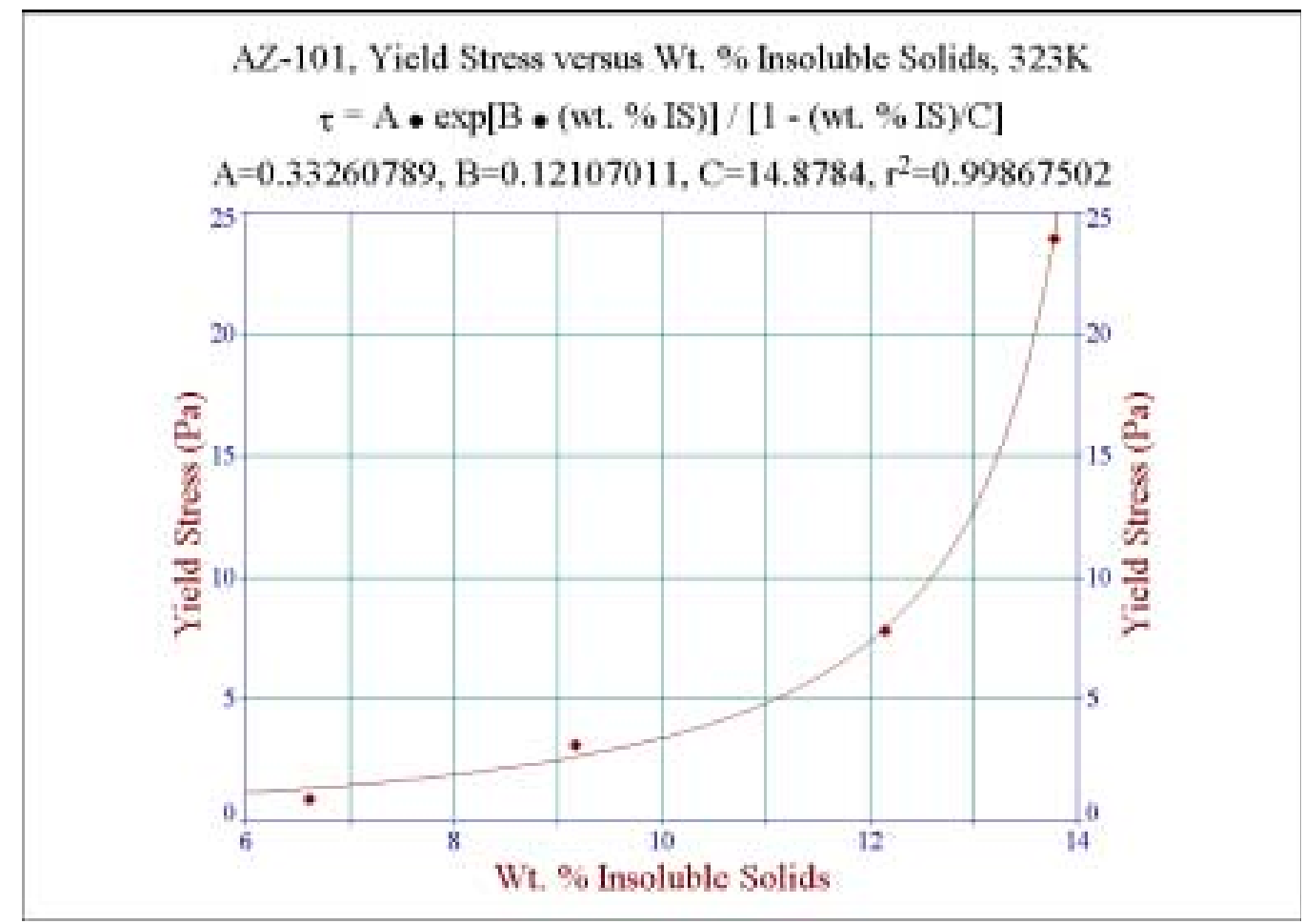

The curves in Figure 3 and Figure 4 were fitted using equation [6] and are shown as equations [12] and [13]. Comparing the maximum weight $\%$ IS parameter $\left(\mathrm{C}_{\max }\right)$, the $323 \mathrm{~K}$ value is smaller, which is most likely due to the limited number of available data points to which the curve was fitted. The $\mathrm{C}_{\max }$ for the $298 \mathrm{~K}$ data is of the same magnitude as the maximum weight $\%$ IS obtained using the centrifuge shown in Table 4, after adjusting the measured microwave result to an oven-based value. The consistency versus wt. \% I.S. curves were not generated, because the consistency seemed to be fairly insensitive to the change in wt. \% I.S., until it reached a much higher wt $\%$ I.S. concentration, where the yield stress had already become large.

$$
\begin{gathered}
\tau_{o, A Z 101}(298 K)=\frac{0.871 \cdot e^{0.1128 \cdot\left(w t \%_{I S}\right)}}{1-\frac{w t \% I S}{19.81}}\{P a\}, 6.62 \% \leq \cdot w t \%_{I S} \leq 18.55 \%, \quad R^{2}=0.9775 \\
\tau_{o, A Z 101}(323 K)=\frac{0.333 \cdot e^{0.1211 \cdot\left(w t \%_{I S}\right)}}{1-\frac{w t \% I S}{14.88}}\{P a\}, 6.62 \% \leq \cdot w t \%_{I S} \leq 13.78 \%, \quad R^{2}=0.9987
\end{gathered}
$$


WSRC-TR-2001-00203, Rev. 0

Table 5 Rheological Properties for AZ-101 Simulant

\begin{tabular}{|c|c|c|c|c|c|c|c|c|}
\hline \multicolumn{2}{|c|}{ Wt. \%Insoluble Solids } & \multicolumn{3}{|c|}{$298 \mathrm{~K}$} & \multicolumn{3}{|c|}{$323 \mathrm{~K}$} & \multirow{2}{*}{$\begin{array}{l}\text { Fitted Shear } \\
\text { rate range } \\
\left(\mathrm{sec}^{-1}\right)\end{array}$} \\
\hline Target & Measured & $\begin{array}{c}\text { Yield } \\
\text { Stress (Pa) }\end{array}$ & $\begin{array}{l}\text { Consistency } \\
(\mathrm{mPa}-\mathrm{sec})\end{array}$ & $\mathrm{R}^{2}$ & $\begin{array}{c}\text { Yield } \\
\text { Stress (Pa) }\end{array}$ & $\begin{array}{c}\text { Consistency } \\
(\mathrm{mPa}-\mathrm{sec})\end{array}$ & $\mathrm{R}^{2}$ & \\
\hline 7.5 & 6.62 & 0.68 & 3.1 & 0.9974 & 0.88 & 1.67 & 0.9974 & $50-700$ \\
\hline 10.0 & 9.18 & 2.75 & 4.3 & 0.9990 & 3.99 & 3.10 & 0.9982 & $100-1000$ \\
\hline 12.5 & 12.15 & 5.97 & 5.1 & 0.9990 & 7.8 & 2.87 & 0.9974 & $\begin{array}{c}100-1000 \\
200-1000\end{array}$ \\
\hline 15.0 & 13.78 & 17.7 & 9.4 & 0.9998 & 23.9 & 5.32 & 0.9872 & $\begin{array}{l}200-1000 \\
400-2000\end{array}$ \\
\hline $\begin{array}{l}15.02^{\text {nd }} \\
\text { batch }\end{array}$ & 13.81 & 16.3 & 7.7 & 0.9996 & -- & -- & -- & $200-1000$ \\
\hline 16.0 & 15.46 & 24.0 & 8.0 & 0.9996 & -- & -- & -- & $200-1000$ \\
\hline 17 & 16.48 & 29.4 & 7.4 & 0.9990 & -- & -- & -- & $200-1000$ \\
\hline 18 & 17.66 & 59.5 & 10.0 & 0.9960 & -- & -- & -- & $200-1000$ \\
\hline 20.0 & 18.55 & 193.2 & 67.2 & 0.9864 & -- & -- & -- & $1000-2000$ \\
\hline
\end{tabular}

The yield stresses in Table 5 represent the return or down flow curves fitted to the Bingham Plastic model. These calculated values were smaller than the peak stress in the up curve, taken during the initial measurement of the up curve. To investigate this peak, a vane was used to measure the yield stress of the $2^{\text {nd }}$ batch of targeted 15 wt. \% I.S. AZ-101 slurry at various rotor speeds. The flow curve for this slurry is shown in FIGURE A - 4 in the Appendix. The vane measurements are shown in FIGURE A - 5 and the maximum measured stress for each curve is shown in Figure 5. The average yield stress of the vane was calculated and a comparison to the measured peak yield stress from the up flow curve shows they are approximately the same. Note this may only be a coincidence that the peak stress from the up curve is approximately the same as that of the vane. The yields stress from the down flow curve in FIGURE A - 4 is $16.25 \mathrm{~Pa}$ and differs greatly from that of the average vane measurement. The fitted flow curve would represent a steady state condition, which would be used for normal operations. It can be concluded that the fitted data in Table 5. as well as all the analyses concerning all the slurries in this study, need to be analyzed using a method in which the flow curve can be corrected, if necessary. This analysis may show that these slurries indeed do have a high yield stress that quickly dissipates under applied shear, in which the vane measured yield stress could be used for startup torque, re-starting flow in a filled pipeline, flushing, or any other engineering application where this yield stress may be of importance. The higher yield stress from the vane measurement could replace the lower curve fitted yield stress. This would be conservative, but it needs further investigation. 
WSRC-TR-2001-00203, Rev. 0

\section{Figure 5 AZ-101, 15 wt. \% IS, $2^{\text {nd }}$ Batch, Yield Stress Using Vane Geometry 298 K}

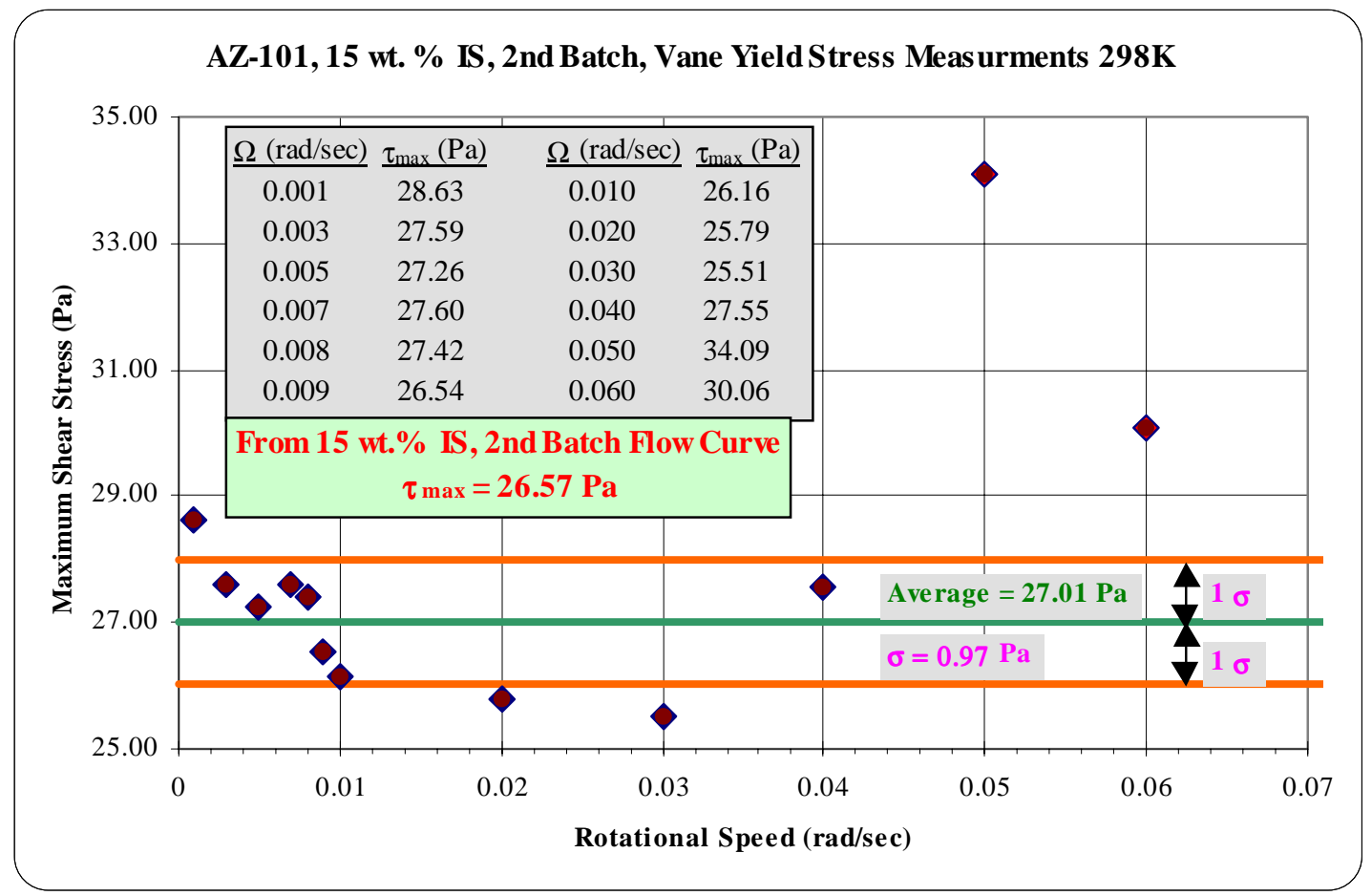

During the yield stress measuremfnts using the vane, the measured rotational sped of the rotor behaved as described by Liddell 16

\section{AZ-102 Sludge Simulant}

Table 6 contains the density, $\mathrm{pH}$ and weight percent solids analyses. Changing the weight \% IS concentration did not impact the $\mathrm{pH}$ of the slurry. This was expected, since the composition of the supernate did not change when targeting the different weight $\%$ IS concentrations. The density versus weight $\%$ IS and TS (via the oven results) were fitted to a $2^{\text {nd }}$ order polynomial and shown as equations [14] and [15] respectively. The maximum weight \% IS concentration obtained using the centrifuge was $26.99 \mathrm{wt}$. \%, as measured using the microwave. This weight $\%$ IS concentration from centrifuging could be due to the repulsive forces of the flocculated particles being very high, thus trapping the supernate in the solids structure. The solids analyses performed using the microwave yielded higher total and insoluble solids as compared to the oven. The AZ-102 simulant was concentrated to a higher I.S. concentration than the AZ-101 simulant.

$$
\begin{gathered}
\rho_{\text {AZ102 }}\left(w t \%_{I S}\right)=0.2876 \cdot\left(w t \%_{I S}\right)^{2}+1.4816 \cdot\left(w t \%_{I S}\right)+1029.4,\left\{\frac{\mathrm{kg}}{\mathrm{m}^{3}}\right\} \\
9.56 \% \leq \cdot w t \%_{I S} \leq 19.63 \%, \quad R^{2}=0.9978
\end{gathered}
$$


WSRC-TR-2001-00203, Rev. 0

SRT-RPP-2001-00051, Rev. 0

TRPT-24590-01-00001

$\rho_{\text {AZ102 }}\left(w t \%_{T S}\right)=0.3005 \cdot\left(w t \%_{T S}\right)^{2}+0.8506 \cdot\left(w t \%_{T S}\right)+1030.7,\left\{\frac{k g}{m^{3}}\right\}$
$10.10 \% \leq \cdot w t \%_{T S} \leq 20.11 \%, \quad R^{2}=0.998$

Table 6 Physical and Chemical Data for AZ-102 Simulant

\begin{tabular}{|c|c|c|c|c|c|}
\hline \multirow{2}{*}{$\begin{array}{c}\text { Target wt } \\
\% \text { I.S. }\end{array}$} & \multirow{2}{*}{$\begin{array}{c}\text { Density } \\
\left(\mathrm{kg} / \mathrm{m}^{3}\right)\end{array}$} & \multirow{2}{*}{$\mathrm{pH}$} & \multicolumn{3}{|c|}{$\begin{array}{c}\text { Wt. \% Solids Analysis } \\
\text { Oven / Microwave }\end{array}$} \\
\cline { 4 - 6 } & & & Total & Soluble & Insoluble \\
\hline 10.0 & 1071 & 11.52 & $10.10 / 10.59$ & $0.54 / 0.52$ & $9.56 / 10.007$ \\
\hline 12.5 & 1085 & 11.50 & $12.42 / 12.82$ & $0.53 / 0.51$ & $11.89 / 12.31$ \\
\hline 13.75 & -- & -- & $13.89 /--$ & $0.53 /--$ & $13.36 /--$ \\
\hline 15.0 & 1114 & 11.57 & $15.11 / 15.57$ & $0.54 / 0.49$ & $14.57 / 15.07$ \\
\hline 17.0 & -- & -- & $16.61 /--$ & $0.52 /--$ & $16.09 /--$ \\
\hline 18.0 & -- & -- & $17.74 /--$ & $0.51 /--$ & $17.23 /--$ \\
\hline 19.0 & -- & -- & $18.59 /--$ & $0.56 /--$ & $18.03 /--$ \\
\hline 20.0 & 1169 & 11.55 & $20.11 / 20.53$ & $0.48 / 0.49$ & $19.63 / 20.06$ \\
\hline 25 & -- & -- & $25.12 /--$ & $0.42 /--$ & $24.70 /--$ \\
\hline \multicolumn{2}{r|}{ Maximum value via centrifuging } & $--/ 27.44$ & $--/ 0.45$ & $--/ 26.99$ \\
\hline
\end{tabular}

Table 7 contains the Bingham Plastic parameters fitted to the rheological data of the return curves shown in FIGURE A - 6, FIGURE A - 7 and FIGURE A - 8 in Appendix A. Inspection of these curves typically shows that as the weight $\%$ IS increases, the slurry became more thixotropic. Flow curve measurements could not be obtained for the $323 \mathrm{~K}$ temperature runs for weight \% IS. above $18 \mathrm{wt}$. \% target, using the cone to plate geometry due to the sample drying. For all the flow curves, other than the lowest weight \% IS measurement, at the beginning of the initial up curve measurement, a large peak in the measured stress was observed. The peak may show that these slurries have a well-defined structure that breaks down after shearing. An alternative explanation for the peak is that the peak is due to slip occurring between the sensor and the sample. Measurements were not made during this study to allow for correction of the data for slip. The results in Table 7 show that of the two Bingham Plastic Parameters, the yield stress was most impacted by the change in weight $\%$ IS, which was consistent with how the AZ101 simulant behaved. For a given weight \% IS, the yield stress was greater at $323 \mathrm{~K}$ and the consistency was smaller at $323 \mathrm{~K}$ when comparing to the $298 \mathrm{~K}$ data. The yield stress as a function of weight \% insoluble solids is shown in Figure 6 and Figure 7 for the $298 \mathrm{~K}$ and $323 \mathrm{~K}$ measurements respectively. 
WSRC-TR-2001-00203, Rev. 0 SRT-RPP-2001-00051, Rev. 0 TRPT-24590-01-00001

Figure 6 Simulated AZ-102, Yield Stress versus Wt. \% Insoluble Solids, 298 K

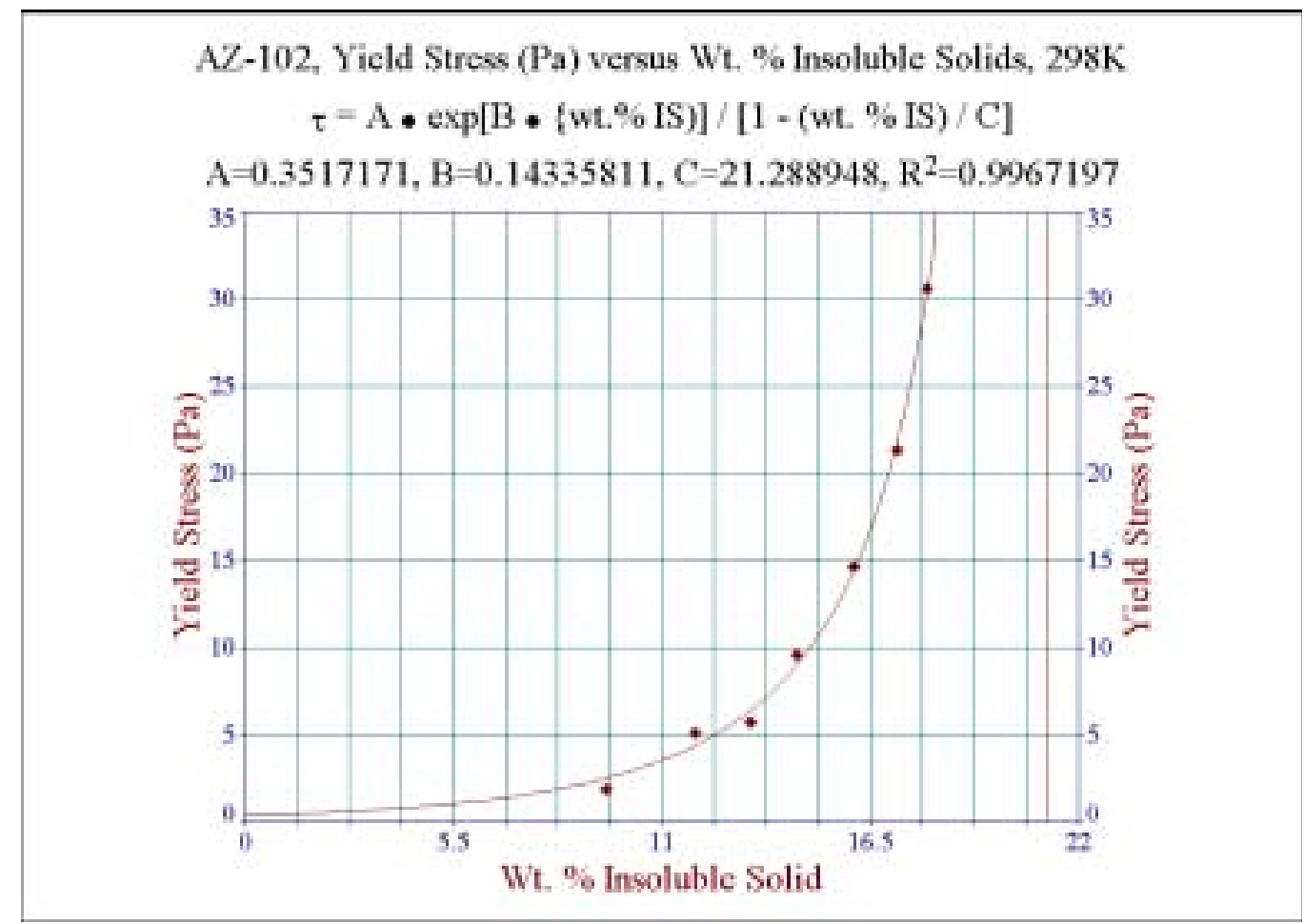

Figure 7 Simulated AZ-102, Yield Stress versus Wt. \% Insoluble Solids, 323 K

AZ-102, Yield Stress Versus Wt. \% Insoluble Solids, 323K

$\tau=\mathrm{A} \bullet \exp [\mathrm{B} \bullet($ wt. \% IS) $] /[1-(w t . \%$ IS) $/ \mathrm{C}]$

$\mathrm{A}=0.33937271, \mathrm{~B}=0.24947468, \mathrm{C}=205.81274, \mathrm{R}^{2}=0.98008455$

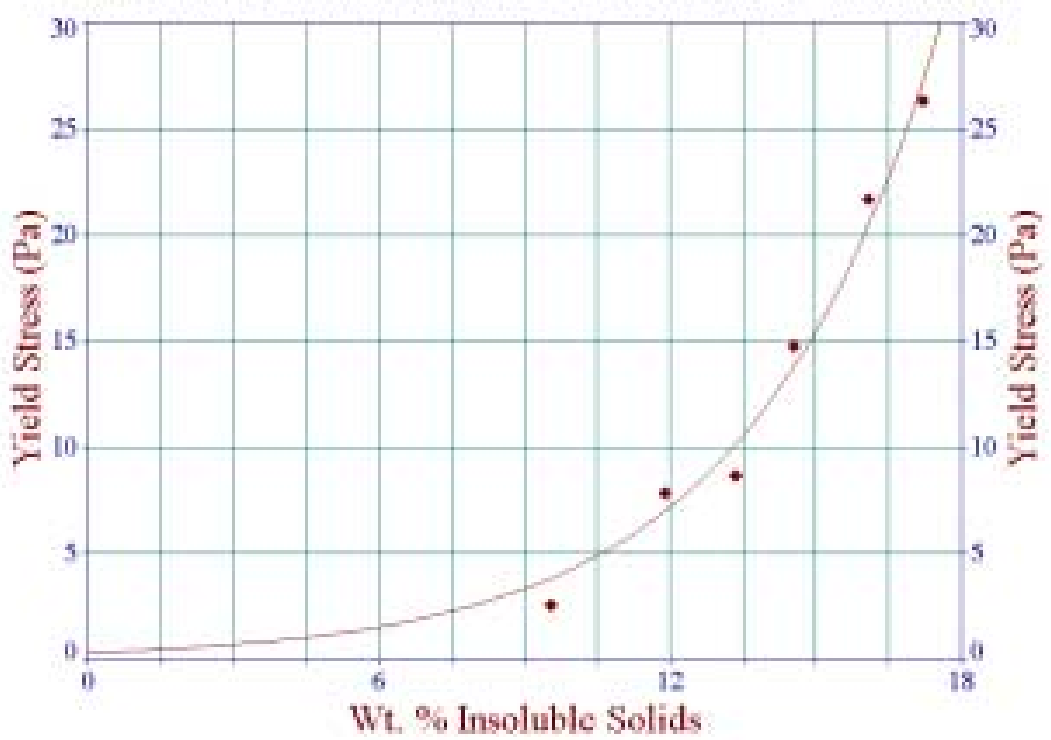


WSRC-TR-2001-00203, Rev. 0

The curves in Figure 6 and Figure 7 were fitted using equation [6] and are shown as equations [16] and [17]. The maximum weight $\%$ IS parameter $\left(\mathrm{C}_{\max }\right)$ for the $323 \mathrm{~K}$ fit was unrealistic, since the maximum total solids can not exceed $100 \%$. The flow curve for the 18 weight $\%$ IS seems to be impacted by drying, as shown in FIGURE A - 7. which could have impacted the calculated yield stress, thus impacting $\mathrm{C}_{\max }$. The $\mathrm{C}_{\max }$ for the $298 \mathrm{~K}$ data was smaller than the maximum weight \% IS shown in Table 6. which was 26.99 weight \% IS (note that this was based on the microwave). The $\mathrm{C}_{\max }$ was very dependent on the 20 weight $\%$ IS yield stress determination, which if over estimated, would cause this calculated value to be smaller. The consistency versus weight \% IS curves were not generated, due to the same reason as specified for the AZ-101 simulant.

$$
\begin{gathered}
\tau_{o, A Z 102}(298 K)=\frac{0.352 \cdot e^{0.1434 \cdot\left(w t \%_{I S}\right)}}{1-\frac{w t \%_{I S}}{21.29}}\{P a\}, 9.56 \% \leq \cdot w t \%_{I S} \leq 19.63 \%, \quad R^{2}=0.9967 \\
\tau_{o, A Z 102}(323 K)=\frac{0.339 \cdot e^{0.2495 \cdot\left(w t \%_{I S}\right)}}{1-\frac{w t \%}{205.81}}\{P a\}, 9.56 \% \leq \cdot w t \%_{I S} \leq 17.23 \%, \quad R^{2}=0.9801 \\
\hline
\end{gathered}
$$

Table 7 Rheological Properties for AZ-102 Simulant

\begin{tabular}{|c|c|c|c|c|c|c|c|c|}
\hline \multicolumn{2}{|c|}{ Wt. \%Insoluble Solids } & \multicolumn{3}{|c|}{$298 \mathrm{~K}$} & \multicolumn{3}{|c|}{$323 \mathrm{~K}$} & $\begin{array}{c}\text { Fitted Shear } \\
\text { rate range } \\
\left(\mathrm{sec}^{-1}\right)\end{array}$ \\
\hline Target & Measured & $\begin{array}{c}\text { Yield } \\
\text { Stress (Pa) }\end{array}$ & $\begin{array}{c}\text { Consistency } \\
(\mathrm{mPa}-\mathrm{sec})\end{array}$ & $\mathrm{R}^{2}$ & $\begin{array}{c}\text { Yield } \\
\text { Stress (Pa) }\end{array}$ & $\begin{array}{c}\text { Consistency } \\
(\mathrm{mPa}-\mathrm{sec})\end{array}$ & $\mathrm{R}^{2}$ & 3.6 \\
\hline 10.0 & 9.56 & 1.85 & 3.6 & 0.9988 & 2.57 & 3.0 & 0.9984 & $200-1000$ \\
\hline 12.5 & 11.89 & 5.09 & 4.5 & 0.9992 & 7.86 & 3.6 & 0.9992 & $200-1000$ \\
\hline 13.75 & 13.36 & 5.71 & 4.9 & 0.9994 & 8.66 & 3.4 & 0.9984 & $200-1000$ \\
\hline 15.0 & 14.57 & 9.61 & 6.1 & 0.9992 & 14.78 & 4.3 & 0.9912 & $200-1000$ \\
\hline 17.0 & 16.09 & 14.64 & 6.0 & 0.9990 & 21.68 & 4.0 & 0.8887 & $\begin{array}{c}200-1000 \\
250-1000\end{array}$ \\
\hline 18.0 & 17.23 & 21.35 & 6.1 & 0.9950 & 26.33 & 25.8 & 0.9930 & $200-1000$ \\
\hline 19.0 & 18.03 & 30.63 & 6.2 & 0.9976 & -- & -- & -- & $400-1000$ \\
\hline 20.0 & 19.63 & 41.00 & 21.5 & 0.9982 & -- & -- & -- & $200-2000$ \\
\hline
\end{tabular}

Rheology measurements on actual AZ-102 sludge have been collected by researchers at the Pacific Northwest National Laboratory. ${ }^{19}$ A comparison of the apparent viscosity at a shear rate of $200 \mathrm{sec}^{-1}$ indicates that the simulant rheology performance is similar to that of the real waste. The comparison of apparent viscosity is shown in Table 8 . Both sets of data show that the viscosity is a strong function of the solids content of the slurries. The relative magnitude of the values is similar considering that the simulant has not experienced either the radiation or thermal aging that is characteristic of actual waste storage.

\footnotetext{
${ }^{19}$ P. R. Bredt, L. K. Jagoda, D. E. Rinehart, Rheological Studies on Pretreated Feed and Melter Feed from C-104 and AZ-102, PNNL13359, WTP-RPT-004, Rev. 0, Pacific Northwest National Laboratory, Richland, WA 99352, January 2001.
} 
WSRC-TR-2001-00203, Rev. 0

SRT-RPP-2001-00051, Rev. 0

TRPT-24590-01-00001

Table 8: Apparent Viscosity Comparison of Simulated and Actual AZ-102 Sludge

\begin{tabular}{|c|c|c|}
\hline \multirow{2}{*}{ Weight \% Total Solids } & \multicolumn{2}{|c|}{ Apparent Viscosity @ 200 s ${ }^{-1}$ (milliPascal-seconds) } \\
\cline { 2 - 3 } & AZ-102 Simulated Sludge & Actual AZ-102 Sludge \\
\hline 25 & - & 1125 \\
\hline 20 & 232 & 163 and 185 \\
\hline 15 & 54 & 110 \\
\hline
\end{tabular}

\section{AN-107 Sr/TRU Precipitate Simulant}

Table 9 contains the density, $\mathrm{pH}$, and weight percent solids analyses. Changing the weight \% IS concentration of the washed simulant did not impact the $\mathrm{pH}$ of the slurry since the composition of the supernate did not change when targeting the different weight $\%$ IS concentrations. The density versus weight $\%$ IS and T.S. (via the oven results) were fitted to a $3^{\text {rd }}$ order polynomial and shown as equations [18] and [19] respectively. The weight \% IS of the washed simulant using the centrifuge was not measured. The density of the unwashed simulant is approximately $30 \%$ greater than the final washed simulant when measured at 15 weight $\%$ IS since the total solids in the unwashed simulant was 40.92 weight $\%$ as compared to 17.65 weight $\%$ of the washed simulant.

$$
\begin{gathered}
\rho_{\text {washedSr/TRU }}\left(w t \%_{I S}\right)=0.0389 \cdot\left(w t \%_{I S}\right)^{3}-1.168 \cdot\left(w t \%_{I S}\right)^{2}+12.735 \cdot\left(w t \%_{I S}\right)+10255,\left\{\frac{\mathrm{kg}}{\mathrm{m}^{3}}\right\} \\
10.03 \% \leq \cdot w t \%_{I S} \leq 24.69 \%, \quad R^{2}=1.0
\end{gathered}
$$

$$
\begin{gathered}
\rho_{\text {washedSr/TRU }}\left(w^{*} \%_{T S}\right)=0.0402 \cdot\left(w t \%_{T S}\right)^{3}-1.4767 \cdot\left(w t \%_{T S}\right)^{2}+19.062 \cdot\left(w t \%_{T S}\right)+999.2,\left\{\frac{k g}{m^{3}}\right\} \\
12.32 \% \leq \cdot w t \%_{T S} \leq 26.86 \%, R^{2}=1.0
\end{gathered}
$$

Table 9 Physical and Chemical Data for AN-107, Sr/TRU Precipitated Simulated Sludge

\begin{tabular}{|c|c|c|c|c|c|}
\hline \multirow{2}{*}{ Target wt \% I.S. } & \multirow{2}{*}{$\begin{array}{c}\text { Density } \\
\left(\mathrm{kg} / \mathrm{m}^{3}\right)\end{array}$} & \multirow{2}{*}{$\mathrm{pH}$} & \multicolumn{3}{|c|}{ Wt. \% Solids Analysis } \\
\cline { 4 - 6 } & & & Total & Soluble & Insoluble \\
\cline { 4 - 6 } & 1085 & 10.05 & $12.32 / 12.65$ & $2.28 / 2.43$ & $10.03 / 10.23$ \\
\hline 10.0 & 1093 & 9.91 & $16.78 / 17.65$ & $2.36 / 2.29$ & $14.42 / 15.37$ \\
\hline 15.0 & 1452 & -- & $--/ 40.92$ & $--/ 25.14$ & $--/ 15.77$ \\
\hline 15.0 unwashed & 1117 & -- & $--/ 20.72$ & $--/ 2.20$ & $--/ 18.53$ \\
\hline $\begin{array}{c}\text { Initial } \\
\text { Washed/sheared }\end{array}$ & -- & -- & $18.77 /--$ & $2.15 /--$ & $16.62 /--$ \\
\hline 18.33 & 1129 & 9.80 & $21.80 / 22.52$ & $2.25 / 2.15$ & $19.55 / 20.37$ \\
\hline 20.0 & -- & -- & $23.2 /--$ & $2.05 /--$ & $21.15 /--$ \\
\hline 23.33 & 1224 & 9.80 & $26.86 / 27.32$ & $2.17 / 2.02$ & $24.69 / 25.30$ \\
\hline 25.0 & & & &
\end{tabular}


WSRC-TR-2001-00203, Rev. 0

Figure 8 shows the flow curves for the 15 weight \% unwashed AN-107 Sr/TRU measured at 298 $\mathrm{K}$ and $323 \mathrm{~K}$ using the M5/RV20 rheometer with the MV1 concentric cylinder sensor. The measurement were taken with a linear ramp time up of 7 minutes, 2 minutes hold at $1000 \mathrm{~s}^{-1}$, and a linear ramp down time of 7 minutes. There seems to be little difference in the calculated yields stress, using equation [5]. The $298 \mathrm{~K}$ consistency is thicker than the $323 \mathrm{~K}$ consistency, as expected due to the increase in temperature.

Figure 8 Fifteen wt. \% I.S. Unwashed AN-107 Sr/TRU Flow Curves

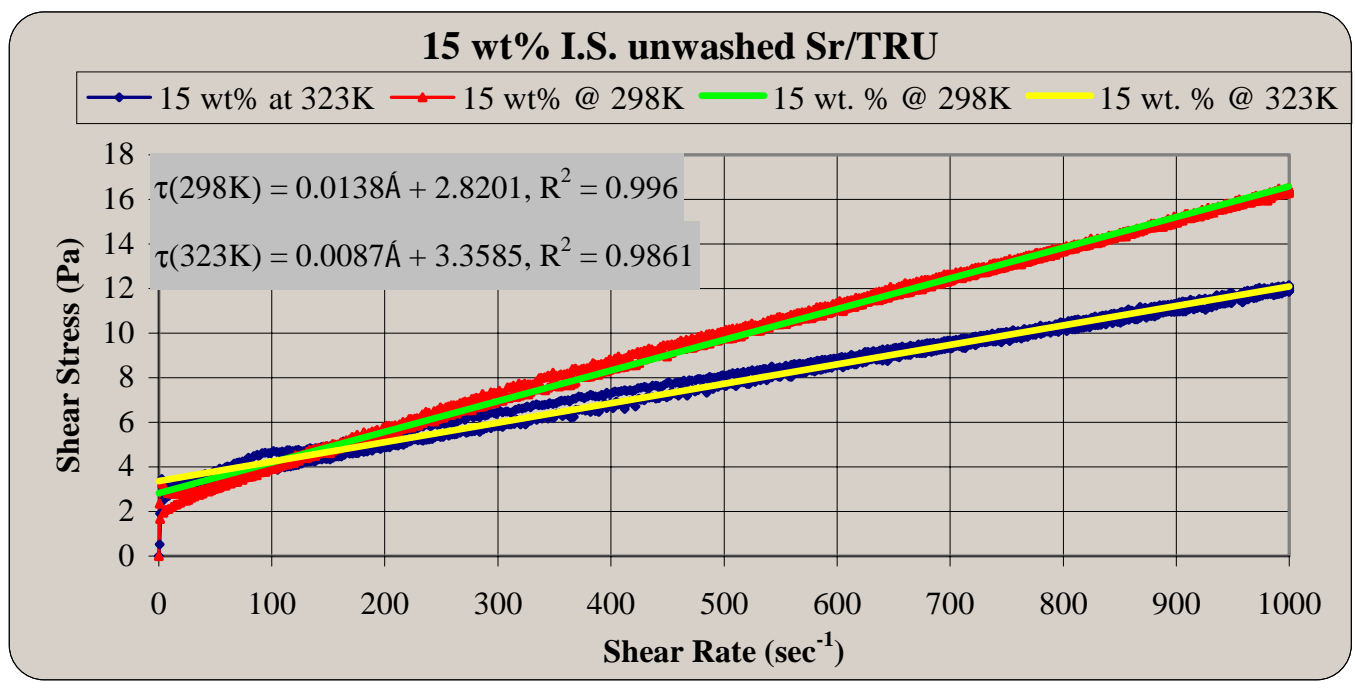

Table 10 contains the Bingham Plastic parameters fitted to the rheological data of the return curves of the washed Sr/TRU precipitate shown in FIGURE A - 9 and FIGURE A - 10 in Appendix A. All of the flow curves for the washed Sr/TRU precipitate were taken using the RS150 rheometer using cone and plate geometry. Inspection of FIGURE A - 9 shows that the flow curves exhibit little thixotropic behavior until the insoluble solids loading was 25 weight $\%$. Flow curve measurements could not be obtained for the $323 \mathrm{~K}$ temperature runs for weight $\%$ IS above 20 weight $\%$ IS, using the cone to plate geometry due to the sample drying. A large peak in the measured stress was observed at the beginning of the initial up curve measurement for all the flow curves, other than the two lowest weight \% IS measurements. The peak could show that these slurries have a well-defined structure that breaks down after shearing or that slip was occurring between the cone and the fluid. The results in Table 10 show that the yield stress is most impacted by the change in weight \% IS, which was consistent with how the AZ-101 and AZ-102 sludge simulants behaved. For a given weight \% IS, the yield stress was greater and the consistency was smaller when comparing the $298 \mathrm{~K}$ data to the $323 \mathrm{~K}$ data, exhibiting the same trends observed with the AZ-101 and AZ-102 slurries. The yield stress as a function of wt. \% insoluble solids are shown in Figure 9 and Figure 10 for the $298 \mathrm{~K}$ and $323 \mathrm{~K}$ measurements respectively. 
WSRC-TR-2001-00203, Rev. 0

Figure 9 Simulated AN-107 Sr/TRU Prec/washed, Yield Stress vs. Wt. \% IS, 298 K

AN-107 SrTRU Precipitate/Washed, Yield Stress Versus Wt. \% 1S, 298K

$\tau=\mathrm{A} \bullet \exp [\mathrm{B} \bullet($ wt. \% IS) $] /[1-($ wt. \% IS) $/ \mathrm{C}]$

$\mathrm{A}=0.11510112, \mathrm{~B}=0.18080035, \mathrm{C}=29.586092, \mathrm{R}^{2}=0.99600776$

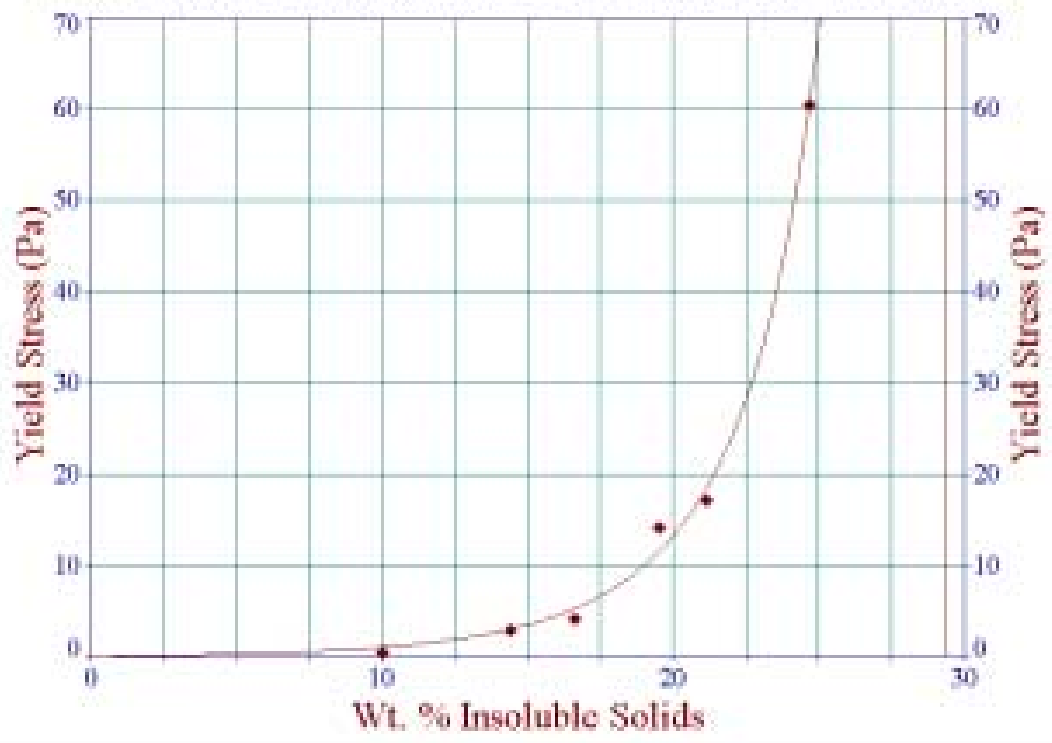

Figure 10 Simulated AN-107 Sr/TRU Prec/washed, Yield Stress vs. Wt. \% IS, 323 K

AN-107 Sr/TRU Precipitate/Washed, Yield Stress Versus Wt. \% IS, 323K

$$
\tau^{-A} \cdot \exp [\mathrm{B} \bullet(\text { wt. \% IS)] }[1-(\text { wt. \% IS }) / C)
$$

$\mathrm{A}=0.17723566, \mathrm{~B}=0.1136217, \mathrm{C}=22.102039, \mathrm{r}^{2}=0.97109005$

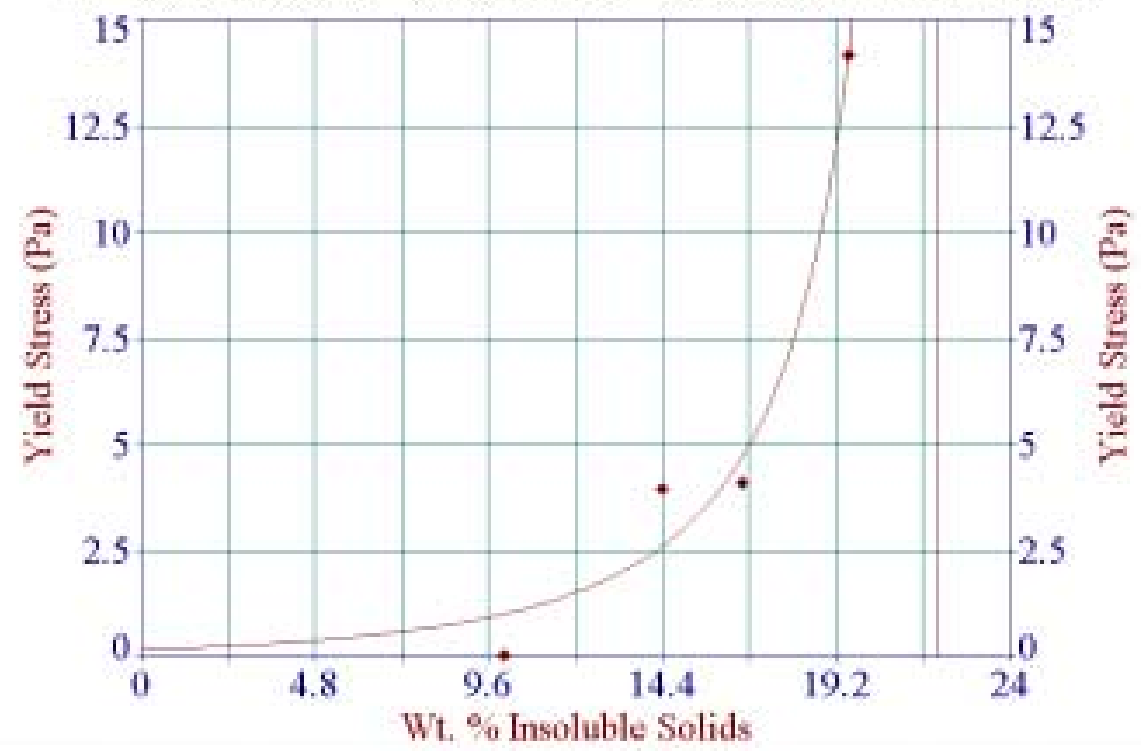

The curves in Figure 9 and Figure 10 were fitted using equation [6] and are shown as equations [20] and [21]. The $\mathrm{C}_{\max }$ for the $298 \mathrm{~K}$ data is larger than the $\mathrm{C}_{\max }$ for the $323 \mathrm{~K}$ data. This was 
WSRC-TR-2001-00203, Rev. 0

consistent with the AZ-101 and AZ-102 results when comparing the $323 \mathrm{~K}$ to the $298 \mathrm{~K} \mathrm{C}_{\max }$ values. The $\mathrm{C}_{\max }$ at $298 \mathrm{~K}$ can not be compared to any physical measurement, but seems to be reasonable in determining the maximum concentration. The consistency versus weight $\%$ IS curves were not generated, due to the same reason as specified for the AZ-101 simulant.

Because different measuring heads (due to different instruments) were used to measure the rheological properties of the 15 weight \% unwashed and washed Sr/TRU slurries, they technically cannot be compared, until they have been corrected for non-Newtonian behavior and slip. However, the following comparison is based on the assumption that the flow curves are comparable. The 15 weight \% IS unwashed Sr/TRU shown in Figure 8, when compared to the washed 15 weight $\%$ IS results in Table 10. show that the yield stresses are about the same. The consistency of the unwashed Sr/TRU is approximately 3 times thicker than the washed 15 weight $\%$ IS since the total solids of the unwashed is much greater than the washed.

$$
\begin{gathered}
\tau_{o, \text { washedSr/TRU }}(298 K)=\frac{0.115 \cdot e^{0.1808 \cdot\left(w t \%_{I S}\right)}}{1-\frac{w t \% I S}{29.59}}\{P a\}, 10.03 \% \leq \cdot w t \% I S \leq 24.69 \%, R^{2}=0.9960 \text { [20] } \\
\tau_{o, \text { washedSr/TRU }}(323 K)=\frac{0.177 \cdot e^{0.1136 \cdot\left(w t \%_{I S}\right)}}{1-\frac{w t \% I S}{22.10}}\{P a\}, 10.03 \% \leq \cdot w t \% I S \leq 19.55 \%, \quad R^{2}=0.9711 \text { [21] }
\end{gathered}
$$

\begin{tabular}{|c|c|c|c|c|c|c|c|c|}
\hline \multicolumn{2}{|c|}{ Wt. \%Insoluble Solids } & \multicolumn{3}{|c|}{$298 \mathrm{~K}$} & \multicolumn{3}{|c|}{$323 \mathrm{~K}$} & \multirow{2}{*}{$\begin{array}{l}\text { Fitted Shear } \\
\text { rate range } \\
\left(\sec ^{-1}\right)\end{array}$} \\
\hline Target & Measured & $\begin{array}{c}\text { Yield } \\
\text { Stress }(\mathrm{Pa})\end{array}$ & $\begin{array}{l}\text { Consistency } \\
(\mathrm{mPa}-\mathrm{sec})\end{array}$ & $\mathrm{R}^{2}$ & $\begin{array}{c}\text { Yield } \\
\text { Stress }(\mathrm{Pa})\end{array}$ & $\begin{array}{c}\text { Consistency } \\
(\mathrm{mPa}-\mathrm{sec})\end{array}$ & $\mathrm{R}^{2}$ & \\
\hline 10.0 & 10.03 & 0.52 & 2.9 & 0.9970 & 0.03 & 1.8 & 0.9401 & $\begin{array}{c}100-700 \\
100-1000 \\
\end{array}$ \\
\hline 15.0 & 14.42 & 2.94 & 4.8 & 0.9972 & 3.97 & 3.3 & 0.9843 & $100-1000$ \\
\hline 18.33 & 16.62 & 4.10 & 4.8 & 0.9986 & 5.63 & 3.5 & 0.9988 & $200-1000$ \\
\hline 20.0 & 19.55 & 14.18 & 7.5 & 0.9998 & 20.93 & 5.5 & 0.9876 & $\begin{array}{l}200-1000 \\
900-2000\end{array}$ \\
\hline 23.33 & 21.15 & 17.21 & 7.9 & 0.9990 & -- & -- & -- & $200-1000$ \\
\hline 25.0 & 24.69 & 60.44 & 13.7 & 0.9996 & -- & -- & -- & $200-1000$ \\
\hline
\end{tabular}

Table 10 Rheological Properties of washed AN-107, Sr/TRU Precipitate

Figure 11 shows the rheological effect shearing has on the washed Sr/TRU precipitate as measured using the M5/RV20 rheometer. The measurements were taken with a linear ramp time up of 7 minutes, 2 minutes hold at $1000 \mathrm{~s}^{-1}$, and a linear ramp down time of 7 minutes. The equipment used to shear this slurry is described in the Simulant Preparation, AZ-101 sludge simulant section in Appendix B and the time of shearing is the Sr/TRU section of Appendix B. The particle size distributions of the washed and washed $\&$ sheared slurries are shown in FIGURE A - 23 and FIGURE A - 24 respectively. These figures show that the particle size distribution becomes narrower in the direction of smaller particle size and the volume average particle size decreases after shearing was completed as reported in Table B- 22 in Appendix B. This is consistent with the results shown in Figure 11. The washed slurry is rheologically thicker (specifically a higher yield stress) than the washed \& sheared slurry. This could be due to the 
WSRC-TR-2001-00203, Rev. 0

SRT-RPP-2001-00051, Rev. 0

TRPT-24590-01-00001

larger flocculated (and most likely non-spherical in shape) particles, which when placed under a shear, require more energy to orient the particles in the direction of flow. The shearing, which reduced the particle size, could have also made the particles more consistent in shape, thus reducing the yield stress. Shearing did not seem to affect the consistency of the slurry. Both slurries have thixotropic characteristics, with the washed slurry being more thixotropic.

Figure 11 Rheological Shear Effects Of Washed Sr/TRU Precipitate

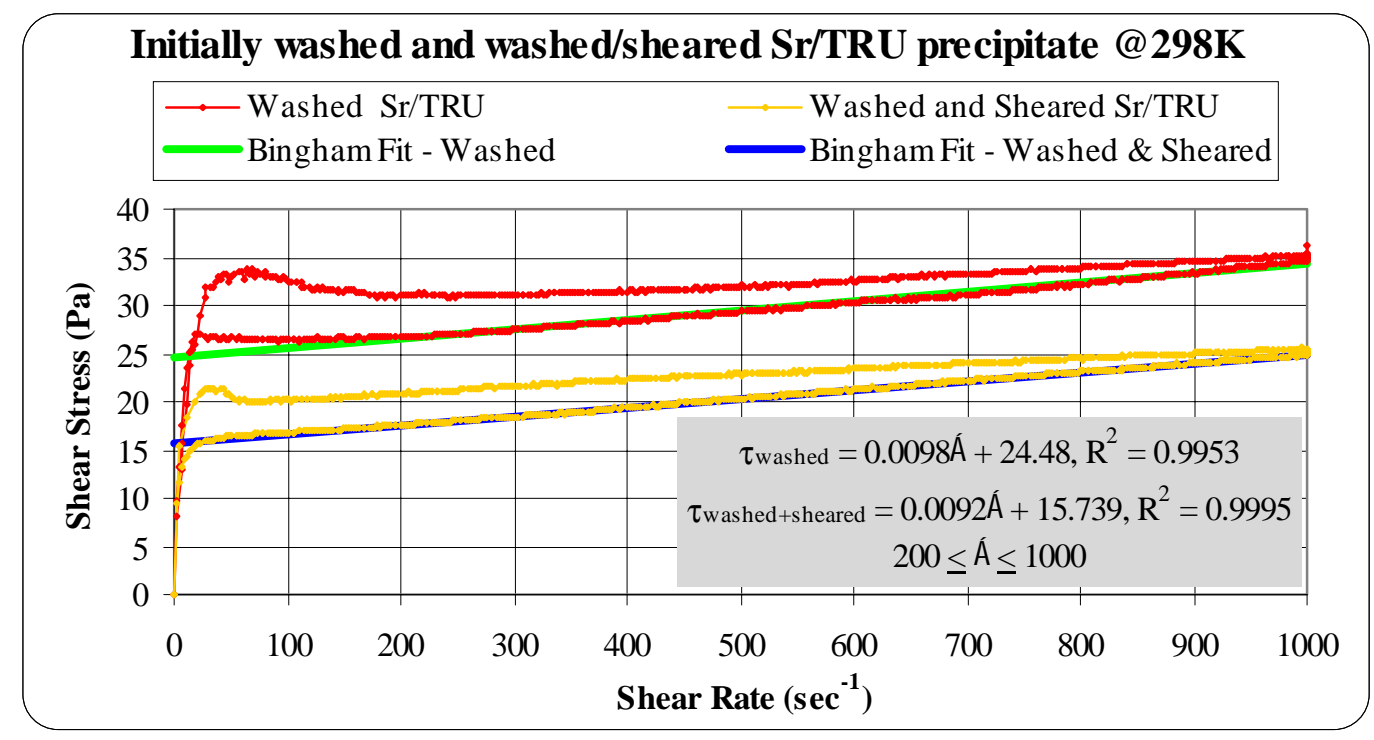

\section{AZ-102 Cs/Tc Eluate Simulant}

The density, $\mathrm{pH}$ and solids analyses are shown in Table 11 for the concentrated blended eluate. There was a slight amount of insoluble solids in the simulant. FIGURE A - 11 in Appendix A contains the individual flow curves ranging between $293 \mathrm{~K}$ to $353 \mathrm{~K}$ obtained using the RS150 rheometer. All the flow curves in FIGURE A - 11 are Newtonian. The $353 \mathrm{~K}$ flow curve, the highest measured temperature, seems to be affected by drying and is questionable, but is still presented and used. The viscosity data from FIGURE A - 11 is shown in Figure 12 and fitted to Arrhenius equation, equation [9], which is located on the figure itself. The data seem to fit well to the Arrhenius equation.

Table 11 Physical and Chemical Data for AZ-102 Cs/Tc Eluate

\begin{tabular}{|c|c|c|c|}
\cline { 3 - 4 } \multicolumn{2}{c|}{} & \multicolumn{2}{c|}{ wt \% Solids Analysis - Oven } \\
\hline Density $\left(\mathrm{kg} / \mathrm{m}^{3}\right)$ & $\mathrm{pH}$ & Total & Insoluble \\
\hline 1110 & 8.72 & 19.45 & 0.61 \\
\hline
\end{tabular}


Figure 12 AZ102 Eluate Viscosity Versus Temperature Data - Curve

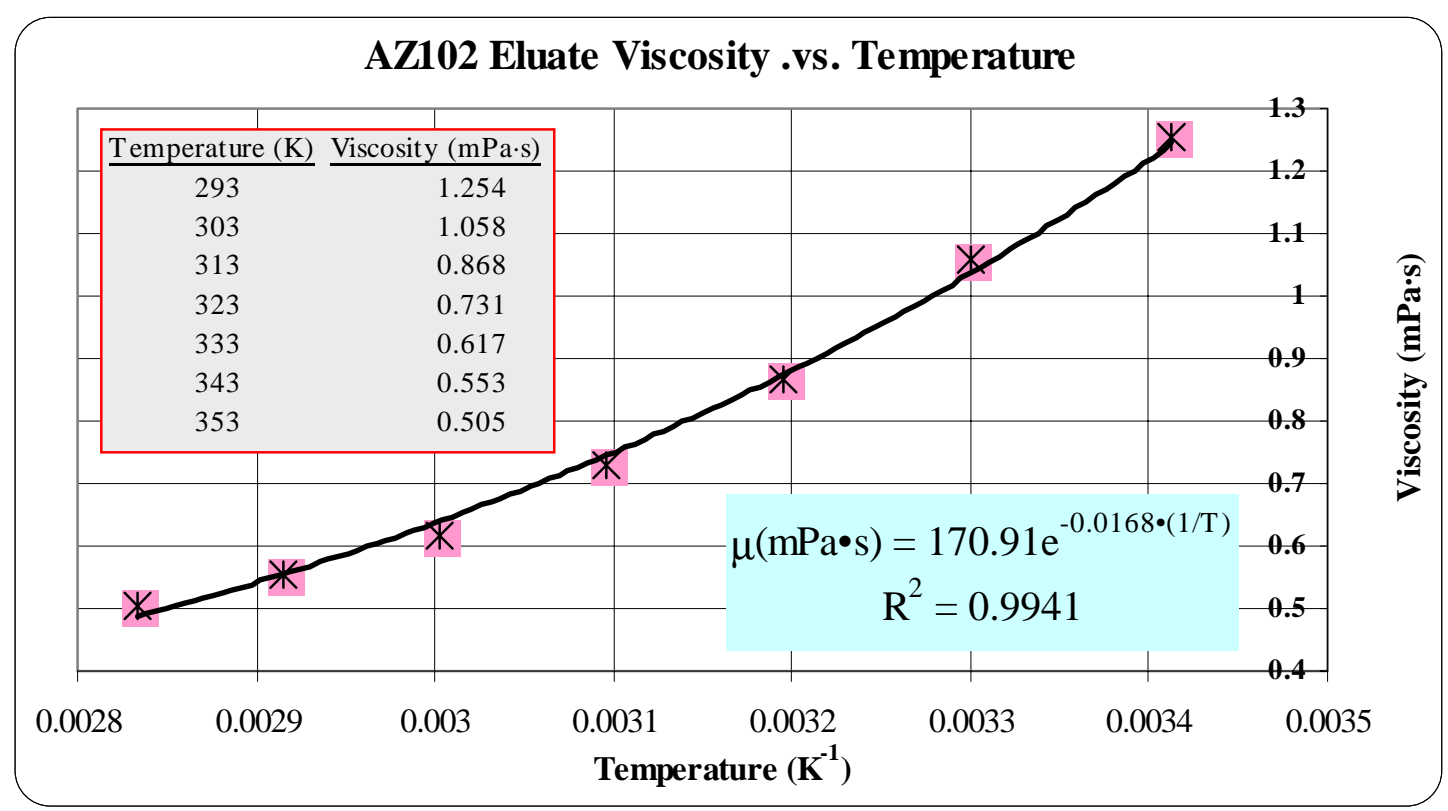

The heat capacity of the eluate was measured between $290 \mathrm{~K}$ to $360 \mathrm{~K}$ and is shown in Figure 13 and the data is shown in Table 12. A $2^{\text {nd }}$ order polynomial was fitted to all the data, except for the first two data points. ${ }^{20}$ These two points are near the instrument start up temperature and are highly uncertain. The $2^{\text {nd }}$ order polynomial curve described above and is shown in Figure 13 is recommended for calculating the heat capacity of the first two data points.

Table 12 Heat Capacity Data for AZ-102 Eluate Simulant

\begin{tabular}{|c|c|c|c|}
\hline Temp $(\mathrm{K})$ & $\mathrm{cP}(\mathrm{J} / \mathrm{gK})$ & $\mathrm{Temp}(\mathrm{K})$ & $\mathrm{cP}(\mathrm{J} / \mathrm{gK})$ \\
\hline 290 & 1.934 & 330 & 2.109 \\
\hline 298 & 1.988 & 340 & 2.133 \\
\hline 300 & 2.016 & 350 & 2.155 \\
\hline 310 & 2.061 & 360 & 2.177 \\
\hline 320 & 2.086 & & \\
\hline
\end{tabular}

${ }^{20}$ F. Fondeur, email, "Heat Capacity Measurement”, 12/13/00 


\section{Figure 13 AZ-102 Eluate Heat Capacity Versus Temperature}

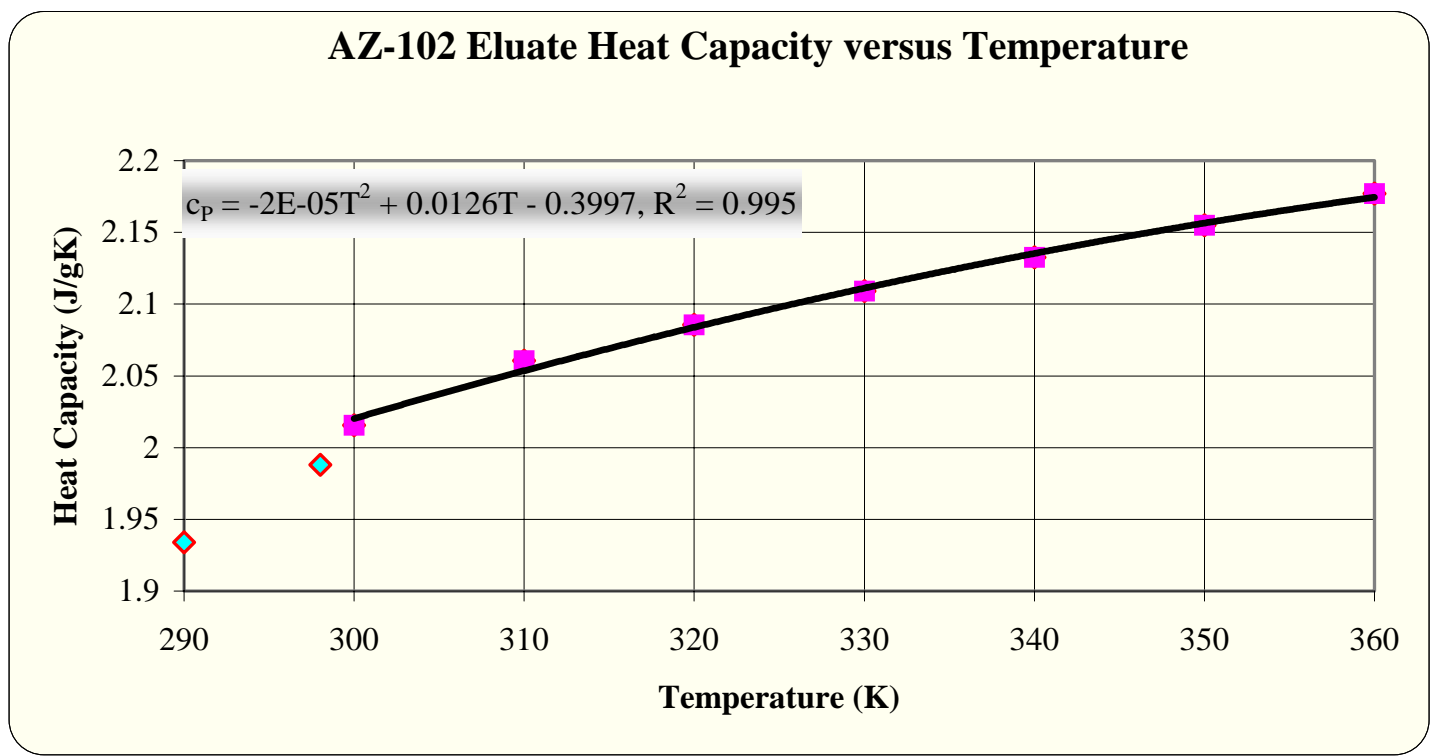

\section{AZ-101 + Blended Compositions}

The $\mathrm{pH}$, solids analyses, and rheological results are shown in Table 13 for the various AZ-101 test mixtures. Particle size distribution was measured for the AZ-101 blends and are shown in Appendix A. The blended compositions have little effect on the $\mathrm{pH}$, which is consistent with blending three nonreactive mixtures whose initial $\mathrm{pH}$ is similar. Comparing these values to the baseline data in Table 5 shows that the yield stress and consistency decreased when the added $\mathrm{Cs} / \mathrm{Tc}$ eluate and $\mathrm{Sr} / \mathrm{TRU}$ precipitate diluted the base slurry as shown in test mixtures $1.4,1.5$, ADD-1, and ADD-2. The opposite was true, when the thicker Sr/TRU precipitate was added to text mixture 1.3.

Table 13 Physical, Chemical and Rheological Data for AZ-101, Eluate, and Sr/TRU blends

\begin{tabular}{|c|c|c|c|c|c|c|c|c||}
\hline $\begin{array}{c}\text { Test } \\
\text { Mixture }\end{array}$ & $\mathrm{pH}$ & \multicolumn{2}{|c|}{$\begin{array}{c}\text { Wt. \% Solids } \\
\text { Analysis Oven } \\
\text { Method } \\
\text { Total }\end{array}$} & $\begin{array}{c}\text { Density } \\
\left(\mathrm{kg} / \mathrm{m}^{3}\right)\end{array}$ & $\begin{array}{c}\text { Yield } \\
\text { Stress (Pa) }\end{array}$ & $\begin{array}{c}\text { Consistency } \\
(\mathrm{mPa}-\mathrm{sec})\end{array}$ & $\mathrm{R}^{2}$ & $\begin{array}{c}\text { Fitted Shear } \\
\text { rate range } \\
\left(\mathrm{sec}^{-1}\right)\end{array}$ \\
\hline 1.3 & 9.92 & 20.21 & 18.64 & 1173.4 & 61.99 & 12.7 & 0.9984 & $200-1000$ \\
\hline 1.4 & 10.14 & 15.72 & 14.12 & 1107.1 & 11.98 & 7.5 & 0.9990 & $200-1000$ \\
\hline 1.5 & 10.17 & 16.49 & 14.95 & 1130.1 & 18.64 & 9.1 & 0.9984 & $200-1000$ \\
\hline ADD-1 & 9.92 & 9.01 & 7.21 & 1064.8 & 0.52 & 3.0 & 0.9974 & $100-800$ \\
\hline ADD-2 & 9.98 & 11.35 & 9.54 & 1087.2 & 2.07 & 4.2 & 0.9960 & $200-800$ \\
\hline
\end{tabular}

\section{AZ-102 + Blended Compositions}

The $\mathrm{pH}$, solids analyses, and rheological results are shown in Table 14 for the various AZ-102 test mixtures. Particle size distributions were measured for the AZ-102 blends and shown in Appendix A. The blended compositions had little effect on $\mathrm{pH}$, which is consistent with 
WSRC-TR-2001-00203, Rev. 0

blending three nonreactive mixtures whose initial $\mathrm{pH}$ was similar. Comparing these values to the baseline data in Table 7 shows that the yield stress and consistency increased when the added $\mathrm{Cs} / \mathrm{Tc}$ eluate and Sr/TRU precipitate thickened the base slurry as shown in test mixtures 2.4, 2.5, ADD-3, and ADD-4. Comparing test mixtures 2.3 and 2.9 to the baseline data in Table 7 shows that the results are different in behavior. This could be due to the applied shear rate range for the base case was $0-2000 \mathrm{sec}^{-1}$ as compared to $0-1000 \mathrm{sec}^{-1}$ for test mixtures 2.3 and 2.9. Comparing test mixtures 2.3 to 2.9 show that it's behaves as expected, where 2.9 is thinner than 2.3 .

Table 14 Physical, Chemical and Rheological Data for AZ-102, Eluate, and Sr/TRU blends

\begin{tabular}{|c|c|c|c|c|c|c|c|c|}
\hline \hline $\begin{array}{c}\text { Test } \\
\text { Mixture }\end{array}$ & $\mathrm{pH}$ & \multicolumn{2}{|c|}{$\begin{array}{c}\text { Wt. \% Solids } \\
\text { Analysis Oven } \\
\text { Method } \\
\text { Total }\end{array}$} & $\begin{array}{c}\text { Density } \\
\left(\mathrm{kg} / \mathrm{m}^{3}\right)\end{array}$ & $\begin{array}{c}\text { Yield } \\
\text { Stress (Pa) }\end{array}$ & $\begin{array}{c}\text { Consistency } \\
(\mathrm{mPa}-\mathrm{sec})\end{array}$ & $\mathrm{R}^{2}$ & $\begin{array}{c}\text { Fitted Shear } \\
\text { rate range } \\
\left(\mathrm{sec}^{-1}\right)\end{array}$ \\
\hline 2.3 & 11.24 & 20.15 & 19.12 & 1171.6 & 59.46 & 9.4 & 0.9946 & $200-1000$ \\
\hline 2.4 & 11.16 & 15.19 & 14.22 & 1111.7 & 11.29 & 6.2 & 0.9984 & $100-1000$ \\
\hline 2.5 & 11.14 & 15.66 & 14.74 & 1109.4 & 13.16 & 7.2 & 0.9972 & $200-1000$ \\
\hline 2.9 & 11.41 & 19.93 & 19.05 & 1172.2 & 54.22 & 8.1 & 0.9898 & $300-1000$ \\
\hline ADD-3 & 11.18 & 10.54 & 9.69 & 1078.8 & 2.78 & 3.6 & 0.9988 & $100-1000$ \\
\hline ADD-4 & 11.10 & 12.75 & 11.88 & 1052.3 & 6.58 & 4.1 & 0.9984 & $100-1000$ \\
\hline
\end{tabular}

\section{Effect of pH Adjustment}

The goal of the $\mathrm{pH}$ adjustment experiment was to determine if adjusting the $\mathrm{pH}$ with a suitable acid would allow the blend to be produced at higher total solids loading by modifying the blend rheological properties. Test mixtures $1.4,1.5,2.3$ and 2.5 were adjusted with nitric acid to produce blends with $\mathrm{pH}$ values of nominally 9,7 and 5. Nitric acid was chosen for the $\mathrm{pH}$ adjustment as having potentially the least impact on glass properties compared to the other mineral acids, which have either undesirable glass properties or poor corrosion characteristics. A reducing acid (organic acid) could also have been used but other potential problems can occur. The data from the $\mathrm{pH}$ adjustment is shown in Table 15 Results for the $\mathrm{pH} 9$ and 7 samples for weight percent solids and density were not obtained because of the small amount of sample available and the need to preserve as much sample as possible for the rheology measurements. The yield stress values were based on fitting a Bingham model to the up flow curve since the curves generally fit well from 100 to $1000 \mathrm{sec}^{-1}$.

During the $\mathrm{pH}$ adjustment process, it was noted that gas evolution occurred and that the blend flow properties were visibly changing. The gas evolution was presumed to be due to the conversion of carbonate to $\mathrm{CO}_{2}$ by the nitric acid. Due to this reaction, a replacement of each carbonate anion is made with two nitrate anions and a water molecule. The net result would be an increase in total solids due to the mass of two nitrate anions for each carbonate anion converted to $\mathrm{CO}_{2}$. The increase in total solids was observed for all four of the test mixtures when comparing the initial $\mathrm{pH}$ total solids to the $\mathrm{pH} 5$ total solids as shown in Table 15. Since many of the metal carbonates are insoluble or have limited solubility and all of the metal nitrates are soluble, an increase in the soluble solids and a decrease in the insoluble solids would also be expected. The results in Table 15 also demonstrate this change in slurry physical properties. 
WSRC-TR-2001-00203, Rev. 0

SRT-RPP-2001-00051, Rev. 0

TRPT-24590-01-00001

The observation during mixing of the $\mathrm{pH}$ adjusted test blends that the flow properties of the test blends appeared to be changing was confirmed by the rheology measurements as shown in Table 15 .

\section{Table 15 Physical and Rheological Data for pH-Adjusted AZ-101 and AZ-102 Blends at $298 \mathrm{~K}$}

\begin{tabular}{|c|c|c|c|c|c|c|c|c|}
\hline \hline $\begin{array}{c}\text { Test } \\
\text { Mixture }\end{array}$ & $\mathrm{pH}$ & \multicolumn{2}{|c|}{$\begin{array}{c}\text { Wt. \% Solids } \\
\text { Analysis Oven } \\
\text { Method } \\
\text { Total }\end{array}$} & $\begin{array}{c}\text { Density } \\
\left(\mathrm{kg} / \mathrm{m}^{3}\right)\end{array}$ & $\begin{array}{c}\text { Yield } \\
\text { Stress (Pa) }\end{array}$ & $\begin{array}{c}\text { Consistency } \\
(\mathrm{mPa}-\mathrm{sec})\end{array}$ & $\mathrm{R}^{2}$ & $\begin{array}{c}\text { Fitted Shear } \\
\text { rate range } \\
\left(\mathrm{sec}^{-1}\right)\end{array}$ \\
\hline 1.4 & 10.14 & 15.72 & 14.12 & 1107.1 & 11.49 & 7.6 & 0.9986 & $200-1000$ \\
\hline 1.4 & 8.16 & & & & 20.04 & 6.8 & 0.9952 & $100-1000$ \\
\hline 1.4 & 7.01 & & & & 36.11 & 10.0 & 0.9908 & $200-1000$ \\
\hline 1.4 & 5.09 & 16.64 & 11.68 & 1134.6 & 27.44 & 8.9 & 0.9946 & $200-1000$ \\
\hline 1.5 & 10.17 & 16.49 & 14.95 & 1130.1 & 18.64 & 9.1 & 0.9984 & $200-1000$ \\
\hline 1.5 & 8.43 & & & & 31.64 & 9.2 & 0.9874 & $200-1000$ \\
\hline 1.5 & 7.03 & & & & 50.88 & 10.1 & 0.9894 & $200-1000$ \\
\hline 1.5 & 5.12 & 17.36 & 12.4 & 1139.6 & 40.29 & 9.3 & 0.9944 & $200-1000$ \\
\hline 2.3 & 11.24 & 20.15 & 19.12 & 1171.6 & 59.46 & 9.4 & 0.9946 & $200-1000$ \\
\hline 2.3 & 8.61 & & & & 85.43 & 14.3 & 0.9811 & $100-1000$ \\
\hline 2.3 & 6.75 & & & & 88.58 & 10.1 & 0.9586 & $200-1000$ \\
\hline 2.3 & 4.77 & 20.84 & 16.44 & 1181.4 & 36.21 & 11.6 & 0.9958 & $200-1000$ \\
\hline 2.5 & 11.14 & 15.66 & 14.74 & 1109.4 & 13.16 & 7.2 & 0.9972 & $200-1000$ \\
\hline 2.5 & 8.75 & & & & 18.95 & 8.1 & 0.9992 & $100-1000$ \\
\hline 2.5 & 6.68 & & & & 19.18 & 9.1 & 0.9966 & $100-1000$ \\
\hline 2.5 & 4.72 & 16.59 & 12.85 & 1131.5 & 10.9 & 6.9 & 0.9964 & $200-1000$ \\
\hline
\end{tabular}

The impact of shifting the $\mathrm{pH}$ was most noticeable with respect to the yield stress of the slurry. As the $\mathrm{pH}$ declined from about 11 to near 7, the yield stress increased in all test cases. The second addition also increased the yield stress. The final acid additions then began to reduce the yield stress. A plot of yield stress as a function of $\mathrm{pH}$ based upon the data in Table 15 is shown in Figure 14. The process of $\mathrm{pH}$ adjustment would be a movement from the right side of the plot to the left side of the plot. A maximum in yield stress occurs near $\mathrm{pH} 7$ based upon all four curves. The existence of the maximum is consistent with prior studies on the effect of $\mathrm{pH}$ on

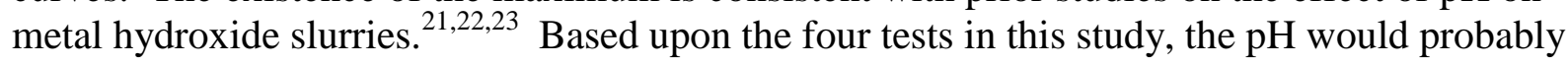
have to be changed to a value less than 5 to achieve any significant reduction in yield stress.

An analysis of the data for consistency does not show any definite trends in the data. Figure 15 does not show any reproducible pattern to the measured values of consistency as a function of $\mathrm{pH}$.

\footnotetext{
${ }^{21}$ Y.K. Leong, P.J.Scales, T. W. Healy, D. V. Bolger, "Interparticle forces arising from adsorbed polyelectrolytes in colloidal suspensions". Colloids and Surfaces A: Physicochemical and Engineering Aspects Vol. 95 p 43-52 (1995).

22 M. Subanna, P. Malghan, and S. G. Malghan, "Shear yield stress of flocculated alumina-zirconia mixed suspensions: effect of solid loading, composition and particle size distribution”. Chemical Engineering Science, Vol. 53, p 3073-3079 (1998).

23 J. P. LaFemina (Task Leader), Tank Waste Treatment Science Task Quarterly Report for January to March 1995, PNL-10763/UC-721, April 1, 1995.
} 
WSRC-TR-2001-00203, Rev. 0

SRT-RPP-2001-00051, Rev. 0

TRPT-24590-01-00001

Figure 14 Yield Stress as a Function of pH at 298 K

Yield Stress as a Function of $\mathrm{pH}$

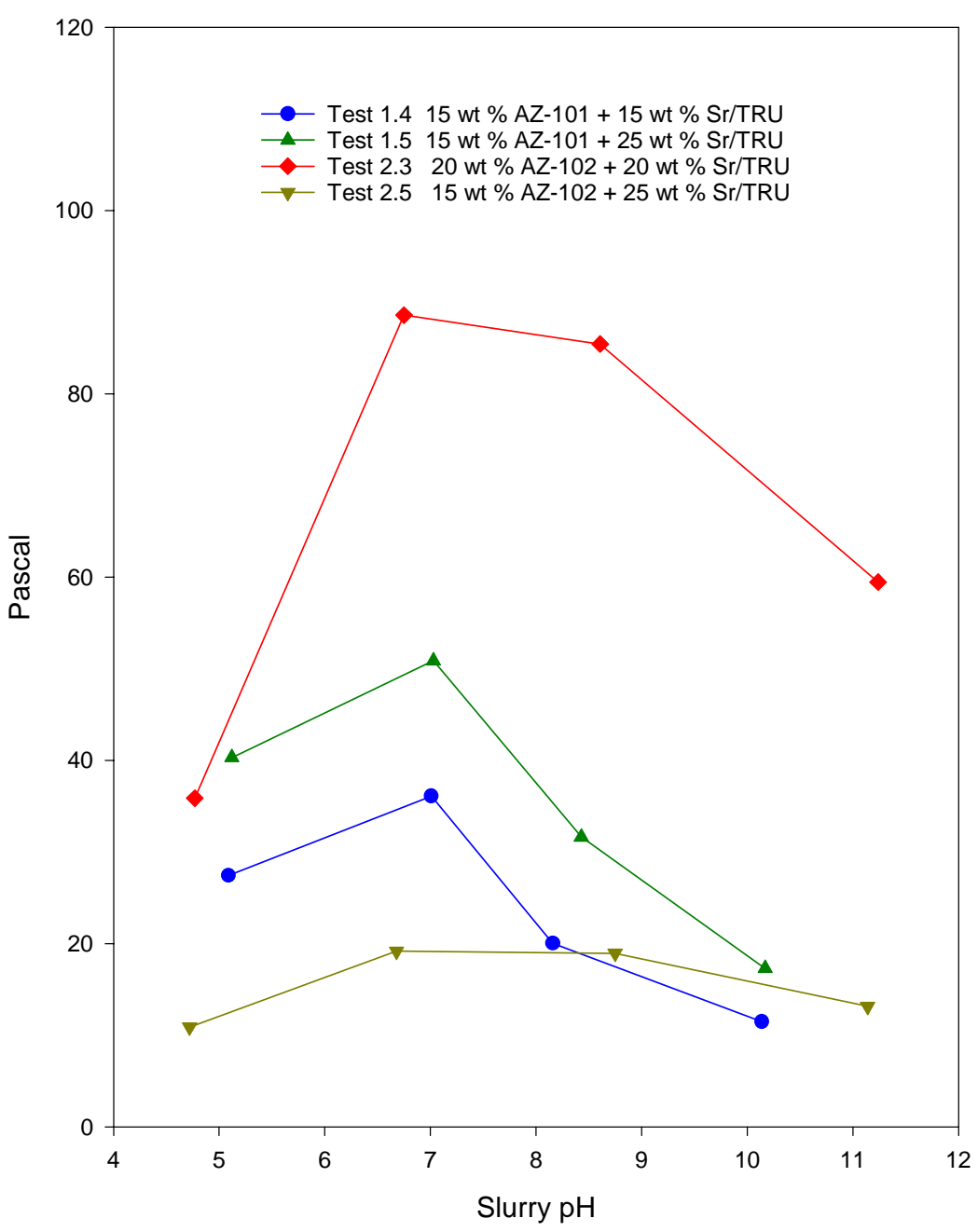


WSRC-TR-2001-00203, Rev. 0

SRT-RPP-2001-00051, Rev. 0 TRPT-24590-01-00001

Figure 15 Consistency as a Function of pH at $298 \mathrm{~K}$

Consistency from a Bingham Model Fit as a Function of $\mathrm{pH}$

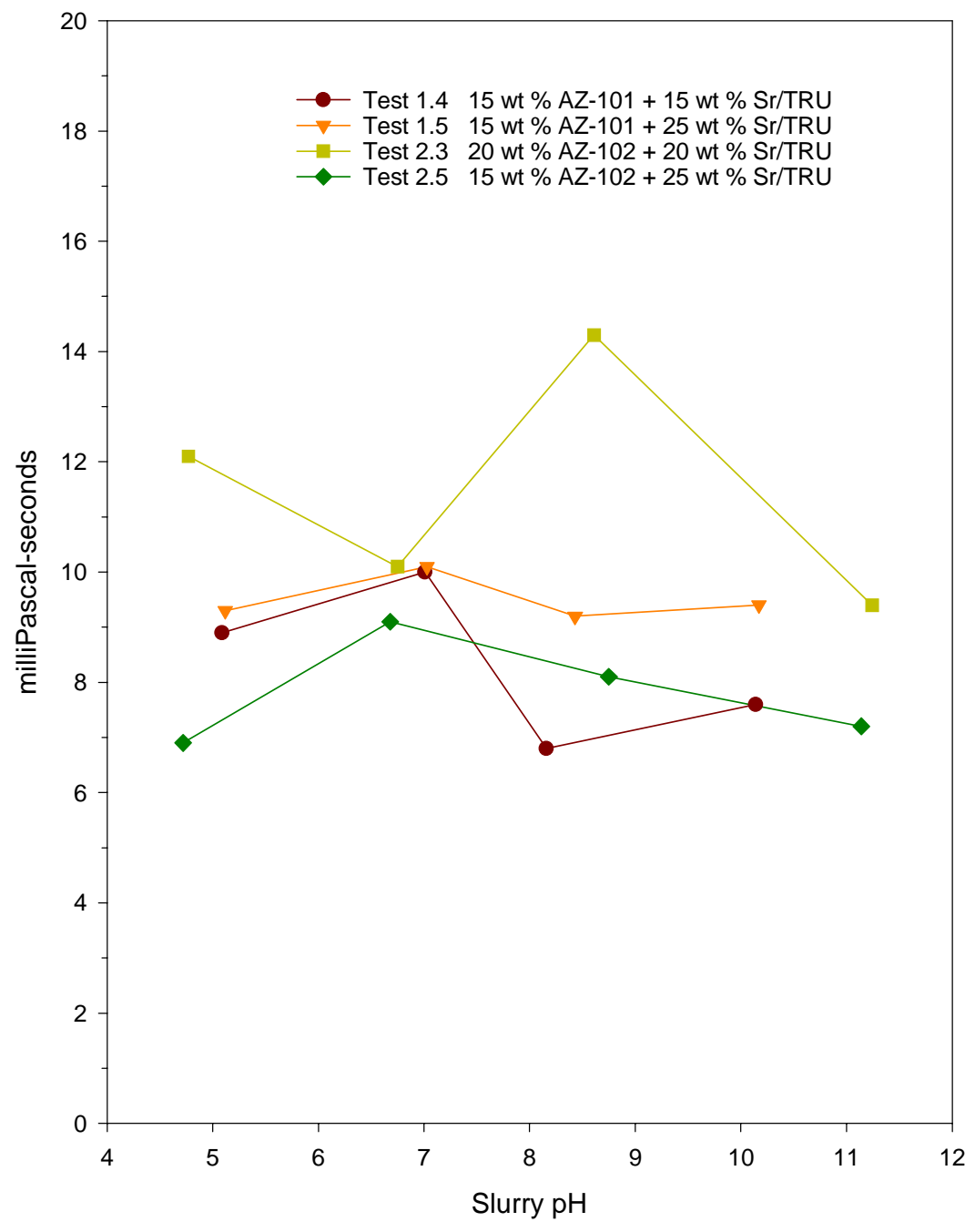

Samples of the supernate from the pH 5 adjusted tests were analyzed for soluble species concentrations to determine the changes in the solids due to $\mathrm{pH}$. Table 16 lists the composition for the supernate at the starting $\mathrm{pH}$ and at the final $\mathrm{pH}$ for all four tests. 
Table 16 Effect of pH Change on Soluble Blend Components

\begin{tabular}{|c|c|c|c|c|c|c|c|c|}
\hline & Test 1.4 & Test 1.4 & Test 1.5 & Test 1.5 & Test 2.3 & Test 2.3 & Test 2.5 & Test 2.5 \\
\hline & $\mathrm{pH} 10.14$ & pH 5.09 & pH 10.17 & $\mathrm{pH} 5.12$ & pH 11.24 & $\mathrm{pH} 4.77$ & $\mathrm{pH} 11.14$ & $\mathrm{pH} 4.72$ \\
\hline Component & $\mathrm{mg} / \mathrm{L}$ & $\mathrm{mg} / \mathrm{L}$ & $\mathrm{mg} / \mathrm{L}$ & $\mathrm{mg} / \mathrm{L}$ & $\mathrm{mg} / \mathrm{L}$ & $\mathrm{mg} / \mathrm{L}$ & $\mathrm{mg} / \mathrm{L}$ & $\mathrm{mg} / \mathrm{L}$ \\
\hline $\mathrm{B}$ & 41 & 41 & 40 & 42 & 32 & 13 & 30 & 16 \\
\hline $\mathrm{Ba}$ & 0.05 & 54 & 0.04 & 52 & $<0.06$ & 53 & 0.02 & 39 \\
\hline $\mathrm{Ca}$ & 2.7 & 696 & 2.8 & 715 & 3 & 454 & 3.1 & 343 \\
\hline $\mathrm{Cd}$ & 4.1 & 871 & 2.2 & 736 & 2.5 & 2950 & 1.8 & 2350 \\
\hline $\mathrm{Co}$ & $<0.04$ & 70 & $<0.04$ & 55 & $<0.2$ & 2.3 & $<0.04$ & 2.7 \\
\hline $\mathrm{Cr}$ & 6.2 & $<0.5$ & 5.8 & $<0.5$ & 22 & $<0.5$ & 17 & $<0.5$ \\
\hline $\mathrm{Fe}$ & $<0.04$ & $<0.4$ & $<0.04$ & $<0.4$ & $<0.2$ & $<0.4$ & $<0.04$ & $<0.4$ \\
\hline $\mathrm{Mg}$ & 0.6 & 61 & 0.6 & 63 & 0.9 & 255 & 0.6 & 192 \\
\hline $\mathrm{Mn}$ & 0.2 & 935 & 0.1 & 830 & $<0.05$ & 459 & $<0.01$ & 471 \\
\hline $\mathrm{Na}$ & 5680 & 8840 & 5320 & 8890 & 4410 & 6110 & 3750 & 5060 \\
\hline $\mathrm{K}$ & 409 & 624 & 409 & 655 & 38 & 58 & 28 & 30 \\
\hline $\mathrm{Ni}$ & 2.6 & 453 & 1.5 & 365 & 2.1 & 1120 & 1.3 & 910 \\
\hline $\mathrm{Sr}$ & 0.14 & 5690 & 0.15 & 6200 & 0.29 & 5670 & 0.16 & 4460 \\
\hline Nitrate & 4380 & 39110 & 4750 & 39100 & 3020 & 35500 & 2190 & 26950 \\
\hline Nitrite & 3780 & 1860 & 3980 & 1990 & 1085 & 260 & 1010 & 272 \\
\hline Chloride & 93 & 57 & 98 & 59 & 341 & 205 & 313 & 208 \\
\hline Fluoride & 71 & $<20$ & 75 & $<20$ & 40 & $<20$ & 42 & $<20$ \\
\hline Sulfate & 749 & 37 & 764 & 44 & 453 & 17 & 369 & 17 \\
\hline
\end{tabular}


WSRC-TR-2001-00203, Rev. 0

The replacement of carbonate with nitrate can be seen in the increase in solubility of the following metals, which form sparingly soluble carbonates: $\mathrm{Ba}, \mathrm{Ca}, \mathrm{Mg}, \mathrm{Mn}$, and $\mathrm{Sr}$. Since most of these also form sparingly soluble fluorides and sulfates, the drop in fluoride and in sulfate is consistent with an increase in the metal ion in solution. Barium also forms an insoluble chromate, which would explain the drop in chromium assuming that it is present in the supernate as chromate. The increase in soluble manganese indicates that $\mathrm{Mn}$ (II) is present in the blend since $\mathrm{Mn}$ (IV) forms an insoluble oxide $\left(\mathrm{MnO}_{2}\right)$. Since both the AZ-102 and AZ-101 sludges were produced with $\mathrm{MnO}_{2}$, the soluble $\mathrm{Mn}(\mathrm{II})$ must come from the Sr/TRU precipitate. The decrease in soluble nitrite is probably due to acid decomposition of the nitrite during $\mathrm{pH}$ adjustment. The increase in solubility of $\mathrm{Cd}$, $\mathrm{Co}$ and $\mathrm{Ni}$ is consistent with the solubility curves of their hydroxide species. The lack of dissolution of iron is also consistent with the $\mathrm{pH}$ achieved and the solubility curve for Fe(III) hydroxides.

\section{AZ-101 + Blended Compositions + Glass Formers}

The $\mathrm{pH}$, solids analyses, and rheological results are shown in Table 17 for the various AZ-101 test mixtures combined with glass formers. The particle size data for the AZ-101 test mixtures with glass formers is shown in Appendix A. The blended combinations seem to have little effect on $\mathrm{pH}$, even after the glass formers have been added. Insoluble solids analysis could not be performed for test mixtures $1.3,1.4$, and 1.5 , since the available amount of slurry made did not lead to enough supernate to be separated from the structure. The flow curves are shown in FIGURE A - 12 in the appendix. The flow curves in this figure are such that 3 of the 5 curves (tests 1.4, 1.5, ADD-2) had return curves that were above the up curves. This could mean that these slurries are rheopectic, and would have to be verified by measuring the flow curve using other geometry's. These flow curves could also be due to edge effects, where drying would be the issue. Comparing the baseline data in Table 7 to Table 17, the yield stress and consistency have both increased drastically due to the addition of glass formers. These large differences will impact both mixing and transport issues, given that this process will be performed in one vessel.

Table 17 Physical and Rheological Data for AZ-101 Blended Compositions + Glass Formers

\begin{tabular}{|c|c|c|c|c|c|c|c|c|}
\hline \multirow{2}{*}{$\begin{array}{c}\text { Test } \\
\text { Mixture }\end{array}$} & \multirow[t]{2}{*}{$\mathrm{pH}$} & \multicolumn{2}{|c|}{$\begin{array}{l}\text { wt. \% Solids Analysis } \\
\text { Oven Method }\end{array}$} & \multirow{2}{*}{$\begin{array}{l}\text { Density } \\
\left(\mathrm{kg} / \mathrm{m}^{3}\right)\end{array}$} & \multirow{2}{*}{$\begin{array}{c}\text { Yield } \\
\text { Stress }(\mathrm{Pa})\end{array}$} & \multirow{2}{*}{$\begin{array}{l}\text { Consistency } \\
(\mathrm{mPa}-\mathrm{sec})\end{array}$} & \multirow[t]{2}{*}{$\mathrm{R}^{2}$} & \multirow{2}{*}{$\begin{array}{l}\text { Fitted Shear rate } \\
\text { range }\left(\mathrm{sec}^{-1}\right)\end{array}$} \\
\hline & & Total & Insoluble & & & & & \\
\hline 1.3 & 10.2 & 39.05 & $*$ & 1387 & 340.3 & 123.9 & 0.9966 & $\mathrm{~d}: 100-1000$ \\
\hline 1.4 & 10.3 & 32.47 & $*$ & 1321 & 48.52 & 37.3 & 0.9990 & $\mathrm{u}: 100-1000$ \\
\hline 1.5 & 10.3 & 33.66 & $*$ & 1308 & 76.83 & 56.6 & 0.9990 & $\mathrm{u}: 100-1000$ \\
\hline ADD-1 & 10.2 & 24.71 & 20.37 & 1218 & 2.55 & 6.8 & 0.9892 & $\mathrm{~d}: 200-1000$ \\
\hline ADD-2 & 10.2 & 30.02 & 24.08 & 1248 & 11.54 & 12.4 & 0.9990 & $\mathrm{u}: 100-1000$ \\
\hline
\end{tabular}

* Centrifuging could not separate enough supernate for measurement

Test mixture 1.4 was selected as the blend that would be mixed for 30 days to see if there were any dynamic effects on rheology. Samples of this blend were taken at specified time intervals to look at the $\mathrm{pH}$, total solids, and rheology. The results are shown in Table 18 The flow curves are shown in FIGURE A - 13. All the flow curves, except for the $2 \mathrm{hr}$ measurement, were such that the down curve was slightly below the up, indicating slight thixotropic characteristics. The $2 \mathrm{hr}$ flow curve shows rheopectic behavior, but this would have to be confirmed. The 30-day test only lasted 23 days, before the test was stopped, due to the limited change in yield stress between the 19 and 23-day measurements. In Table 18, both the yield stress and 
consistency decrease over time, which indicates this slurry is not stable with respect to rheological properties. The $\mathrm{pH}$ and weight $\%$ TS also changed, but not drastically. The proposed reason for this behavior is that the glass formers used in this test, specifically $\mathrm{LiOH}$ and $\mathrm{NaOH}$, reacted with the aluminum to form a soluble salt over time. The result would be a decrease in insoluble solids and an increase in soluble solids. Considering the large reduction in yield stress, the use of hydroxide forms of the alkali metals could help in improving the flow characteristics of the HLW melter feed.

Table 18 Total Solids and Rheological Data for AZ-101 Test 1.4 - 30 Day Test

\begin{tabular}{|c|c|c|c|c|c|c||}
\hline \hline Time & $\mathrm{pH}$ & $\begin{array}{c}\text { wt. \% Total Solids } \\
\text { Oven Method }\end{array}$ & $\begin{array}{c}\text { Yield } \\
\text { Stress (Pa) }\end{array}$ & $\begin{array}{c}\text { Consistency } \\
(\mathrm{mPa}-\mathrm{sec})\end{array}$ & $\mathrm{R}^{2}$ & $\begin{array}{c}\text { Fitted Shear rate } \\
\text { range }\left(\mathrm{sec}^{-1}\right)\end{array}$ \\
\hline 2 hours & 9.97 & 32.25 & 39.95 & 31.94 & 0.9998 & $100-1000$ \\
\hline 1 day & 9.99 & 32.11 & 32.81 & 19.16 & 0.9992 & $100-1000$ \\
\hline 3 days & 10.02 & 32.05 & 29.03 & 15.35 & 0.9997 & $100-1000$ \\
\hline 19 days & 9.82 & 31.94 & 13.23 & 11.42 & 0.9991 & $100-1000$ \\
\hline 23 days & 9.73 & 31.80 & 11.37 & 9.90 & 0.9871 & $100-1000$ \\
\hline
\end{tabular}

\section{AZ-102 + Blended Compositions + Glass Formers}

The $\mathrm{pH}$, solids analyses, and rheological results are shown in Table 19 for the various AZ-102 test mixtures. The particle size data for the AZ-102 test mixtures with glass formers is shown in Appendix A. The addition of glass formers causes the $\mathrm{pH}$ of the blended mixture to decrease. The flow curves are shown in FIGURE A 14 in Appendix A. These flow curves show very few thixotropic characteristics, unlike the AZ-101 blends + glass formers. Comparing the base line data in Table 7 to Table 19 the yield stress and consistency have both increased slightly due to the addition of glass formers. The largest change is in the consistency. These changes will impact mixing and pumping issues, but the degree of impact will need to be quantified based on the process equipment being used.

Table 19 Physical and Rheological Data for AZ-102 Blended Compositions + Glass Formers

\begin{tabular}{|c|c|c|c|c|c|c|c|c|}
\hline \multirow{2}{*}{$\begin{array}{c}\text { Test } \\
\text { Mixture }\end{array}$} & \multirow{2}{*}{$\mathrm{pH}$} & \multicolumn{2}{|c|}{$\begin{array}{l}\text { wt. \% Solids Analysis } \\
\text { Oven Method }\end{array}$} & \multirow{2}{*}{$\begin{array}{l}\text { Density } \\
\left(\mathrm{kg} / \mathrm{m}^{3}\right)\end{array}$} & \multirow{2}{*}{$\begin{array}{c}\text { Yield } \\
\text { Stress (Pa) }\end{array}$} & \multirow{2}{*}{$\begin{array}{c}\text { Consistency } \\
(\mathrm{mPa}-\mathrm{sec})\end{array}$} & \multirow[t]{2}{*}{$\mathrm{R}^{2}$} & \multirow{2}{*}{$\begin{array}{l}\text { Fitted Shear rate } \\
\text { range }\left(\mathrm{sec}^{-1}\right)\end{array}$} \\
\hline & & Total & Insoluble & & & & & \\
\hline 2.3 & 10.5 & 39.82 & $5.68 * *$ & 1418 & $*$ & $*$ & & \\
\hline 2.4 & 9.69 & 32.96 & $7.34 * *$ & 1305 & 14.97 & 15.12 & 0.9952 & $200-1000$ \\
\hline 2.5 & 10.03 & 33.65 & $7.84 * *$ & 1341 & 15.97 & 15.76 & 0.9946 & $200-1000$ \\
\hline 2.9 & 9.68 & 41.39 & $*$ & 1438 & $*$ & $*$ & & \\
\hline ADD-3 & 10.35 & 24.93 & $*$ & 1227 & 3.28 & 6.46 & 0.9982 & $200-1000$ \\
\hline ADD-4 & 10.24 & 28.77 & $*$ & 1268 & 7.19 & 9.40 & 0.9964 & $200-1000$ \\
\hline
\end{tabular}




\section{Conclusions and Recommendations}

The HLW mixing study produced two washed simulated sludges (representing tanks 241-AZ-101 and 241AZ-102 sludge), a Sr/TRU washed precipitate produced from tank 241-AZ-107 simulant, and a concentrated blended eluate simulant based upon eluates from processing 241-AZ-102 supernate. The physical properties and rheological properties of these individual products and their planned blends with and without glass formers were measured. Based upon these results the following conclusions were found.

- Shearing reduces the particle size and modifies the particle size distribution for the simulated sludges and the Sr/TRU precipitate, which could impact filtration.

- Shearing the $\mathrm{Sr} / \mathrm{TRU}$ precipitate reduced the yield stress of the precipitate.

- The rheological properties of the AZ-101 and AZ-102 simulated sludges and the Sr/TRU precipitate are distinctly nonnewtonian and can be represented by a Bingham flow model.

- The blended eluate simulant is a Newtonian fluid.

- The yield stress as determined by the vane method appears to agree well with the maximum observed in the initial portion of the up flow. This could be an indication that slip is occurring in the flow curve measurement.

- The yield stress (Bingham model) is a strong function of the insoluble solids loading for the AZ-101, AZ-102 simulated sludges and for the simulated AN-107 Sr/TRU precipitate.

- The consistency of the simulated sludges is not significantly impacted by the change in insoluble solids until very high solids loading are reached.

- A comparison of the simulated AZ-102 sludge to the actual AZ-102 waste indicates that the simulant's rheology behaves similarly to the real waste.

- Physical property relationships were determined for the slurries including weight percent total solids, weight percent insoluble solids, and density.

- Yield stress relationships were determined for both sludges and precipitate as functions of either total solids or insoluble solids.

- The viscosity and heat capacity of the blended eluate simulant were determined.

- The yield stress of the blended wastes was strongly effected by $\mathrm{pH}$ with a maximum probably near $\mathrm{pH} 7$.

- The variation in consistency of the simulated sludges was poorly correlated to the change in $\mathrm{pH}$.

- Addition of acid to improve rheology (reduce yield stress) would require reducing the $\mathrm{pH}$ to below $\mathrm{pH} 5$ to achieve significant improvement.

- The addition of an equal-solids-loaded Sr/TRU precipitate to an Envelope D waste of similar solids loading will act to slightly reduce the yield stress by diluting the sludge solids.

- The rheological behavior of the blended compositions of LAW waste streams ( $\mathrm{Sr} / \mathrm{TRU}$ precipitate \& Eluate) with the base HLW sludge did not greatly impact the rheological behavior of the base HLW sludge.

- The addition of small amounts of the blended eluate will not impact the $\mathrm{pH}$ of the simulated sludge.

- Time dependent effects on rheology were observed upon addition of glass formers containing LiOH and $\mathrm{NaOH}$. Rheology of sludge became thinner over time.

- Drying of the slurries at elevated temperatures interfered with obtaining the rheology measurements using the cone and plate on the Haake RS150.

- Since there is no present design basis of the HLW vitrification plant, specifically mixing and transport, the impact of the physical characteristics of the slurries quantified in this study on the HLW vitrification process are unknown. 
WSRC-TR-2001-00203, Rev. 0

- Since there is no present design basis of the effected pre-treatment plant, specifically mixing and transport, the impact of the physical characteristics of the Sr/TRU precipitate slurries and Cs/Tc eluate quantified in this study are unknown.

Based upon these conclusions and the other observations that occurred during the study, the following recommendations should be considered when planning additional HLW mixing studies.

- If slippage is evident in the flow curve measurement, then yield stress measurement using the vane rotor and flow curve using a different concentric rotor or parallel plate gaps is recommended to characterize the yield stress and to correct the flow curve. Such tests should include both simulant and actual waste studies.

- Any HLW blending or processing studies must include the expected shearing, since shearing impacts particle size and the flow properties of the waste simulants.

- If acid adjustment of waste $\mathrm{pH}$ is considered, then the adjustment must target a $\mathrm{pH}$ less than 5 to avoid the peak in yield stress observed near $\mathrm{pH} 7$.

- Acid neutralization studies of HLW should include variations of HLW waste streams blends, such as sludge $+\mathrm{Cs}$, sludge $+\mathrm{Tc}$, sludge $+\mathrm{Sr} / \mathrm{TRU}$ precipitate, sludge $+\mathrm{Sr} / \mathrm{TRU}$ precipitate $+\mathrm{Tc}$, etc.

- If acidification of the HLW is added to the WTP process, then additional studies are necessary to determine the limiting $\mathrm{pH}$ based upon the settling properties of the slurry, to determine the heat of neutralization, to determine the generation rate and composition of offgas, and to determine the impact of acidification on melter feed properties and glass formulation.

- The use of caustic glass formers such as $\mathrm{LiOH}$ and $\mathrm{NaOH}$ can benefit the rheology of melter feed by reducing the yield stress of the feed.

- Additional work on modifying the production of sludge simulants through precipitation is recommended. Such studies should aim to decrease the gelatinous nature of the primary metal hydroxide precipitates. 
WSRC-TR-2001-00203, Rev. 0

SRT-RPP-2001-00051, Rev. 0

TRPT-24590-01-00001

\section{APPENDIX A: Rheograms and Particle Size Results}

\section{Table of Appendix A Figures}

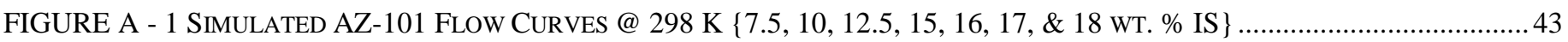
FIGURE A - 2 SIMULATED AZ-101 FLOW CURVE @ 293 K, 20 WT. \% IS ..........................................................................44

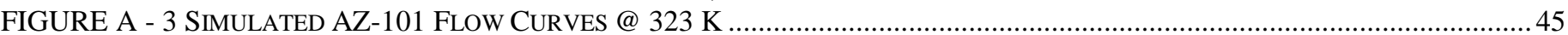

FIGURE A - 4 SIMULATED AZ-101. 15 WT. \%, $2^{\text {ND }}$ BATCH, FLOW CURVE @ 298 K ........................................................46

FIGURE A - 5 SIMULATED AZ-101, 15 WT. \% IS YIELD STRESS USING FL-22 VANE FOR VARIOUS ROTATIONAL SPEEDS @ 298 K

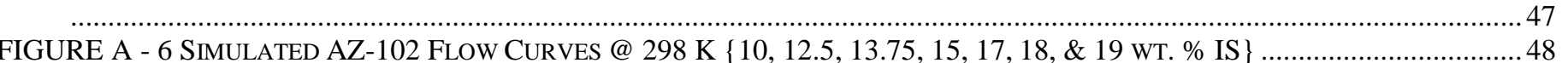

FIGURE A - 7 SIMULATED AZ-102 FLOW CURVES @ 298 K FOR 20 WT. \% IS..................................................................49

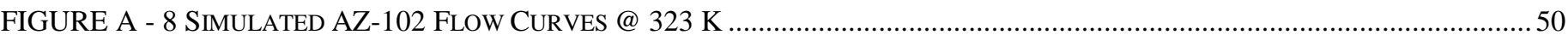

FIGURE A - 9 SIMULATED AN-107, SR/TRU PRECIPITATED/WASHED SLUDGE FLOW CURVES @ 298 K............................... 51

FIGURE A - 10 SIMULATED AN-107, SR/TRU PRECIPITATED/WASHED SLUDGE FlOW CURVES @ 323 K...............................52

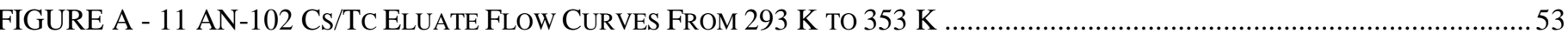

FIGURE A - 12 FLOW CURVES FOR TEST 1.3, 1.4, 1.5, ADD-1, \& ADD-2 WITH GLASS FORMERS @ 298 K.............................54

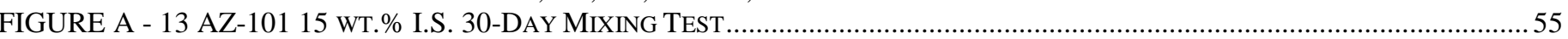

FIGURE A - 14 FLOW CURVES FOR TEST 2.3, 2.4, 3.5, 2.9, ADD-3, \& ADD-4 @ 298 K .....................................................56

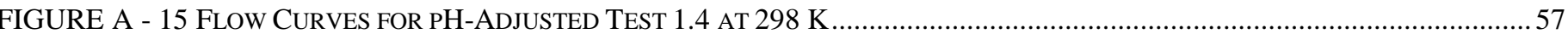

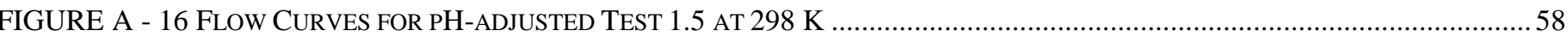

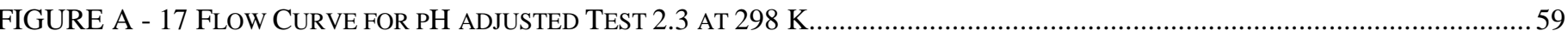

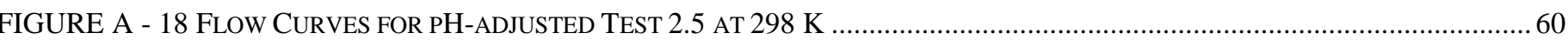

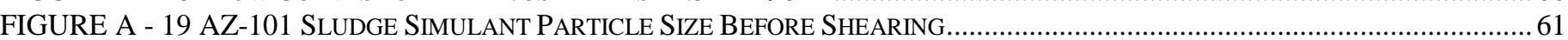

FIGURE A - 20 AZ-101 SLUDGE SIMULANT PARTICLE SIZE AFTER SHEARING ............................................................ 61

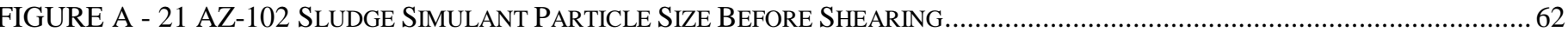

FIGURE A - 22 AZ-102 SLUDGE SIMULANT PARTICLE SIZE AFTER SHEARING ...................................................... 62

FIGURE A - 23 AN-107 SR/TRU PREP/WASHED PARTICLE SIZE BEFORE SHEARING .........................................................63

FIGURE A - 24 AN-107 SR/TRU PREP/WASHED PARTICLE SIZE AFTER SHEARING .........................................................63

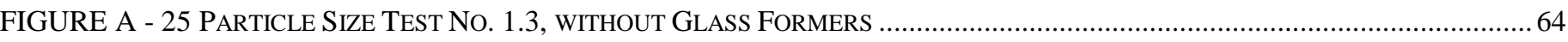

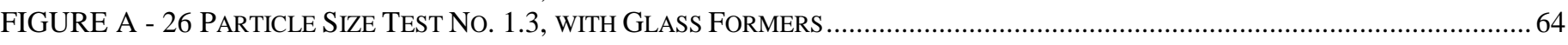

FIGURE A - 27 PARTICLE SIZE TEST NO. 1.4, WITHOUT GLASS FORMERS .....................................................................65

FIGURE A - 28 PARTICLE SIZE TEST NO. 1.4, WITH GLASS FORMERS . .......................................................................65

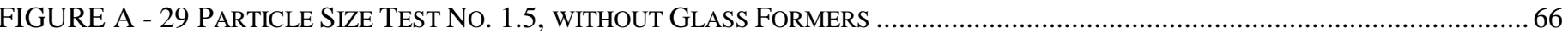

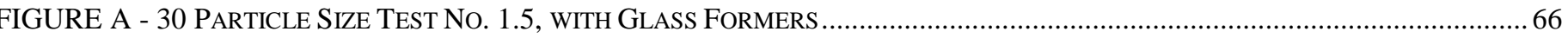

FIGURE A - 31 PARTICLE SIZE TEST NO. ADD-1, WITHOUT GLASS FORMERS ................................................................6 67

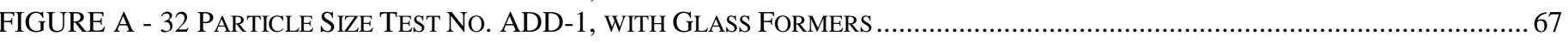

FIGURE A - 33 PARTICLE SIZE TEST NO. ADD-2, WITHOUT GLASS FORMERS ......................................................... 68

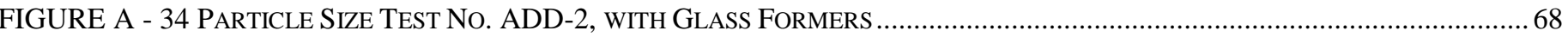

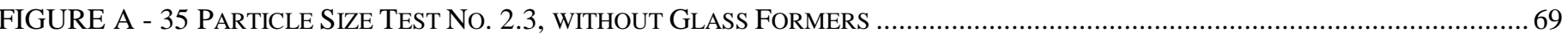

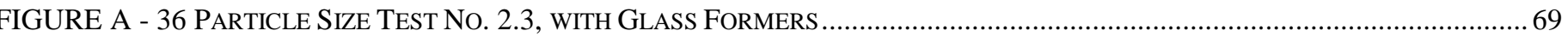

FIGURE A - 37 PARTICLE SIZE TEST NO. 2.4, WITHOUT GLASS FORMERS . ...........................................................

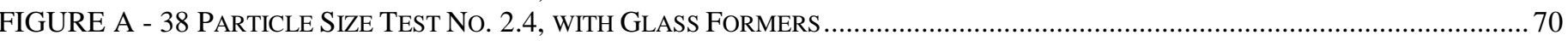

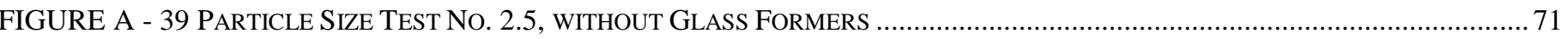

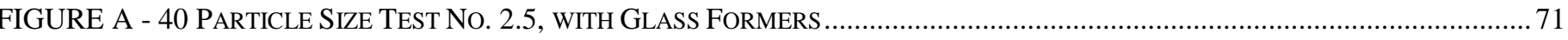

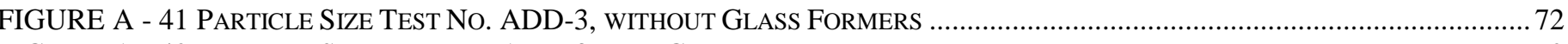

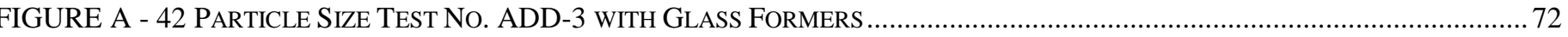

FIGURE A - 43 PARTICLE SIZE TEST NO. ADD-4, WITHOUT GLASS FORMERS ............................................................... 73

EIGURE A - 44 PARTICLE SIZE TEST NO. ADD-4, WITH GLASS FORMERS ................................................................ 
FIGURE A - 1 Simulated AZ-101 Flow Curves@ 298 K \{7.5, 10, 12.5, 15, 16, 17, \& 18 wt. \% IS $\}$

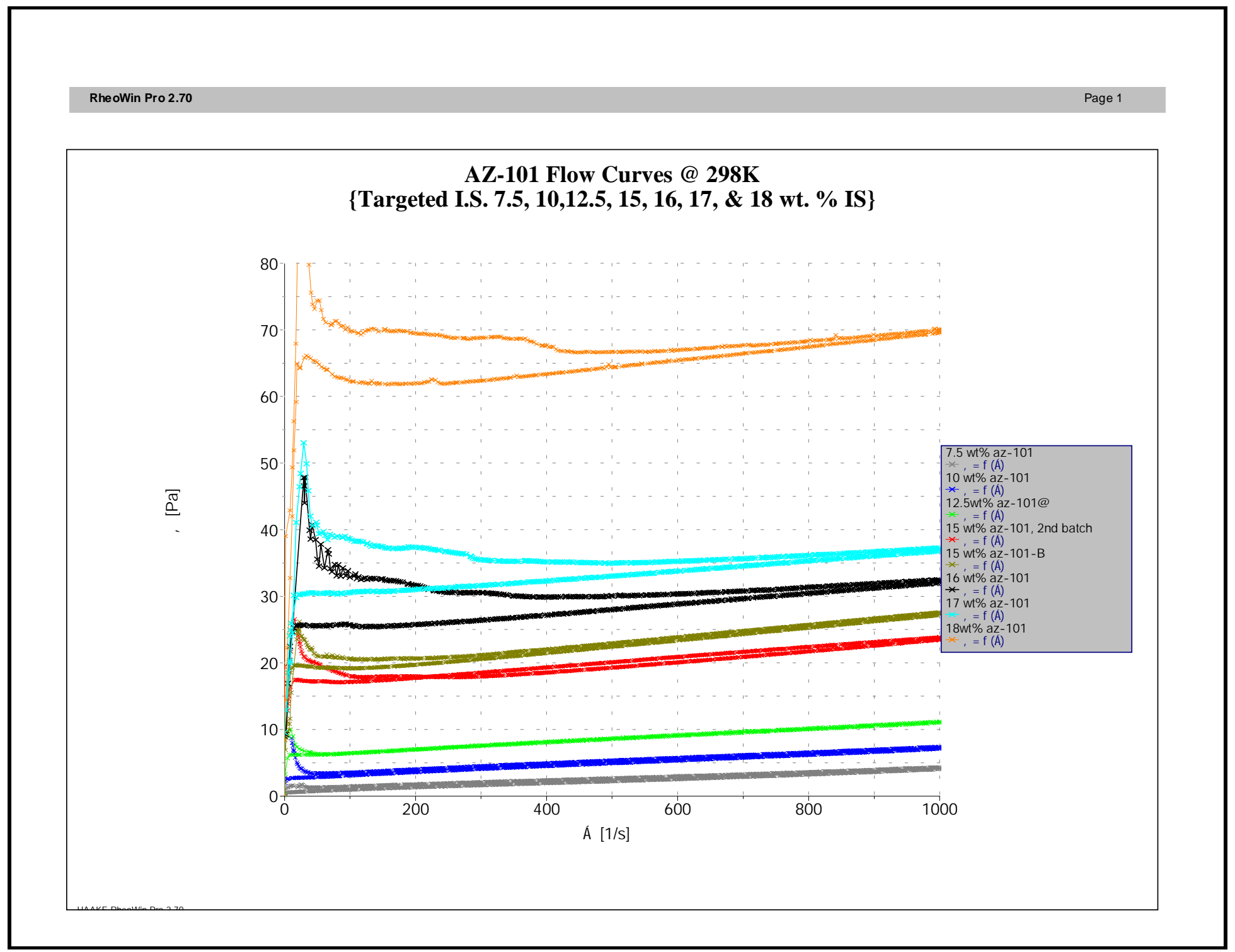

43 of 126 
FIGURE A - 2 Simulated AZ-101 Flow Curve @ 293 K, 20 wt. \% IS

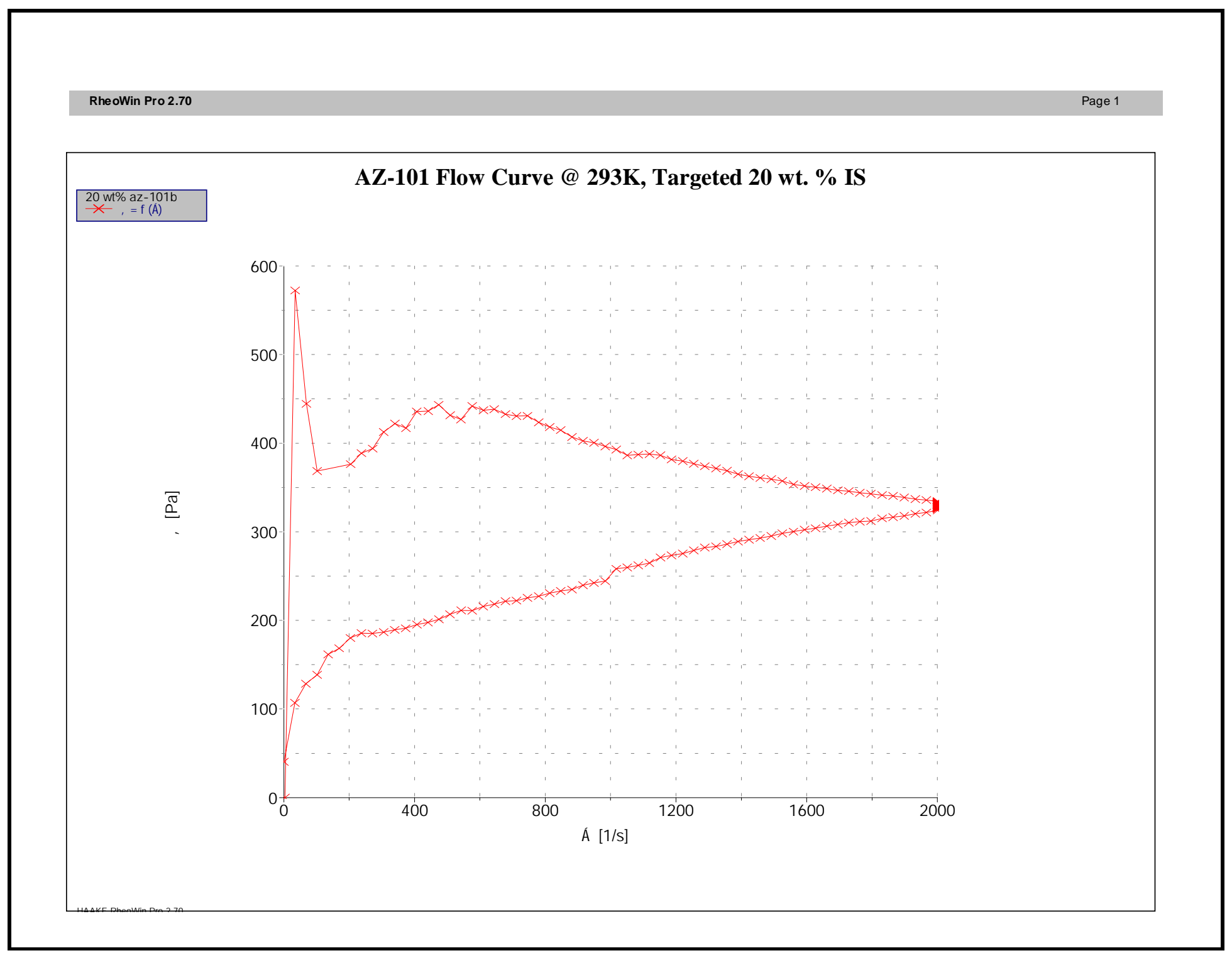

44 of 126 
FIGURE A - 3 Simulated AZ-101 Flow Curves @ 323 K

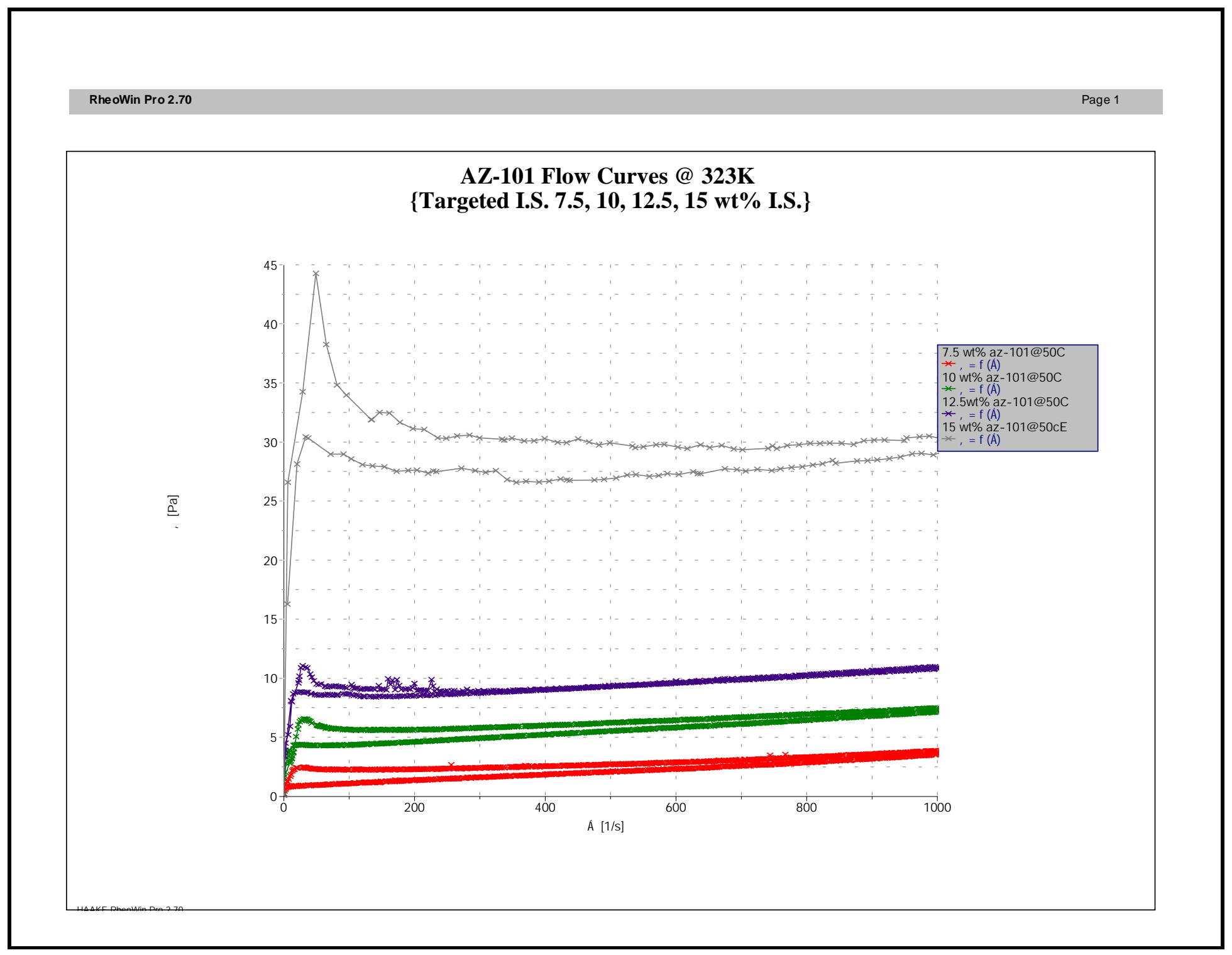

45 of 126 
FIGURE A - 4 Simulated AZ-101. 15 wt. \%, $2^{\text {nd }}$ Batch, Flow Curve @ 298 K

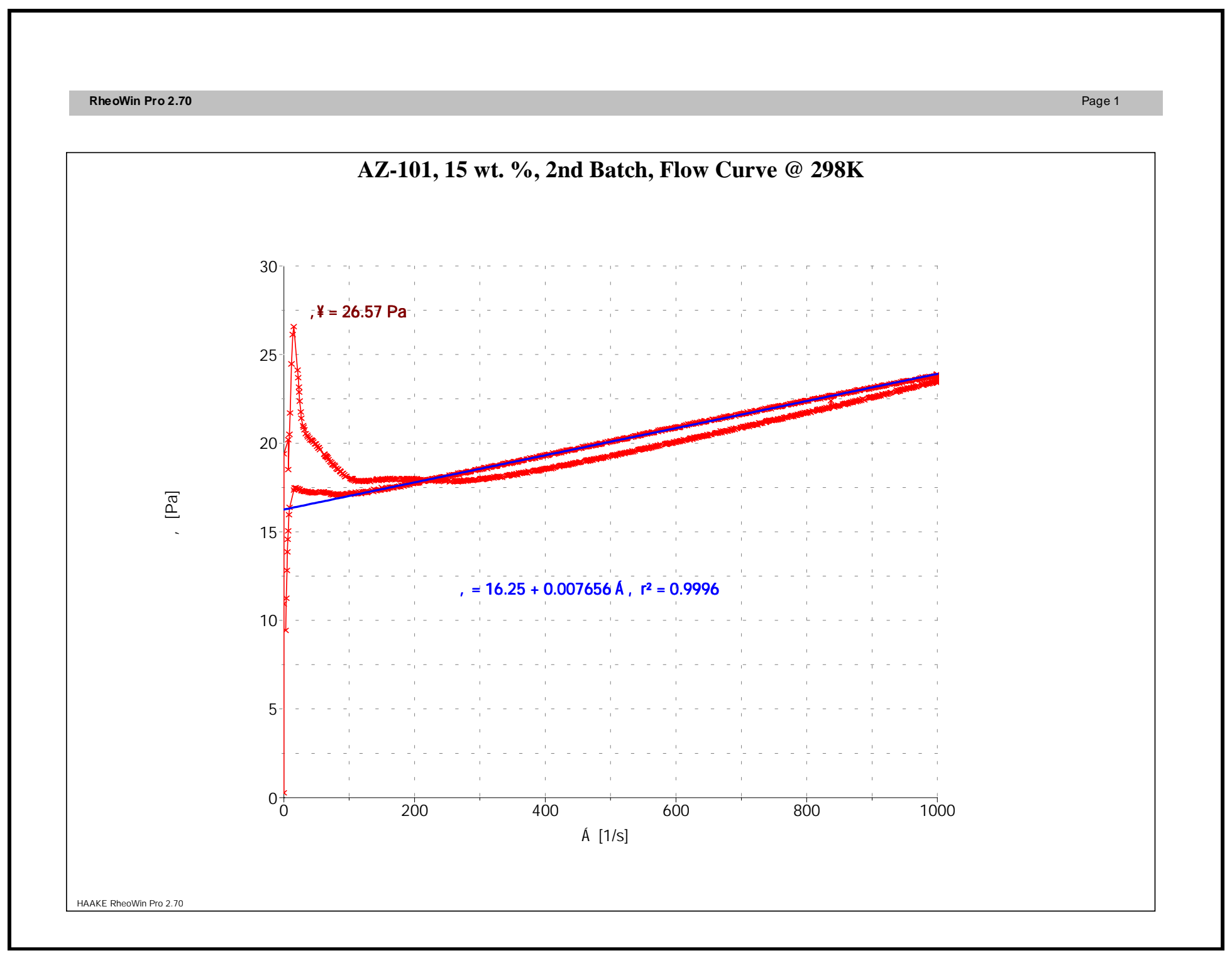

46 of 126 
FIGURE A - 5 Simulated AZ-101, 15 wt. \% IS Yield Stress Using FL-22 Vane for Various Rotational Speeds @ 298 K

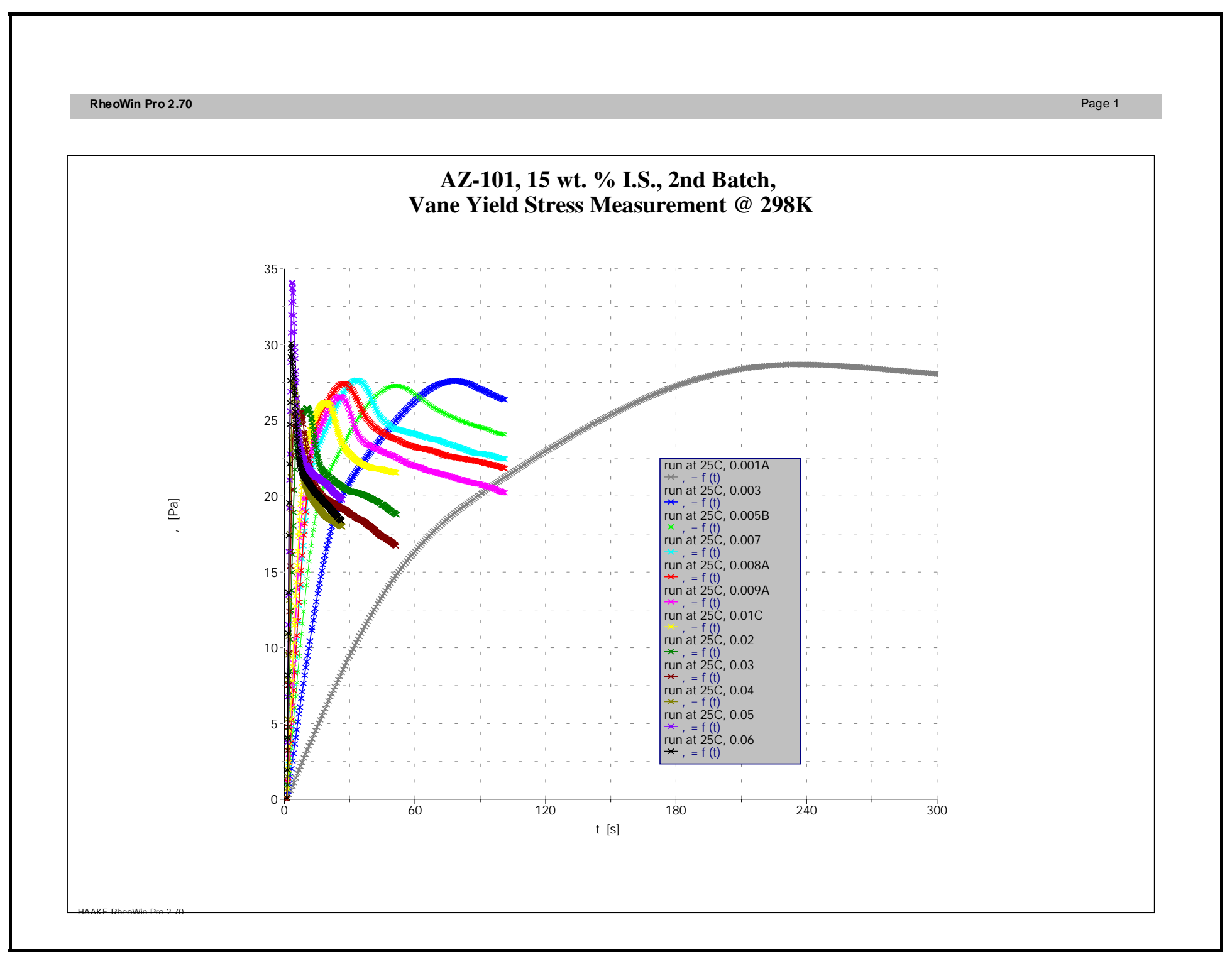

47 of 126 
FIGURE A - 6 Simulated AZ-102 Flow Curves @ 298 K \{10, 12.5, 13.75, 15, 17, 18, \& 19 wt. \% IS $\}$

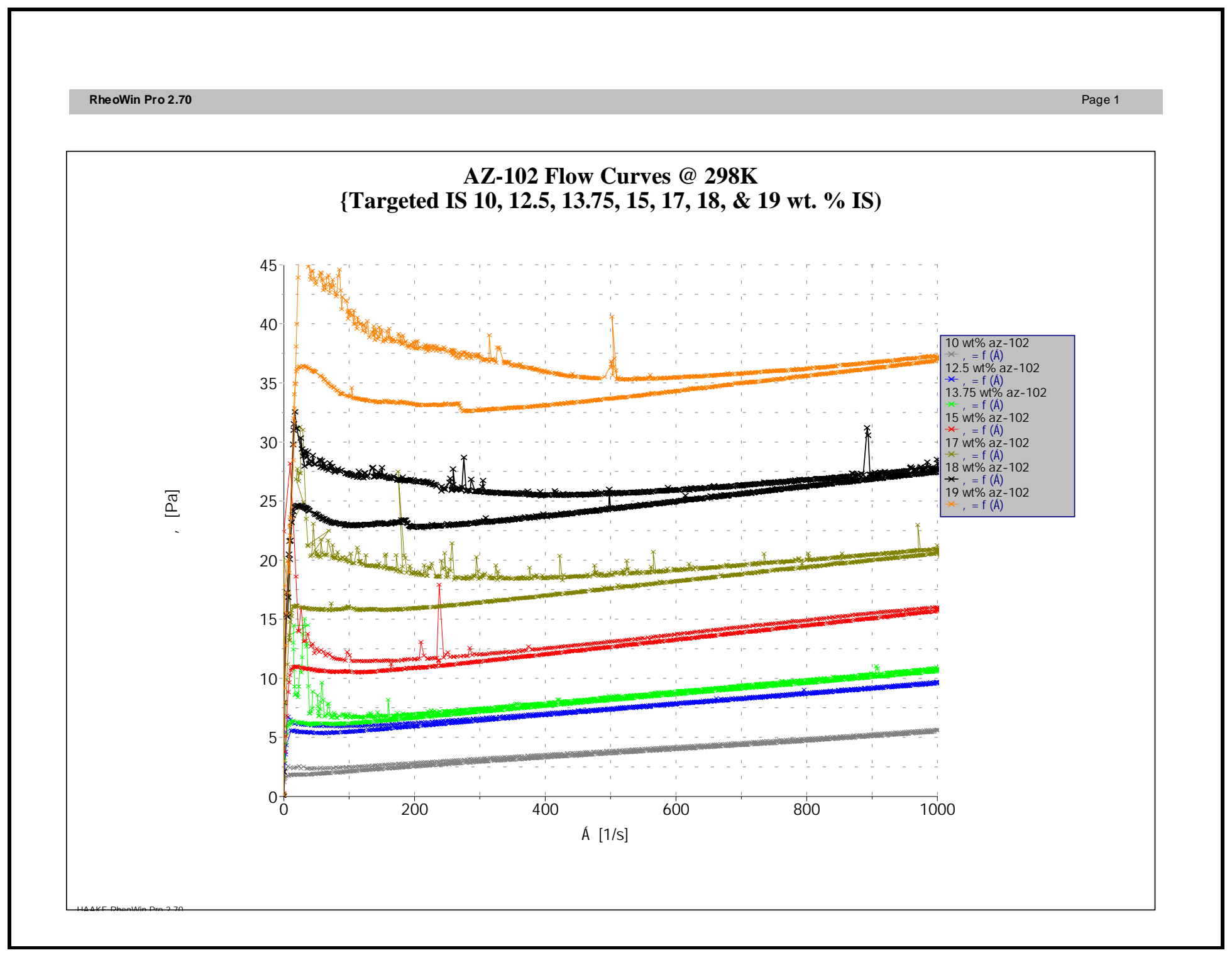

48 of 126 
FIGURE A - 7 Simulated AZ-102 Flow Curves @ 298 K for 20 wt. \% IS

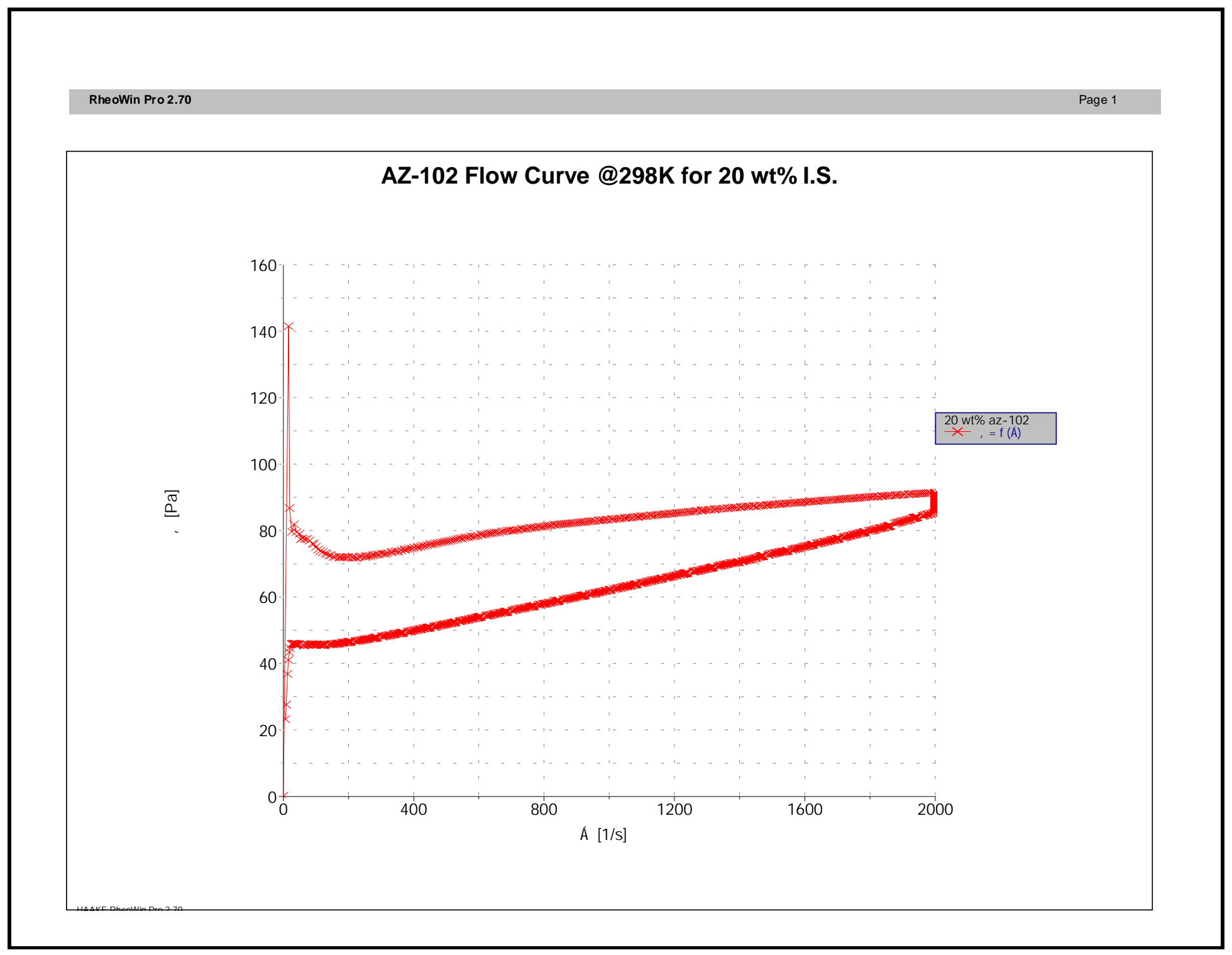

49 of 126 
FIGURE A - 8 Simulated AZ-102 Flow Curves @ 323 K

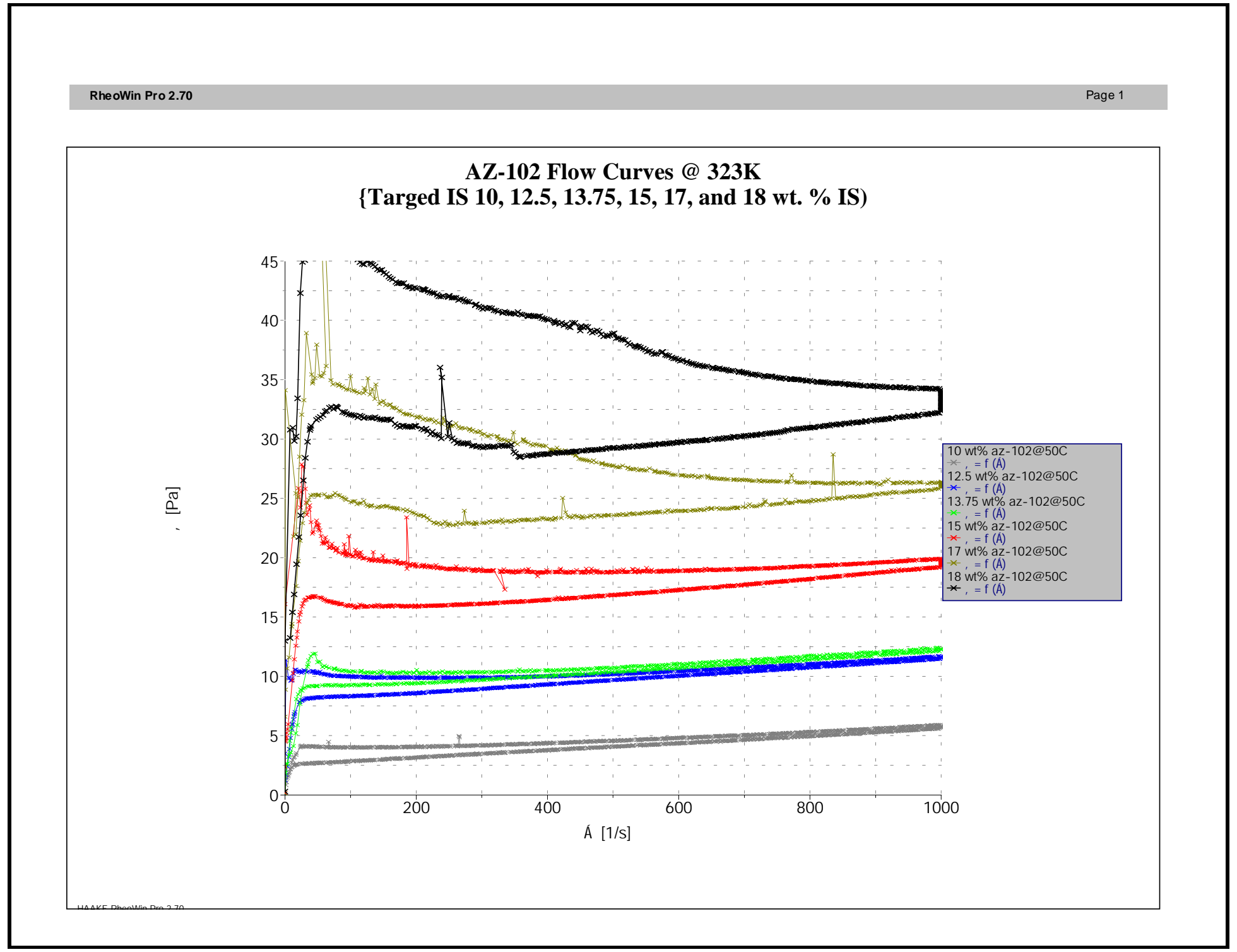


FIGURE A - 9 Simulated AN-107, Sr/TRU Precipitated/Washed Sludge Flow Curves @ 298 K

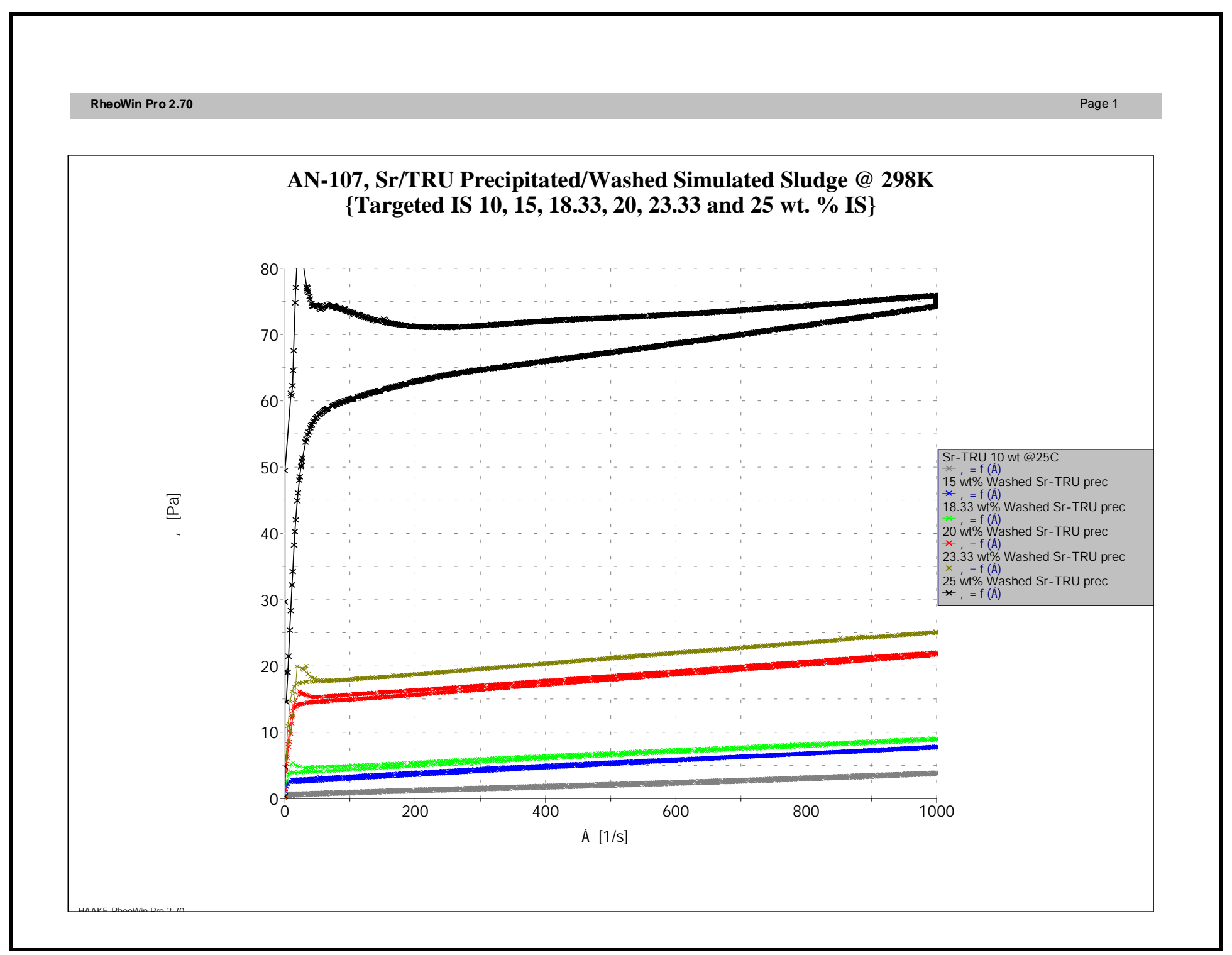

51 of 126 
FIGURE A - 10 Simulated AN-107, Sr/TRU Precipitated/Washed Sludge Flow Curves @ 323 K

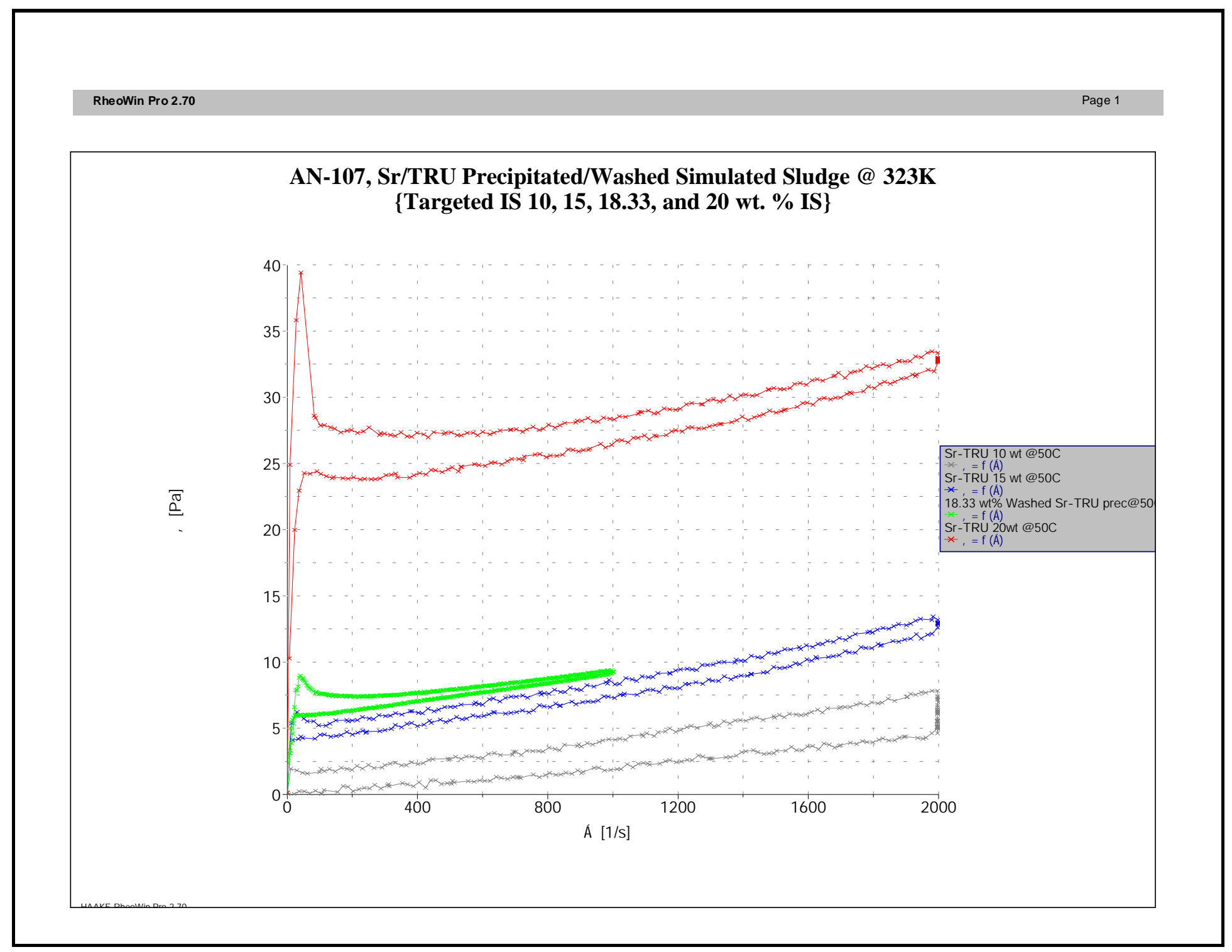


WSRC-TR-2001-00203, Rev. 0

SRT-RPP-2001-00051, Rev. 0

TRPT-24590-01-00001

FIGURE A - 11 AN-102 Cs/Tc Eluate Flow Curves From 293 K to 353 K

RheoWin Pro $2.70 \quad$ Page 1

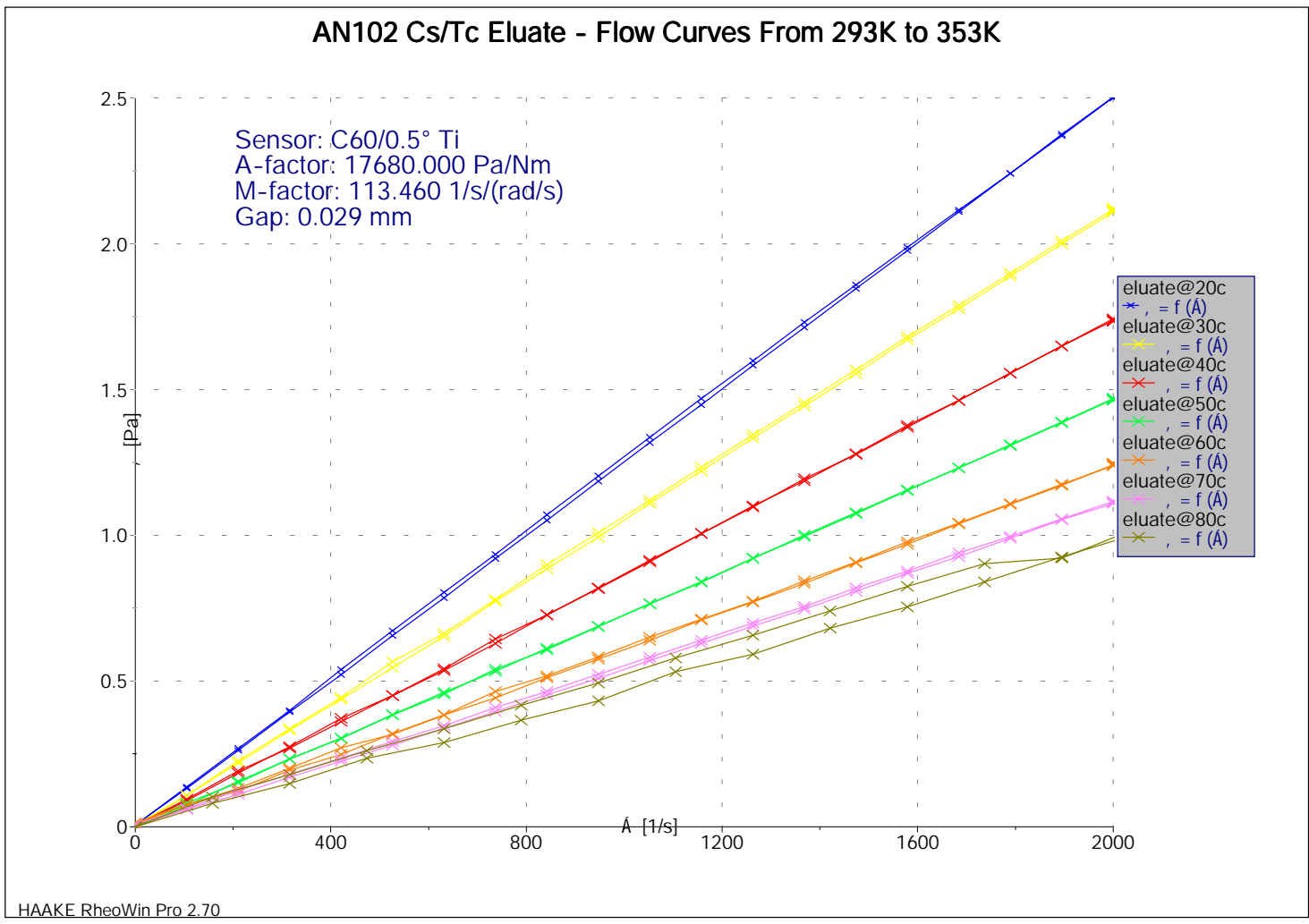


FIGURE A - 12 Flow Curves For Test 1.3, 1.4, 1.5, ADD-1, \& ADD-2 with Glass Formers @ 298 K

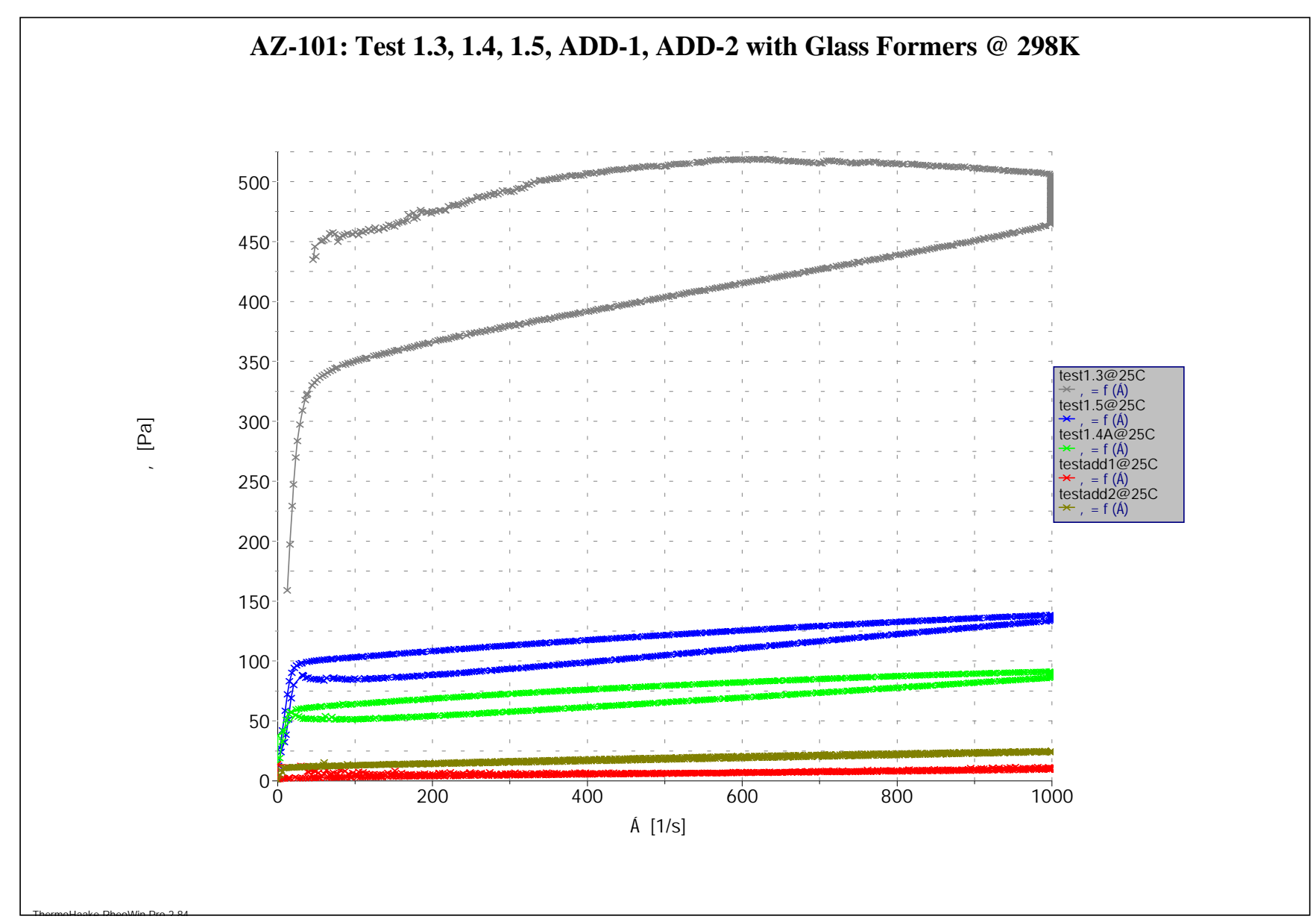


FIGURE A - 13 AZ-101 15 wt.\% I.S. 30-Day Mixing Test

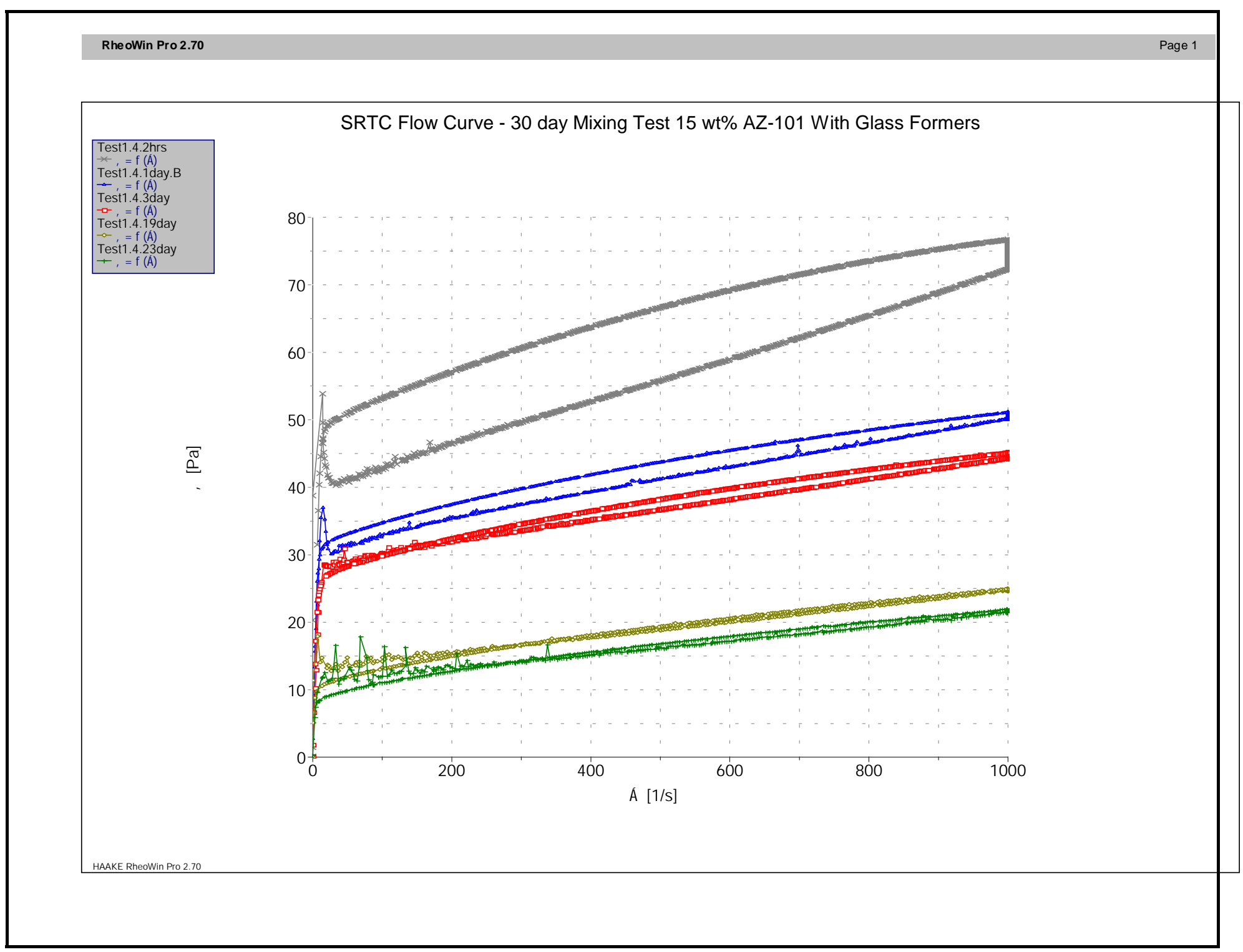


FIGURE A - 14 Flow Curves For Test 2.3, 2.4, 3.5, 2.9, ADD-3, \& ADD-4 @ 298 K

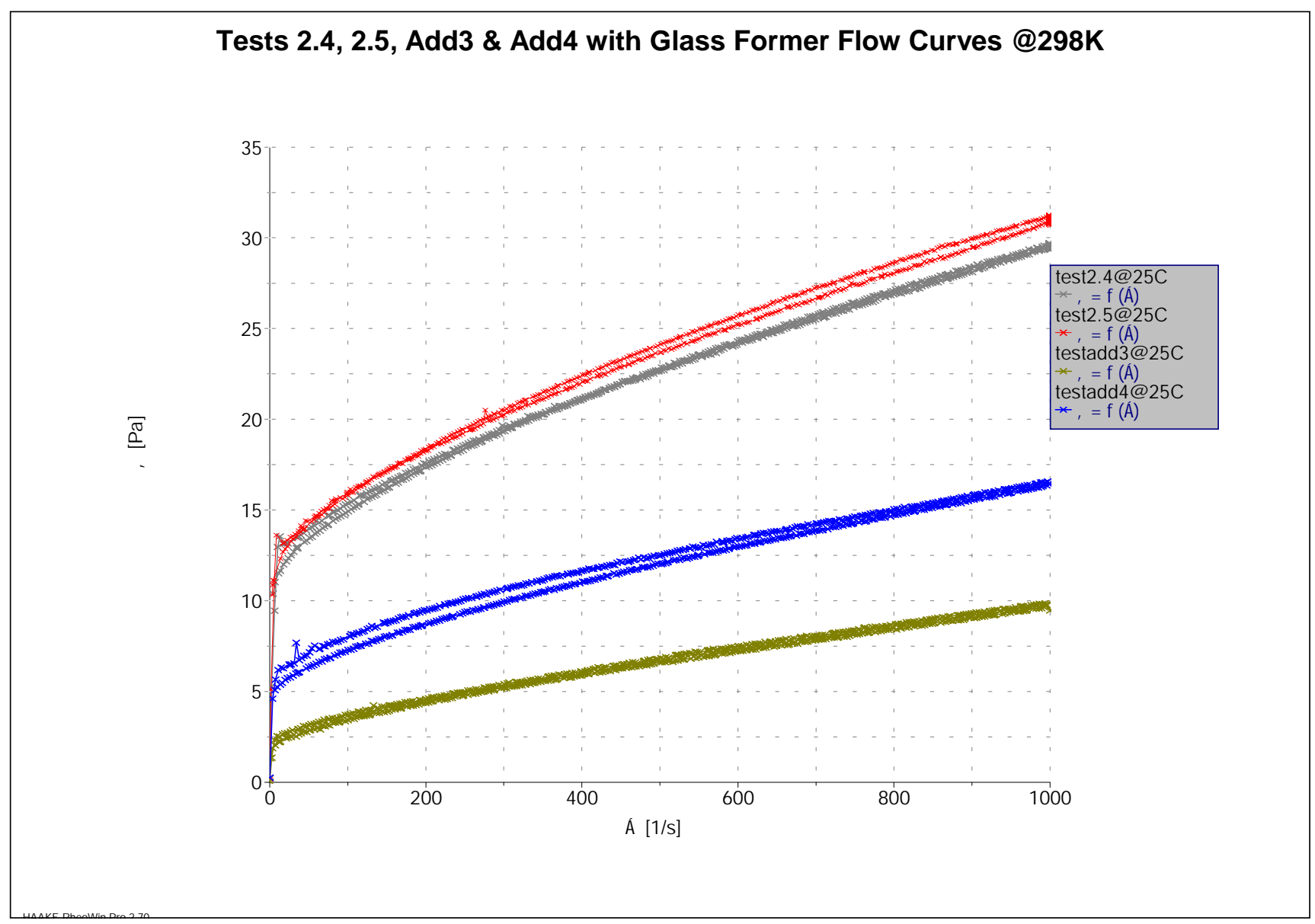


WSRC-TR-2001-00203, Rev. 0

SRT-RPP-2001-00051, Rev. 0 TRPT-24590-01-00001

FIGURE A - 15 Flow Curves for pH-Adjusted Test 1.4 at 298 K

pH Adjusted Test Mixture 1.4 Flow Curves

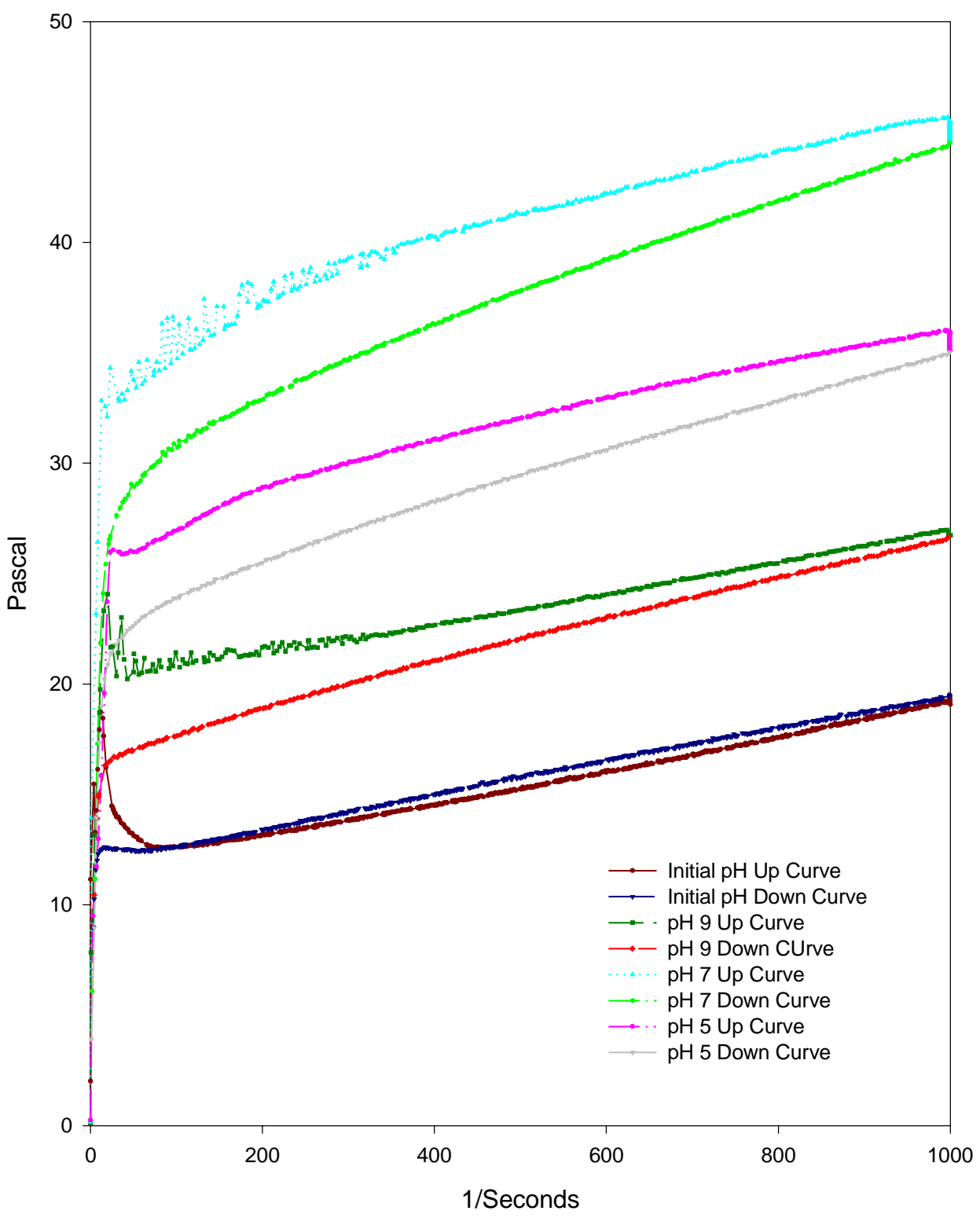


WSRC-TR-2001-00203, Rev. 0

SRT-RPP-2001-00051, Rev. 0 TRPT-24590-01-00001

FIGURE A - 16 Flow Curves for pH-adjusted Test 1.5 at 298 K

pH Adjusted Test Mixture 1.5 Flow Curves

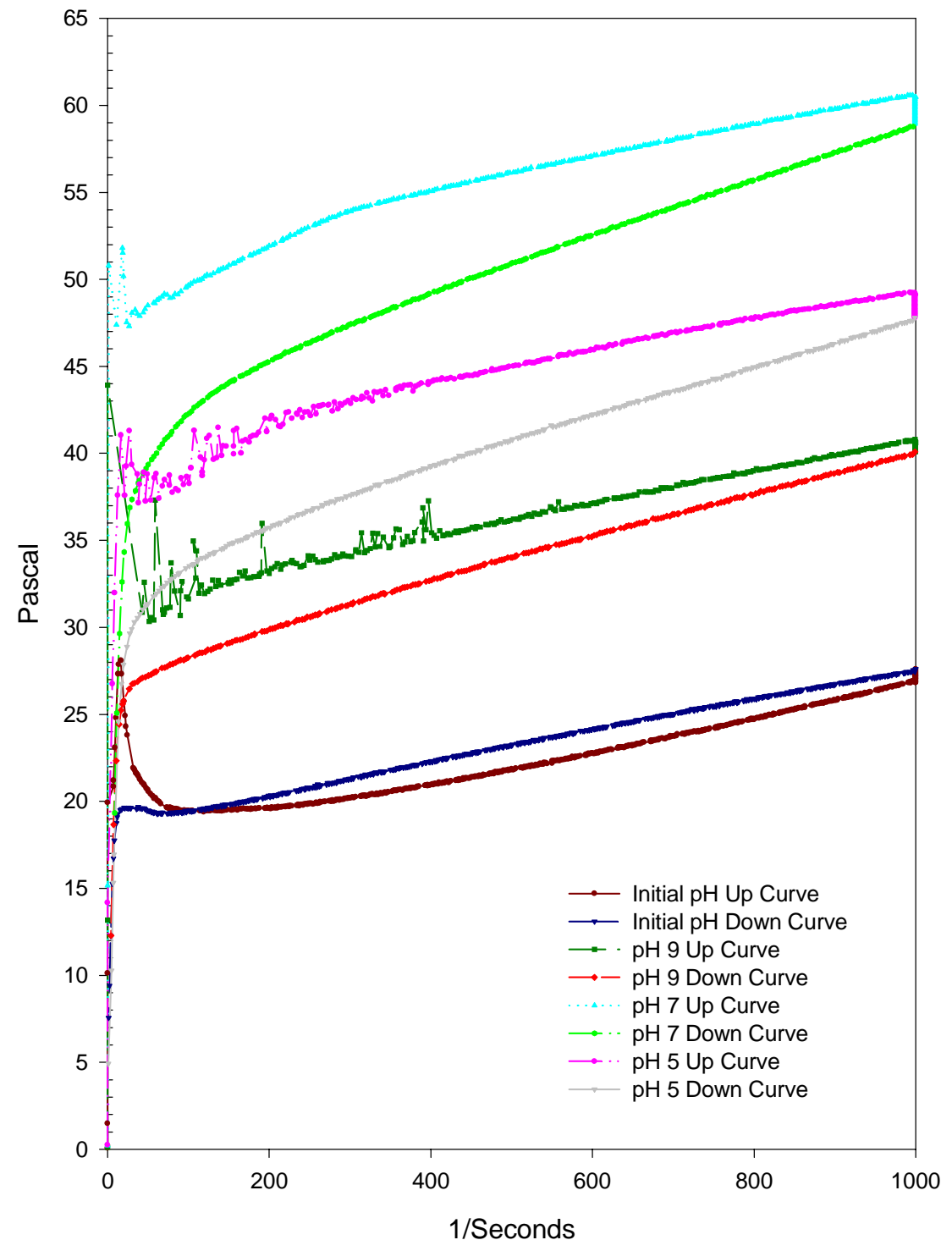


WSRC-TR-2001-00203, Rev. 0

SRT-RPP-2001-00051, Rev. 0

TRPT-24590-01-00001

FIGURE A - 17 Flow Curve for pH adjusted Test 2.3 at 298 K

pH Adjusted Test Mixture 2.3 Flow Curves

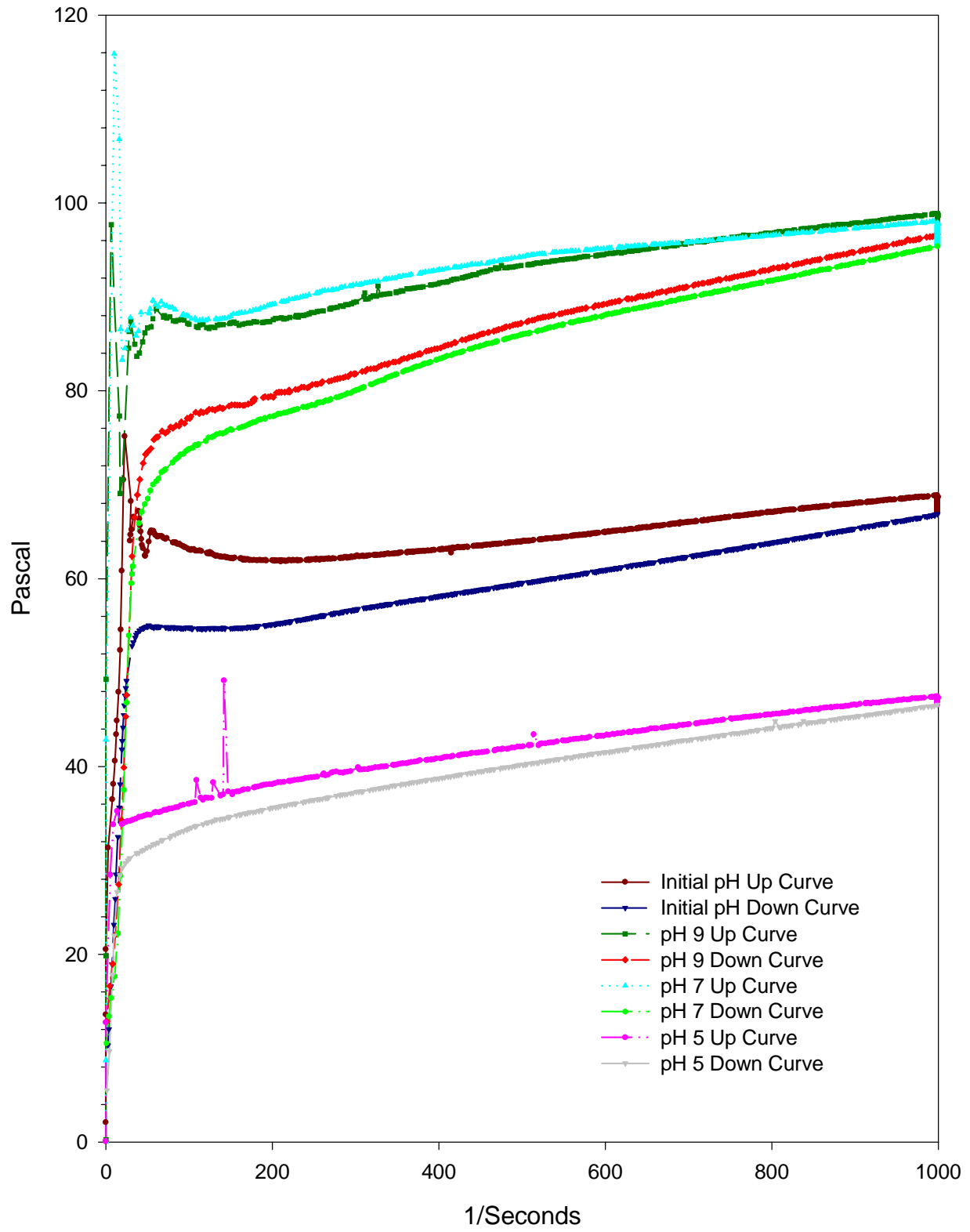


WSRC-TR-2001-00203, Rev. 0

SRT-RPP-2001-00051, Rev. 0

TRPT-24590-01-00001

FIGURE A - 18 Flow Curves for pH-adjusted Test 2.5 at 298 K

pH Adjusted Test Mixture 2.5 Flow Curves

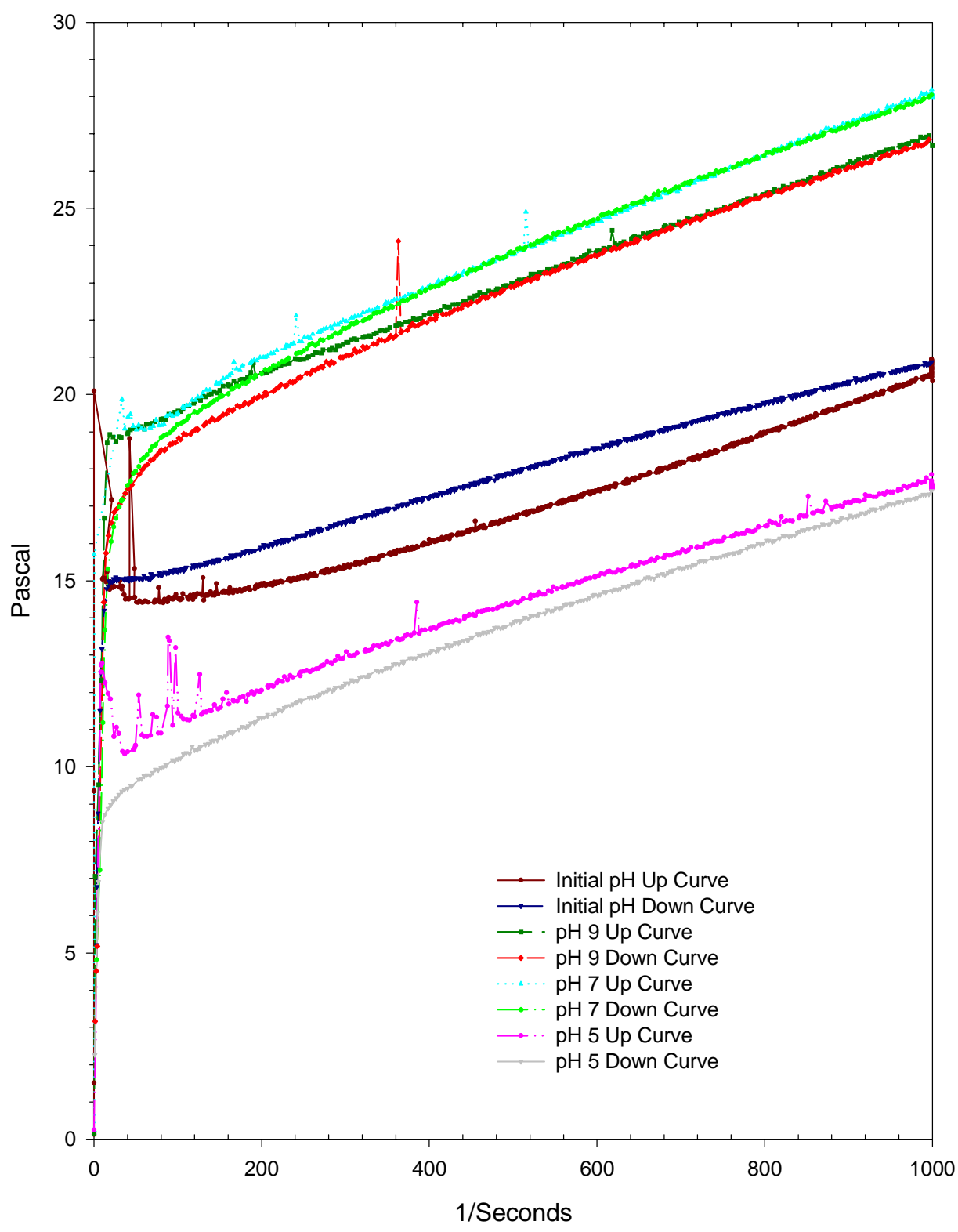


FIGURE A - 19 AZ-101 Sludge Simulant Particle Size Before Shearing

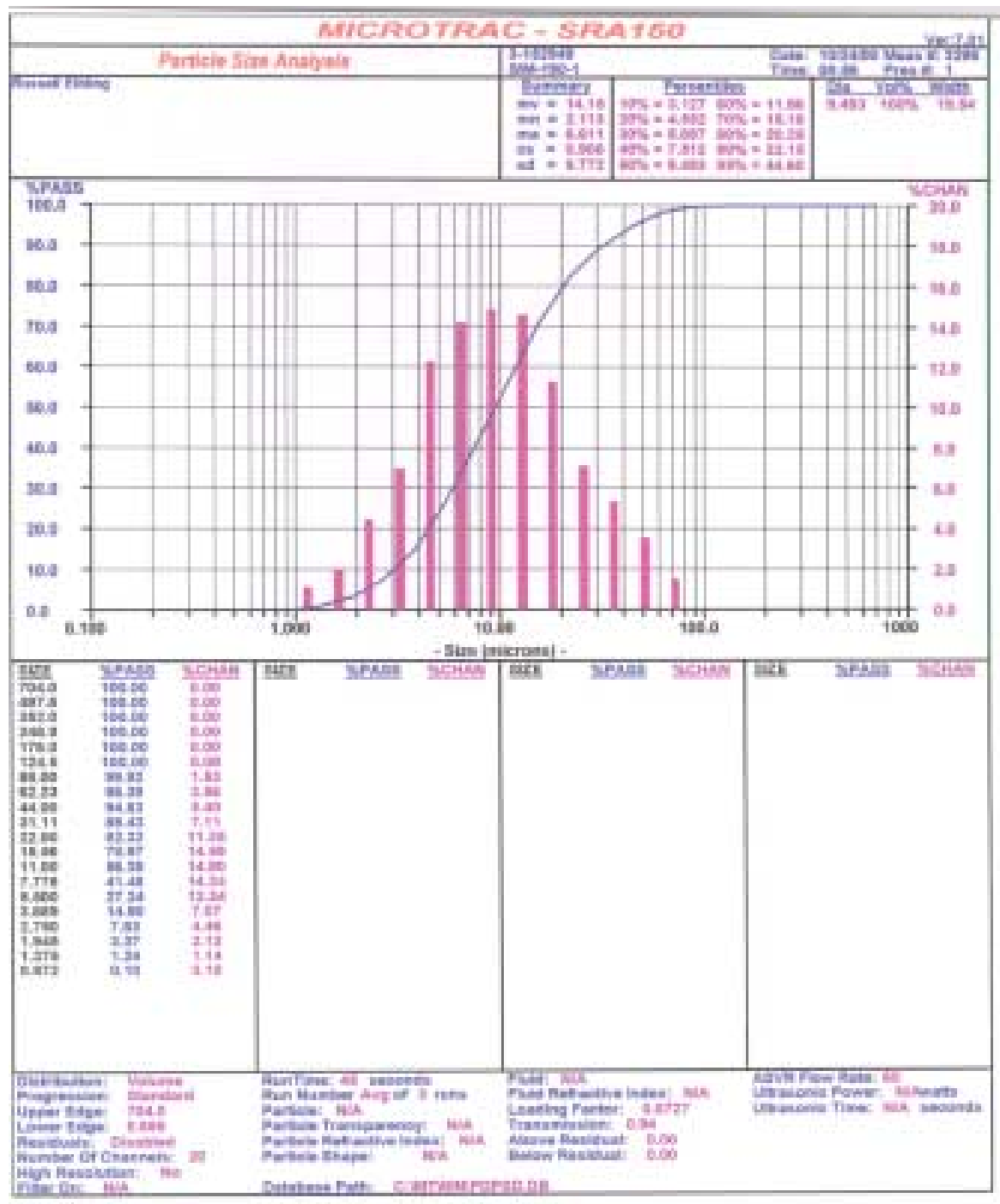

FIGURE A - 20 AZ-101 Sludge Simulant Particle Size After Shearing

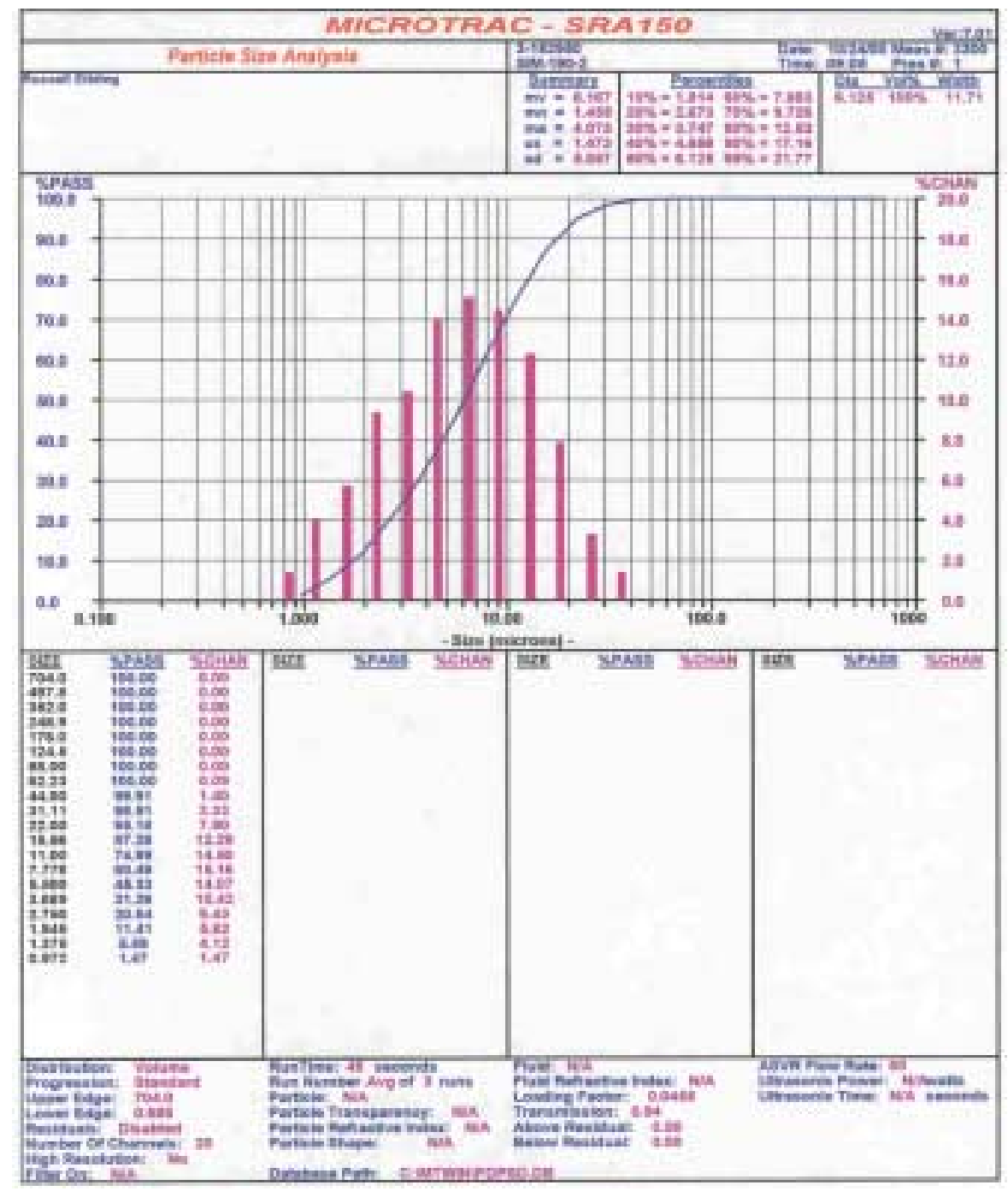


FIGURE A - 21 AZ-102 Sludge Simulant Particle Size Before Shearing

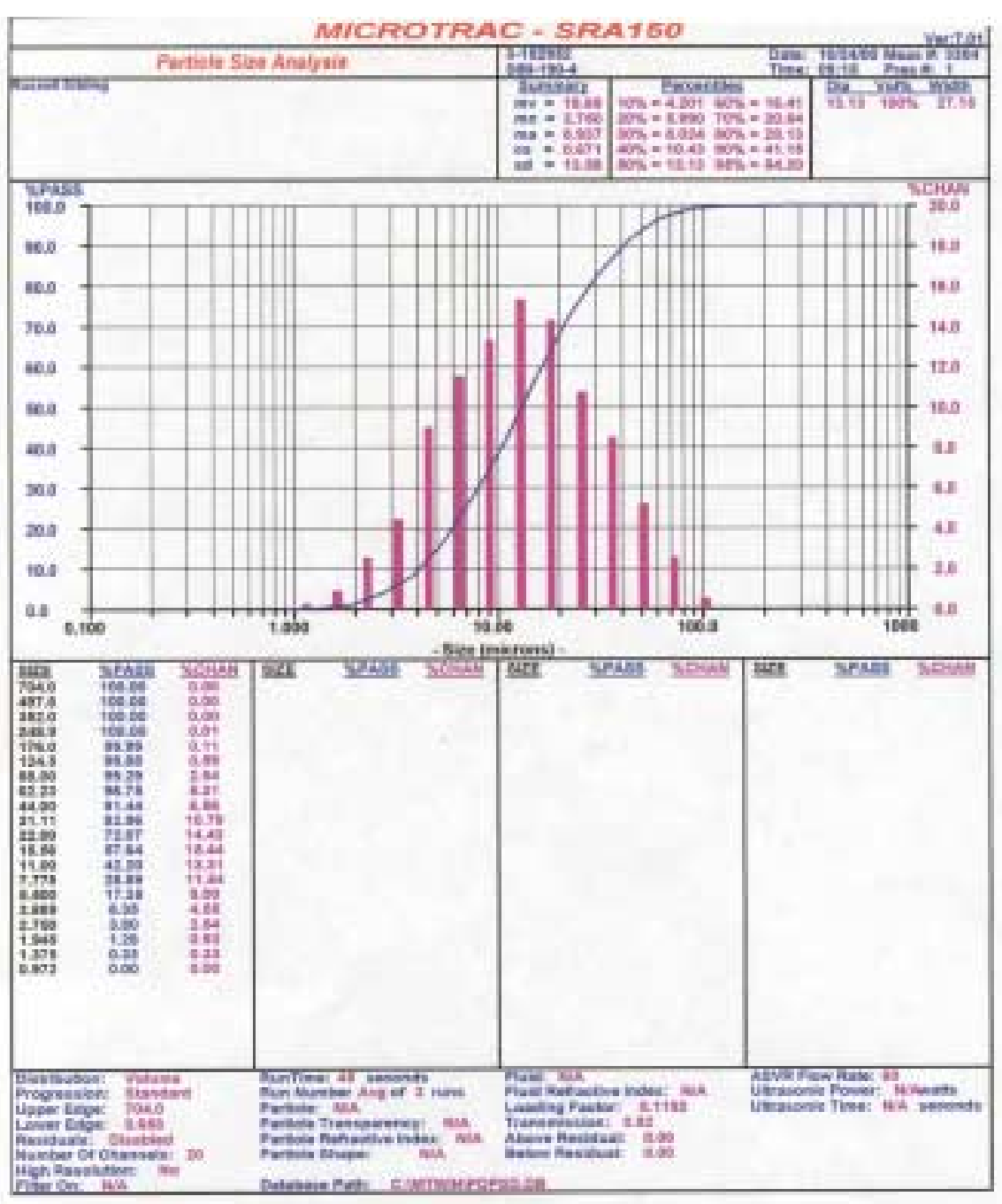

FIGURE A - 22 AZ-102 Sludge Simulant Particle Size After Shearing

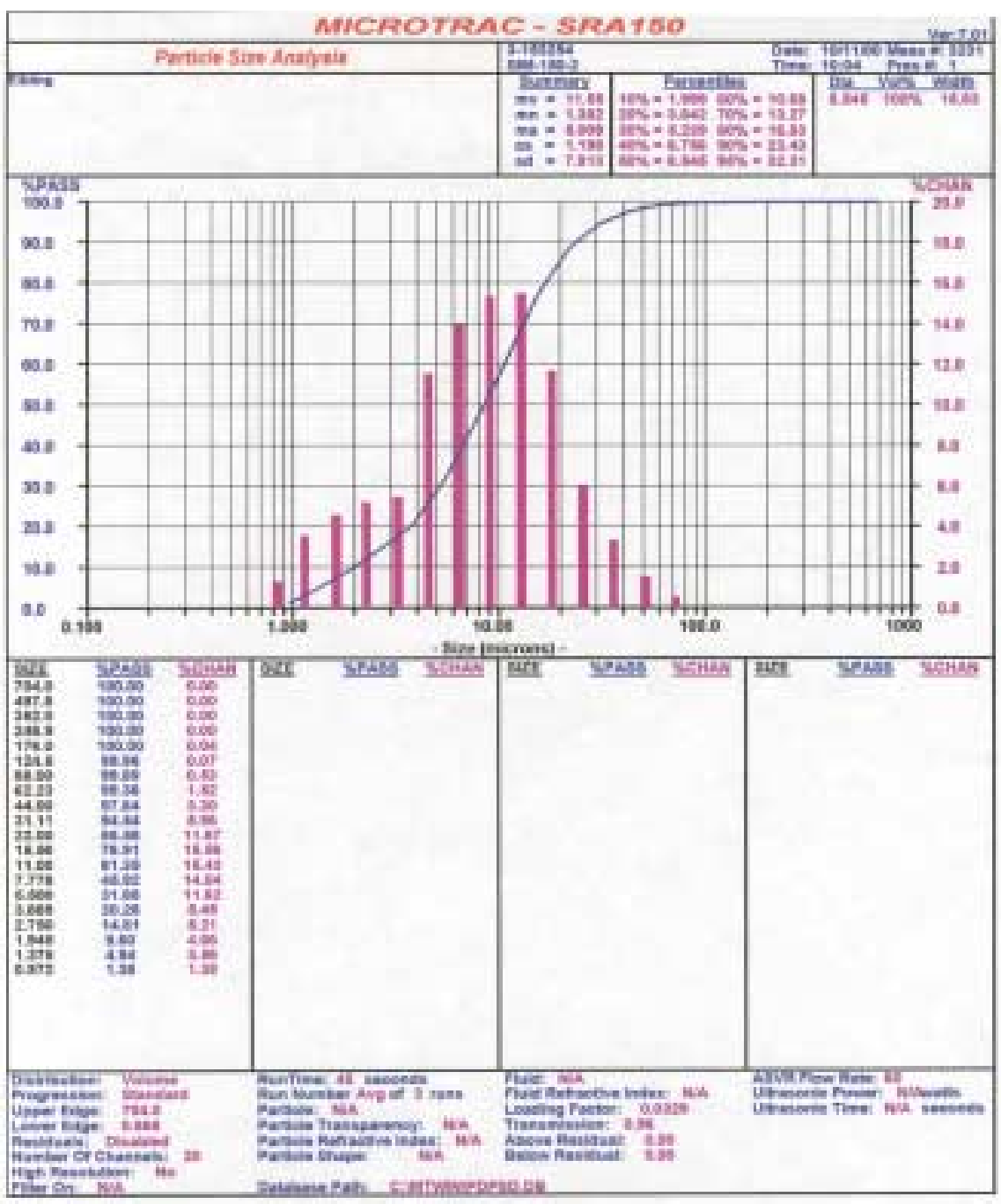


FIGURE A - 23 AN-107 Sr/TRU Prep/Washed Particle Size Before Shearing

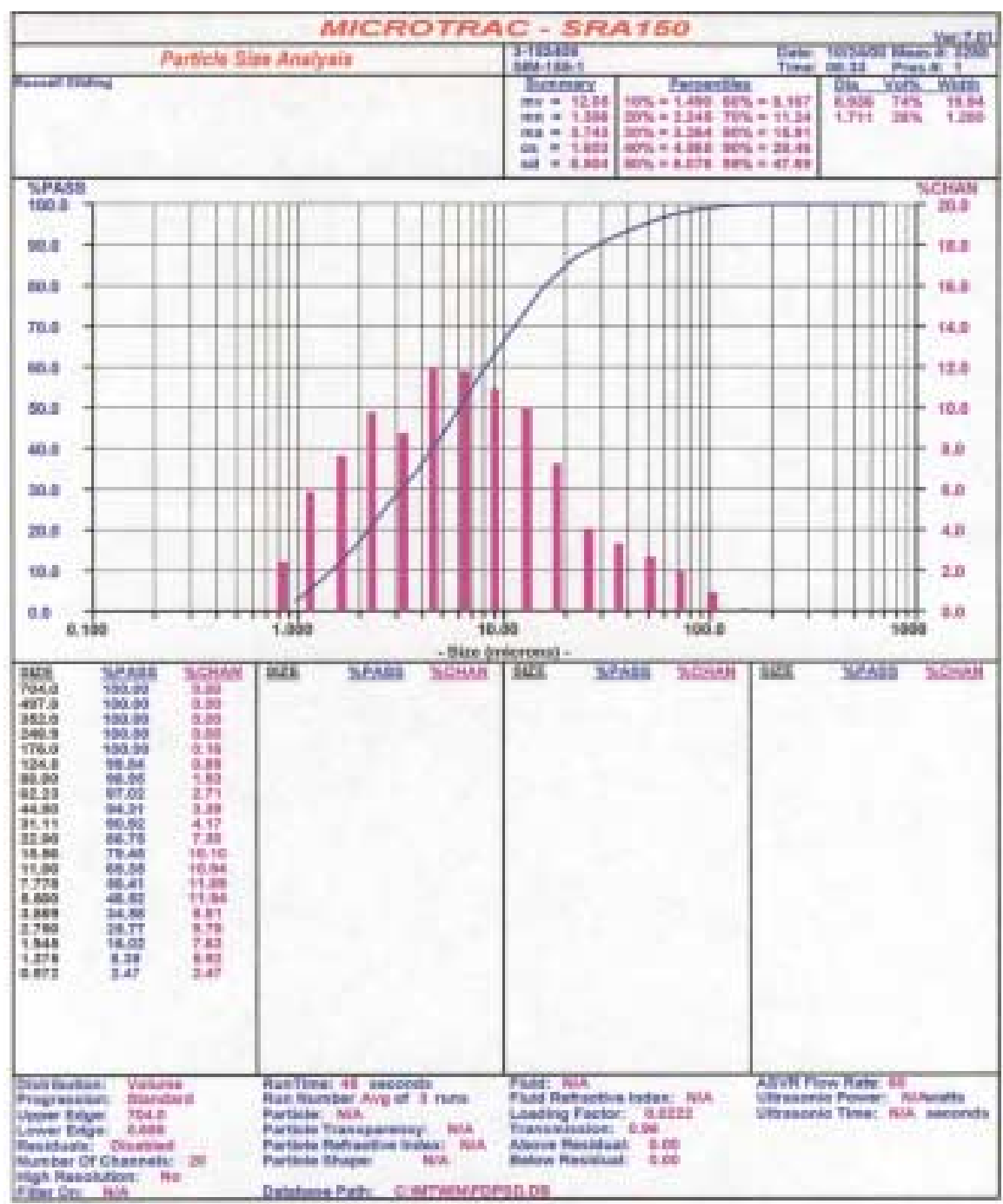

FIGURE A - 24 AN-107 Sr/TRU Prep/Washed Particle Size After Shearing

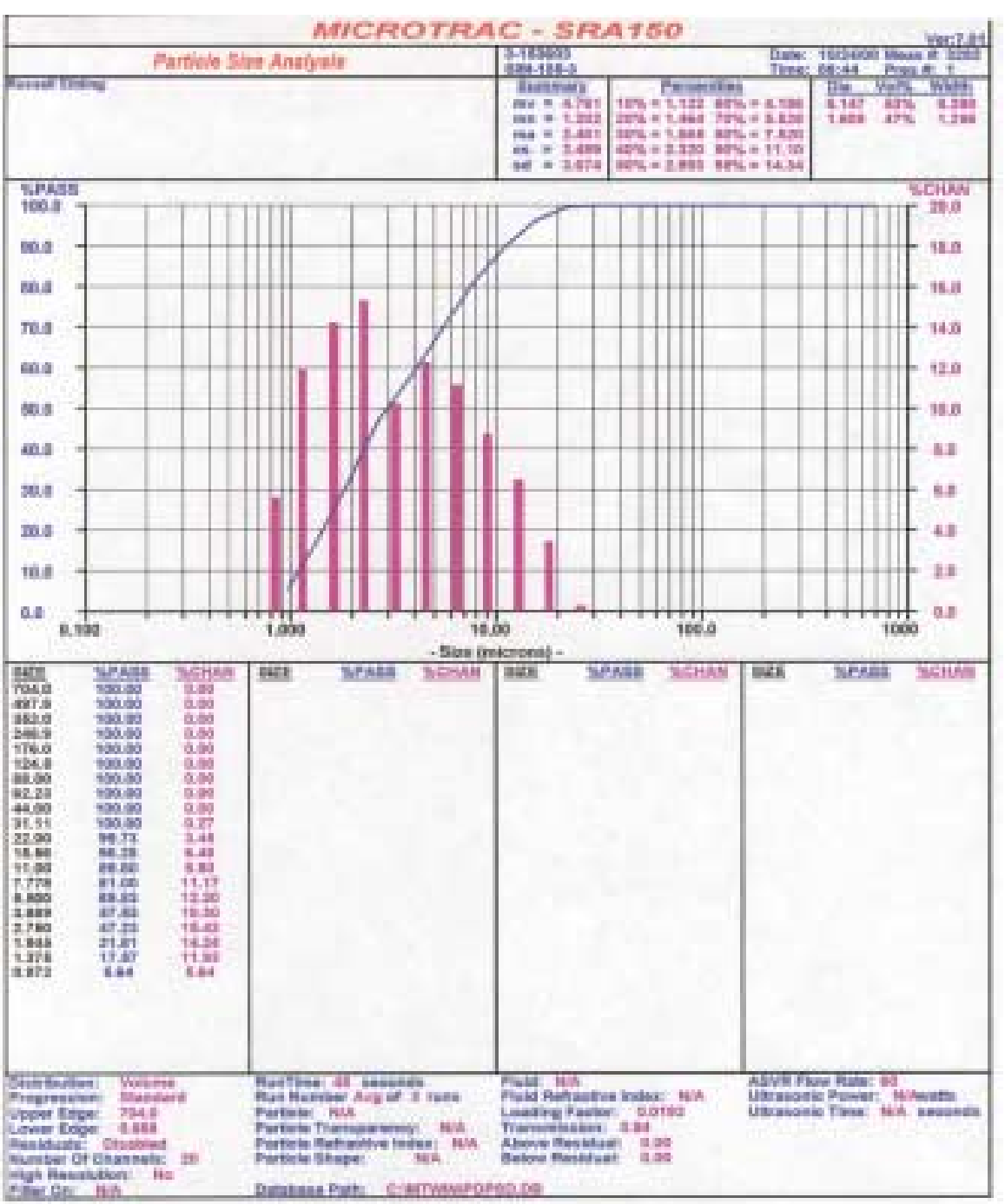


FIGURE A - 25 Particle Size Test No. 1.3, without Glass Formers

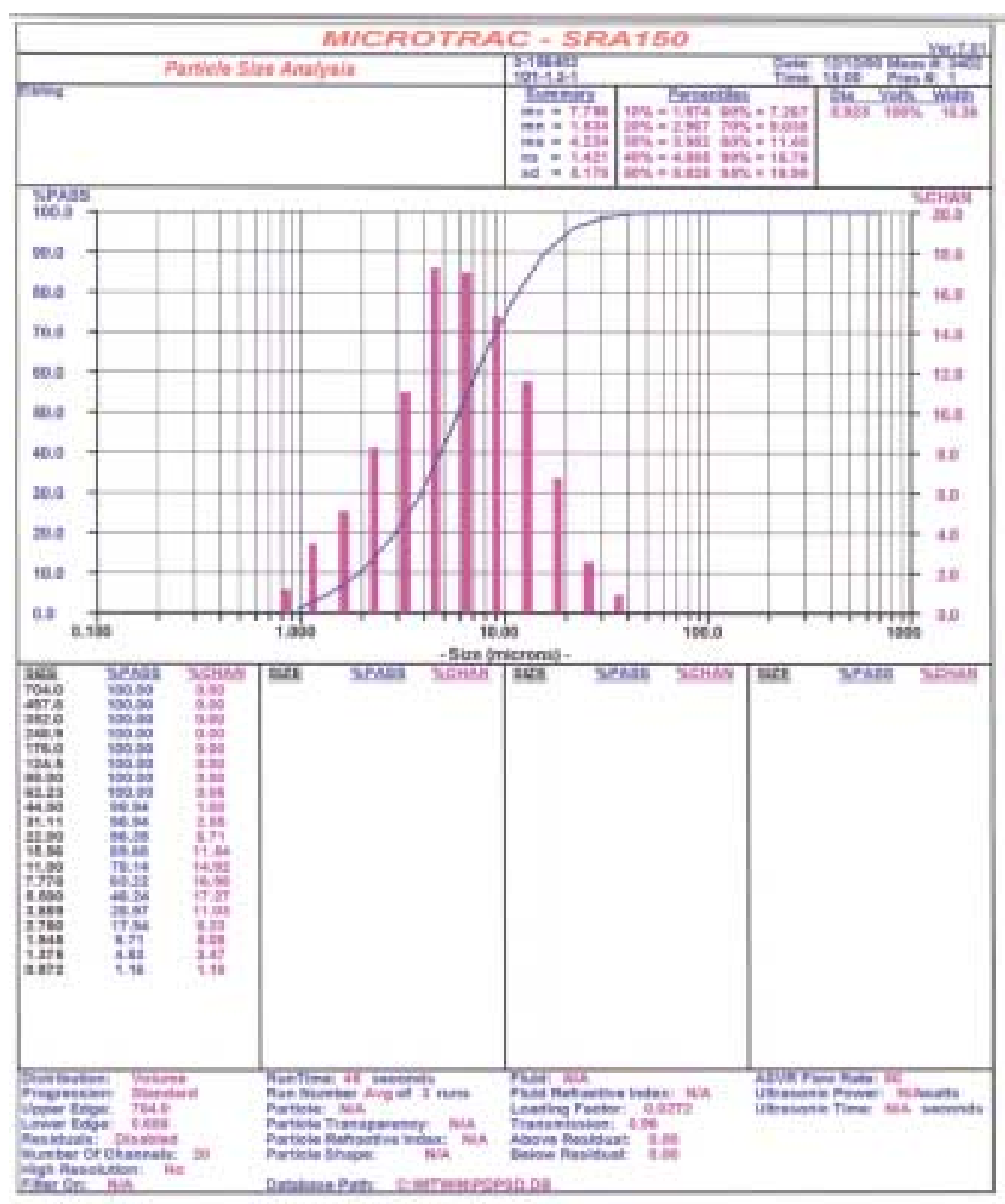

FIGURE A - 26 Particle Size Test No. 1.3, with Glass Formers

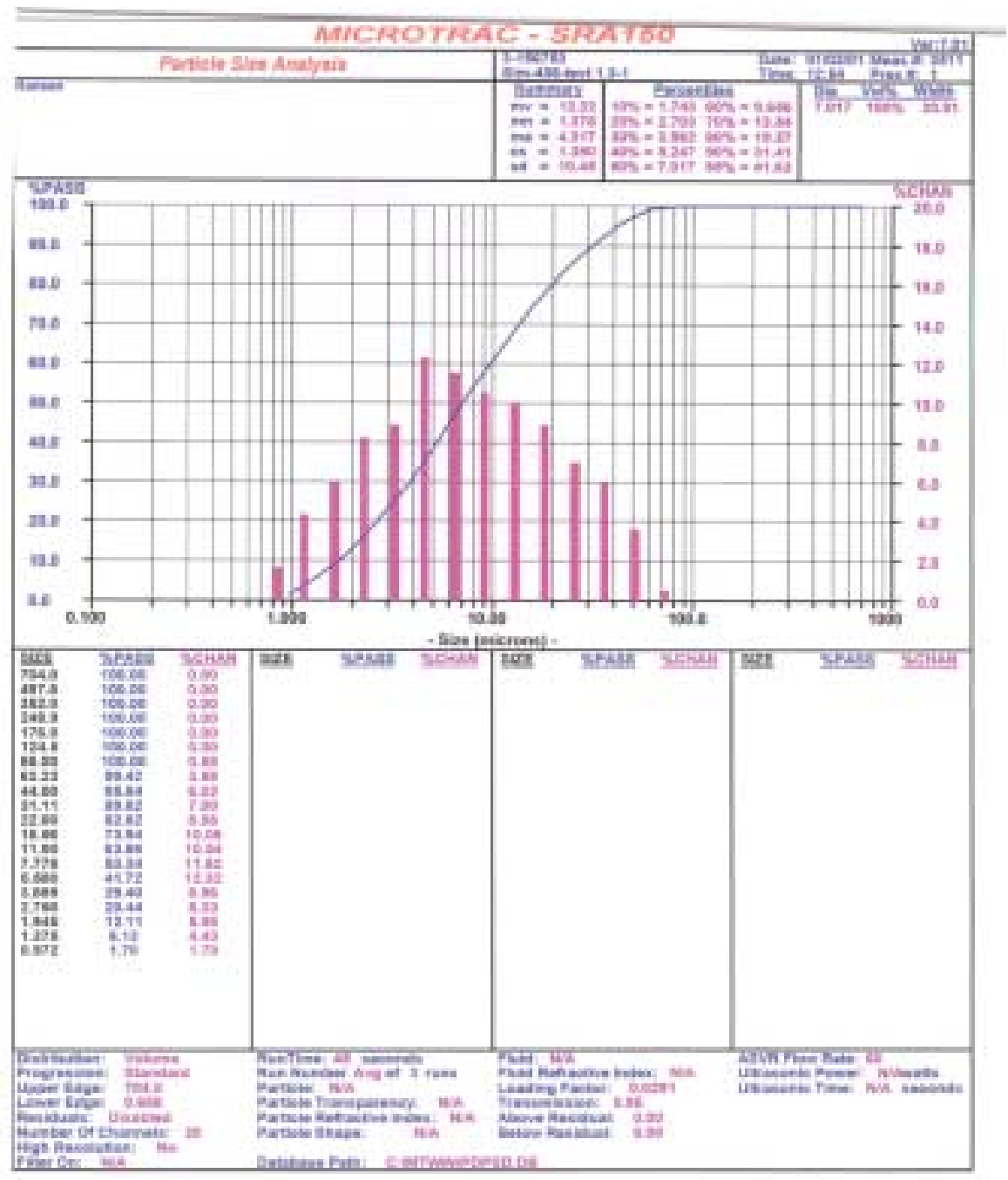


WSRC-TR-2001-00203, Rev. 0

SRT-RPP-2001-00051, Rev. 0 TRPT-24590-01-00001

FIGURE A - 27 Particle Size Test No. 1.4, without Glass Formers

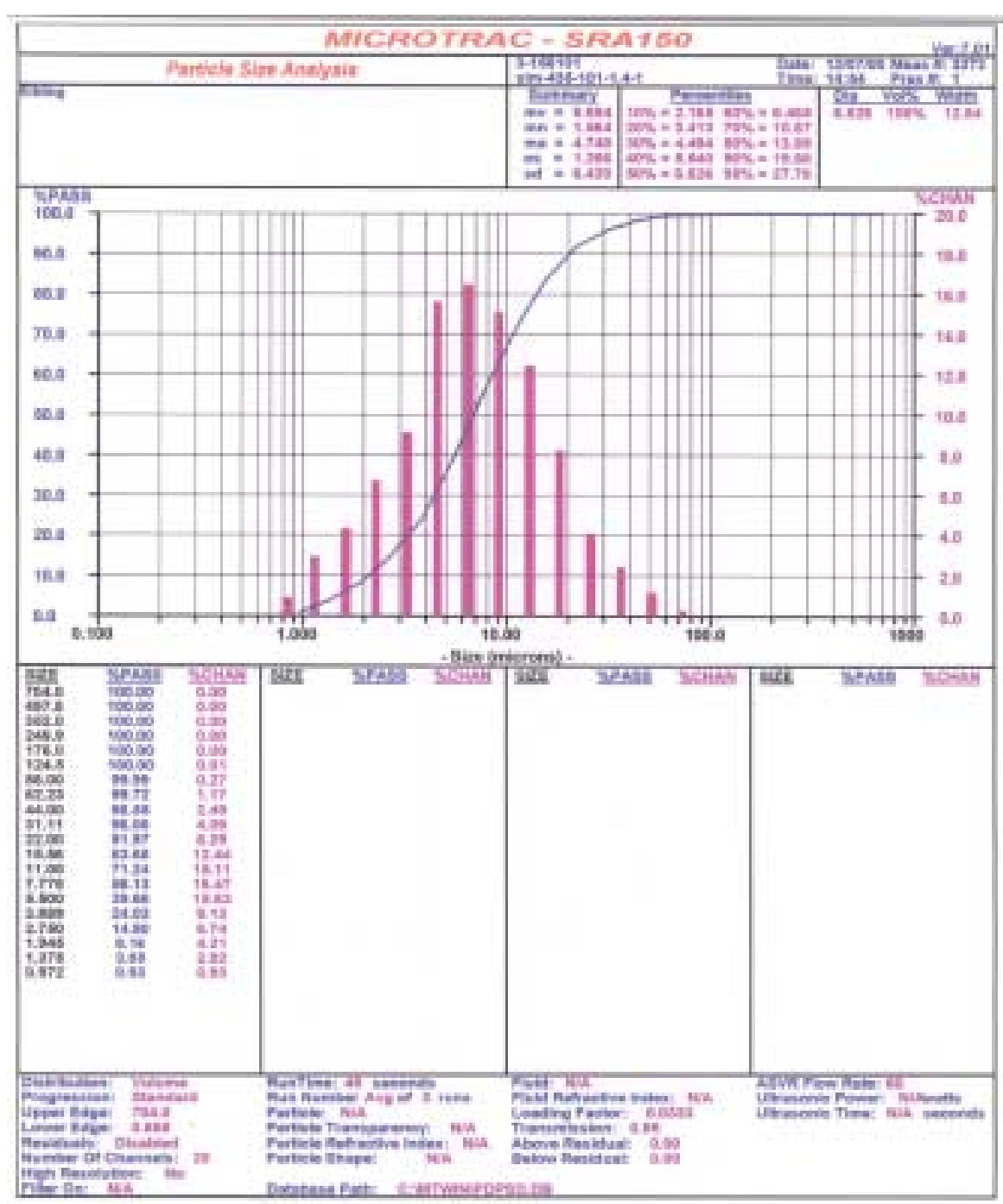

FIGURE A - 28 Particle Size Test No. 1.4, with Glass Formers

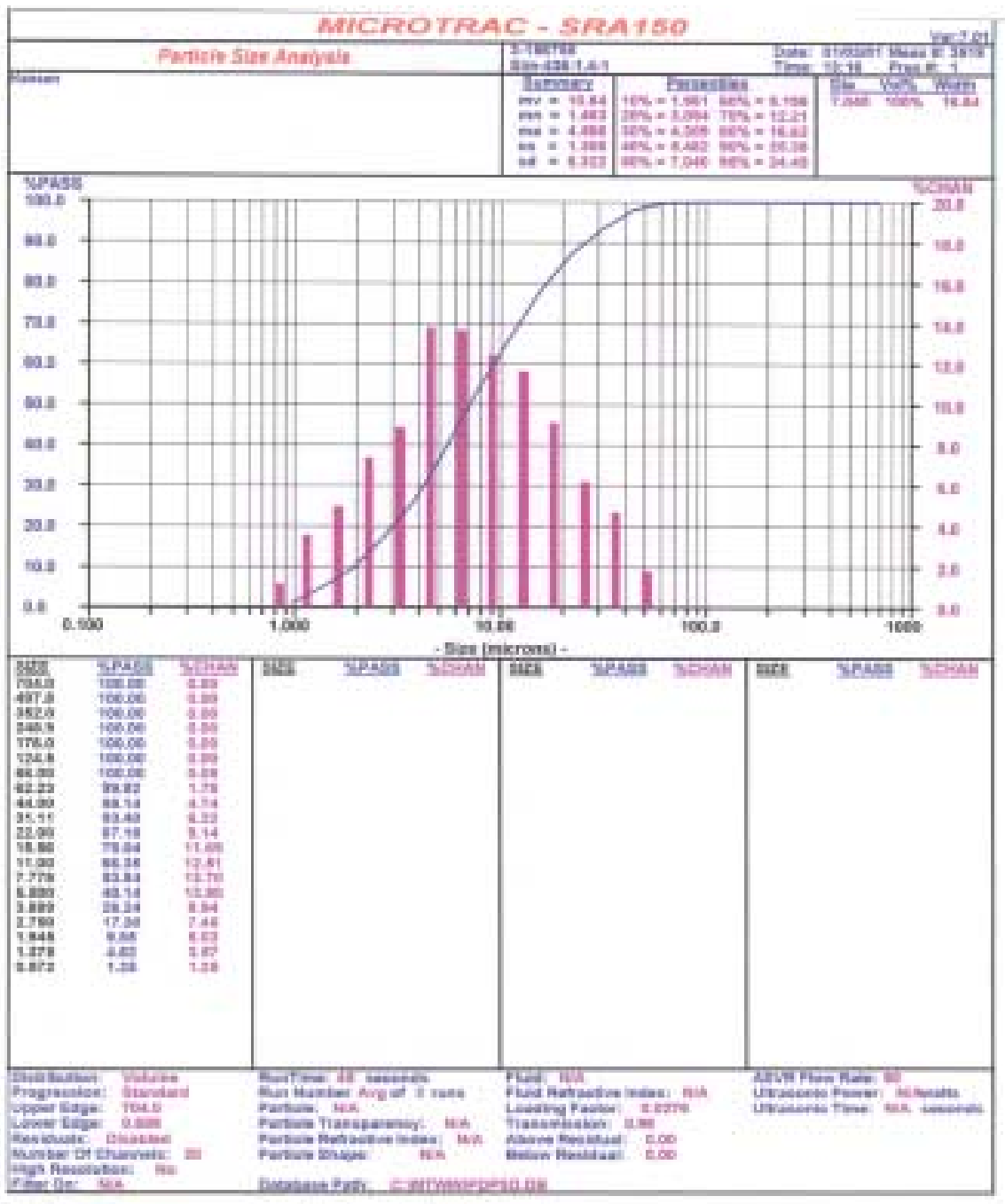


FIGURE A - 29 Particle Size Test No. 1.5, without Glass Formers

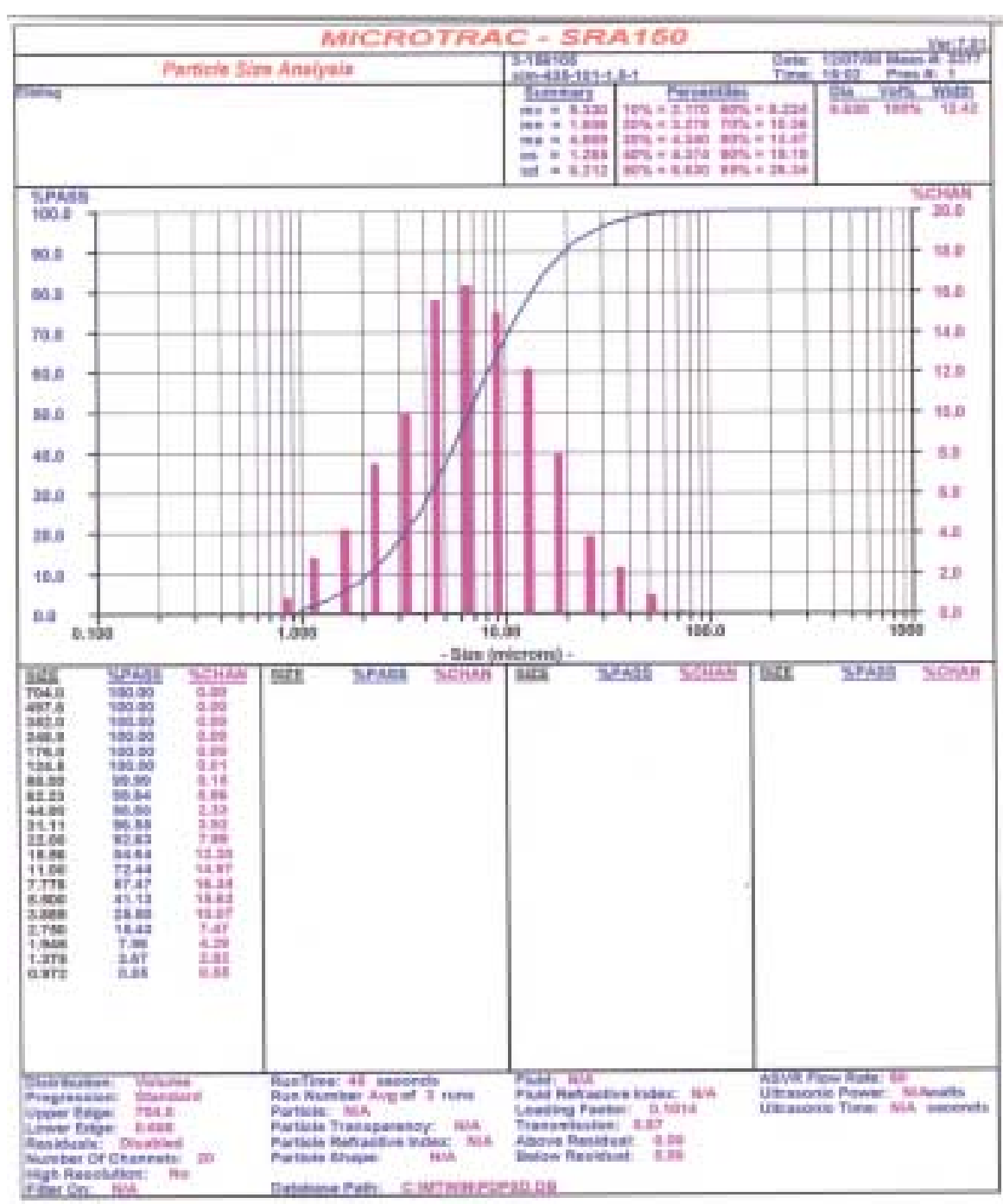

FIGURE A - 30 Particle Size Test No. 1.5, with Glass Formers

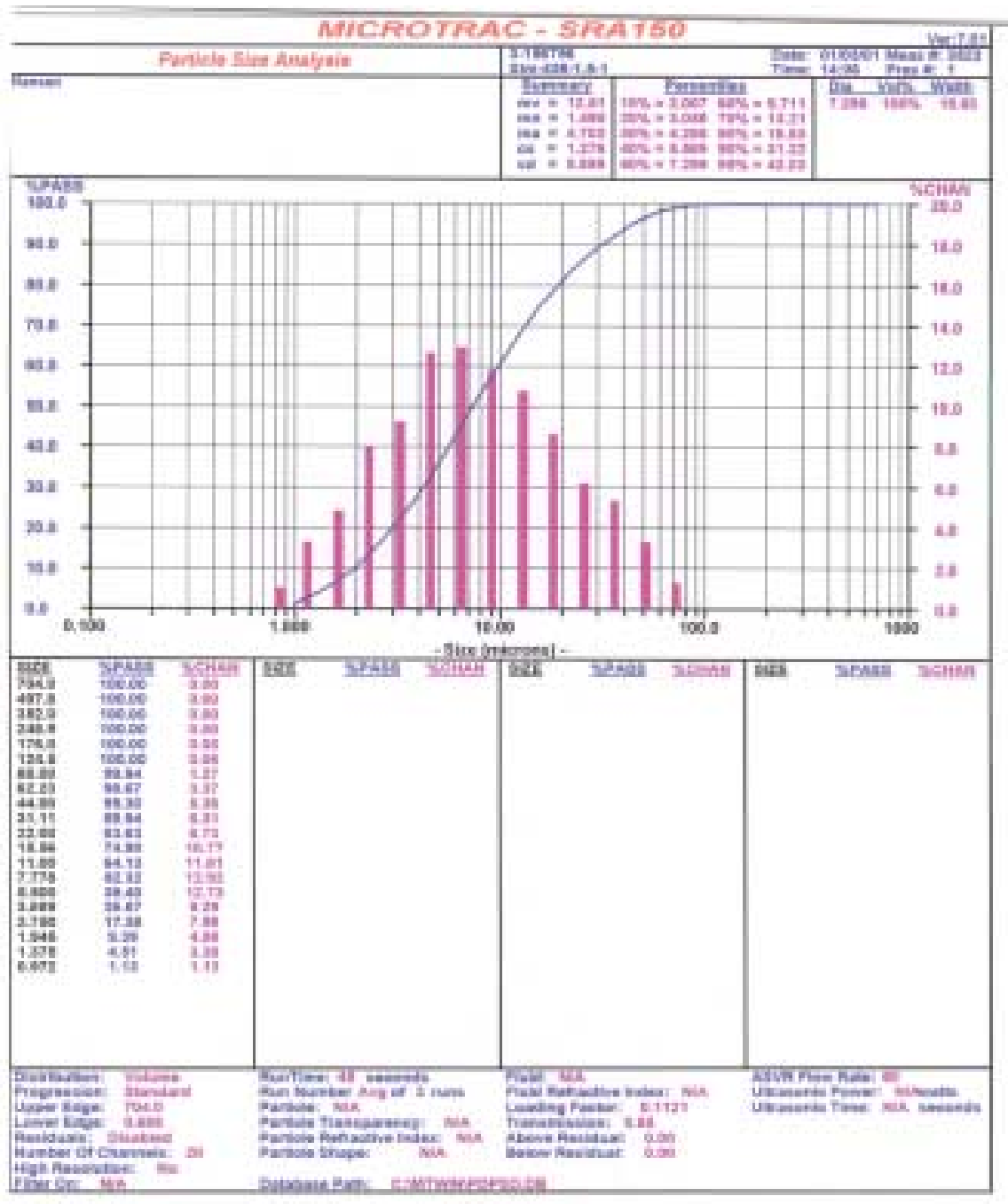


WSRC-TR-2001-00203, Rev. 0

FIGURE A - 31 Particle Size Test No. ADD-1, without Glass Formers

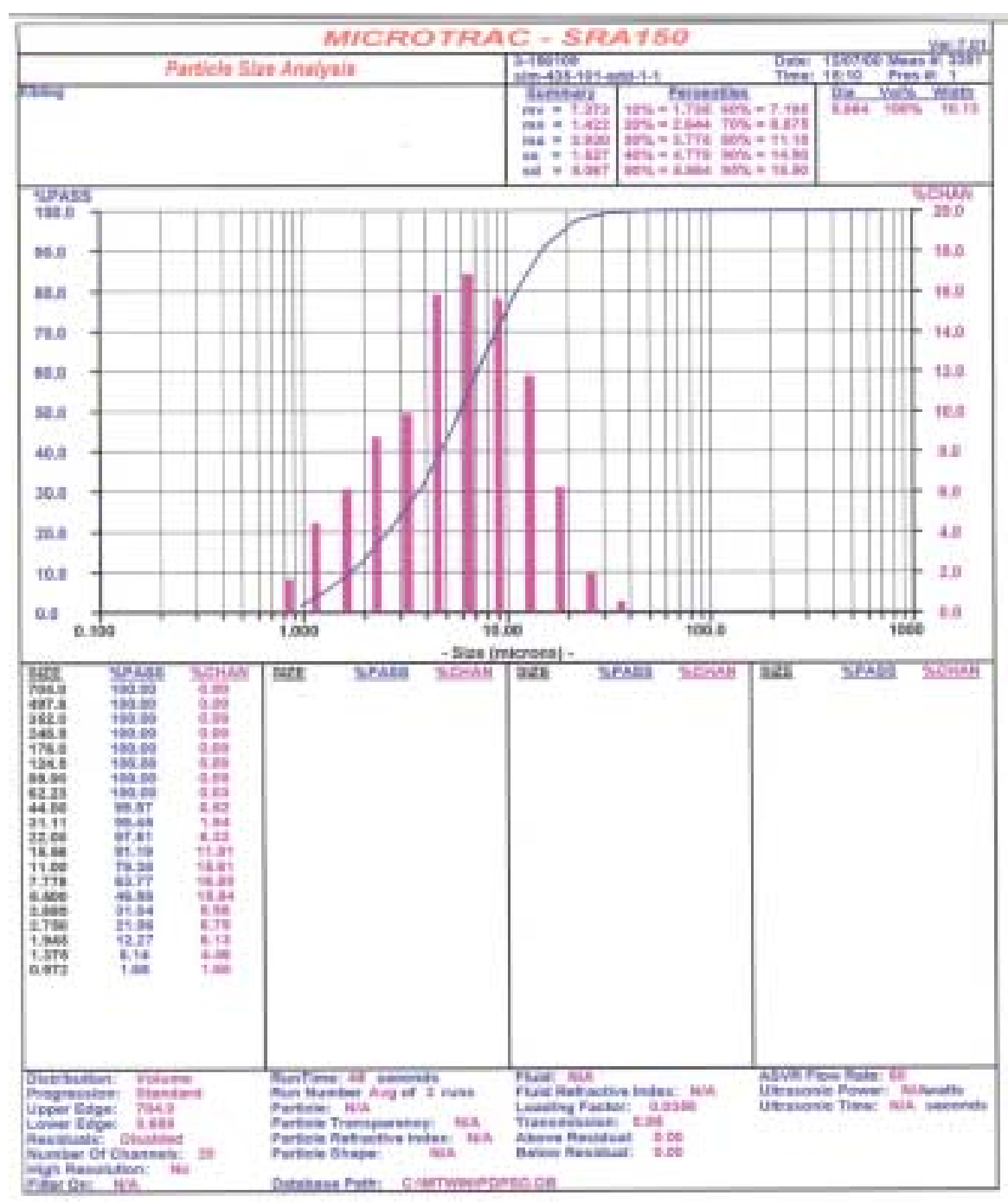

FIGURE A - 32 Particle Size Test No. ADD-1, with Glass Formers

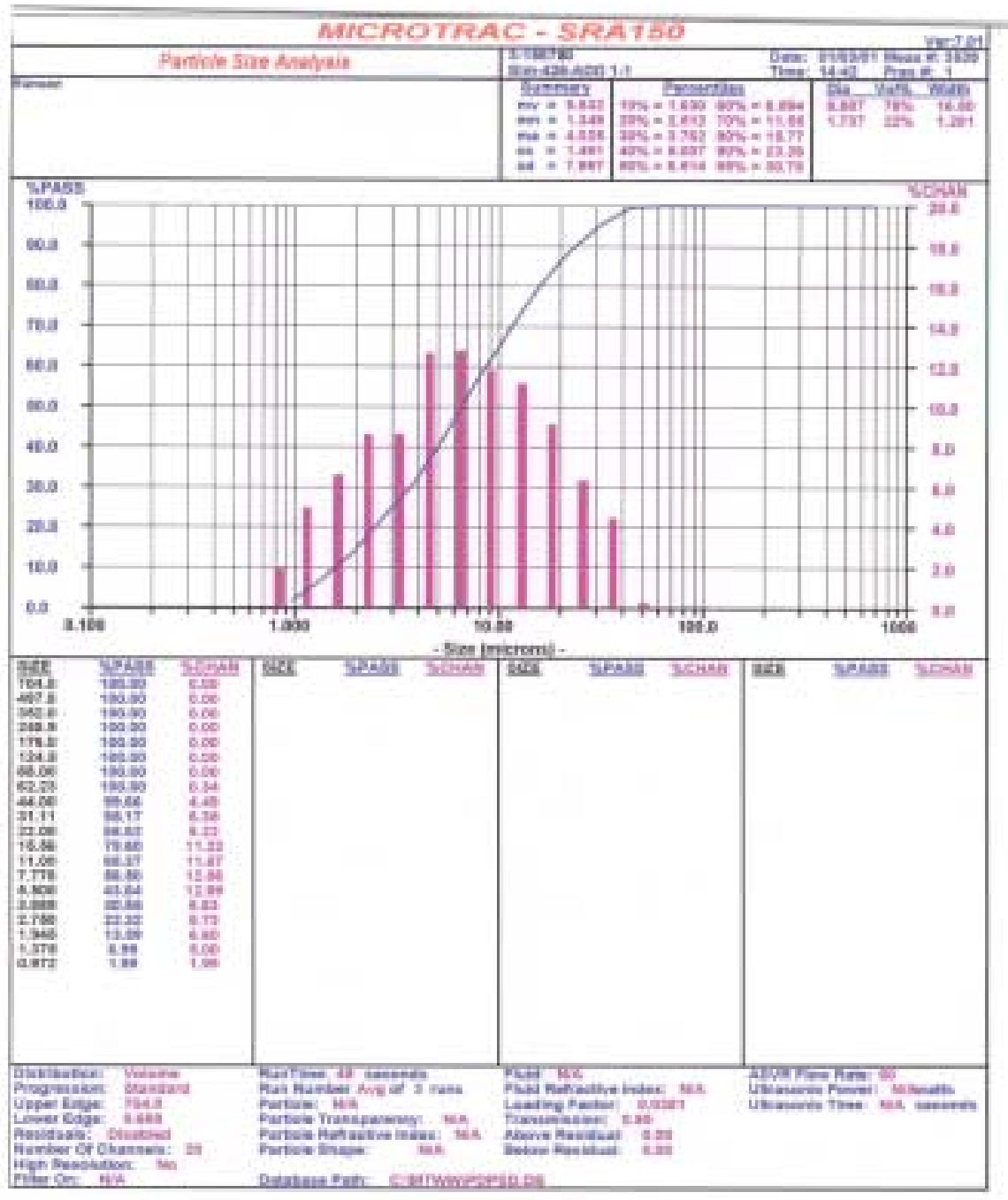


WSRC-TR-2001-00203, Rev. 0

FIGURE A - 33 Particle Size Test No. ADD-2, without Glass Formers

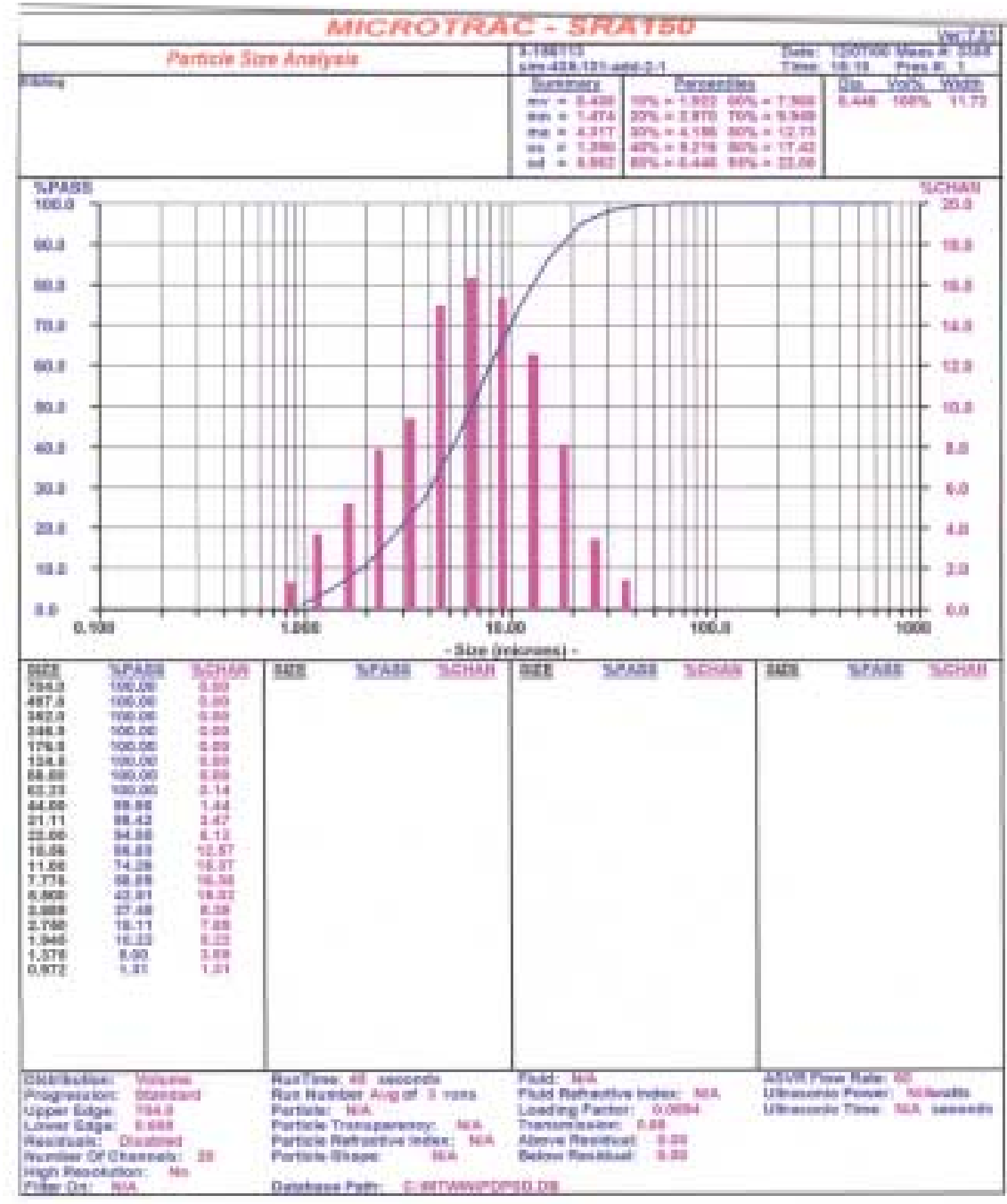

FIGURE A - 34 Particle Size Test No. ADD-2, with Glass Formers

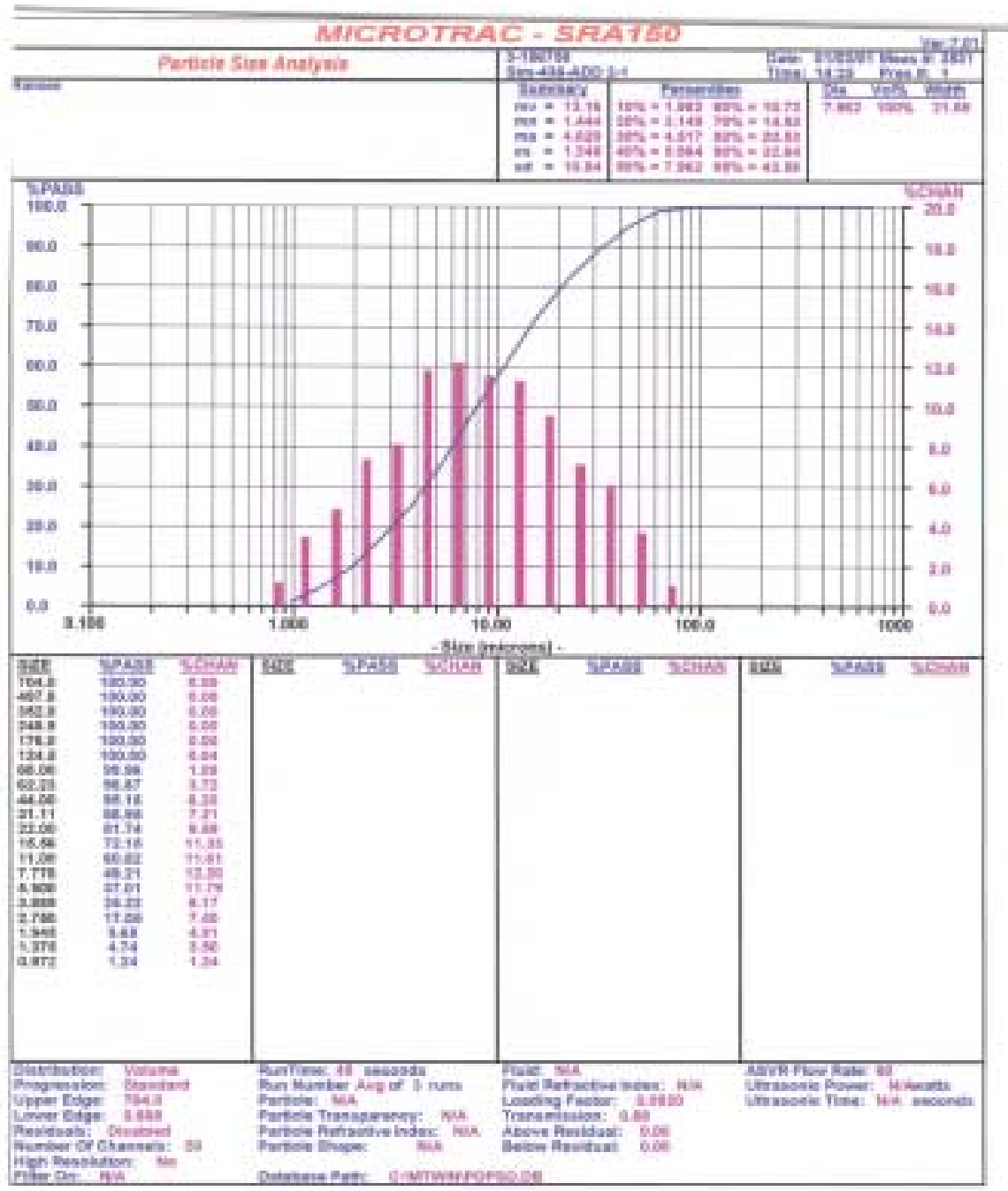


FIGURE A - 35 Particle Size Test No. 2.3, without Glass Formers

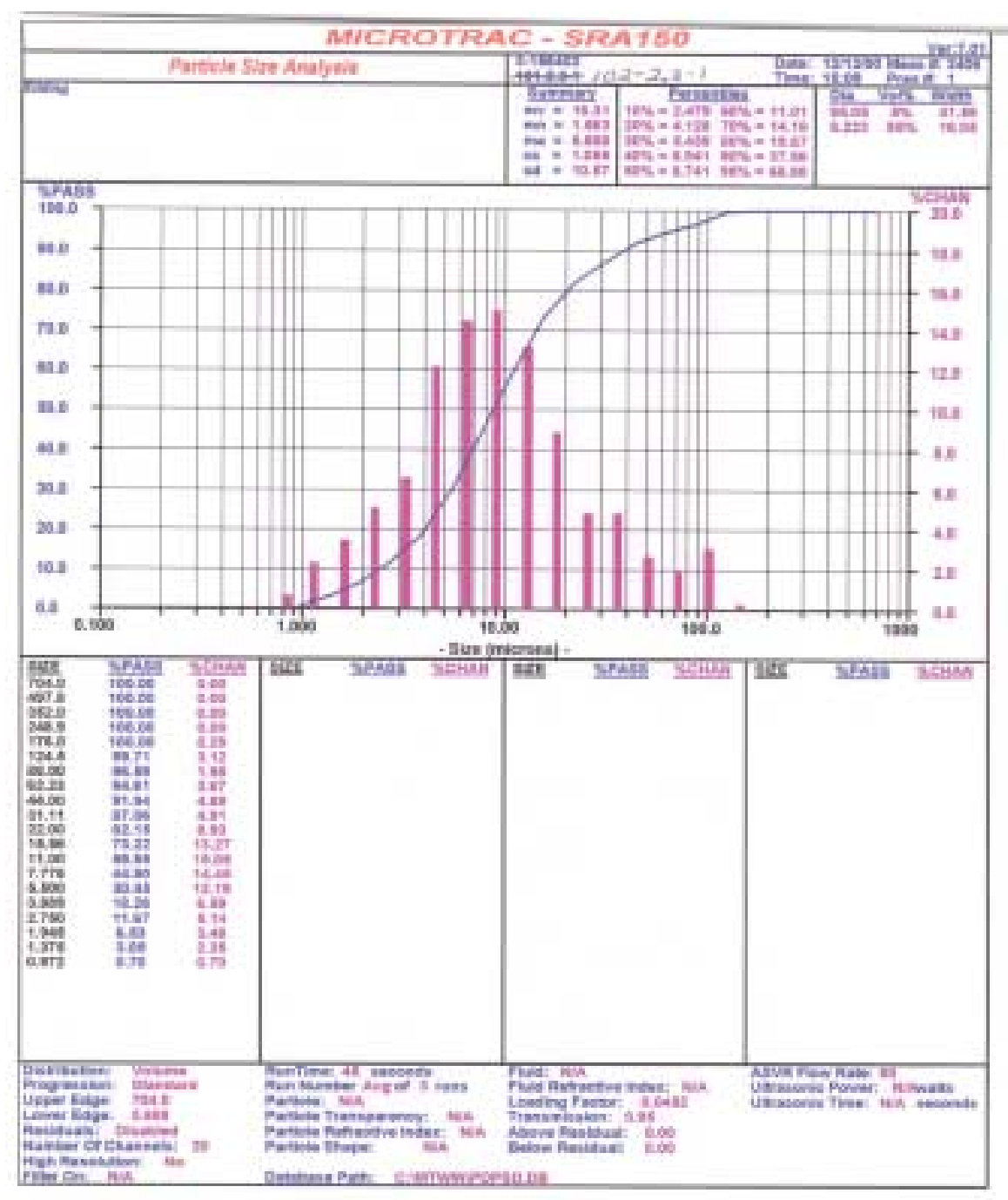

FIGURE A - 36 Particle Size Test No. 2.3, with Glass Formers

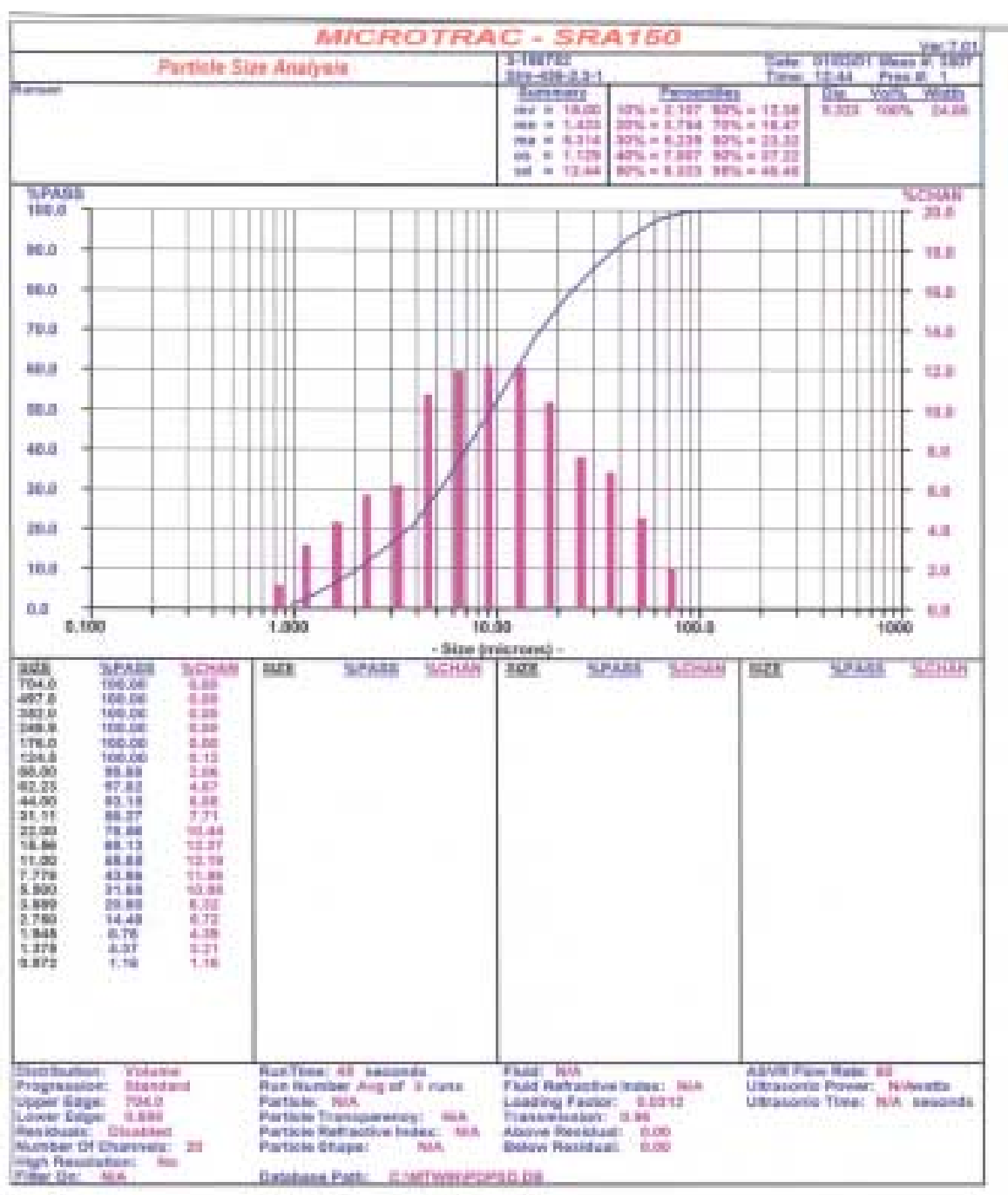


FIGURE A - 37 Particle Size Test No. 2.4, without Glass Formers

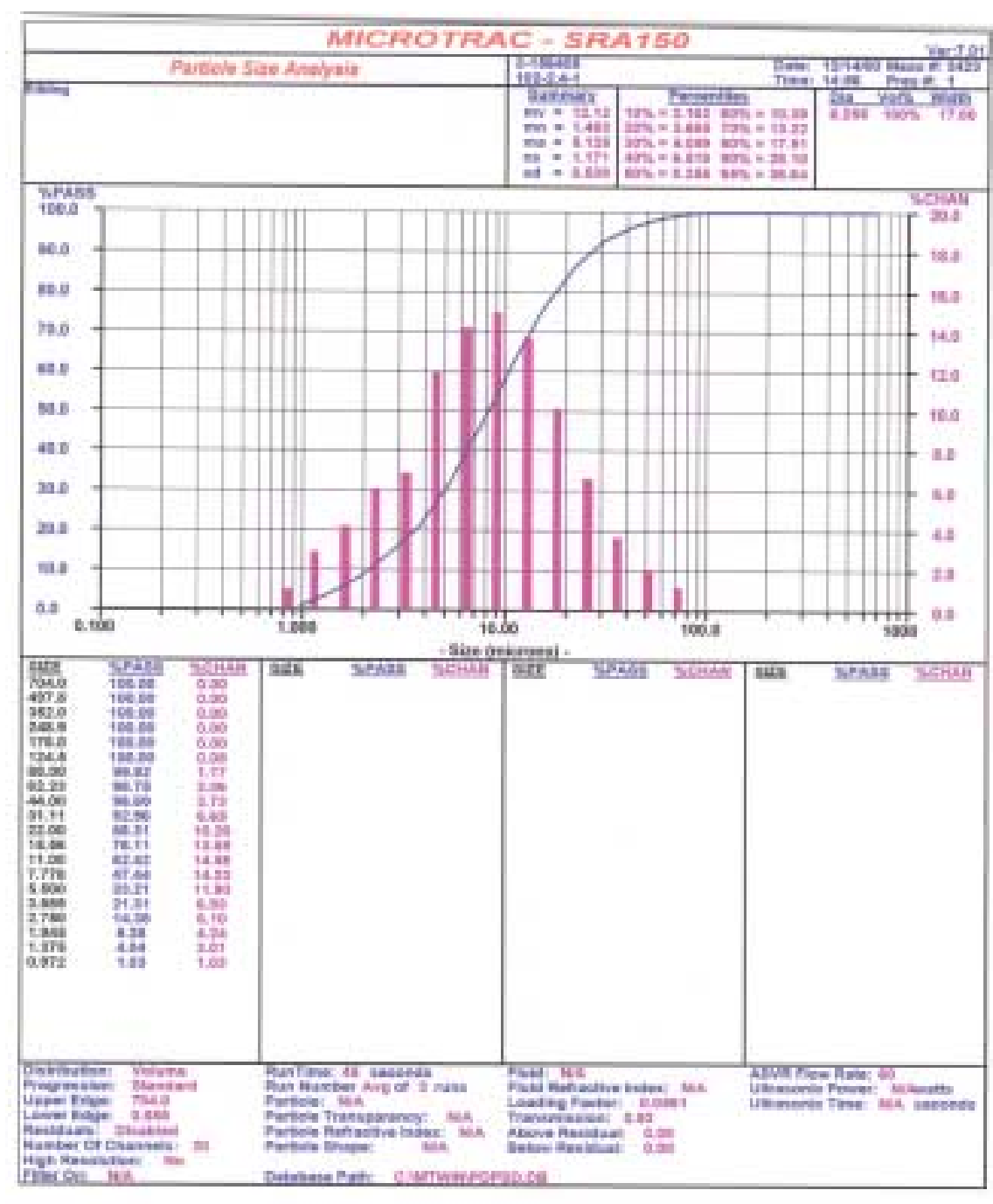

FIGURE A - 38 Particle Size Test No. 2.4, with Glass Formers

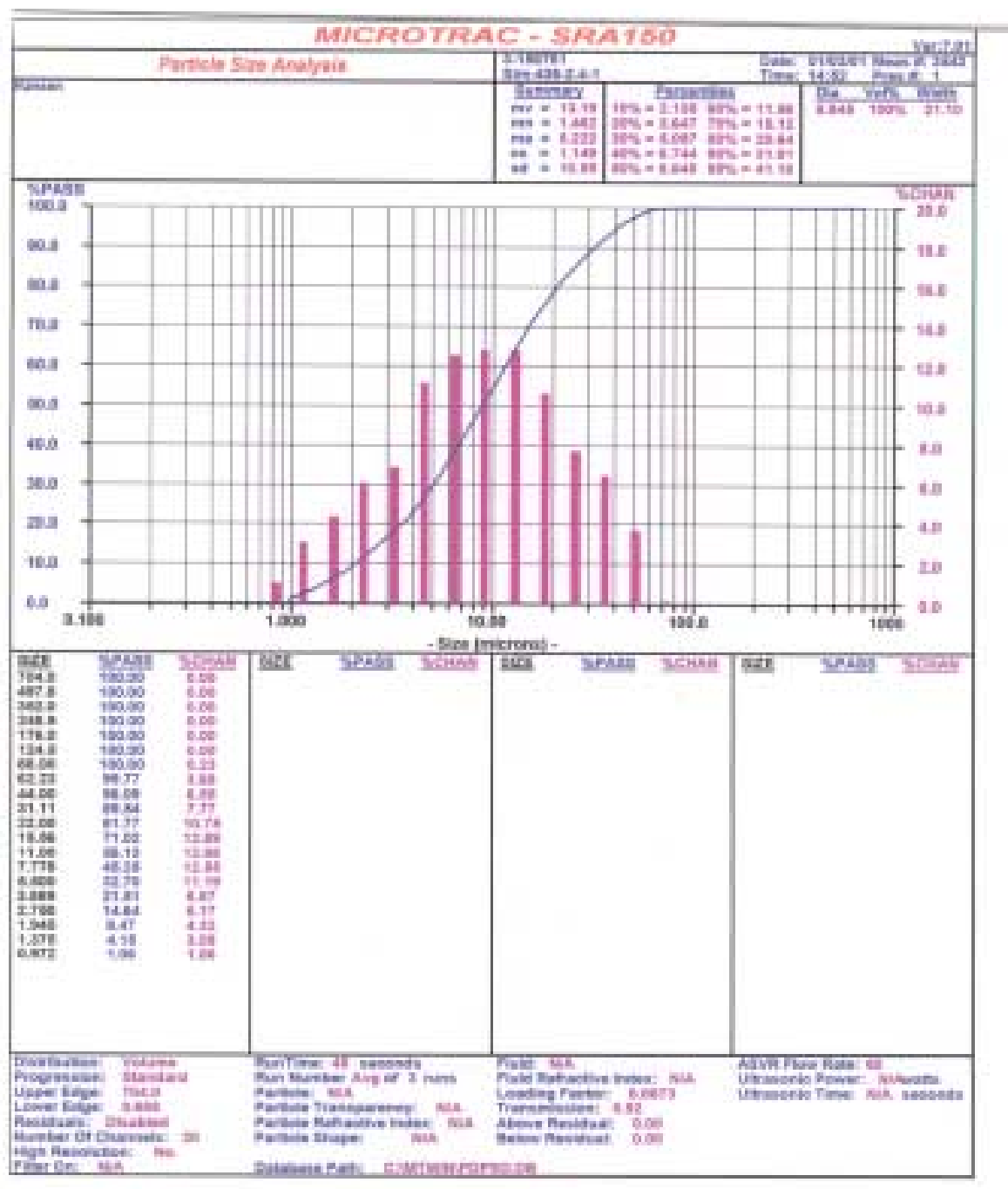


FIGURE A - 39 Particle Size Test No. 2.5, without Glass Formers

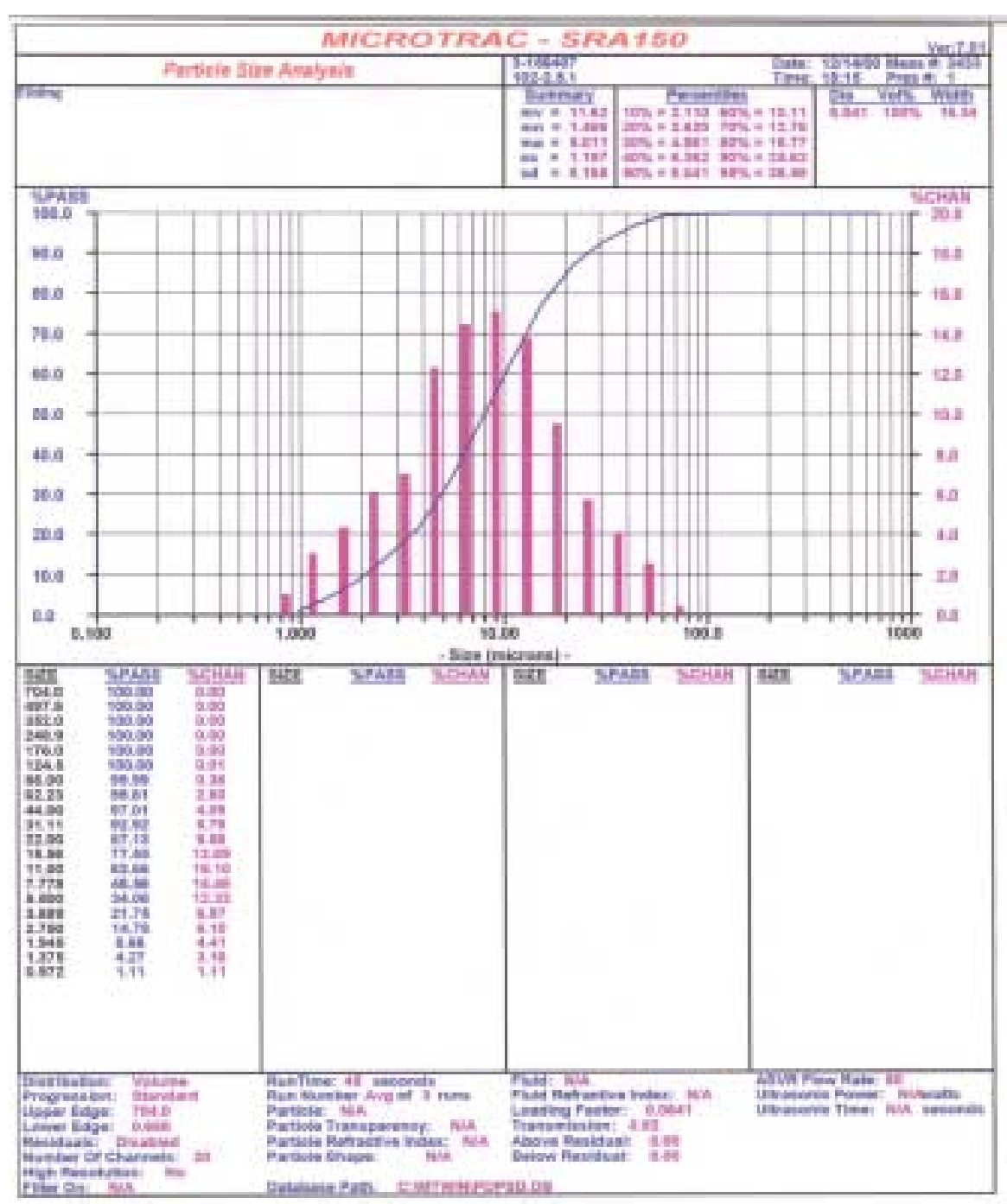

FIGURE A - 40 Particle Size Test No. 2.5, with Glass Formers
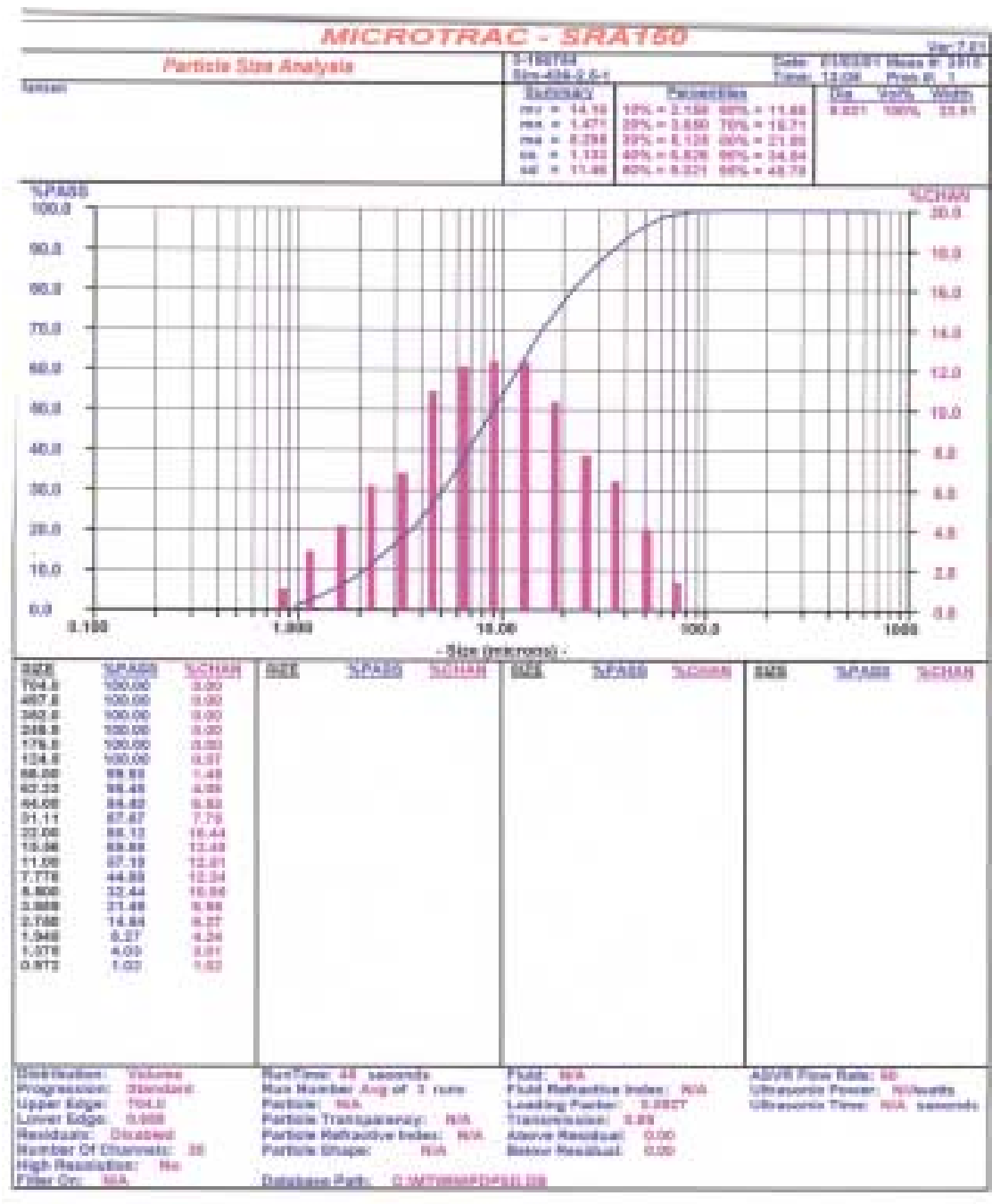
WSRC-TR-2001-00203, Rev. 0

SRT-RPP-2001-00051, Rev. 0 TRPT-24590-01-00001

FIGURE A - 41 Particle Size Test No. ADD-3, without Glass Formers

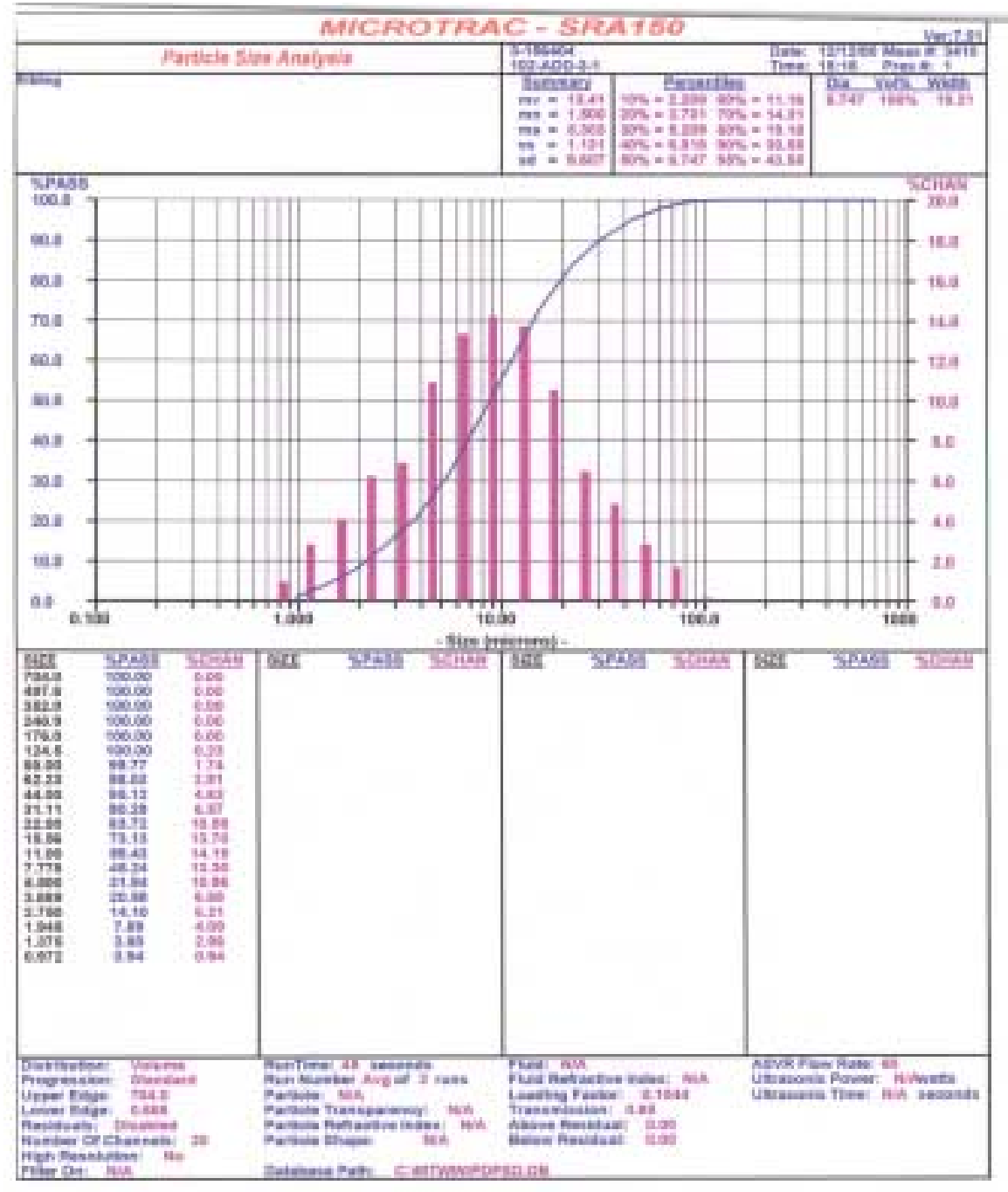

\section{FIGURE A - 42 Particle Size Test No. ADD-3 with Glass Formers}

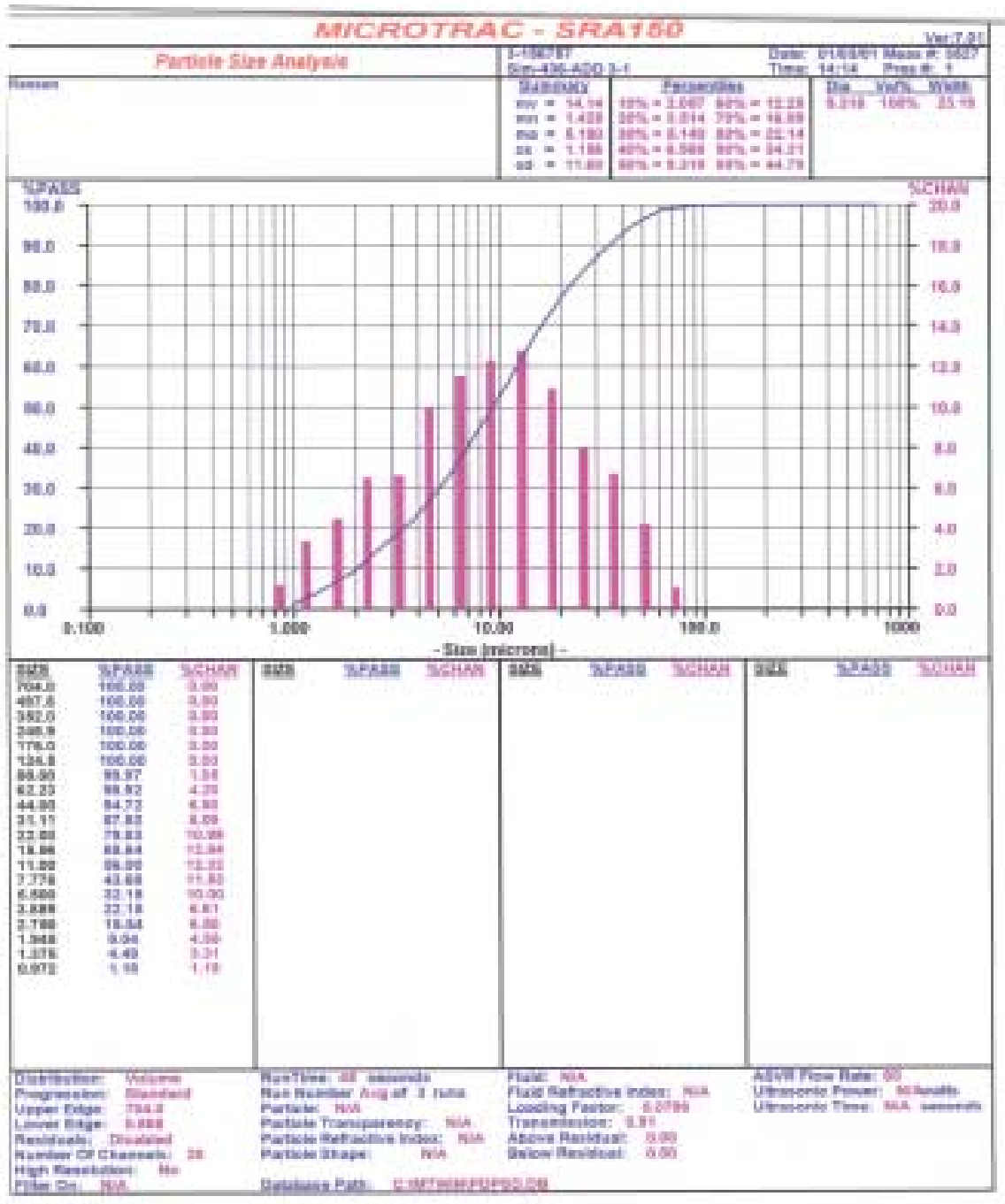


WSRC-TR-2001-00203, Rev. 0

FIGURE A - 43 Particle Size Test No. ADD-4, without Glass Formers

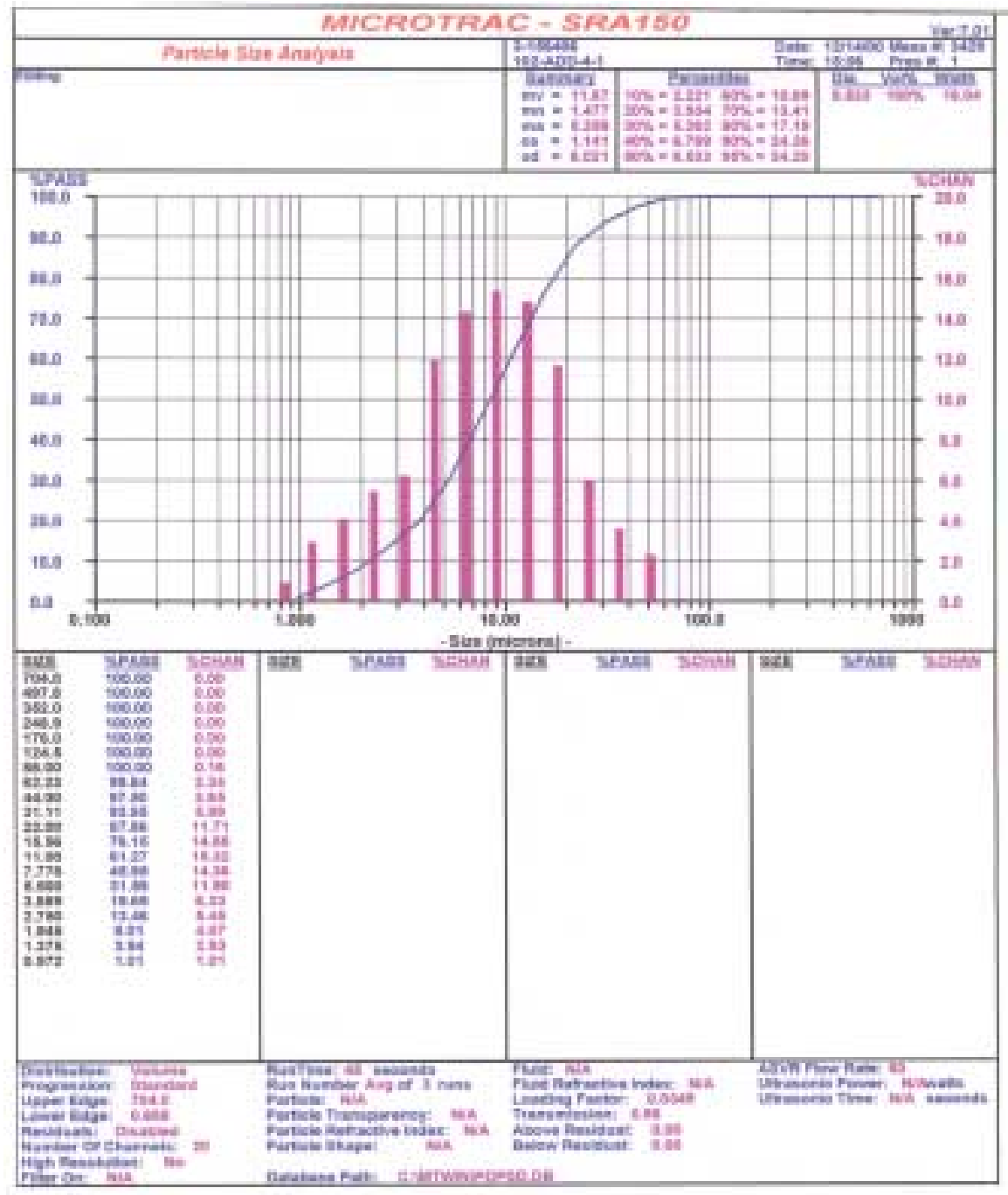

FIGURE A - 44 Particle Size Test No. ADD-4, with Glass Formers
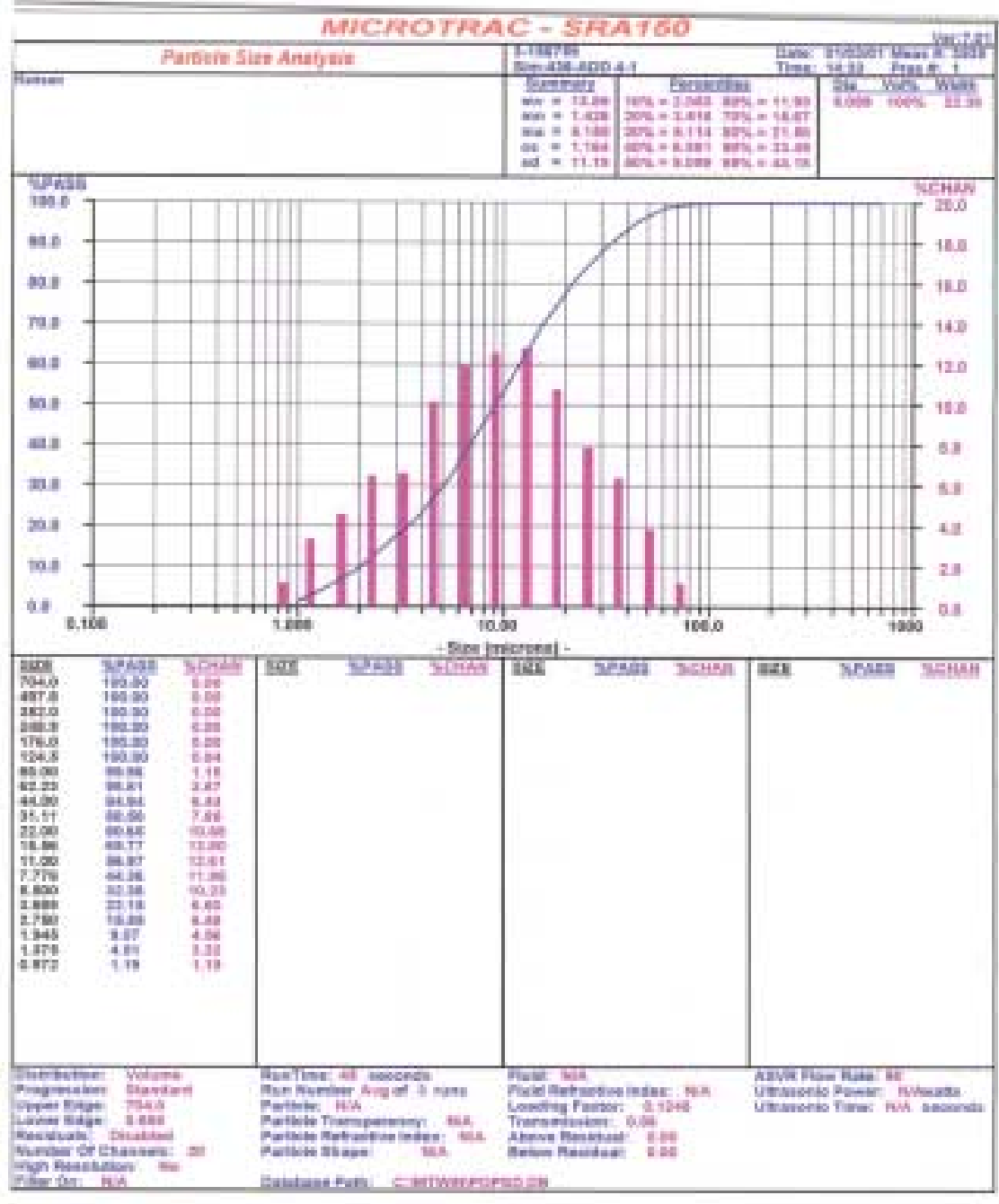
WSRC-TR-2001-00203, Rev. 0

SRT-RPP-2001-00051, Rev. 0

TRPT-24590-01-00001

\section{APPENDIX B: Simulant Preparation and Blending}

\section{Table of Appendix B Tables}

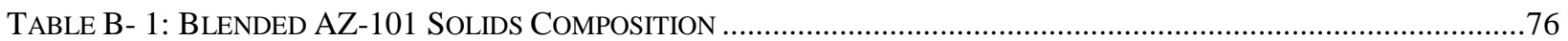

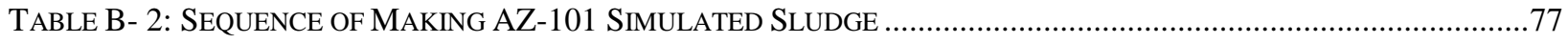

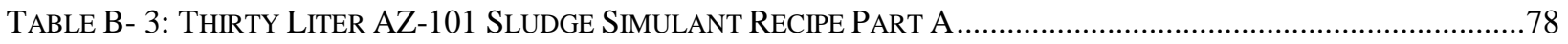

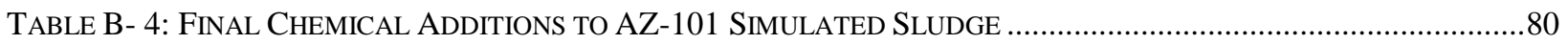

TABLE B- 5: AZ-101 SIMULATED SLUDGE INITIAL PHYSICAL PROPERTIES ...................................................80

TABLE B- 6: MEASURED COMPARED TO TARGET AZ-101 SLUDGE COMPOSITION WT. \% OXIDES ..........................81

TABLE B- 7: PARTICLE SIZE SHEARING RESULTS FOR SIMULATED AZ-101 SLUDGE......................................81

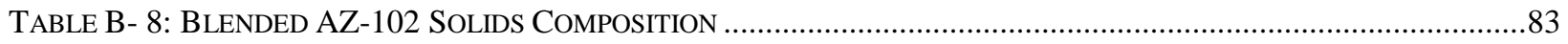

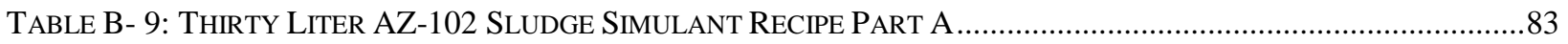

TABLE B- 10: THIRTY LITER AZ-102 SIMULATED SLUDGE RECIPE PART B FINAL CHEMICAL ADDITIONS TO AZ-102

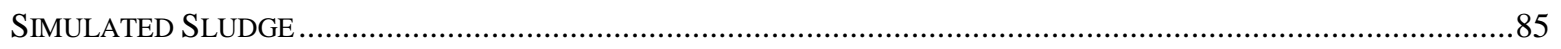

TABLE B- 11: AZ-102 SIMULATED SLUDGE INITIAL PHYSICAL PROPERTIES .........................................

TABLE B- 12: MEASURED COMPARED TO TARGET AZ-102 SLUDGE COMPOSITION WT. \% WASTE OXIDES .............86

TABLE B- 13: PARTICLE SIZE SHEARING RESULTS FOR AZ-102 SIMULATED SLUDGE .....................................86

TABLE B- 14: SEQUENCE OF MAKING AN-107 ENTRAINED SOLIDS SIMULANT.........................................

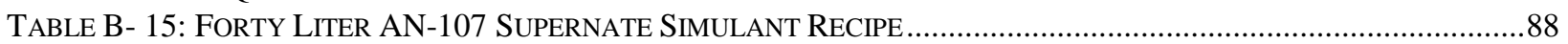

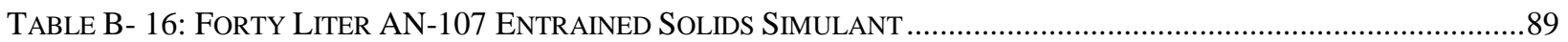

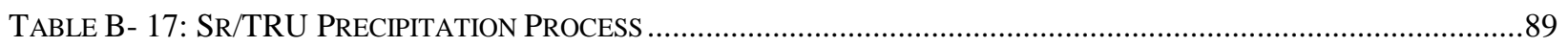

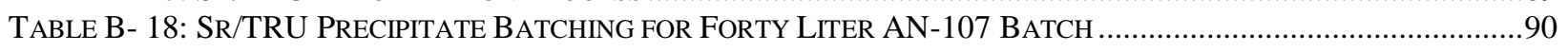

TABLE B- 19: INITIAL SR/TRU UNWASHED PRECIPITATE PHYSICAL PROPERTIES ........................................

TABLE B- 20: THIRTY LITER AN-107 SUPERNATE SIMULANT RECIPE (BATCH 2) ........................................

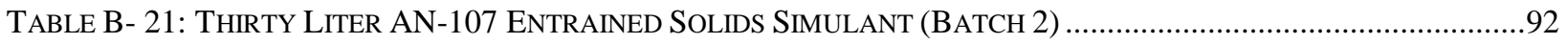

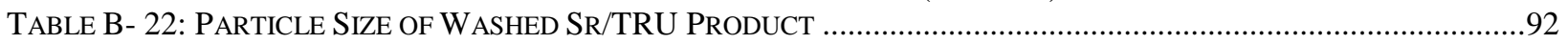

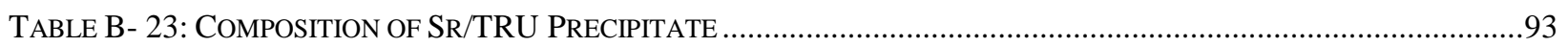

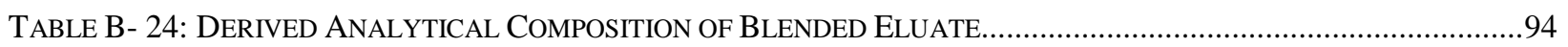

TABLE B- 25: BLENDED ELUATE RECIPE FOR TWO LITERS OF FEED ........................................................95

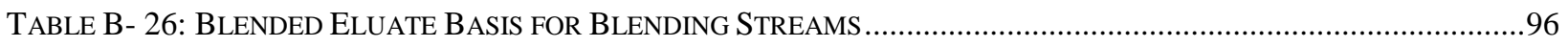

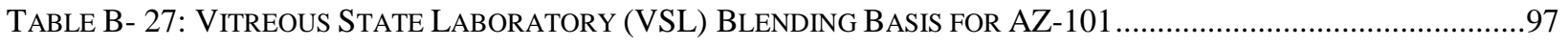

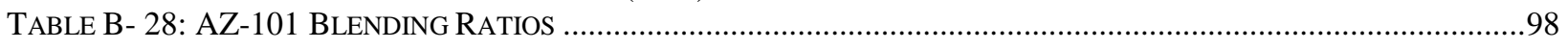

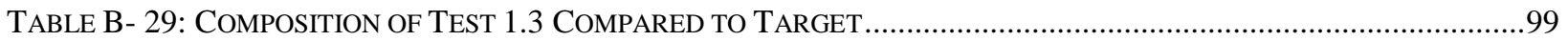

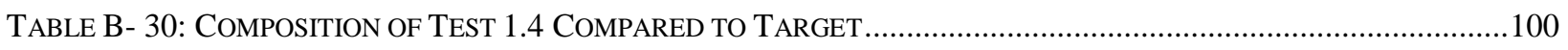

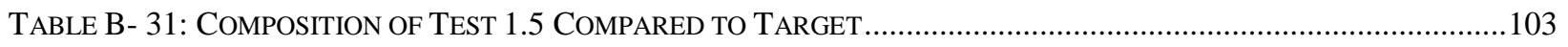

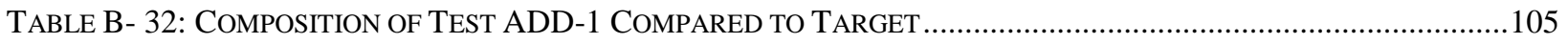

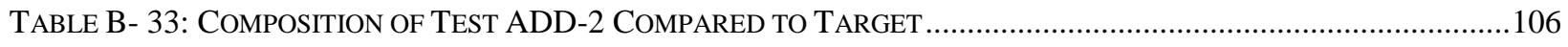

TABLE B- 34: VSL BLENDING RATIO FOR AZ-102 WASTE GLASS .......................................................107

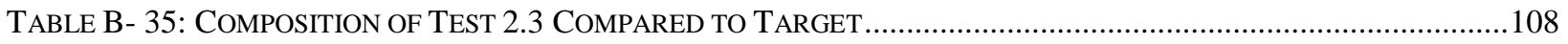

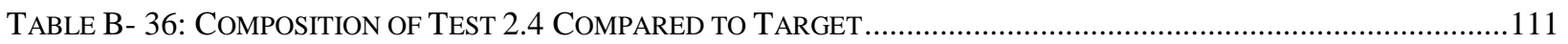

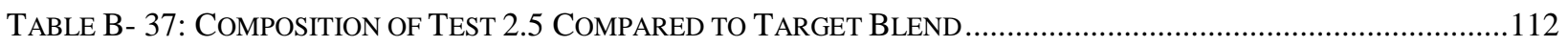

TABLE B- 38: COMPOSITION OF TEST 2.9 COMPARED TO TARGET BLEND ..............................................

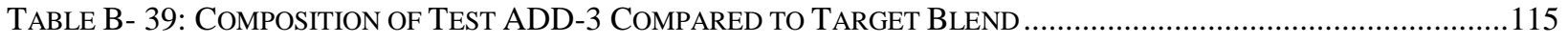

TABLE B- 40: COMPOSITION OF TEST ADD-4 COMPARED TO TARGET BLEND .............................................116

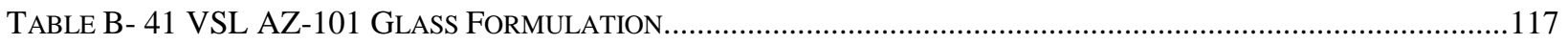

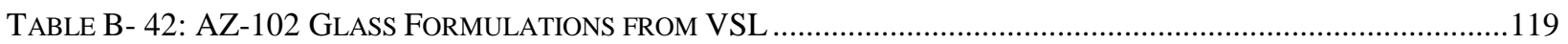

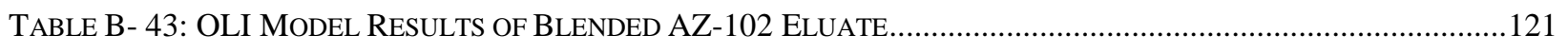


WSRC-TR-2001-00203, Rev. 0

SRT-RPP-2001-00051, Rev. 0 TRPT-24590-01-00001

Table of Appendix B Figures

FIGURE B - 1 WASHING OF PRECIPITATED AZ-101 SiMULATED SLUDGE SOLIDS .............................................79

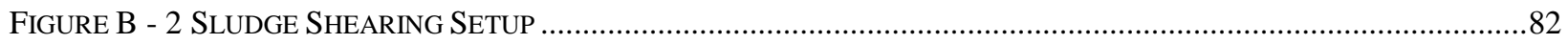

FIGURE B - 3 WASHING OF PRECIPITATED AZ-102 SLUDGE SIMULANT SOLIDS ................................................84

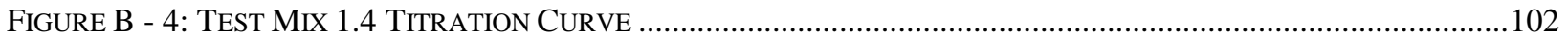

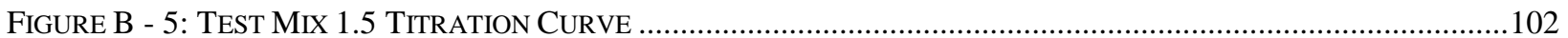

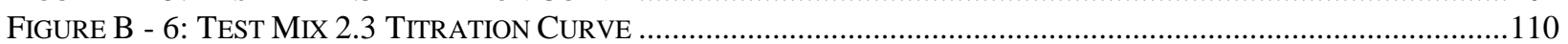

FIGURE B - 7: TEST MIXTURE 2.5 TITRATION CURVE ........................................................................110 
WSRC-TR-2001-00203, Rev. 0

SRT-RPP-2001-00051, Rev. 0

TRPT-24590-01-00001

\section{AZ-101 Sludge Simulant}

The sludge simulants used in this study were created by caustic precipitation of metal nitrate solutions. The precipitation procedure is designed to mimic the waste generation process, which has occurred within the Hanford waste tanks. The aspects of waste storage that cannot be duplicated are radiation exposure and thermal aging. The basis for the composition of the AZ101 sludge simulant was derived from the composition of two core samples from tank 241-AZ10124. The AZ-101 simulant composition represents AZ-101 sludge that has been washed, but not caustic leached to reduce the aluminum content. Table B-1 is the AZ-101 sludge composition.

Table B- 1: Blended AZ-101 Solids Composition

\begin{tabular}{|c|c|c|c|c|c|}
\hline \multicolumn{1}{c}{ Component } & $\mathbf{g} / \mathbf{L}$ & $\boldsymbol{\mu g} / \mathbf{g}$ of solids & \multicolumn{1}{c|}{ Component } & $\mathbf{g} / \mathbf{L}$ & $\boldsymbol{\mu g} / \mathbf{g}$ of solids \\
\hline Aluminum & 8.970 & 57907 & Nickel & 2.719 & 17552 \\
\hline Barium & 0.328 & 2114 & Potassium & 0.986 & 6365 \\
\hline Boron & 0.124 & 803 & Silver & 0.346 & 2235 \\
\hline Cadmium & 3.454 & 22295 & Sodium & 12.853 & 82976 \\
\hline Calcium & 1.400 & 9036 & Silicon & 2.182 & 14084 \\
\hline Cerium & 0.436 & 2817 & Strontium & 0.234 & 1508 \\
\hline Chromium & 0.347 & 2238 & Titanium & 0.042 & 274 \\
\hline Cobalt & 0.443 & 2860 & Zinc & 0.134 & 865 \\
\hline Copper & 0.152 & 979 & Zirconium & 14.772 & 95366 \\
\hline Iron & 44.150 & 285023 & TIC & 1.109 & 7161 \\
\hline Lanthanum & 1.784 & 11520 & Chloride & 0.039 & 255 \\
\hline Lead & 0.505 & 3258 & Fluoride & 0.215 & 1390 \\
\hline Magnesium & 0.249 & 1610 & Nitrate & 3.909 & 25238 \\
\hline Manganese & 1.027 & 6630 & Nitrite & 5.567 & 35942 \\
\hline Molybdenum & 0.022 & 144 & Phosphate & 0.260 & 1678 \\
\hline Neodymium & 1.192 & 7696 & Sulfate & 1.406 & 9078 \\
\hline
\end{tabular}

Table B-1 does not include any uranium since a non-radioactive simulant was required for this study. The required concentration for uranium would be 24810 micrograms/gram solids.

The AZ-101 sludge simulant was calculated to produce thirty liters of simulant or about 4600 grams of sludge solids. The AZ-101 simulated sludge was produced by the following sequence of reactions and mixing steps shown in Table B-2 based upon the sludge simulation method that has been previously described. 26

\footnotetext{
24 K. M. Hodgson, Tank Characterization Report for Double-Shell Tank 241-AZ-101, WHC-SD-WM-ER-410, Rev 0, Westinghouse Hanford Company, Richland, WA 99352 (July 26. 1995).

25 E. V. Morrey, J. M. Tingey, M. L. Elliott, Comparison of Simulants to Actual Neutralized Current Acid Waste: Process and Product Testing of Three NCAW Core Samples From Tanks 101-AZ and 102-AZ, PNNL-11025, UC-2030, Pacific Northwest National Laboratory, Richland, WA 99352 (October 1996).

${ }^{26}$ R. E. Eibling and C. Nash, Hanford Waste Simulants Created to Support the Research and Development on the River Protection Project - Waste Treatment Plant, WSRC-TR-2000-00338, SRT-RPP-2000-00017, Westinghouse Savannah River Company, Aiken, SC 29808 (September 2000).
} 
Table B- 2: Sequence of Making AZ-101 Simulated Sludge

\begin{tabular}{|c|l|}
\hline Sequence & Reaction \\
\hline A & $\begin{array}{l}\text { The generation of hydrated manganese dioxide by reacting permanganate ion and } \\
\text { manganese (II) ion. }\end{array}$ \\
\hline B & Addition of transition metals and alkaline earth metals as metal nitrates or chlorides. \\
\hline C & $\begin{array}{l}\text { Precipitation of the metal ions by addition of } 8 \text { molar sodium hydroxide solution until the } \\
\text { pH is greater than } 10 .\end{array}$ \\
\hline D & $\begin{array}{l}\text { Addition of } 12 \text { liters of } 0.6 \text { molar sodium carbonate solution to enable the conversion of } \\
\text { some of the hydroxides to the less-soluble carbonates, such as the conversion of strontium } \\
\text { hydroxide to strontium carbonate. }\end{array}$ \\
\hline E & $\begin{array}{l}\text { Wash the sludge with inhibited water }\left(0.01 \text { molar NaOH and } 0.01 \text { molar } \mathrm{NaNO}_{2}\right) \text { to } \\
\text { reduce the nitrate concentration to less than } 1000 \mathrm{mg} / \mathrm{L} .\end{array}$ \\
\hline F & Add hydroxide-reactive insoluble species of known particle size. \\
\hline G & Add soluble salts to the desired final concentrations. \\
\hline
\end{tabular}

The precipitation and washing was started in a 50 liter polypropylene carboy with its top removed to allow the positioning of an agitator for mixing the sludge. The precipitation was conducted at ambient lab temperatures, 293-298 K, with no provision for controlling the solution temperature. Two impellers on one shaft were used to provide the mixing. The lower impeller, located near the bottom of the vessel, was a 3 -inch diameter, $1 / 2$ inch wide 6-blade Rushton impeller. The top impeller, located approximately 10 inches above the bottom impeller was as 3inch diameter, $1 / 2$ inch wide, 4 -blade $45^{\circ}$ pitched impeller. The speed of the shaft ranged between 500 to $1500 \mathrm{rpm}$ to provide adequate mixing in preparing the sludge. Table B-3 lists the reagents used to complete sequence steps $\mathrm{A}$ and $\mathrm{B}$ of the sludge preparation procedure. 
WSRC-TR-2001-00203, Rev. 0

Table B- 3: Thirty Liter AZ-101 Sludge Simulant Recipe Part A

\begin{tabular}{|c|l|l|c|}
\hline Sequence & Compound & $\mathrm{H}_{2} \mathrm{O}$ & Mass, grams \\
\hline A & Water & $\mathrm{KMnO}$ & 15000.04 \\
\hline A & Potassium Permanganate & $50 \mathrm{Wt}_{4}$ & 35.45 \\
\hline A & Managanous Nitrate Solution & $\mathrm{Fe}\left(\mathrm{NO}_{3}\right)_{3} \bullet 9 \mathrm{H}_{2} \mathrm{O}$ & 120.43 \\
\hline B & Ferric Nitrate & $\mathrm{Ni}\left(\mathrm{NO}_{3}\right)_{2} \bullet 6 \mathrm{H}_{2} \mathrm{O}$ & 9581.5 \\
\hline B & Nickel Nitrate & $\mathrm{NiCl}_{2} \bullet 6 \mathrm{H}_{2} \mathrm{O}$ & 263.91 \\
\hline B & Nickelous Chloride & $\mathrm{ZrO}\left(\mathrm{NO}_{3}\right)_{2} \bullet \mathrm{xH}_{2} \mathrm{O} \times \sim 6$ & 114.66 \\
\hline B & Zirconyl Nitrate & $\mathrm{Ce}\left(\mathrm{NO}_{3}\right)_{3} \bullet 6 \mathrm{H}_{2} \mathrm{O}$ & 1648.5 \\
\hline B & Cerium Nitrate & $\mathrm{La}\left(\mathrm{NO}_{3}\right)_{3} \bullet 6 \mathrm{H}_{2} \mathrm{O}$ & 40.57 \\
\hline B & Lanthanum Nitrate & $\mathrm{Nd}\left(\mathrm{NO}_{3}\right)_{3} \bullet 6 \mathrm{H}_{2} \mathrm{O}$ & 166.87 \\
\hline B & Neodymium Nitrate & $\mathrm{Ba}\left(\mathrm{NO}_{3}\right)_{2}$ & 108.68 \\
\hline B & Barium Nitrate & $\mathrm{Ca}\left(\mathrm{NO}_{3}\right)_{2} \bullet 4 \mathrm{H}_{2} \mathrm{O}$ & 18.70 \\
\hline B & Calcium Nitrate & $\mathrm{Cd}\left(\mathrm{NO}_{3}\right)_{2} \bullet 4 \mathrm{H}_{2} \mathrm{O}$ & 247.42 \\
\hline B & Cadmium Nitrate & $\mathrm{Cr}\left(\mathrm{NO}_{3}\right)_{3} \bullet 9 \mathrm{H}_{2} \mathrm{O}$ & 284.31 \\
\hline B & Chromium Nitrate & $\mathrm{Co}\left(\mathrm{NO}_{3}\right)_{2} \bullet 6 \mathrm{H}_{2} \mathrm{O}$ & 80.04 \\
\hline B & Cobalt Nitrate & $\mathrm{Cu}\left(\mathrm{NO}_{3}\right)_{2} \bullet 6 \mathrm{H}_{2} \mathrm{O}$ & 65.62 \\
\hline B & Copper Nitrate & $\mathrm{Dy}\left(\mathrm{NO}_{3}\right)_{3} \bullet 5 \mathrm{H}_{2} \mathrm{O}$ & 17.30 \\
\hline B & Dysprosium Nitrate & $\mathrm{Mg}\left(\mathrm{NO}_{3}\right)_{2} \bullet 6 \mathrm{H}_{2} \mathrm{O}$ & 1.925 \\
\hline B & Magnesium Nitrate & $\mathrm{Pb}\left(\mathrm{NO}_{3}\right)_{2}$ & 24.94 \\
\hline B & Lead Nitrate & $\mathrm{Rh}\left(\mathrm{NO}_{3}\right)_{3}, 4.933 \mathrm{wt} \% \mathrm{Rh}$ & 93.59 \\
\hline B & Rhodium Nitrate Solution & $\mathrm{RuCl}{ }_{3}, 41.74 \mathrm{wt} \% \mathrm{Ru}$ & 18.47 \\
\hline B & Ruthenium Trichloride & $\mathrm{Sr}\left(\mathrm{NO}_{3}\right)_{2}$ & 16.926 \\
\hline B & Strontium Nitrate & $\mathrm{Zn}\left(\mathrm{NO}_{3}\right)_{2} \bullet 6 \mathrm{H}_{2} \mathrm{O}$ & 18.31 \\
\hline B & Zinc Nitrate & $\mathrm{AgNO}$ & \\
\hline B & Silver Nitrate & & 16.357 \\
\hline
\end{tabular}

The $\mathrm{pH}$ of the simulant was 0.28 after the metal addition listed as sequence B in Table B-2 was completed. The metals were precipitated with 8 molar sodium hydroxide by adding the sodium hydroxide solution at $5-10 \mathrm{~mL} / \mathrm{min}$ while agitating at $500-800 \mathrm{rpm}$ until the slurry $\mathrm{pH}$ was greater than ten (Table B-2, sequence $\mathrm{C}$ ). The $\mathrm{pH}$ of the solution was monitored during the addition of sodium hydroxide solution. Mixing was difficult after the $\mathrm{pH}$ had risen above four and fouling of the $\mathrm{pH}$ probe required frequent cleaning to support the $\mathrm{pH}$ measurement. After reaching a $\mathrm{pH}$ of 10 , twelve liters of 0.6 molar sodium carbonate solution was added (Table B- 2 , sequence D) and the sludge slurry mixed for several hours. The slurry was then allowed to settle for 48 hours. The settled volume of the AZ-101 sludge simulant was about forty liters.

Since batch washing with gravity settling was planned for reducing the nitrate concentration, the settled sludge was blended and then split into two batches. The first wash for each batch was with deionized water. Subsequent washes were with inhibited water, 0.01 molar in $\mathrm{NaOH}$ and 0.01 molar in $\mathrm{NaNO}_{2}$. Samples of the decanted supernate were analyzed for anions to determine when the washing endpoint was reached. Figure B -1 shows the nitrate, chloride and nitrite concentrations during each stage of washing. 
Figure B - 1 Washing of Precipitated AZ-101 Simulated Sludge Solids

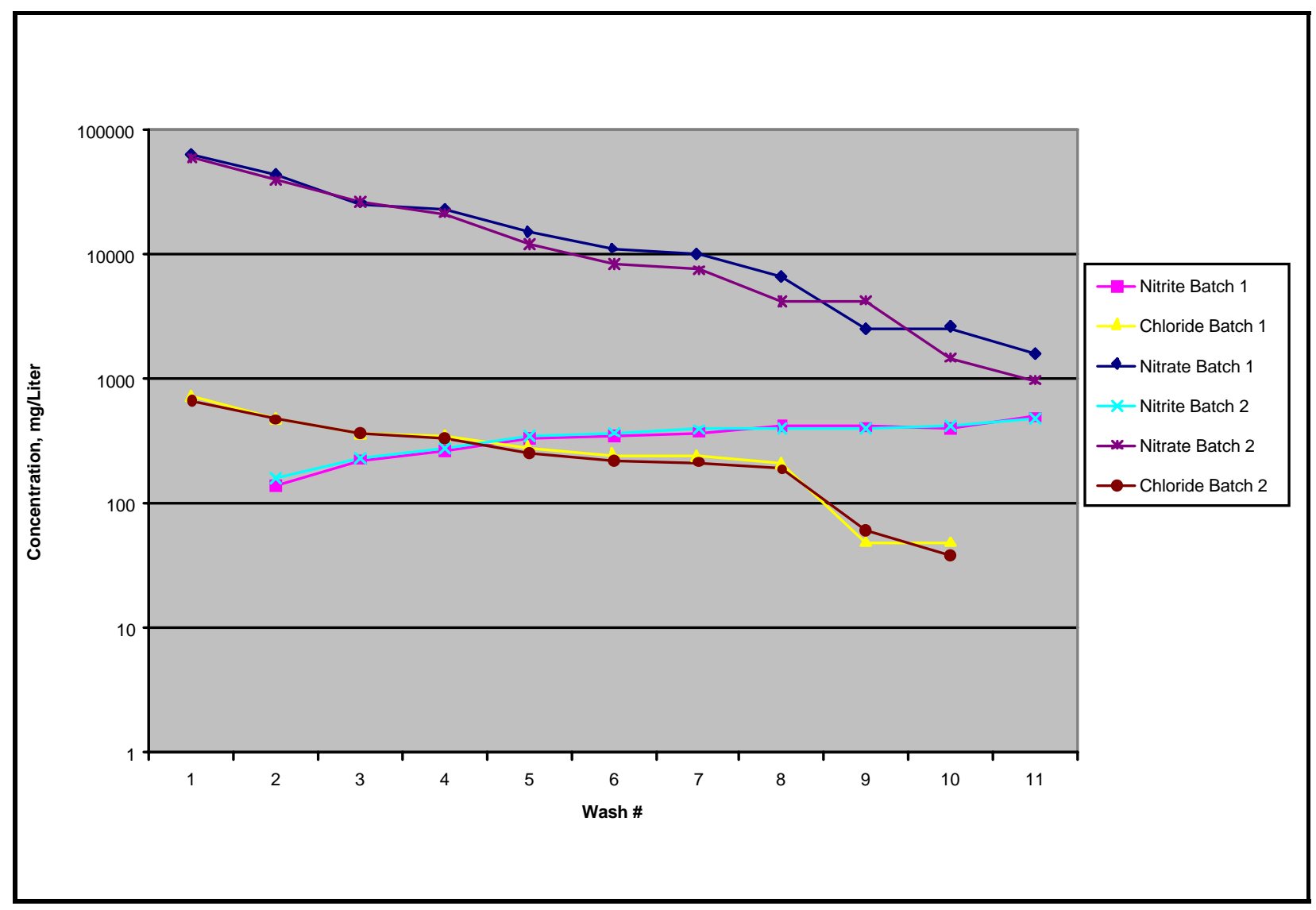

The decanted washes had virtually no color indicating that the transition metals were remaining insoluble during the series of washes. The large number of washes was dictated by the limited wash volume that could be obtained at each step, due to the limited free supernate that could be decanted. The settling time for each wash step was generally 18-48 hours. The washed solids from each batch were blended together after the final wash to allow the remaining sequence of additions to occur on a single batch.

The final addition of chemicals to the simulated sludge consisted of insoluble solids, which could react with the hydroxide used to precipitate the transition metals, and the soluble salts. Table B$\bigoplus$ lists the sequence and final chemical additions necessary to produce thirty liters of simulated AZ-101 sludge. 
WSRC-TR-2001-00203, Rev. 0

Table B- 4: Final Chemical Additions to AZ-101 Simulated Sludge

\begin{tabular}{|c|c|c|c|}
\hline Sequence & Compound & Formula & Mass, grams \\
\hline $\mathrm{F}$ & Titanium Dioxide & $\mathrm{TiO}_{2},<5$ micron & 2.127 \\
\hline $\mathrm{F}$ & Silica & $\mathrm{SiO}_{2},<5$ microns & 140.02 \\
\hline $\mathrm{F}$ & Aluminum Oxide & $\mathrm{Al}_{2} \mathrm{O}_{3},<10$ microns & 508.43 \\
\hline $\mathrm{G}$ & Sodium Perrhenate & $\mathrm{NaReO}_{4}$ & 1.080 \\
\hline $\mathrm{G}$ & Potassium Nitrate & $\mathrm{KNO}_{3}$ & 75.08 \\
\hline $\mathrm{G}$ & Potassium Molybdate & $\mathrm{K}_{2} \mathrm{MoO}_{4}$ & 1.67 \\
\hline $\mathrm{G}$ & Boric Acid & $\mathrm{H}_{3} \mathrm{BO}_{3}$ & 21.35 \\
\hline $\mathrm{G}$ & Sodium Chloride & $\mathrm{NaCl}$ & 1.95 \\
\hline $\mathrm{G}$ & Sodium Fluoride & $\mathrm{NaF}$ & 14.28 \\
\hline $\mathrm{G}$ & Sodium Sulfate & $\mathrm{Na}_{2} \mathrm{SO}_{4}$ & 62.38 \\
\hline $\mathrm{G}$ & Sodium Phosphate & $\mathrm{Na}_{3} \mathrm{PO}_{4} \bullet 12 \mathrm{H}_{2} \mathrm{O}$ & 595.92 \\
\hline G & Sodium Nitrate & $\mathrm{NaNO}_{3}$ & 119.64 \\
\hline $\mathrm{G}$ & Sodium Nitrite & $\mathrm{NaNO}_{2}$ & 250.50 \\
\hline
\end{tabular}

After the final chemical addition, the sludge was mixed and sampled for chemical analysis, particle size and solids loading. The final $\mathrm{pH}$ of the slurry was 10.39 , which is reasonable for a slurry that initially was 0.01 molar in $\mathrm{NaOH}$ and has not been protected from absorption of carbon dioxide from the air. Absorption of carbon dioxide leads to a reduction in the free hydroxide concentration and the production of carbonate ion by the following reaction (9).

$$
\mathrm{CO}_{2}+2 \mathrm{OH}^{-} \longrightarrow \mathrm{CO}_{3}^{-2}+\mathrm{H}_{2} \mathrm{O}
$$

Table B-5 ists the measured slurry physical properties.

Table B- 5: AZ-101 Simulated Sludge Initial Physical Properties

\begin{tabular}{|l|r||}
\hline Weight \% Total Solids & 11.77 \\
\hline Weight \% Soluble Solids & 1.45 \\
\hline Weight \% Insoluble Solids & 10.31 \\
\hline Density at $295 \mathrm{~K}$ in $\mathrm{kg} / \mathrm{m}^{3}$ & 1077 \\
\hline \hline
\end{tabular}

The measured composition of the AZ-101 simulated sludge expressed in terms of weight $\%$ waste oxides is shown in Table B- 6 compared to the target composition. The only species which are significantly below the target concentration are the alkaline earth elements $(\mathrm{Mg}, \mathrm{Ca}$, and $\mathrm{Sr}$ ) which were probably removed by the washing steps due to the limited solubility of the carbonate species expected in the sludge. 
WSRC-TR-2001-00203, Rev. 0

Table B- 6: Measured Compared to Target AZ-101 Sludge Composition Wt. \% Oxides

\begin{tabular}{|c|c|c|c|c|c|}
\hline \multirow{2}{*}{$\begin{array}{l}\text { Waste } \\
\text { Oxide }\end{array}$} & \multicolumn{2}{|c|}{$\begin{array}{l}\text { Wt. \% waste oxide } \\
\text { Composition }\end{array}$} & \multirow{2}{*}{$\begin{array}{l}\text { Waste } \\
\text { Oxide }\end{array}$} & \multicolumn{2}{|c|}{$\begin{array}{l}\text { Wt. \% waste oxide } \\
\text { Composition }\end{array}$} \\
\hline & Measured & Target & & Measured & Target \\
\hline $\mathrm{Ag}_{2} \mathrm{O}$ & 0.18 & 0.26 & $\mathrm{MnO}$ & 0.96 & 0.91 \\
\hline $\mathrm{Al}_{2} \mathrm{O}_{3}$ & 13.60 & 11.63 & $\mathrm{MoO}_{3}$ & 0.02 & 0.02 \\
\hline $\mathrm{BaO}$ & 0.22 & 0.25 & $\mathrm{Na}_{2} \mathrm{O}$ & 11.06 & 11.89 \\
\hline $\mathrm{CaO}$ & 0.71 & 1.34 & $\mathrm{Nd}_{2} \mathrm{O}_{3}$ & 0.92 & 0.95 \\
\hline $\mathrm{CdO}$ & 2.64 & 2.71 & $\mathrm{NiO}$ & 2.42 & 2.37 \\
\hline $\mathrm{CeO}_{2}$ & 0.26 & 0.37 & $\mathrm{P}_{2} \mathrm{O}_{5}$ & 2.86 & 2.54 \\
\hline $\mathrm{CoO}$ & 0.40 & 0.39 & $\mathrm{PbO}$ & 0.37 & 0.37 \\
\hline $\mathrm{Cr}_{2} \mathrm{O}_{3}$ & 0.36 & 0.35 & $\mathrm{SiO}_{2}$ & 3.37 & 3.20 \\
\hline $\mathrm{CuO}$ & 0.13 & 0.13 & $\mathrm{SrO}$ & 0.10 & 0.19 \\
\hline $\mathrm{Fe}_{2} \mathrm{O}_{3}$ & 44.03 & 43.31 & $\mathrm{TiO}_{2}$ & $<0.06$ & 0.05 \\
\hline $\mathrm{K}_{2} \mathrm{O}$ & 0.99 & 1.23 & $\mathrm{ZnO}$ & 0.13 & 0.11 \\
\hline $\mathrm{La}_{2} \mathrm{O}_{3}$ & 1.39 & 1.44 & $\mathrm{ZrO}_{2}$ & 12.77 & 13.69 \\
\hline $\mathrm{MgO}$ & 0.09 & 0.28 & & & \\
\hline
\end{tabular}

The processing of the actual Envelope D waste by the WTP will involve the transfer of the sludge by pumps from the tank farm to feed tanks. The sludge will then be washed with dilute caustic to remove soluble salts and reduce the sodium concentration. The separation of the wash liquid and control of solids loading in the product slurry will be accomplished by crossflow filtration. Since the actual Envelope D waste will experience substantial shearing during the crossflow filtration, the washed, simulated AZ-101 sludge was sheared by pumping the simulant through a pump typically used for a small crossflow filter. The amount of applied spearing used in this task was based on the Cells Filter Unit (CUF) operations performed at SRTC specifically the shearing applied by the CUF pump. Based on the CUF operations approximately 20 minutes to process $1 \mathrm{~L}$ of Envelope $\mathrm{C}$ (with precipitated Sr/TRU). The CUF pump is a modified progressive cavity pump (high shear - due to the tight tolerances between the rotor and sleeve), which was operated at 30 psig to provide a recirculation flowrate of approximately $5 \mathrm{gpm}$. Thus, for the 40L AZ-101 batch, 13.3 hours of recirculation using the CUF pump was used to apply the appropriate amount of shearing. The slurry was removed from the bottom of the mixing vessel and returned just below the surface of the slurry. An agitator, with a single 3 -inch diameter, $1 / 2$ inch wide 6-blade Rushton impeller, located near the bottom, was used to assist the mixing in the vessel. The agitator applies much less shear than the CUF pump and its contribution was neglected in the shearing process. The agitator was operated at $550 \mathrm{rpm}$. A typical layout is shown in Figure B - 2. Samples of the simulated sludge before and after shearing were analyzed for particle size and the results are shown in Table B- 7 .

Table B- 7: Particle Size Shearing Results for Simulated AZ-101 Sludge

\begin{tabular}{|l|c|c|}
\hline & Before Shearing & After Shearing \\
\hline Mean Particle Size by Volume & $\mathbf{1 4 . 1 5}$ microns & 8.17 microns \\
Mean Particle Size by Number & 2.11 microns & 1.46 microns \\
Largest Particles & 125 micron & 62 micron \\
\hline
\end{tabular}

27 Charles Nash, "Simulant Shearing Basis", email, 6/21/00 
WSRC-TR-2001-00203, Rev. 0

Figure B - 2 Sludge Shearing Setup

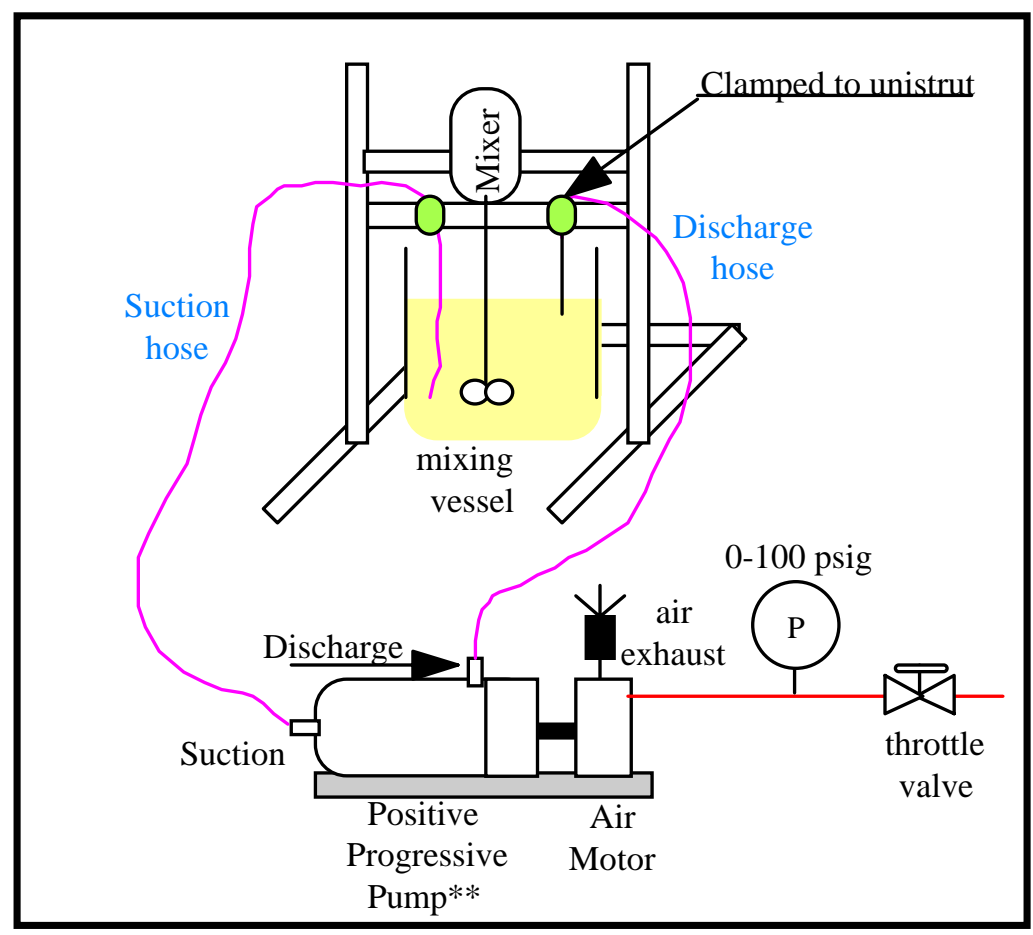

Different solids concentrations of AZ-101 simulated sludge were obtained by centrifuging at $42500 \mathrm{~m} / \mathrm{s}^{2}$ and adding back the amount of supernate to achieve the desired solids loading. The residual supernate was retained for use in diluting to lower solids loadings. The slurries prepared are listed in Table 4

\section{AZ-102 Sludge Simulant}

The AZ-102 sludge simulant was prepared in the same manner as the AZ-101 sludge simulant already described. The sludge composition listed in Table B- 8 represents pretreated (washed but not caustic leached) sludge. 28 The sequence of steps in preparing the simulated sludge was the same as listed in Table B-2. The precipitation and washing was started in a 50 liter polypropylene carboy with its top removed to allow the positioning of an agitator for mixing the sludge. The precipitation was conducted at ambient lab temperatures, 293-298 K, with no provision for controlling the solution temperature. Two impellers on one shaft were used to provide the mixing. The lower impeller, located near the bottom of the vessel, was a 3-inch diameter, $1 / 2$ inch wide 6 -blade Rushton impeller. The top impeller, located approximately 10 inches above the bottom impeller was as 3 -inch diameter, $1 / 2$ inch wide, 4 -blade $45^{\circ}$ pitched impeller. The speed of the shaft ranged between 500 to $1500 \mathrm{rpm}$ to provide adequate mixing in preparing the sludge. The simulated sludge was prepared in a thirty liter batch, and the amounts used for steps A and B are shown in Table B-9.

\footnotetext{
${ }^{28}$ K. P. Brooks, P. R. Bredt, S. K. Cooley, G. R. Golcar, L. K. Jagoda, K. G. Rappe, M. W. Urie, Characterization, Washing, Leaching and Filtration of AZ-102 Solids, PNWD-3045, BNFL-RPT-038 Rev. 0, Pacific Northwest National Laboratory, Richland, WA 99352 (August 2000).
} 
Table B- 8: Blended AZ-102 Solids Composition

\begin{tabular}{|c|c|c|c|c|c|}
\hline Component & $\mathrm{g} / \mathrm{L}$ & $\mu \mathrm{g} / \mathrm{g}$ of solids & Component $\mathbf{t}$ & $\mathrm{g} / \mathrm{L}$ & $\mu \mathrm{g} / \mathrm{g}$ of solids \\
\hline Aluminum & 11.43 & 107000 & Nickel & 1.729 & 16190 \\
\hline Barium & 0.101 & 944 & Silver & 0.050 & 464 \\
\hline Boron & 0.024 & 228 & Sodium & 8.022 & 75100 \\
\hline Cadmium & 3.431 & 32120 & Silicon & 0.758 & 7100 \\
\hline Calcium & 0.108 & 1007 & Strontium & 0.000 & 4 \\
\hline Cerium & 0.166 & 1550 & Titanium & 0.015 & 145 \\
\hline Chromium & 0.169 & 1582 & Zinc & 0.098 & 921 \\
\hline Cobalt & 0.013 & 118 & Zirconium & 3.488 & 32650 \\
\hline Copper & 0.001 & 5 & TIC & 0.174 & 1625 \\
\hline Iron & 23.560 & 220560 & Chloride & 0.139 & 1300 \\
\hline Lanthanum & 0.758 & 7094 & Fluoride & 0.032 & 300 \\
\hline Lead & 0.007 & 62 & Nitrate & 0.892 & 8350 \\
\hline Magnesium & 0.208 & 1950 & Nitrite & 0.187 & 1750 \\
\hline Manganese & 0.574 & 5369 & Phosphate & 0.096 & 897 \\
\hline Neodymium & 0.025 & 233 & Sulfate & 0.128 & 1200 \\
\hline
\end{tabular}

Table B- 9: Thirty Liter AZ-102 Sludge Simulant Recipe Part A

\begin{tabular}{|c|l|l|c|}
\hline Sequence & Compound & Formula & Mass, grams \\
\hline A & Water & $\mathrm{H}_{2} \mathrm{O}$ & 15000.2 \\
\hline A & Potassium Permanganate & $\mathrm{KMnO}$ & 19.802 \\
\hline A & Managanous Nitrate Solution & $50 \mathrm{Wt}_{4}$ & 67.273 \\
\hline B & Ferric Nitrate & $\mathrm{Fe}\left(\mathrm{NO}_{3}\right)_{2} \bullet 9 \mathrm{H}_{2} \mathrm{O}$ & 5113.1 \\
\hline B & Nickel Nitrate & $\mathrm{Ni}\left(\mathrm{NO}_{3}\right)_{2} \bullet 6 \mathrm{H}_{2} \mathrm{O}$ & 257.07 \\
\hline B & Zirconyl Nitrate & $\mathrm{ZrO}\left(\mathrm{NO}_{3}\right)_{2} \bullet \mathrm{xH}_{2} \mathrm{O} \times \sim 6$ & 389.2 \\
\hline B & Cerium Nitrate & $\mathrm{Ce}\left(\mathrm{NO}_{3}\right)_{3} \bullet 6 \mathrm{H}_{2} \mathrm{O}$ & 15.39 \\
\hline B & Lanthanum Nitrate & $\mathrm{La}\left(\mathrm{NO}_{3}\right)_{3} \bullet 6 \mathrm{H}_{2} \mathrm{O}$ & 70.87 \\
\hline B & Neodymium Nitrate & $\mathrm{Nd}\left(\mathrm{NO}_{3}\right)_{3} \bullet 6 \mathrm{H}_{2} \mathrm{O}$ & 2.28 \\
\hline B & Barium Nitrate & $\mathrm{Ba}\left(\mathrm{NO}_{3}\right)_{2}$ & 5.761 \\
\hline B & Calcium Nitrate & $\mathrm{Ca}\left(\mathrm{NO}_{3}\right)_{2} \bullet 4 \mathrm{H}_{2} \mathrm{O}$ & 19.01 \\
\hline B & Cadmium Nitrate & $\mathrm{Cd}\left(\mathrm{NO}_{3}\right)_{2} \bullet 4 \mathrm{H}_{2} \mathrm{O}$ & 282.48 \\
\hline B & Chromium Nitrate & $\mathrm{Cr}\left(\mathrm{NO}_{3}\right)_{3} \bullet 9 \mathrm{H}_{2} \mathrm{O}$ & 39.03 \\
\hline B & Cobalt Nitrate & $\mathrm{Co}\left(\mathrm{NO}_{3}\right)_{2} \bullet 6 \mathrm{H}_{2} \mathrm{O}$ & 1.87 \\
\hline B & Copper Nitrate & $\mathrm{Cu}\left(\mathrm{NO}_{3}\right)_{2} \bullet 6 \mathrm{H}_{2} \mathrm{O}$ & 0.066 \\
\hline B & Magnesium Nitrate & $\mathrm{Mg}\left(\mathrm{NO}_{3}\right)_{2} \bullet 6 \mathrm{H}_{2} \mathrm{O}$ & 65.93 \\
\hline B & Lead Nitrate & $\mathrm{Pb}\left(\mathrm{NO}_{3}\right)_{2}$ & 0.32 \\
\hline B & Strontium Nitrate & $\mathrm{Sr}\left(\mathrm{NO}_{3}\right)_{2}$ & 0.0377 \\
\hline B & Zinc Nitrate & $\mathrm{Zn}\left(\mathrm{NO}_{3}\right)_{2} \bullet 6 \mathrm{H}_{2} \mathrm{O}$ & 13.432 \\
\hline B & Silver Nitrate & $\mathrm{AgNO}$ & 2.344 \\
\hline
\end{tabular}

The $\mathrm{pH}$ of the simulant was 0.63 after all the metals listed in step B of Table B-9 were added. The metals were precipitated with 8 molar sodium hydroxide by adding the sodium hydroxide solution at $5-10 \mathrm{~mL} / \mathrm{min}$ while agitating at $500-800 \mathrm{rpm}$. Sodium hydroxide addition was continued until the slurry $\mathrm{pH}$ was greater than ten (Table B-2. sequence C). The $\mathrm{pH}$ of the solution was monitored continuously during the addition of sodium hydroxide solution. Mixing 
WSRC-TR-2001-00203, Rev. 0

SRT-RPP-2001-00051, Rev. 0

TRPT-24590-01-00001

was difficult after the $\mathrm{pH}$ had risen above four and fouling of the $\mathrm{pH}$ probe required frequent cleaning to support the $\mathrm{pH}$ measurement. Sodium hydroxide addition was stopped after the $\mathrm{pH}$ was greater than 10. The measured $\mathrm{pH}$ at this point after cleaning the $\mathrm{pH}$ probe was about 11.8. Next twelve liters of 0.6 molar sodium carbonate solution was added (Table B- 2, sequence D) and the sludge slurry mixed for several hours. The slurry was then allowed to settle for 48 hours. The settled volume was about 25 liters.

As in the AZ-101 sludge preparation, batch washing with gravity settling was planned for reducing the soluble species concentration, primarily nitrate. The AZ-102 sludge batch settled well and did not require splitting to achieve a reasonable wash ratio. The first wash for the AZ102 sludge was with deionized water. Subsequent washes were with inhibited water, 0.01 molar in $\mathrm{NaOH}$ and 0.01 molar in $\mathrm{NaNO}_{2}$. Samples of the decanted supernate were analyzed for anions to determine when the washing endpoint was reached. Figure B - 3 shows the nitrate, chloride and nitrite concentrations during each stage of washing.

Figure B - 3 Washing of Precipitated AZ-102 Sludge Simulant Solids

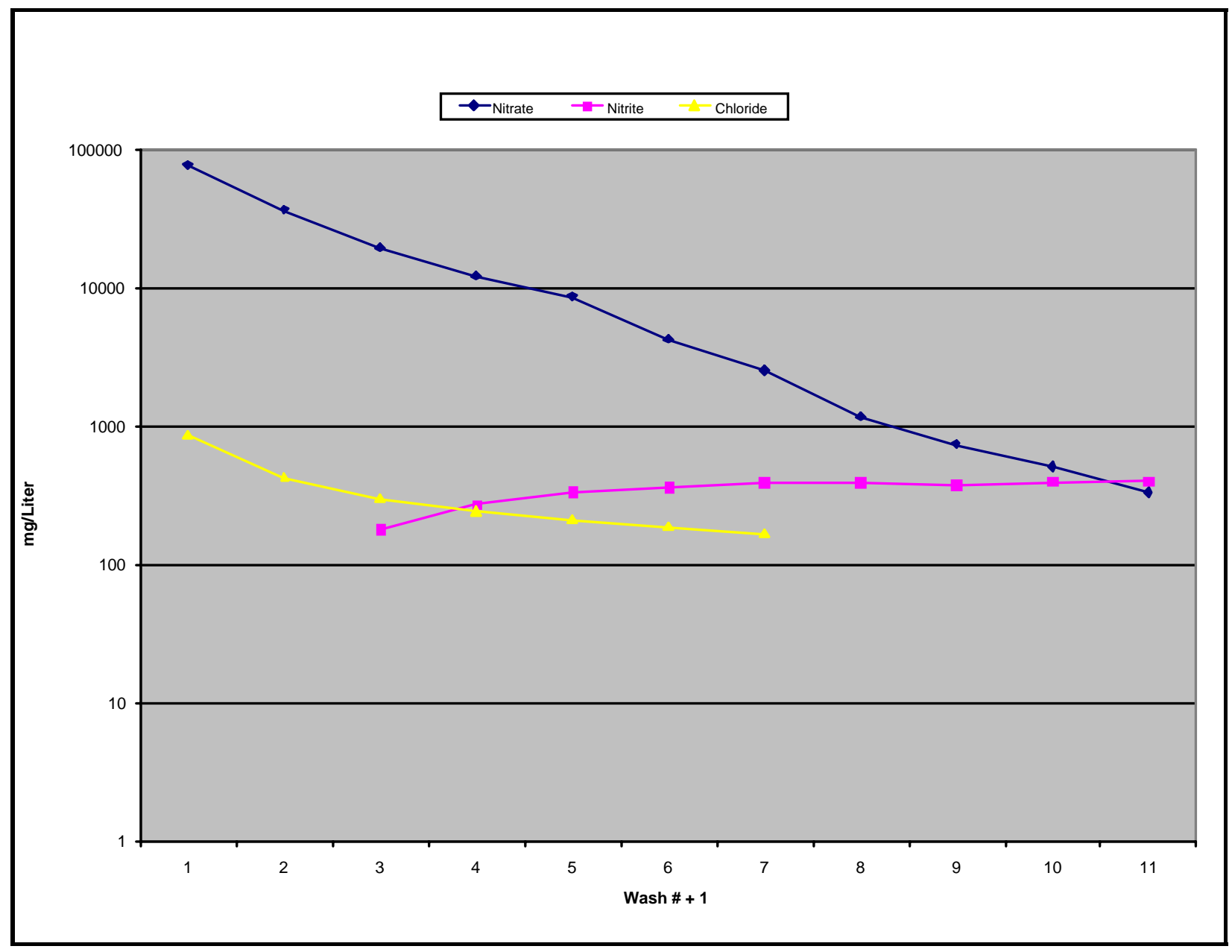

The decanted washes had virtually no color indicating that the transition metals were remaining insoluble during the series of washes. The large number of washes was dictated by the limited 
WSRC-TR-2001-00203, Rev. 0

wash volume that could be obtained at each step, due to the limited free supernate that could be decanted. The settling time for each wash step was generally 18-48 hours.

The final addition of chemicals to the AZ-102 simulated sludge consisted of insoluble solids, which could react with the hydroxide used to precipitate the transition metals, and the soluble salts. Table B-10 lists the sequence and final chemical additions necessary to produce thirty liters of simulated AZ-102 sludge.

Table B- 10: Thirty Liter AZ-102 Simulated Sludge Recipe Part B Final Chemical Additions to AZ-102 Simulated Sludge

\begin{tabular}{|c|l|l|c|}
\hline \multicolumn{2}{|c}{ Sequence Compound } & \multicolumn{1}{c|}{ Formula } & Mass, grams \\
\hline $\mathrm{F}$ & Titanium Dioxide & $\mathrm{TiO}_{2},<5$ micron & 0.775 \\
\hline $\mathrm{F}$ & Silica & $\mathrm{SiO}_{2},<5$ microns & 48.68 \\
\hline $\mathrm{F}$ & Aluminum Oxide & $\mathrm{Al}_{2} \mathrm{O}_{3},<10$ microns & 647.8 \\
\hline $\mathrm{G}$ & Boric Acid & $\mathrm{H}_{3} \mathrm{BO}_{3}$ & 4.180 \\
\hline $\mathrm{G}$ & Sodium Chloride & $\mathrm{NaCl}$ & 6.87 \\
\hline $\mathrm{G}$ & Sodium Fluoride & $\mathrm{NaF}_{2}$ & 2.125 \\
\hline $\mathrm{G}$ & Sodium Sulfate & $\mathrm{Na}_{2} \mathrm{SO}_{4}$ & 5.687 \\
\hline $\mathrm{G}$ & Sodium Phosphate & $\mathrm{Na}_{3} \mathrm{PO}_{4} \bullet 12 \mathrm{H}_{2} \mathrm{O}$ & 110.119 \\
\hline $\mathrm{G}$ & Sodium Nitrite & $\mathrm{NaNO}_{2}$ & 8.412 \\
\hline
\end{tabular}

After the final chemical additions, the sludge was sampled for physical properties and composition. Table B-11 lists the physical properties. The comparison between the target sludge composition and the measured sludge composition on a waste oxide basis is shown in Table B- 12,

Table B- 11: AZ-102 Simulated Sludge Initial Physical Properties

\begin{tabular}{||l|c||}
\hline \hline Weight \% Total Solids & 13.6 \\
\hline Weight \% Soluble Solids & 0.43 \\
\hline Weight \% Insoluble Solids & 13.17 \\
\hline Density at $295 \mathrm{~K}\left(\mathrm{~kg} / \mathrm{m}^{3}\right)$ & 1072 \\
\hline pH of the slurry & 12.03 \\
\hline \hline
\end{tabular}


WSRC-TR-2001-00203, Rev. 0

Table B- 12: Measured Compared to Target AZ-102 Sludge Composition Wt. \% Waste Oxides

\begin{tabular}{|c|c|c|c|c|c|}
\hline \multirow{2}{*}{$\begin{array}{l}\text { Waste } \\
\text { Oxide }\end{array}$} & \multicolumn{2}{|c|}{$\begin{array}{l}\text { Wt. \% waste oxide } \\
\text { Composition }\end{array}$} & \multirow{2}{*}{$\begin{array}{l}\text { Waste } \\
\text { Oxide }\end{array}$} & \multicolumn{2}{|c|}{$\begin{array}{l}\text { Wt. \% waste oxide } \\
\text { Composition }\end{array}$} \\
\hline & Measured & Target & & Measured & Target \\
\hline $\mathrm{Ag}_{2} \mathrm{O}$ & 0.05 & 0.06 & $\mathrm{MnO}$ & 1.06 & 0.90 \\
\hline $\mathrm{Al}_{2} \mathrm{O}_{3}$ & 27.97 & 26.28 & $\mathrm{Na}_{2} \mathrm{O}$ & 3.76 & 13.16 \\
\hline $\mathrm{BaO}$ & 0.16 & 0.14 & $\mathrm{Nd}_{2} \mathrm{O}_{3}$ & 0.05 & 0.04 \\
\hline $\mathrm{CaO}$ & 0.22 & 0.18 & $\mathrm{NiO}$ & 3.08 & 2.68 \\
\hline $\mathrm{CdO}$ & 5.25 & 4.77 & $\mathrm{P}_{2} \mathrm{O}_{5}$ & 1.02 & 0.83 \\
\hline $\mathrm{CeO}_{2}$ & 0.20 & 0.25 & $\mathrm{PbO}$ & $<0.05$ & 0.01 \\
\hline $\mathrm{CoO}$ & 0.03 & 0.02 & $\mathrm{SiO}_{2}$ & 2.44 & 1.97 \\
\hline $\mathrm{Cr}_{2} \mathrm{O}_{3}$ & 0.32 & 0.30 & $\mathrm{SrO}$ & $<0.0006$ & 0.0006 \\
\hline $\mathrm{CuO}$ & $<0.01$ & 0.001 & $\mathrm{TiO}_{2}$ & $<0.50$ & 0.03 \\
\hline $\mathrm{Fe}_{2} \mathrm{O}_{3}$ & 45.87 & 40.99 & $\mathrm{ZnO}$ & 0.18 & 0.15 \\
\hline $\mathrm{La}_{2} \mathrm{O}_{3}$ & 1.20 & 1.08 & $\mathrm{ZrO}_{2}$ & 6.08 & 5.73 \\
\hline $\mathrm{MgO}$ & 0.48 & 0.42 & & & \\
\hline
\end{tabular}

Since the actual Envelope D waste will experience substantial shearing during the crossflow filtration, the washed, simulated AZ-102 sludge was sheared by pumping the simulant through a pump typically used for a small crossflow filter. The same process of shearing was used that was described for the simulated AZ-101 sludge. Thus, for the 30 liter AZ-102 batch, 10 hours of recirculation using the CUF pump was used to apply the appropriate amount of shearing. Samples of the simulated sludge before and after shearing were analyzed for particle size, and the results are shown in Table B-13.

Table B- 13: Particle Size Shearing Results for AZ-102 Simulated Sludge

\begin{tabular}{|l|c|c|}
\hline & Before Shearing & After Shearing \\
\hline Mean Particle Size by Volume & $\mathbf{1 8 . 6 9}$ microns & 11.55 microns \\
Mean Particle Size by Number & $\mathbf{2 . 7 5}$ microns & 1.38 microns \\
Largest Particles & $\mathbf{2 4 9}$ micron & $\mathbf{1 7 6}$ micron \\
\hline
\end{tabular}

Different solids concentrations of AZ-102 simulated sludge were obtained by centrifuging at $42500 \mathrm{~m} / \mathrm{s}^{2}$ and adding back the amount of supernate to achieve the desired solids loading. The residual supernate was retained for use in diluting to lower solids loadings. The slurries prepared are listed in Table 6 .

\section{AN-107 Sr/TRU Precipitate Simulant}

The AN-107 Sr/TRU precipitate simulant was produced by applying the Sr/TRU process to an AN-107 supernate simulant containing entrained solids. The AN-107 supernate simftanthas been previously described, and is based on recent samples from tank 241-AN-107.26 29.

${ }^{29}$ R. A. Esch, Tank Waste Remediation System (TWRS) Privatization Private Contractor samples Waste Envelope C Material Tank 241-AN-107, HNF-SD-WM-DP-205, Rev. 1, Rust Federal Services of Hanford, Inc., Richland, WA 99352 (April 8, 1997). 
WSRC-TR-2001-00203, Rev. 0

SRT-RPP-2001-00051, Rev. 0

TRPT-24590-01-00001

AN-107 entrained solids simulant was produced by the following sequence of reactions and mixing steps shown in previously described.26

Table B- 14: Sequence of Making AN-107 Entrained Solids Simulant

\begin{tabular}{|c|l|}
\hline Sequence & Reaction \\
\hline A & $\begin{array}{l}\text { The transition metal nitrates, complexing chemicals and nonreactive salts are dissolved } \\
\text { with sufficient water to create a solution. }\end{array}$ \\
\hline B & $\begin{array}{l}\text { A second solution is prepared by reacting sodium hydroxide with aluminum nitrate and } \\
\text { adding additional salts }\end{array}$ \\
\hline C & The solutions prepared in steps A and B are combined. \\
\hline D & $\begin{array}{l}\text { Addition of the three remaining salts, sodium carbonate, sodium nitrate and sodium } \\
\text { nitrite, are made along with the remaining water necessary to achieve the required } \\
\text { concentrations based upon solution density. }\end{array}$ \\
\hline E & $\begin{array}{l}\text { The solution is mixed overnight to dissolve the final salts. } \\
\text { The entrained solids compounds are added to the simulant and the slurry is mixed for } \\
\text { several hours to thoroughly disperse the entrained solids Add hydroxide-reactive insoluble } \\
\text { species of known particle size. }\end{array}$ \\
\hline
\end{tabular}

A forty-liter batch of the AN-107 simulant was produced at 5.5 molar sodium concentration by the recipe given in Table B-15. After mixing the supernate simulant overnight, the entrained solids listed in Table B-16 were added to the solution. The entrained solids represent unwashed solids, which are $0.5 \mathrm{wt}$. \% of the total mass of the final solution. Based upon a planned solution density of $1.243 \mathrm{~g} / \mathrm{mL}$ and 40 liters of solution, 248.6 grams of solids were added. Additional alumina and silica were added to represent the sodium aluminosilicate, since none of the latter reagent was available, and these quantities are listed in Table B-16.

\footnotetext{
30 J. A. Campbell, S. A. Clauss, K. E. Grant, V. Hoopes, G. M. Mong, R. Steele, D. Bellofatto, A. Sharma, Organic Tanks Safety Program Organic Analysis Progress Report FY 1997, PNNL-11738, UC-601, Pacific Northwest National Laboratory, Richland, WA 99352 (April 1998).
} 
WSRC-TR-2001-00203, Rev. 0

SRT-RPP-2001-00051, Rev. 0

TRPT-24590-01-00001

Table B- 15: Forty Liter AN-107 Supernate Simulant Recipe

\begin{tabular}{|c|c|c|c|}
\hline Sequence & Compound & Formula & Mass, grams \\
\hline $\mathrm{A}$ & Water & $\mathrm{H}_{2} \mathrm{O}$ & 8002.0 \\
\hline A & Calcium Nitrate & $\mathrm{Ca}\left(\mathrm{NO}_{3}\right)_{2} \bullet 4 \mathrm{H}_{2} \mathrm{O}$ & 87.34 \\
\hline $\mathrm{A}$ & Cerium Nitrate & $\mathrm{Ce}\left(\mathrm{NO}_{3}\right)_{3} \bullet 6 \mathrm{H}_{2} \mathrm{O}$ & 4.13 \\
\hline $\mathrm{A}$ & Cesium Nitrate & $\mathrm{CsNO}_{3}$ & 0.68 \\
\hline A & Copper Nitrate & $\mathrm{Cu}\left(\mathrm{NO}_{3}\right)_{2} \bullet 6 \mathrm{H}_{2} \mathrm{O}$ & 2.88 \\
\hline A & Ferric Nitrate & $\mathrm{Fe}\left(\mathrm{NO}_{3}\right)_{3} \bullet 9 \mathrm{H}_{2} \mathrm{O}$ & 306.80 \\
\hline $\mathrm{A}$ & Lanthanum Nitrate & $\mathrm{La}\left(\mathrm{NO}_{3}\right)_{3} \bullet 6 \mathrm{H}_{2} \mathrm{O}$ & 3.67 \\
\hline $\mathrm{A}$ & Lead Nitrate & $\mathrm{Pb}\left(\mathrm{NO}_{3}\right)_{2}$ & 15.56 \\
\hline $\mathrm{A}$ & Magnesium Nitrate & $\mathrm{Mg}\left(\mathrm{NO}_{3}\right)_{2} \bullet 6 \mathrm{H}_{2} \mathrm{O}$ & 6.63 \\
\hline A & Manganous Chloride & $\mathrm{MnCl}_{2} \bullet 4 \mathrm{H}_{2} \mathrm{O}$ & 50.88 \\
\hline A & Neodymium Nitrate & $\mathrm{Nd}\left(\mathrm{NO}_{3}\right)_{3} \bullet 6 \mathrm{H}_{2} \mathrm{O}$ & 7.31 \\
\hline $\mathrm{A}$ & Nickel Chloride & $\mathrm{NiCl}_{2} \bullet 6 \mathrm{H}_{2} \mathrm{O}$ & 53.85 \\
\hline A & Potassium Nitrate & $\mathrm{KNO}_{3}$ & 115.51 \\
\hline A & Strontium Nitrate & $\mathrm{Sr}\left(\mathrm{NO}_{3}\right)_{2}$ & 0.47 \\
\hline $\mathrm{A}$ & Zinc Nitrate & $\mathrm{Zn}\left(\mathrm{NO}_{3}\right)_{2} \bullet 6 \mathrm{H}_{2} \mathrm{O}$ & 5.37 \\
\hline A & Zirconyl Nitrate & $\mathrm{ZrO}\left(\mathrm{NO}_{3}\right)_{2} \bullet \mathrm{xH}_{2} \mathrm{O} \times \sim 1$ & 4.87 \\
\hline $\bar{A}$ & $\begin{array}{l}\text { Disodium } \\
\text { ethylenediaminetetraacetate }\end{array}$ & $\mathrm{Na}_{2} \mathrm{C}_{10} \mathrm{H}_{14} \mathrm{~N}_{2} \mathrm{O}_{8} \bullet 2 \mathrm{H}_{2} \mathrm{O}$ & 182.18 \\
\hline A & $\begin{array}{l}\mathrm{N}-(2 \text {-Hydroxyethyl) } \\
\text { ethylenediaminetriacetic acid }\end{array}$ & $\mathrm{C}_{10} \mathrm{H}_{18} \mathrm{~N}_{2} \mathrm{O}_{7}$ & 54.27 \\
\hline A & Sodium Gluconate & $\mathrm{HOCH}_{2}[\mathrm{CH}(\mathrm{OH})]_{4} \mathrm{CO}_{2} \mathrm{Na}$ & 98.64 \\
\hline $\mathrm{A}$ & Glycolic Acid & $\mathrm{HOCH}_{2} \mathrm{CO}_{2} \mathrm{H}, 70$ wt $\%$ & 675.51 \\
\hline $\mathrm{A}$ & Citric Acid & $\mathrm{HOC}\left(\mathrm{CO}_{2} \mathrm{H}\right)\left(\mathrm{CH}_{2} \mathrm{CO}_{2} \mathrm{H}\right)_{2} \bullet \mathrm{H}_{2} \mathrm{O}$ & 236.79 \\
\hline A & Nitrilotriacetic Acid & $\mathrm{N}\left(\mathrm{CH}_{2} \mathrm{CO}_{2} \mathrm{H}\right)_{3}$ & 14.29 \\
\hline $\mathrm{A}$ & Iminodiacetic Acid & $\mathrm{HN}\left(\mathrm{CH}_{2} \mathrm{CO}_{2} \mathrm{H}\right)_{2}$ & 151.50 \\
\hline $\mathrm{A}$ & Boric Acid & $\mathrm{H}_{3} \mathrm{BO}_{3}$ & 5.04 \\
\hline $\mathrm{A}$ & Sodium Chloride & $\mathrm{NaCl}$ & 19.11 \\
\hline $\mathrm{A}$ & Sodium Fluoride & $\mathrm{NaF}$ & 7.36 \\
\hline $\mathrm{A}$ & Sodium Chromate & $\mathrm{Na}_{2} \mathrm{CrO}_{4}$ & 13.90 \\
\hline $\mathrm{A}$ & Sodium Sulfate & $\mathrm{Na}_{2} \mathrm{SO}_{4}$ & 306.16 \\
\hline $\mathrm{A}$ & Potassium Molybdate & $\mathrm{K}_{2} \mathrm{MoO}_{4}$ & 2.20 \\
\hline $\mathrm{B}$ & Water & $\mathrm{H}_{2} \mathrm{O}$ & 8002.6 \\
\hline $\mathrm{B}$ & Sodium Hydroxide & $\mathrm{NaOH}$ & 633.76 \\
\hline $\mathrm{B}$ & Aluminum Nitrate & $\mathrm{Al}\left(\mathrm{NO}_{3}\right)_{3} \bullet 9 \mathrm{H}_{2} \mathrm{O}$ & 134.63 \\
\hline $\mathrm{B}$ & Sodium Phosphate & $\mathrm{Na}_{3} \mathrm{PO}_{4} \bullet 12 \mathrm{H}_{2} \mathrm{O}$ & 111.46 \\
\hline $\mathrm{B}$ & Sodium Formate & $\mathrm{NaHCOO}$ & 394.17 \\
\hline $\mathrm{B}$ & Sodium Acetate & $\mathrm{NaCH}_{3} \mathrm{CO}_{2} \bullet 12 \mathrm{H}_{2} \mathrm{O}$ & 59.43 \\
\hline $\mathrm{B}$ & Sodium Oxalate & $\mathrm{Na}_{2} \mathrm{C}_{2} \mathrm{O}_{4}$ & 31.54 \\
\hline $\mathrm{D}$ & Sodium Carbonate & $\mathrm{Na}_{2} \mathrm{CO}_{3}$ & 3720.0 \\
\hline $\mathrm{D}$ & Sodium Nitrate & $\mathrm{NaNO}_{3}$ & 7517.2 \\
\hline $\mathrm{D}$ & Sodium Nitrite & $\mathrm{NaNO}_{2}$ & 2295.3 \\
\hline D & Water & $\mathrm{H}_{2} \mathrm{O}$ & 16444.0 \\
\hline
\end{tabular}


WSRC-TR-2001-00203, Rev. 0

SRT-RPP-2001-00051, Rev. 0

TRPT-24590-01-00001

Table B- 16: Forty Liter AN-107 Entrained Solids Simulant

\begin{tabular}{|c|c|c|c|}
\hline Sequence & Compound & Formula & Mass, grams \\
\hline $\mathrm{F}$ & Aluminum Oxide & $\mathrm{Al}_{2} \mathrm{O}_{3},<10$ microns & 12.93 \\
\hline $\mathrm{F}$ & Calcium Phosphate, tribasic & $\mathrm{Ca}_{3} \mathrm{PO}_{4}$ & 0.181 \\
\hline $\bar{F}$ & Chromic Oxide & $\mathrm{Cr}_{2} \mathrm{O}_{3},<10$ microns & 0.965 \\
\hline $\mathrm{F}$ & Ferric Oxide & $\mathrm{Fe}_{2} \mathrm{O}_{3}$ & 12.0 \\
\hline $\mathrm{F}$ & Manganese Dioxide & $\mathrm{MnO}_{2}$ & 7.77 \\
\hline $\mathrm{F}$ & Silica & $\mathrm{SiO}_{2},<5$ microns & 1.308 \\
\hline $\mathrm{F}$ & Sodium Oxalate & $\mathrm{Na}_{2} \mathrm{C}_{2} \mathrm{O}_{4}$ & 85.98 \\
\hline $\mathrm{F}$ & Sodium Carbonate Monohydrate & $\mathrm{Na}_{2} \mathrm{CO}_{3} \bullet \mathrm{H} 2 \mathrm{O}$ & 81.29 \\
\hline $\mathrm{F}$ & Sodium Fluoride & $\mathrm{NaF}$ & 12.59 \\
\hline $\mathrm{F}$ & Sodium Sulfate & $\mathrm{Na}_{2} \mathrm{SO}_{4} \bullet 10 \mathrm{H}_{2} \mathrm{O}$ & 10.41 \\
\hline $\mathrm{F}$ & Sodium Phosphate & $\mathrm{Na}_{3} \mathrm{PO}_{4} \bullet 12 \mathrm{H}_{2} \mathrm{O}$ & 23.29 \\
\hline
\end{tabular}

\section{Sr/TRU Precipitation}

The Sr/TRU precipitation consisted of raising the hydroxide level of the solution to one molar. The next step was adding strontium nitrate to precipitate strontium carbonate followed by sodium permanganate to react with the complexing agents. The slurry is digested at $323 \mathrm{~K}$ for 4 hours to complete the reactions due to permanganate anion and the complexing agents. The sequence of steps is listed in Table B-17.

\section{Table B- 17: Sr/TRU Precipitation Process}

\begin{tabular}{|c|l|}
\hline Sequence & Reaction \\
\hline A & $\begin{array}{l}\text { Add sufficient sodium hydroxide to increase free hydroxide concentration to 1.0 } \pm 0.2 \\
\text { molar. Mix thoroughly. }\end{array}$ \\
\hline B & $\begin{array}{l}\text { Add the amount of 2 molar strontium nitrate solution needed to increase the strontium } \\
\text { concentration to 0.075 molar. The addition was made over a 5 to } 10 \text { minute period while } \\
\text { mixing the solution. }\end{array}$ \\
\hline C & $\begin{array}{l}\text { Add the amount of 1 molar sodium permanganate solution needed to increase the } \\
\text { permanganate concentration to 0.05 molar. The addition was made over a 5 to } 10 \text { minute } \\
\text { period while mixing the solution. }\end{array}$ \\
\hline D & $\begin{array}{l}\text { The Sr/TRU precipitated slurry is heated to 323 } 5 \text { K for four hours while being } \\
\text { continuously stirred. }\end{array}$ \\
\hline E & $\begin{array}{l}\text { The slurry was allowed to cool to ambient lab temperatures (295 K) overnight while } \\
\text { stirring continued. }\end{array}$ \\
\hline F & $\begin{array}{l}\text { Separate precipitate from decontaminated supernate and wash the solids four times with } \\
\text { equal volumes of inhibited (0.01 molar hydroxide) wash water }\end{array}$ \\
\hline
\end{tabular}

The free hydroxide concentration in AN-107 supernate is less than 0.02 molar. Therefore, the amount of sodium hydroxide required for a forty liter batch was 40 moles. Assuming the solution volumes were additive, the amounts of strontium nitrate solution and sodium permanganate solution required were 1.644 liters and 2.192 liters, respectively. The actual amounts used are listed in Table B-18. 
WSRC-TR-2001-00203, Rev. 0

SRT-RPP-2001-00051, Rev. 0

TRPT-24590-01-00001

Table B- 18: Sr/TRU Precipitate Batching for Forty Liter AN-107 Batch

\begin{tabular}{||c|c|c|c||}
\hline Reactant & Concentration & Density, $\mathrm{kg} / \mathrm{m}^{3}$ & Mass Used, $\mathrm{kg}$ \\
\hline Sodium Hydroxide & Solid & -- & 1.6000 \\
\hline Strontium Nitrate & 2 Molar & 1285 & 2.1129 \\
\hline Sodium Permanganate & 1 Molar & 1096 & 2.4023 \\
\hline
\end{tabular}

In the WTP, the decontaminated Envelope C supernate is separated from the Sr/TRU precipitate by crossflow filtration. Since a crossflow system was not available for this study, the precipitate was initially allowed to separate from the supernate by gravity settling. After decanting the supernate, the remaining slurry was concentrated by centrifuging the slurry at $42500 \mathrm{~m} / \mathrm{s}^{2}$ to yield a slurry with nominally $15 \mathrm{wt} \%$ insoluble solids. The measured properties of the initial unwashed Sr/TRU precipitate slurry are listed in Table B-19.

Table B- 19: Initial Sr/TRU Unwashed Precipitate Physical Properties

\begin{tabular}{||l|c||}
\hline Weight \% Total Solids & 40.92 \\
\hline Weight \% Soluble Solids & 25.14 \\
\hline Weight \% Insoluble Solids & 15.77 \\
\hline Density at $295 \mathrm{~K}$ in g/mL & 1.452 \\
\hline
\end{tabular}

The rheology of the unwashed Sr/TRU precipitate was analyzed on the Haake M5 rheometer using the MV1 sensor. The results will be discussed in the results section. The precipitate was washed four times to reduce the soluble solids loading. The Sr/TRU precipitate in the WTP would be sheared by the pumps used for the crossflow filtration of the precipitate similar to the Envelope D preparations. The same process of shearing as described in processing the simulated AZ0-101 sludge was used. A period of 3.3 hours of recirculation using the CUF pump was used to apply the appropriate amount of shearing for the approximate $10 \mathrm{~L}$ of Sr/TRU precipitate.

During the shearing process, more than $55 \%$ of the batch was inadvertently lost. Since insufficient Sr/TRU precipitate remained for the study, an additional thirty liter batch of AN-107 simulant was prepared and processed through the SR/TRU process. The recipe for the second batch of AN-107 simulant is listed in Table B- 20 and Table B-21. 
WSRC-TR-2001-00203, Rev. 0

SRT-RPP-2001-00051, Rev. 0

TRPT-24590-01-00001

Table B- 20: Thirty Liter AN-107 Supernate Simulant Recipe (Batch 2)

\begin{tabular}{|c|c|c|c|}
\hline Sequence & Compound & Formula & Mass, grams \\
\hline $\mathrm{A}$ & Water & $\mathrm{H}_{2} \mathrm{O}$ & 5999.9 \\
\hline A & Calcium Nitrate & $\mathrm{Ca}\left(\mathrm{NO}_{3}\right)_{2} \bullet 4 \mathrm{H}_{2} \mathrm{O}$ & 65.5 \\
\hline A & Cerium Nitrate & $\mathrm{Ce}\left(\mathrm{NO}_{3}\right)_{3} \bullet 6 \mathrm{H}_{2} \mathrm{O}$ & 3.09 \\
\hline $\mathrm{A}$ & Cesium Nitrate & $\mathrm{CsNO}_{3}$ & 0.5133 \\
\hline A & Copper Nitrate & $\mathrm{Cu}\left(\mathrm{NO}_{3}\right)_{2} \bullet 6 \mathrm{H}_{2} \mathrm{O}$ & 2.15 \\
\hline A & Ferric Nitrate & $\mathrm{Fe}\left(\mathrm{NO}_{3}\right)_{3} \bullet 9 \mathrm{H}_{2} \mathrm{O}$ & 230.00 \\
\hline $\mathrm{A}$ & Lanthanum Nitrate & $\mathrm{La}\left(\mathrm{NO}_{3}\right)_{3} \bullet 6 \mathrm{H}_{2} \mathrm{O}$ & 2.68 \\
\hline A & Lead Nitrate & $\mathrm{Pb}\left(\mathrm{NO}_{3}\right)_{2}$ & 11.68 \\
\hline $\mathrm{A}$ & Magnesium Nitrate & $\mathrm{Mg}\left(\mathrm{NO}_{3}\right)_{2} \bullet 6 \mathrm{H}_{2} \mathrm{O}$ & 4.97 \\
\hline A & Manganous Chloride & $\mathrm{MnCl}_{2} \bullet 4 \mathrm{H}_{2} \mathrm{O}$ & 38.17 \\
\hline A & Neodymium Nitrate & $\mathrm{Nd}\left(\mathrm{NO}_{3}\right)_{3} \bullet 6 \mathrm{H}_{2} \mathrm{O}$ & 5.48 \\
\hline A & Nickel Chloride & $\mathrm{NiCl}_{2} \cdot 6 \mathrm{H}_{2} \mathrm{O}$ & 49.41 \\
\hline A & Potassium Nitrate & $\mathrm{KNO}_{3}$ & 86.64 \\
\hline A & Strontium Nitrate & $\mathrm{Sr}\left(\mathrm{NO}_{3}\right)_{2}$ & 0.300 \\
\hline $\mathrm{A}$ & Zinc Nitrate & $\mathrm{Zn}\left(\mathrm{NO}_{3}\right)_{2} \bullet 6 \mathrm{H}_{2} \mathrm{O}$ & 3.89 \\
\hline $\mathrm{A}$ & Zirconyl Nitrate & $\mathrm{ZrO}\left(\mathrm{NO}_{3}\right)_{2} \bullet \mathrm{xH}_{2} \mathrm{O} \times \sim 1$ & 3.60 \\
\hline A & $\begin{array}{l}\text { Disodium } \\
\text { ethylenediaminetetraacetate }\end{array}$ & $\mathrm{Na}_{2} \mathrm{C}_{10} \mathrm{H}_{14} \mathrm{~N}_{2} \mathrm{O}_{8} \bullet 2 \mathrm{H}_{2} \mathrm{O}$ & 136.6 \\
\hline A & $\begin{array}{l}\mathrm{N}-(2-\text { Hydroxyethyl }) \\
\text { ethylenediaminetriacetic acid }\end{array}$ & $\mathrm{C}_{10} \mathrm{H}_{18} \mathrm{~N}_{2} \mathrm{O}_{7}$ & 40.70 \\
\hline A & Sodium Gluconate & $\mathrm{HOCH}_{2}[\mathrm{CH}(\mathrm{OH})]_{4} \mathrm{CO}_{2} \mathrm{Na}$ & 73.88 \\
\hline $\mathrm{A}$ & Glycolic Acid & $\mathrm{HOCH}_{2} \mathrm{CO}_{2} \mathrm{H}, 70 \mathrm{wt} \%$ & 506.6 \\
\hline A & Citric Acid & $\mathrm{HOC}\left(\mathrm{CO}_{2} \mathrm{H}\right)\left(\mathrm{CH}_{2} \mathrm{CO}_{2} \mathrm{H}_{2}\right)_{2} \cdot \mathrm{H}_{2} \mathrm{O}$ & 177.6 \\
\hline A & Nitrilotriacetic Acid & $\mathrm{N}\left(\mathrm{CH}_{2} \mathrm{CO}_{2} \mathrm{H}\right)_{3}$ & 10.72 \\
\hline $\mathrm{A}$ & Iminodiacetic Acid & $\mathrm{HN}\left(\mathrm{CH}_{2} \mathrm{CO}_{2} \mathrm{H}\right)_{2}$ & 113.6 \\
\hline $\mathrm{A}$ & Boric Acid & $\mathrm{H}_{3} \mathrm{BO}_{3}$ & 3.77 \\
\hline A & Sodium Chloride & $\mathrm{NaCl}$ & 34.23 \\
\hline A & Sodium Fluoride & $\mathrm{NaF}$ & 5.53 \\
\hline A & Sodium Chromate & $\mathrm{Na}_{2} \mathrm{CrO}_{4}$ & 10.31 \\
\hline $\mathrm{A}$ & Sodium Sulfate & $\mathrm{Na}_{2} \mathrm{SO}_{4}$ & 229.5 \\
\hline $\mathrm{A}$ & Potassium Molybdate & $\mathrm{K}_{2} \mathrm{MoO}_{4}$ & 1.67 \\
\hline $\mathrm{B}$ & Water & $\mathrm{H}_{2} \mathrm{O}$ & 6000.0 \\
\hline $\mathrm{B}$ & Sodium Hydroxide & $\mathrm{NaOH}$ & 475.3 \\
\hline $\mathrm{B}$ & Aluminum Nitrate & $\mathrm{Al}\left(\mathrm{NO}_{3}\right)_{3} \bullet 9 \mathrm{H}_{2} \mathrm{O}$ & 100.9 \\
\hline $\mathrm{B}$ & Sodium Phosphate & $\mathrm{Na}_{3} \mathrm{PO}_{4} \bullet 12 \mathrm{H}_{2} \mathrm{O}$ & 83.59 \\
\hline $\mathrm{B}$ & Sodium Formate & $\mathrm{NaHCOO}$ & 295.6 \\
\hline $\mathrm{B}$ & Sodium Acetate & $\mathrm{NaCH}_{3} \mathrm{CO}_{2} \bullet 12 \mathrm{H}_{2} \mathrm{O}$ & 44.57 \\
\hline B & Sodium Oxalate & $\mathrm{Na}_{2} \mathrm{C}_{2} \mathrm{O}_{4}$ & 23.67 \\
\hline $\mathrm{D}$ & Sodium Carbonate & $\mathrm{Na}_{2} \mathrm{CO}_{3}$ & 2789.2 \\
\hline $\mathrm{D}$ & Sodium Nitrate & $\mathrm{NaNO}_{3}$ & 5593.3 \\
\hline $\mathrm{D}$ & Sodium Nitrite & $\mathrm{NaNO}_{2}$ & 1721.6 \\
\hline $\mathrm{D}$ & Water & $\mathrm{H}_{2} \mathrm{O}$ & 12330.9 \\
\hline
\end{tabular}


Table B- 21: Thirty Liter AN-107 Entrained Solids Simulant (Batch 2)

\begin{tabular}{|l|l|l|c|}
\hline Sequence & Compound & Formula & Mass, grams \\
\hline F & Aluminum Oxide & $\mathrm{Al}_{2} \mathrm{O}_{3},<10$ microns & 9.58 \\
\hline F & Calcium Phosphate, tribasic & $\mathrm{Ca}_{3} \mathrm{PO}_{4}$ & 0.144 \\
\hline F & Chromic Oxide & $\mathrm{Cr}_{2} \mathrm{O}_{3},<10$ microns & 0.711 \\
\hline F & Ferric Oxide & $\mathrm{Fe}_{2} \mathrm{O}_{3}$ & 8.90 \\
\hline F & Manganese Dioxide & $\mathrm{MnO}_{2}$ & 5.76 \\
\hline F & Silica & $\mathrm{SiO}_{2},<5$ microns & 3.032 \\
\hline F & Sodium Oxalate & $\mathrm{Na}_{2} \mathrm{C}_{2} \mathrm{O}_{4}$ & 63.76 \\
\hline F & Sodium Carbonate Monohydrate & $\mathrm{Na}_{2} \mathrm{CO}_{3} \bullet \mathrm{H} 2 \mathrm{O}$ & 60.29 \\
\hline F & Sodium Fluoride & $\mathrm{NaF}_{2}$ & 9.33 \\
\hline F & Sodium Sulfate & $\mathrm{Na}_{2} \mathrm{SO}_{4} \bullet 10 \mathrm{H}_{2} \mathrm{O}$ & 7.72 \\
\hline F & $\mathrm{Na}_{3} \mathrm{PO}_{4} \bullet 12 \mathrm{H}_{2} \mathrm{O}$ & 17.26 \\
\hline
\end{tabular}

The silica shown in Table B- 21 reflects an inadvertently high addition of silica to the entrained solids for the second batch of Sr/TRU precipitate. The higher level of silica was not expected to have any effect on the precipitate rheology since the insoluble portion of the entrained solids makes up a small fraction of the total insoluble solids in the precipitate. The second batch of AN-107 simulant was processed through the Sr/TRU precipitation steps as previously described, concentrated, washed and combined with the remaining precipitate from the first batch. The precipitate was sheared as previously described to represent the shearing from crossflow filtration. The particle size of the Sr/TRU precipitate was analyzed before and after shearing and is summarized in Table B-22. More details on the particle size distribution can be found in the appendix.

Table B- 22: Particle Size of Washed Sr/TRU Product

\begin{tabular}{|l|c|c|}
\hline & Before Shearing & After Shearing \\
\hline Mean Particle Size by Volume & $\mathbf{1 2 . 0 5}$ microns & $\mathbf{4 . 7 6}$ microns \\
Mean Particle Size by Number & $\mathbf{1 . 3 1}$ microns & $\mathbf{1 . 2}$ microns \\
Largest Particles & $\mathbf{1 7 6}$ micron & $\mathbf{3 1}$ micron \\
\hline
\end{tabular}

The composition of the Sr/TRU product based upon analysis is listed in Table B- 23 on a weight percent oxide basis. As expected, the major components are $\mathrm{Sr}$ and $\mathrm{Mn}$. Other important elements include in descending order: $\mathrm{Na}, \mathrm{Fe}, \mathrm{Al}$ and $\mathrm{Ca}$. 
Table B- 23: Composition of Sr/TRU Precipitate

\begin{tabular}{|c|c|c|c|c|}
\hline Element & Analysis, $\mu g / g m$ & Oxide & Oxide, $\mu g / g m$ & Oxide wt $\%$ \\
\hline $\mathrm{Al}$ & 1960 & $\mathrm{Al}_{2} \mathrm{O}_{3}$ & 3703 & 2.66 \\
\hline $\mathrm{Ba}$ & 34 & $\mathrm{BaO}$ & 38 & 0.03 \\
\hline $\mathrm{Ca}$ & 1950 & $\mathrm{CaO}$ & 2728 & 1.96 \\
\hline $\mathrm{Cd}$ & 1.5 & $\mathrm{CdO}$ & 1.7 & 0.00 \\
\hline $\mathrm{Ce}$ & 445 & $\mathrm{Ce}_{2} \mathrm{O}_{3}$ & 521 & 0.37 \\
\hline $\mathrm{Cr}$ & 221 & $\mathrm{Cr}_{2} \mathrm{O}_{3}$ & 323 & 0.23 \\
\hline $\mathrm{Cu}$ & 23 & $\mathrm{CuO}$ & 29 & 0.02 \\
\hline $\mathrm{Fe}$ & 8034 & $\mathrm{Fe}_{2} \mathrm{O}_{3}$ & 11487 & 8.26 \\
\hline $\mathrm{K}$ & 59 & $\mathrm{~K} 2 \mathrm{O}$ & 71 & 0.05 \\
\hline $\mathrm{La}$ & 182 & $\mathrm{La}_{2} \mathrm{O}_{3}$ & 213 & 0.15 \\
\hline $\mathrm{Mg}$ & 64 & $\mathrm{MgO}$ & 107 & 0.08 \\
\hline $\mathrm{Mn}$ & 22200 & $\mathrm{MnO}$ & 28665 & 20.62 \\
\hline $\mathrm{Na}$ & 12591 & $\mathrm{Na}_{2} \mathrm{O}$ & 16972 & 12.21 \\
\hline $\mathrm{Nd}$ & 350 & $\mathrm{Nd}_{2} \mathrm{O}_{3}$ & 408 & 0.29 \\
\hline $\mathrm{Ni}$ & 29 & $\mathrm{NiO}$ & 37 & 0.03 \\
\hline $\mathrm{P}$ & 412 & $\mathrm{P}_{2} \mathrm{O}_{5}$ & 944 & 0.68 \\
\hline $\mathrm{Pb}$ & 1010 & $\mathrm{PbO}$ & 1088 & 0.78 \\
\hline $\mathrm{Si}$ & 122 & $\mathrm{SiO}_{2}$ & 261 & 0.19 \\
\hline $\mathrm{Sr}$ & 60300 & $\mathrm{SrO}$ & 71311 & 51.30 \\
\hline $\mathrm{Zn}$ & 48 & $\mathrm{ZnO}$ & 59 & 0.04 \\
\hline $\mathrm{Zr}$ & 34 & $\mathrm{ZrO}_{2}$ & 46 & 0.03 \\
\hline
\end{tabular}

Different solids concentrations of Sr/TRU precipitate were obtained by centrifuging at 42500 $\mathrm{m} / \mathrm{s}^{2}$ and adding back sufficient supernate to achieve the desired solids loading. The residual supernate was retained for use in diluting to lower solids loadings. The slurries prepared are listed in Table 9.

\section{Blended Eluate Simulant}

The third process stream which is blended with the washed sludge and Sr/TRU precipitate streams is the blended eluate stream. The stream is a blend of the concentrated eluates from the cesium and technetium ion exchange columns. The Cs column is eluted with nitric acid and Tc column is eluted with water. Both eluates are concentrated by vacuum evaporation and then blended together. Currently, both ion exchange columns and both evaporators have only been independently tested. The combined processes have been modeled using the Environmental Simulation Program version 6.2 licensed by OLI Systems, Inc. 31 The model was applied to the results of ion exchange studies on AZ-102 supernate to obtain the output listed in Table B-43 of Appendix $\mathrm{B}$ of this report. The basis for the simulant was derived from the composition of the blended eluate stream and is shown in Table B- 24.

\footnotetext{
31 A. S. Choi, Estimation of Physical Properties of AN-107 Cesium and Technetium Eluate Blend, WSRC-TR-2000-00527, SRT-RPP2000-00061, Westinghouse Savannah River Company, Aiken, SC 29808 (February 26, 2001).
} 
WSRC-TR-2001-00203, Rev. 0

SRT-RPP-2001-00051, Rev. 0

TRPT-24590-01-00001

Table B- 24: Derived Analytical Composition of Blended Eluate

\begin{tabular}{|c|c|c|c|c|c|}
\hline Component & $\mathrm{g} / \mathrm{L}$ & Molar & Component & $\mathrm{g} / \mathrm{L}$ & Molar \\
\hline Boron & 0.171 & $1.58 \mathrm{E}-02$ & Nitrate & 71.037 & 1.15 \\
\hline Calcium & 0.001 & $1.32 \mathrm{E}-05$ & Nitrite & 10.929 & $2.38 \mathrm{E}-01$ \\
\hline Carbonate & 1.06 & $1.77 \mathrm{E}-02$ & Oxalate & 4.382 & $4.98 \mathrm{E}-02$ \\
\hline Bicarbonate & 7.845 & $1.29 \mathrm{E}-01$ & Hydrogen Phosphate & 0.464 & $4.84 \mathrm{E}-03$ \\
\hline Cesium & 1.826 & $1.37 \mathrm{E}-02$ & Dihydrogen Phosphate & 0.016 & $1.16 \mathrm{E}-04$ \\
\hline Chloride & 6.487 & $1.83 \mathrm{E}-01$ & Potassium & 1.486 & $3.8 \mathrm{E}-02$ \\
\hline Chromium & 0.509 & $9.79 \mathrm{E}-03$ & Silicon & 0.122 & $8.71 \mathrm{E}-03$ \\
\hline EDTA & 0.199 & $6.9 \mathrm{E}-04$ & Sodium & 46.95 & 2.04 \\
\hline Glycolate & 0.437 & $5.82 \mathrm{E}-03$ & Sulfate & 10.99 & $2.29 \mathrm{E}-01$ \\
\hline Hydroxide & 0.005 & $3.23 \mathrm{E}-04$ & Citric Acid & 0.219 & $1.14 \mathrm{E}-03$ \\
\hline Iron & 0.004 & $7.79 \mathrm{E}-05$ & Nitrilotriacetic Acid & 0.013 & $6.92 \mathrm{E}-05$ \\
\hline Lead & 0.055 & $2.67 \mathrm{E}-04$ & Iminodiacetic acid & 0.14 & $1.05 \mathrm{E}-03$ \\
\hline Molybdenum & 0.016 & $1.69 \mathrm{E}-04$ & Gluconate & 0.082 & $4.17 \mathrm{E}-04$ \\
\hline Nickel & 0.02 & $3.37 \mathrm{E}-04$ & Hydrogen ion & 0.047 & $4.66 \mathrm{E}-02$ \\
\hline
\end{tabular}

The blended eluate composition above was based on a model that did not reflect the planned WTP operation of the Tc eluate evaporator to achieve $80 \%$ of the solubility for the eluate concentrate. Several assumptions were necessary to convert the analytical values into compounds. Boron was assumed to be present as borate anion, chromium as chromate anion, molybdenum as molybdate anion, and silicon as silicate anion. The anions were added as the sodium or potassium salts. The complexants were added as the acid with sufficient sodium hydroxide to convert them to the salt. A test recipe gave a measured density of 1.107 grams/milliliter at $295 \mathrm{~K}$, which agrees well with the OLI model prediction of $1.106 \mathrm{~g} / \mathrm{mL}$ (see Appendix, Table A-1. The recipe used for producing two liters of the blended eluate is listed in Table B- 25. 
WSRC-TR-2001-00203, Rev. 0

SRT-RPP-2001-00051, Rev. 0

TRPT-24590-01-00001

Table B- 25: Blended Eluate Recipe for Two Liters of Feed

\begin{tabular}{|c|c|c|}
\hline Compound & Formula & Mass, grams \\
\hline Water & $\mathrm{H}_{2} \mathrm{O}$ & 800 \\
\hline Boric Acid & $\mathrm{H}_{3} \mathrm{BO}_{3}$ & 1.953 \\
\hline Calcium Nitrate & $\mathrm{Ca}\left(\mathrm{NO}_{3}\right)_{2} \bullet 4 \mathrm{H}_{2} \mathrm{O}$ & 0.006 \\
\hline Cesium Nitrate & $\mathrm{CsNO}_{3}$ & 5.356 \\
\hline Sodium Chloride & $\mathrm{NaCl}$ & 21.385 \\
\hline Sodium Chromate & $\mathrm{Na}_{2} \mathrm{CrO}_{4}$ & 3.17 \\
\hline Ferric Nitrate & $\mathrm{Fe}\left(\mathrm{NO}_{3}\right)_{3} \bullet 9 \mathrm{H}_{2} \mathrm{O}$ & 0.063 \\
\hline Lead Nitrate & $\mathrm{Pb}\left(\mathrm{NO}_{3}\right)_{2}$ & 0.177 \\
\hline Nickel Nitrate & $\mathrm{Ni}\left(\mathrm{NO}_{3}\right)_{2} \bullet 6 \mathrm{H}_{2} \mathrm{O}$ & 0.196 \\
\hline Sodium Nitrite & $\mathrm{NaNO}_{2}$ & 32.783 \\
\hline Potassium Molybdate & $\mathrm{K}_{2} \mathrm{MoO}_{4}$ & 0.08 \\
\hline Potassium Nitrate & $\mathrm{KNO}_{3}$ & 7.616 \\
\hline $\begin{array}{l}\text { Disodium } \\
\text { ethylenediaminetetraacetate }\end{array}$ & $\mathrm{Na}_{2} \mathrm{C}_{10} \mathrm{H}_{14} \mathrm{~N}_{2} \mathrm{O}_{8} \bullet 2 \mathrm{H}_{2} \mathrm{O}$ & 0.514 \\
\hline Sodium Oxalate & $\mathrm{Na}_{2} \mathrm{C}_{2} \mathrm{O}_{4}$ & 13.343 \\
\hline Sodium Gluconate & $\mathrm{HOCH}_{2}[\mathrm{CH}(\mathrm{OH})]_{4} \mathrm{CO}_{2} \mathrm{Na}$ & 0.182 \\
\hline Glycolic Acid & $\mathrm{HOCH}_{2} \mathrm{CO}_{2} \mathrm{H}, 70 \mathrm{wt} \%$ & 1.267 \\
\hline Citric Acid & $\mathrm{HOC}\left(\mathrm{CO}_{2} \mathrm{H}\right)\left(\mathrm{CH}_{2} \mathrm{CO}_{2} \mathrm{H}\right)_{2}$ & 0.479 \\
\hline Nitrilotriacetic Acid & $\mathrm{N}\left(\mathrm{CH}_{2} \mathrm{CO}_{2} \mathrm{H}\right)_{3}$ & 0.026 \\
\hline Iminodiacetic Acid & $\mathrm{HN}\left(\mathrm{CH}_{2} \mathrm{CO}_{2} \mathrm{H}\right)_{2}$ & 0.28 \\
\hline Sodium Metasilicate & $\mathrm{Na}_{2} \mathrm{SiO}_{3} \bullet 9 \mathrm{H}_{2} \mathrm{O}$ & 2.477 \\
\hline Sodium Sulfate & $\mathrm{Na}_{2} \mathrm{SO}_{4}$ & 32.511 \\
\hline Sodium Hydrogen Phosphate & $\mathrm{Na}_{2} \mathrm{HPO}_{4} \bullet 12 \mathrm{H}_{2} \mathrm{O}$ & 2.593 \\
\hline Sodium Dihydrogen Phosphate & $\mathrm{NaH}_{2} \mathrm{PO}_{4} \bullet \mathrm{H}_{2} \mathrm{O}$ & 0.044 \\
\hline Sodium Hydroxide & $\mathrm{NaOH}$ & 0.026 \\
\hline Sodium Carbonate & $\mathrm{Na}_{2} \mathrm{CO}_{3}$ & 3.744 \\
\hline Sodium Bicarbonate & $\mathrm{NaHCO}_{3}$ & 21.603 \\
\hline Sodium Nitrate & $\mathrm{NaNO}_{3}$ & 185.75 \\
\hline Sodium Hydroxide & $\mathrm{NaOH}$ & 4.06 \\
\hline Water & $\mathrm{H}_{2} \mathrm{O}$ & 1073.0 \\
\hline
\end{tabular}

The measured density of the two-liter batch was also $1.107 \mathrm{~g} / \mathrm{mL}$ at $295 \mathrm{~K}$. The $\mathrm{pH}$ of the two liter batch was 8.9. The eluate basis for blending with the sludge and the Sr/TRU precipitate is listed in Table B- 26 expressed as waste oxides. 
WSRC-TR-2001-00203, Rev. 0

Table B- 26: Blended Eluate Basis for Blending Streams

\begin{tabular}{|c|c|c|c|}
\hline Component & Molar & Oxide & Oxide, g/L \\
\hline Aluminum & $7.13 \mathrm{E}-10$ & $\mathrm{Al}_{2} \mathrm{O}_{3}$ & 0.00 \\
\hline Barium & $5.48 \mathrm{E}-07$ & $\mathrm{BaO}$ & 0.00 \\
\hline Boron & $1.58 \mathrm{E}-02$ & $\mathrm{~B}_{2} \mathrm{O}_{3}$ & 0.55 \\
\hline Cadmium & 0 & $\mathrm{CdO}$ & 0.00 \\
\hline Calcium & $1.32 \mathrm{E}-05$ & $\mathrm{CaO}$ & 0.00 \\
\hline Cerium & 0 & $\mathrm{CeO}_{2}$ & 0.00 \\
\hline Cesium & $1.37 \mathrm{E}-02$ & $\mathrm{Cs}_{2} \mathrm{O}$ & 1.94 \\
\hline Chromium & $9.79 \mathrm{E}-03$ & $\mathrm{Cr}_{2} \mathrm{O}_{3}$ & 0.74 \\
\hline Cobalt & 0 & $\mathrm{CoO}$ & 0.00 \\
\hline Copper & 0 & $\mathrm{CuO}$ & 0.00 \\
\hline Iron & $7.79 \mathrm{E}-05$ & $\mathrm{Fe}_{2} \mathrm{O}_{3}$ & 0.01 \\
\hline Lanthanum & 0 & $\mathrm{La}_{2} \mathrm{O}_{3}$ & 0.00 \\
\hline Lead & $2.67 \mathrm{E}-04$ & $\mathrm{PbO}$ & 0.06 \\
\hline Magnesium & 0 & $\mathrm{MgO}$ & 0.00 \\
\hline Manganese & 0 & $\mathrm{MnO}_{2}$ & 0.00 \\
\hline Molybdenum & $1.69 \mathrm{E}-04$ & $\mathrm{MoO}_{3}$ & 0.01 \\
\hline Neodymium & 0 & $\mathrm{Nd}_{2} \mathrm{O}_{3}$ & 0.00 \\
\hline Nickel & $3.37 \mathrm{E}-04$ & $\mathrm{NiO}$ & 0.03 \\
\hline Potassium & $3.80 \mathrm{E}-02$ & $\mathrm{~K}_{2} \mathrm{O}$ & 1.79 \\
\hline Phosphorus & $5.00 \mathrm{E}-03$ & $\mathrm{P}_{2} \mathrm{O}_{5}$ & 0.35 \\
\hline Selenium & 0 & $\mathrm{SeO}_{2}$ & 0.00 \\
\hline Silicon & $4.36 \mathrm{E}-03$ & $\mathrm{SiO}_{2}$ & 0.26 \\
\hline Silver & 0 & $\mathrm{Ag}_{2} \mathrm{O}$ & 0.00 \\
\hline Sodium & $2.04 \mathrm{E}-00$ & $\mathrm{Na}_{2} \mathrm{O}$ & 63.29 \\
\hline Tin & 0 & $\mathrm{SnO}_{2}$ & 0.00 \\
\hline Uranium & 0.0072106 & $\mathrm{UO}_{2}$ & 1.95 \\
\hline Zinc & 0 & $\mathrm{ZnO}$ & 0.00 \\
\hline Zirconium & 0 & $\mathrm{ZrO}_{2}$ & 0.00 \\
\hline Total & & & 70.97 \\
\hline
\end{tabular}

The simulant does not contain the uranium shown in Table B- 26.

\section{Blending Basis for the AZ-101 Test Mixtures}

The Waste Treatment Plant of the River Protection Project will blend Envelope D sludges with Sr/TRU precipitate and the concentrated, blended ion exchange eluates to produce a glass waste form with a specified composition. The waste loading in the glass is therefore based on sludge, strontium and cesium loadings. The composition for the AZ-101 simulated sludge, the Sr/TRU precipitate and the blended eluate basis was provided to the Vitreous State Laboratory (VSL) at Catholic University, Washington, D.C. for computation of the necessary blending ratio. The essential factors in developing the blending ratio are the $\mathrm{Al}, \mathrm{Fe}$ and $\mathrm{Zr}$ in the sludge, the strontium in the Sr/TRU precipitate and the total cesium in the blended eluate. The blending ratio is derived from the information in Table B- 27 provided by VSL. The cesium blend basis is based on assuming that ${ }^{137} \mathrm{Cs}$ is $25 \%$ of the total cesium while the current design basis for AZ101 and $A Z-102$ is $30 \%$. 
WSRC-TR-2001-00203, Rev. 0

SRT-RPP-2001-00051, Rev. 0

TRPT-24590-01-00001

Table B- 27: Vitreous State Laboratory (VSL) Blending Basis for AZ-101

\begin{tabular}{|c|c|c|c|c|c|c|c|c|c|c|c|c|}
\hline & & \multirow{2}{*}{\multicolumn{2}{|c|}{$\begin{array}{c}\text { SRTC } \\
\text { AZ-101 Simulant }\end{array}$}} & \multicolumn{2}{|c|}{ AN107 TRU/Sr } & \multirow{2}{*}{\multicolumn{3}{|c|}{$\begin{array}{c}\text { SRTC AZ-102 } \\
\text { Eluate }\end{array}$}} & \multirow{2}{*}{\multicolumn{4}{|c|}{$\begin{array}{c}\text { Oxide Contribution to } \\
3250 \mathrm{~kg} \text { of Glass }\end{array}$}} \\
\hline & & & & & & & & & & & & \\
\hline & & Oxide & Oxide & Oxide & Oxide & & Oxide & Oxide & & $\begin{array}{c}\text { AZ101 } \\
\text { Simula } \\
\text { nt }\end{array}$ & TRU/SR & $\begin{array}{l}\text { AZ102 } \\
\text { Eluate }\end{array}$ \\
\hline & & (g/g solid) & $(w t \%)$ & $(\mathrm{mg} / \mathrm{L})$ & (wt\%) & & g/L & $(w t \%)$ & & (kg) & (kg) & (kg) \\
\hline & $\mathrm{Ag} 2 \mathrm{O}$ & $2.40 \mathrm{E}-03$ & $0.26 \%$ & & & & 0.00000 & $0.00 \%$ & & 2.54 & & 0.000 \\
\hline & $\mathrm{Al} 2 \mathrm{O} 3$ & $1.09 \mathrm{E}-01$ & $11.77 \%$ & 445.85 & $0.37 \%$ & & 0.00000 & $0.00 \%$ & & 115.64 & 0.504 & 0.000 \\
\hline & $\mathrm{B} 2 \mathrm{O} 3$ & $2.59 \mathrm{E}-03$ & $0.28 \%$ & 67.61 & $0.06 \%$ & & 0.54972 & $0.77 \%$ & & 2.73 & 0.076 & 0.006 \\
\hline & $\mathrm{BaO}$ & $2.36 \mathrm{E}-03$ & $0.25 \%$ & 11.16 & $0.01 \%$ & & 0.00008 & $0.00 \%$ & & 2.50 & 0.013 & 0.000 \\
\hline & $\mathrm{CaO}$ & $1.26 \mathrm{E}-02$ & $1.36 \%$ & 2182.52 & $1.79 \%$ & & 0.00074 & $0.00 \%$ & & 13.36 & 2.468 & 0.000 \\
\hline & $\mathrm{CdO}$ & $2.55 \mathrm{E}-02$ & $2.74 \%$ & & & & 0.00000 & $0.00 \%$ & & 26.92 & 0.000 & 0.000 \\
\hline & $\mathrm{CeO} 2$ & $3.30 \mathrm{E}-03$ & $0.35 \%$ & & & & 0.00000 & $0.00 \%$ & & 3.49 & 0.000 & 0.000 \\
\hline & $\mathrm{CoO}$ & $3.64 \mathrm{E}-03$ & $0.39 \%$ & 6.36 & $0.01 \%$ & & 0.00000 & $0.00 \%$ & & 3.84 & 0.007 & 0.000 \\
\hline & $\mathrm{Cr} 2 \mathrm{O} 3$ & $3.27 \mathrm{E}-03$ & $0.35 \%$ & 128.60 & $0.11 \%$ & & 0.74376 & $1.05 \%$ & & 3.46 & 0.145 & 0.008 \\
\hline & $\mathrm{Cs} 2 \mathrm{O}$ & & & & & & 1.93574 & $2.73 \%$ & & & 0.000 & 0.021 \\
\hline & $\mathrm{CuO}$ & $1.23 \mathrm{E}-03$ & $0.13 \%$ & 37.55 & $0.03 \%$ & & 0.00000 & $0.00 \%$ & & 1.29 & 0.042 & 0.000 \\
\hline & Dy2O3 & $1.76 \mathrm{E}-04$ & $0.02 \%$ & & & & & & & 0.19 & 0.000 & 0.000 \\
\hline & $\mathrm{Fe} 2 \mathrm{O} 3$ & $4.07 \mathrm{E}-01$ & $43.83 \%$ & 11222.23 & $9.21 \%$ & & 0.00622 & $0.01 \%$ & & 430.71 & 12.690 & 0.000 \\
\hline & $\mathrm{K} 2 \mathrm{O}$ & $7.67 \mathrm{E}-03$ & $0.82 \%$ & & & & 1.78992 & $2.52 \%$ & & 8.10 & 0.000 & 0.019 \\
\hline & La2O3 & $1.35 \mathrm{E}-02$ & $1.45 \%$ & 248.62 & $0.20 \%$ & & 0.00000 & $0.00 \%$ & & 14.28 & 0.281 & 0.000 \\
\hline & $\mathrm{MgO}$ & $2.67 \mathrm{E}-03$ & $0.29 \%$ & 190.68 & $0.16 \%$ & & 0.00000 & $0.00 \%$ & & 2.82 & 0.216 & 0.000 \\
\hline & $\mathrm{MnO}$ & $8.56 \mathrm{E}-03$ & $0.92 \%$ & 28536.11 & $23.42 \%$ & & 0.00000 & $0.00 \%$ & & 9.05 & 32.269 & 0.000 \\
\hline & $\mathrm{MoO} 3$ & $2.17 \mathrm{E}-04$ & $0.02 \%$ & 15.00 & $0.01 \%$ & & 0.02429 & $0.03 \%$ & & 0.23 & 0.017 & 0.000 \\
\hline & $\mathrm{Na} 2 \mathrm{O}$ & $1.12 \mathrm{E}-01$ & $12.03 \%$ & 13040.56 & $10.70 \%$ & & 63.28656 & $89.15 \%$ & & 118.22 & 14.747 & 0.673 \\
\hline & $\mathrm{Nd} 2 \mathrm{O} 3$ & $8.98 \mathrm{E}-03$ & $0.97 \%$ & & & & 0.00000 & $0.00 \%$ & & 9.49 & 0.000 & 0.000 \\
\hline & $\mathrm{NiO}$ & $2.23 \mathrm{E}-02$ & $2.40 \%$ & 50.90 & $0.04 \%$ & & 0.02519 & $0.04 \%$ & & 23.61 & 0.058 & 0.000 \\
\hline & $\mathrm{P} 2 \mathrm{O} 5$ & & & & & & 0.35478 & $0.50 \%$ & & & 0.000 & 0.004 \\
\hline & $\mathrm{PbO}$ & $3.51 \mathrm{E}-03$ & $0.38 \%$ & 64.63 & $0.05 \%$ & & 0.05953 & $0.08 \%$ & & 3.71 & 0.073 & 0.001 \\
\hline & $\mathrm{Re} 2 \mathrm{O} 7$ & $2.06 \mathrm{E}-04$ & $0.02 \%$ & & & & & & & 0.22 & 0.000 & 0.000 \\
\hline & Rh2O3 & $1.23 \mathrm{E}-03$ & $0.13 \%$ & & & & & & & 1.30 & 0.000 & 0.000 \\
\hline & $\mathrm{RuO} 2$ & $2.19 \mathrm{E}-03$ & $0.24 \%$ & & & & & & & 2.31 & 0.000 & 0.000 \\
\hline & $\mathrm{SiO} 2$ & $3.01 \mathrm{E}-02$ & $3.24 \%$ & 254.53 & $0.21 \%$ & & 0.26168 & $0.37 \%$ & & 31.84 & 0.288 & 0.003 \\
\hline & $\mathrm{SnO}$ & & & 29.50 & $0.02 \%$ & & 0.00000 & $0.00 \%$ & & & 0.033 & 0.000 \\
\hline & $\mathrm{SrO}$ & $1.78 \mathrm{E}-03$ & $0.19 \%$ & 64534.65 & $52.96 \%$ & & & & & 1.88 & 72.977 & 0.000 \\
\hline & $\mathrm{TiO} 2$ & $4.56 \mathrm{E}-04$ & $0.05 \%$ & 23.31 & $0.02 \%$ & & & & & 0.48 & 0.026 & 0.000 \\
\hline & UO2 & & & & & & 1.94708 & $2.74 \%$ & & & 0.000 & 0.021 \\
\hline & V2O5 & & & 23.21 & $0.02 \%$ & & & & & & 0.026 & 0.000 \\
\hline & $\mathrm{ZnO}$ & $1.08 \mathrm{E}-03$ & $0.12 \%$ & 110.77 & $0.09 \%$ & & 0.00000 & $0.00 \%$ & & 1.14 & 0.125 & 0.000 \\
\hline & $\mathrm{ZrO} 2$ & $1.29 \mathrm{E}-01$ & $13.86 \%$ & 272.84 & $0.22 \%$ & & 0.00000 & $0.00 \%$ & & 136.16 & 0.309 & 0.000 \\
\hline & $\mathrm{F}$ & $1.39 \mathrm{E}-03$ & $0.15 \%$ & 7.70 & $0.01 \%$ & & & & & 1.47 & 0.009 & 0.000 \\
\hline & $\mathrm{Cl}$ & $2.55 \mathrm{E}-04$ & $0.03 \%$ & 61.00 & $0.05 \%$ & & & & & 0.27 & 0.069 & 0.000 \\
\hline & $\mathrm{SO} 3$ & $7.57 \mathrm{E}-03$ & $0.81 \%$ & 178.33 & $0.15 \%$ & & & & & 8.00 & 0.202 & 0.000 \\
\hline & $\mathrm{P} 2 \mathrm{O} 5$ & $1.25 \mathrm{E}-03$ & $0.13 \%$ & 105.33 & $0.09 \%$ & & & & & 1.32 & 0.119 & 0.000 \\
\hline & TOTAL & 0.9295 & $100.00 \%$ & 121849.6 & $100.00 \%$ & & 70.9853 & $100.00 \%$ & & 982.56 & 137.79 & 0.76 \\
\hline & & & & \multicolumn{2}{|c|}{$6010 \mathrm{~kg}$ of $\mathrm{Sr}$ to be added to } & & \multicolumn{3}{|c|}{ Cs 137 is $25 \%$ of all Cs as in } & & & \\
\hline & $\mathrm{Al}+\mathrm{Fe}+\mathrm{Zr}$ & & $69.46 \%$ & \multicolumn{2}{|c|}{ a projected $316509 \mathrm{~kg}$ of AZ101 } & & \multicolumn{3}{|c|}{ earlier simulant, total Cs2O to } & & & \\
\hline & Glass/Waste & & 3.30766955 & \multicolumn{2}{|c|}{ Glass (Ref: E. Slaathaug) } & & \multicolumn{3}{|c|}{ be blended is still $0.0206 \mathrm{~kg}$} & & & \\
\hline & \multicolumn{2}{|c|}{ Calculated Loading } & 0.30232766 & & & & & & & & & \\
\hline To make & 3250 & Oxide & 982.56 & $\mathrm{SrO}$ & 72.98 & $\mathrm{~kg}$ & $\mathrm{Cs} 2 \mathrm{O}$ & 0.0206 & $\mathrm{~kg}$ & & & \\
\hline \multicolumn{2}{|c|}{ kg of glass, need (kg) } & Waste & 1057.04 & Sr/TRU product & 1130.82 & $\mathrm{~L}$ & Eluate & 10.64 & $\mathrm{~L}$ & & & \\
\hline & & & & & & & Wt Eluate & 11.77 & $\mathrm{~kg}$ & & & \\
\hline
\end{tabular}

The VSL blending ratio is based upon producing 3250 kilograms of glass. The mass of AZ-101 waste to use is based upon the sum of the mass of aluminum oxide, iron oxide and zirconium oxide making up 21 percent of the glass. For the composition listed in Table B- 27, the amount 
WSRC-TR-2001-00203, Rev. 0

SRT-RPP-2001-00051, Rev. 0

TRPT-24590-01-00001

of $\mathrm{Al}+\mathrm{Fe}+\mathrm{Zr}$ should be $682.5 \mathrm{~kg}$ and the amount of waste oxides should be $682.5 / 0.6946$ or $982.6 \mathrm{~kg}$. After converting from waste oxides to total solids, the amount required for $3250 \mathrm{~kg}$ of glass from Table B-27 is $1057.04 \mathrm{~kg}$ of AZ-101 simulated sludge. Applying the same logic to the actually produced and measured AZ-101 simulated sludge gave the following:

$\mathrm{Al}+\mathrm{Fe}+\mathrm{Zr}$ Oxides

AZ-101 Sludge Oxide Required

AZ-101 Sludge Oxide Calcine factor

AZ-101 Sludge Solids Required
$70.77 \%$ (based on early analytical results)

$(3250 * 0.21) / 0.7077=964.4 \mathrm{~kg}$

0.805

$964.4 / 0.805=1198 \mathrm{~kg}$.

The amount of Sr/TRU precipitate to add to the VSL formulated AZ-101 glass was based upon placing $6010 \mathrm{~kg}$ of strontium in $316509 \mathrm{~kg}$ of glass. For the AZ-101 glass, this requires that $72.98 \mathrm{~kg}$ of $\mathrm{SrO}$ be used for $3250 \mathrm{~kg}$ of glass. Applying the $72.98 \mathrm{~kg}$ of $\mathrm{SrO}$ to the information in Table B- 23 required that $72.98 / 0.513=142.26 \mathrm{~kg}$ of Sr/TRU waste oxides were required for $3250 \mathrm{~kg}$ of glass. Applying the measured calcine factor of 0.747 for the Sr/TRU precipitate, produced for this study, yielded $190.52 \mathrm{~kg}$ of precipitate solids for $3250 \mathrm{~kg}$ of glass.

The final essential blending ratio was for the amount of blended eluate to add to produce $3250 \mathrm{~kg}$ of glass. The amount of blended eluate was based upon 10.64 liters of the blended eluate for $3250 \mathrm{~kg}$ of glass. Applying the measured density of $1.107 \mathrm{~g} / \mathrm{mL}$ to the volume yielded $11.78 \mathrm{~kg}$ of blended eluate for $3250 \mathrm{~kg}$ of glass. Table B-28 summarizes the values used to create the waste blends for AZ-101 glass for rheology testing.

Table B- 28: AZ-101 Blending Ratios

\begin{tabular}{|l|c|}
\hline Waste Stream & Weight, kg \\
\hline AZ-101 Simulated Sludge Solids & 1198 \\
\hline AN-107 Sr/TRU Precipitate Solids & 190.52 \\
\hline AZ-102 Blended Eluate Simulant & 11.78 \\
\hline
\end{tabular}

\section{Test 1.3}

The goal of Test 1.3 was to mix $20 \mathrm{wt} \%$ insoluble solids AZ-101 sludge with $20 \mathrm{wt} \%$ insoluble solids Sr/TRU precipitate and blended eluate and determine the rheology of the mixture. The volume of the mixture needed was at least $750 \mathrm{~mL}$. The following steps were used to make the test mixture:

1. Mass of $20 \mathrm{wt} \%$ insoluble solids AZ-101 Sludge simulant to use: $750 *$ density $(1.176 \mathrm{~g} / \mathrm{mL})$ $=882$ grams. Actually used: 882.09 grams.

2. Mass of Sludge Solids is: $882 \mathrm{~g} * \mathrm{Wt} \%$ Total Solids $(20.77 \%)=183.19$ grams.

3. The amount of Sr/TRU solids required for 183.19 grams of sludge solids is: $183.19 \mathrm{~g} * \mathrm{Sr} / \mathrm{TRU}$ Basis (190.52)/AZ-101 Sludge Basis $(1198)=29.13$ grams.

4. The amount of $20 \mathrm{wt} \%$ insoluble solids Sr/TRU precipitate to add is: 29.13/wt \% total Solids Sr/TRU (22.52 \%) = 129.37 grams. Actually used: 129.39 grams. 
5. The amount of blended eluate to add:

$183.19 \mathrm{~g} *$ Basis for Eluate (11.78)/Basis for AZ-101 (1198) = 1.80 grams of eluate.

Actually used: 1.8 grams.

The physical properties for the Test 1.3 blend are listed in Table 13. Mixing a 20 weight $\%$ solids slurry with another $\sim 20$ weight $\%$ solids did not result in diluting the measured solids for the mixture. A sample of the test mixture was submitted for chemical analysis. The results expressed on a weight \% oxide basis are shown in Table B-29. The agreement between the found and the target is reasonable, since the target is based upon the originally planned compositions for the waste streams.

Table B- 29: Composition of Test 1.3 Compared to Target

\begin{tabular}{|c|c|c|c|c|c|}
\hline \multicolumn{2}{c}{ Oxide } & Wt \% & \multicolumn{2}{c|}{ Target Wt \% } & \multicolumn{2}{c|}{ Oxide } & Wt \% & Target Wt \% \\
\hline $\mathrm{Al}_{2} \mathrm{O}_{3}$ & 11.87 & 10.36 & $\mathrm{P}_{2} \mathrm{O}_{5}$ & 2.75 & 0.13 \\
\hline $\mathrm{BaO}$ & 0.21 & 0.22 & $\mathrm{PbO}$ & 0.48 & 0.34 \\
\hline $\mathrm{CaO}$ & 1.17 & 1.41 & $\mathrm{SiO}_{2}$ & 3.37 & 2.87 \\
\hline $\mathrm{CdO}$ & 2.61 & 2.4 & $\mathrm{SrO}$ & 6.17 & 6.68 \\
\hline $\mathrm{CoO}$ & 0.38 & 0.34 & $\mathrm{TiO}_{2}$ & 0.05 & 0.05 \\
\hline $\mathrm{Cr} \mathrm{O}_{3}$ & 0.38 & 0.32 & $\mathrm{ZnO}$ & 0.14 & 0.11 \\
\hline $\mathrm{CuO}$ & 0.23 & 0.12 & $\mathrm{ZrO}$ & 11.7 & 12.17 \\
\hline $\mathrm{Fe}_{2} \mathrm{O}_{3}$ & 44.01 & 39.55 & $\mathrm{La}_{2} \mathrm{O}_{3}$ & 1.37 & 1.3 \\
\hline $\mathrm{MgO}$ & 0.1 & 0.27 & $\mathrm{~K}_{2} \mathrm{O}$ & 0.71 & 0.72 \\
\hline $\mathrm{MnO}$ & 3.49 & 3.69 & $\mathrm{Ag}_{2} \mathrm{O}$ & 0.23 & 0.23 \\
\hline $\mathrm{MoO}$ & 0.03 & 0.02 & $\mathrm{CeO}_{2}$ & 0.36 & 0.31 \\
\hline $\mathrm{Na}_{2} \mathrm{O}$ & 7.19 & 11.92 & $\mathrm{Nd}_{2} \mathrm{O}_{3}$ & 1.01 & 0.85 \\
\hline
\end{tabular}

\section{Test 1.4}

The goal of Test 1.4 was to mix 15 wt \% insoluble solids AZ-101 sludge with 15 wt \% insoluble solids Sr/TRU precipitate and blended eluate and determine the rheology of the mixture. The volume of the mixture needed was at least $500 \mathrm{~mL}$. The following steps were used to make the test mixture:

1. Mass of $15 \mathrm{wt} \%$ insoluble solids AZ-101 Sludge simulant to use: $500 *$ density $(1.125 \mathrm{~g} / \mathrm{mL})$ $=562.5$ grams. Actually used: 562.53 grams.

2. Mass of Sludge Solids is: $562.5^{*} \mathrm{Wt} \%$ Total Solids $(16.26 \%)=91.46$ grams.

3. The amount of Sr/TRU solids required for 91.46 grams of sludge solids is: 91.46 $\mathrm{g} * \mathrm{Sr} / \mathrm{TRU}$ Basis (190.52)/AZ-101 Sludge Basis (1198) = 14.55 grams.

4. The amount of $15 \mathrm{wt} \%$ insoluble solids Sr/TRU precipitate to add is: $14.55 \mathrm{~g} / \mathrm{wt} \%$ total Solids Sr/TRU $(17.65 \%)=82.44$ grams. Actually used: 82.47 grams.

5. The amount of blended eluate to add:

91.46 $\mathrm{g} *$ Basis for Eluate (11.78)/Basis for AZ-101 (1198) = 0.9 grams of eluate. Actually used: 0.9 grams.

The physical properties for the Test 1.4 blend are listed in Table 13. Mixing a $\sim 15$ wt $\%$ solids slurry with another $\sim 15 \mathrm{wt} \%$ solids did not result in diluting the measured solids for the mixture. 
WSRC-TR-2001-00203, Rev. 0

A sample of the test mixture was submitted for chemical analysis. The results expressed on a wt percent oxide basis are shown in Table B- 30. The agreement between the found and the target is reasonable, since the target is based upon the originally planned compositions for the waste streams.

Table B- 30: Composition of Test 1.4 Compared to Target

\begin{tabular}{|c|c|c|c|c|c|}
\hline Oxide & \multicolumn{2}{c}{ Wt \% } & \multicolumn{2}{c|}{ Target Wt \% } & \multicolumn{2}{c|}{ Oxide } & Wt \% & Target Wt \% \\
\hline $\mathrm{Al}_{2} \mathrm{O}_{3}$ & 11.16 & 10.36 & $\mathrm{P}_{2} \mathrm{O}_{5}$ & 2.56 & 0.13 \\
\hline $\mathrm{B}_{2} \mathrm{O}_{3}$ & 0.24 & 0.25 & $\mathrm{PbO}$ & 0.47 & 0.34 \\
\hline $\mathrm{BaO}$ & 0.21 & 0.22 & $\mathrm{SiO}_{2}$ & 3.20 & 2.87 \\
\hline $\mathrm{CaO}$ & 1.23 & 1.41 & $\mathrm{SrO}$ & 6.20 & 6.68 \\
\hline $\mathrm{CdO}$ & 2.53 & 2.4 & $\mathrm{TiO}_{2}$ & 0.05 & 0.05 \\
\hline $\mathrm{CoO}$ & 0.37 & 0.34 & $\mathrm{ZnO}$ & 0.13 & 0.11 \\
\hline $\mathrm{Cr} \mathrm{O}_{3}$ & 0.37 & 0.32 & $\mathrm{ZrO}_{2}$ & 9.45 & 12.17 \\
\hline $\mathrm{CuO}$ & 0.17 & 0.12 & $\mathrm{La}_{2} \mathrm{O}_{3}$ & 1.36 & 1.3 \\
\hline $\mathrm{Fe} \mathrm{O}_{3}$ & 42.56 & 39.55 & $\mathrm{~K}_{2} \mathrm{O}$ & 0.83 & 0.72 \\
\hline $\mathrm{MgO}$ & 0.1 & 0.27 & $\mathrm{Re}_{2} \mathrm{O}_{7}$ & 0.05 & 0.02 \\
\hline $\mathrm{MnO}$ & 3.30 & 3.69 & $\mathrm{SO}_{3}$ & 0.54 & 0.73 \\
\hline $\mathrm{MoO}$ & 0.02 & 0.02 & $\mathrm{Ag}_{2} \mathrm{O}$ & 0.28 & 0.23 \\
\hline $\mathrm{Na} \mathrm{O}_{2} \mathrm{O}$ & 9.03 & 11.92 & $\mathrm{CeO}_{2}$ & 0.37 & 0.31 \\
\hline $\mathrm{NiO}$ & 2.27 & 2.11 & $\mathrm{Nd}_{2} \mathrm{O}_{3}$ & 0.95 & 0.85 \\
\hline
\end{tabular}

Additional tests planned for Test 1.4 required determining the amount of acid needed to shift the test mixture's pH from 10.14 to values near 9, 7 and 5. A 2.23 gram sample of the mixture was added to $60 \mathrm{~mL}$ of deionized water and titrated with 0.1013 molar hydrochloric acid until the $\mathrm{pH}$ was 5. Figure B - 4 shows the resulting titration curve as a function of the moles of acid added/kilogram of sludge. The shape of the titration curve is controlled by the basic species being titrated. For the blended mixture in Test 1.4, the basic species include hydroxide, phosphate and carbonate with the major species being carbonate. The fitted equation shown in Figure B - 4 was empirically obtained using TableCurve ${ }^{\mathrm{TM}} 2 \mathrm{D}$ software and should not be used to extrapolate beyond the fitted region $(\mathrm{pH} 11$ to $\mathrm{pH}$ 5). Based upon the titration curve, the amount of a monoprotic acid to reach $\mathrm{pH} 9$ was 0.0695 moles per kilogram of the blended mixture. To reach $\mathrm{pH} 7$ the amount of acid would be 0.156 moles per kilogram of slurry and for $\mathrm{pH} 5$ the amount is 0.459 moles per kilogram of slurry. The adjustment of the $\mathrm{pH}$ of a portion of Test 1.4 with 10.34 molar nitric acid $(50 \mathrm{wt} \%)$ consisted of the following steps:

1. Add 230 grams of Test 1.4 mixture to a tared, $250 \mathrm{~mL}$ bottle and record the weight. Actually used net weight was 229.54 grams. Tare weight was 28.35 grams.

2. Using a calibrated digital pipette add $1.54 \mathrm{~mL}$ of 10.34 molar nitric acid. Actually added $1.54 \mathrm{~mL}$.

3. Mix thoroughly, measure, and record $\mathrm{pH}$. Measured $\mathrm{pH}$ was 8.16.

4. Transfer about 30 grams of the $\mathrm{pH}$-adjusted mixture to $30 \mathrm{~mL}$ container labeled as Test $\mathbf{1 . 4}$ pH 9 Adjusted, weigh and record the weight. Amount of slurry removed was 20.01 grams due to the thick, sticky properties of the slurry. This sample was used for rheology measurements.

5. Obtain mass of $\mathrm{pH}$ adjusted $250 \mathrm{~mL}$ bottle and calculate the amount of acid necessary to reduce $\mathrm{pH}$ to 7 . Actual gross mass was 259.72 grams. Tare weight was 28.35 grams. 
6. Using a calibrated digital pipette add $1.76 \mathrm{~mL}$ of 10.34 molar nitric acid. Actually added $1.76 \mathrm{~mL}$.

7. Mix thoroughly, measure, and record $\mathrm{pH}$. Measured $\mathrm{pH}$ was 7.01.

8. Transfer about 30 grams of the $\mathrm{pH}$-adjusted mixture to $30 \mathrm{~mL}$ container labeled as Test $\mathbf{1 . 4}$ pH 7 Adjusted, weigh and record the weight. Amount of slurry removed was 17.83 grams due to the thick, sticky properties of the slurry. This sample was used for rheology measurements.

9. Obtain mass of $\mathrm{pH}$ adjusted $250 \mathrm{~mL}$ bottle and calculate the amount of acid necessary to reduce $\mathrm{pH}$ to 5. Actual gross mass was 213.52 grams. Tare Weight was 28.35 grams.

10. Using a calibrated digital pipette add $5.42 \mathrm{~mL}$ of 10.34 molar nitric acid. Actually added $5.42 \mathrm{~mL}$.

11. Mix thoroughly, measure, and record $\mathrm{pH}$. Measured $\mathrm{pH}$ was 5.09.

12. Labeled $250 \mathrm{~mL}$ bottle as Test 1.4 pH 5 Adjusted and used the sample for rheology and chemical analysis.

During the $\mathrm{pH}$ adjustment, gas evolution was observed during the acid addition. The gas produced was probably carbon dioxide due to the conversion of carbonate to bicarbonate and then to carbonic acid $\left(\mathrm{H}_{2} \mathrm{O}+\mathrm{CO}_{2}\right)$. The stability of the adjusted $\mathrm{pH}$ as a function of time was not studied as part of this program. The actual rheology results for the starting and $\mathrm{pH}$-adjusted Test 1.4 mixtures are discussed in the main section of this report. 
Figure B - 4: Test Mix 1.4 Titration Curve

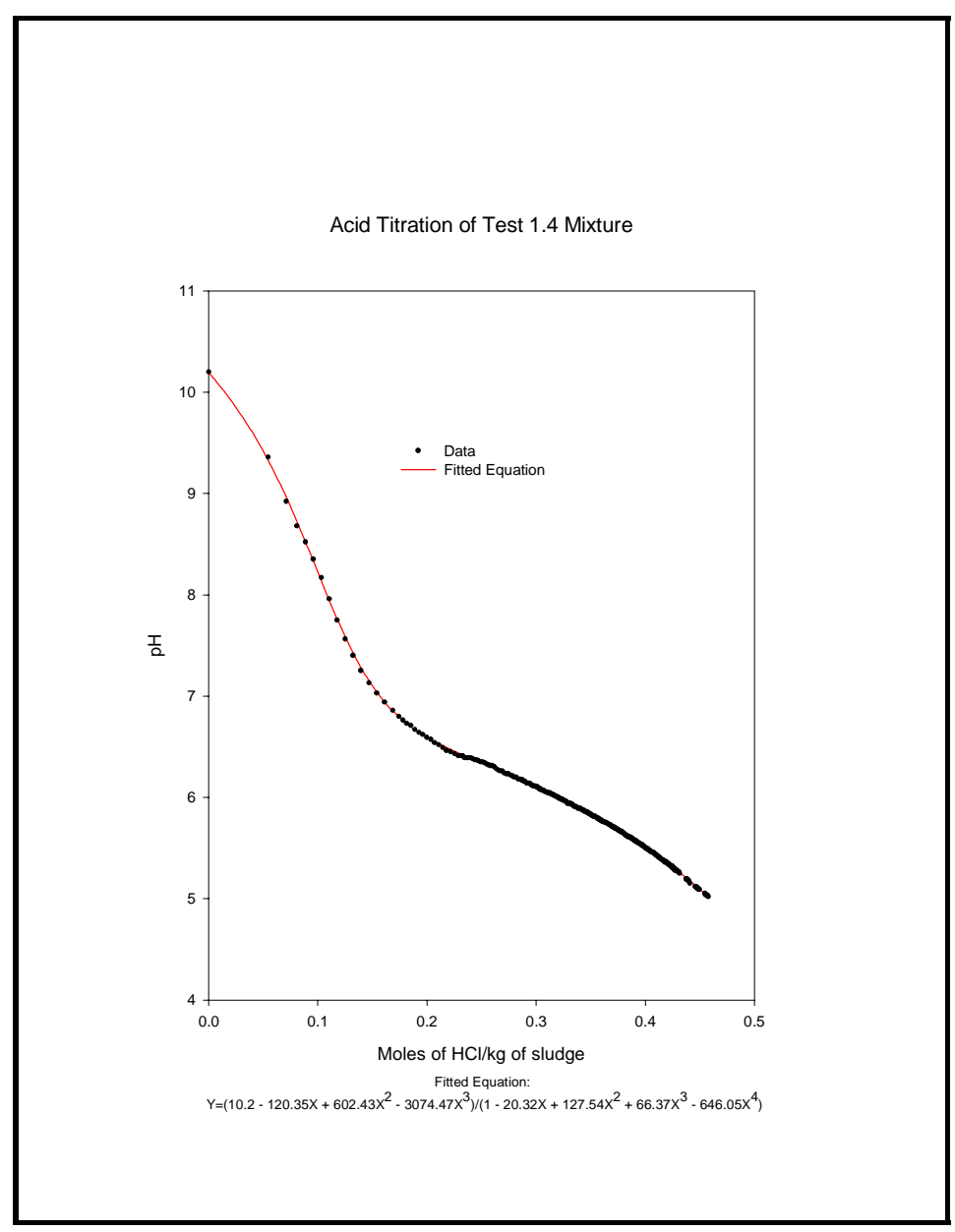

Figure B - 5: Test Mix 1.5 Titration Curve

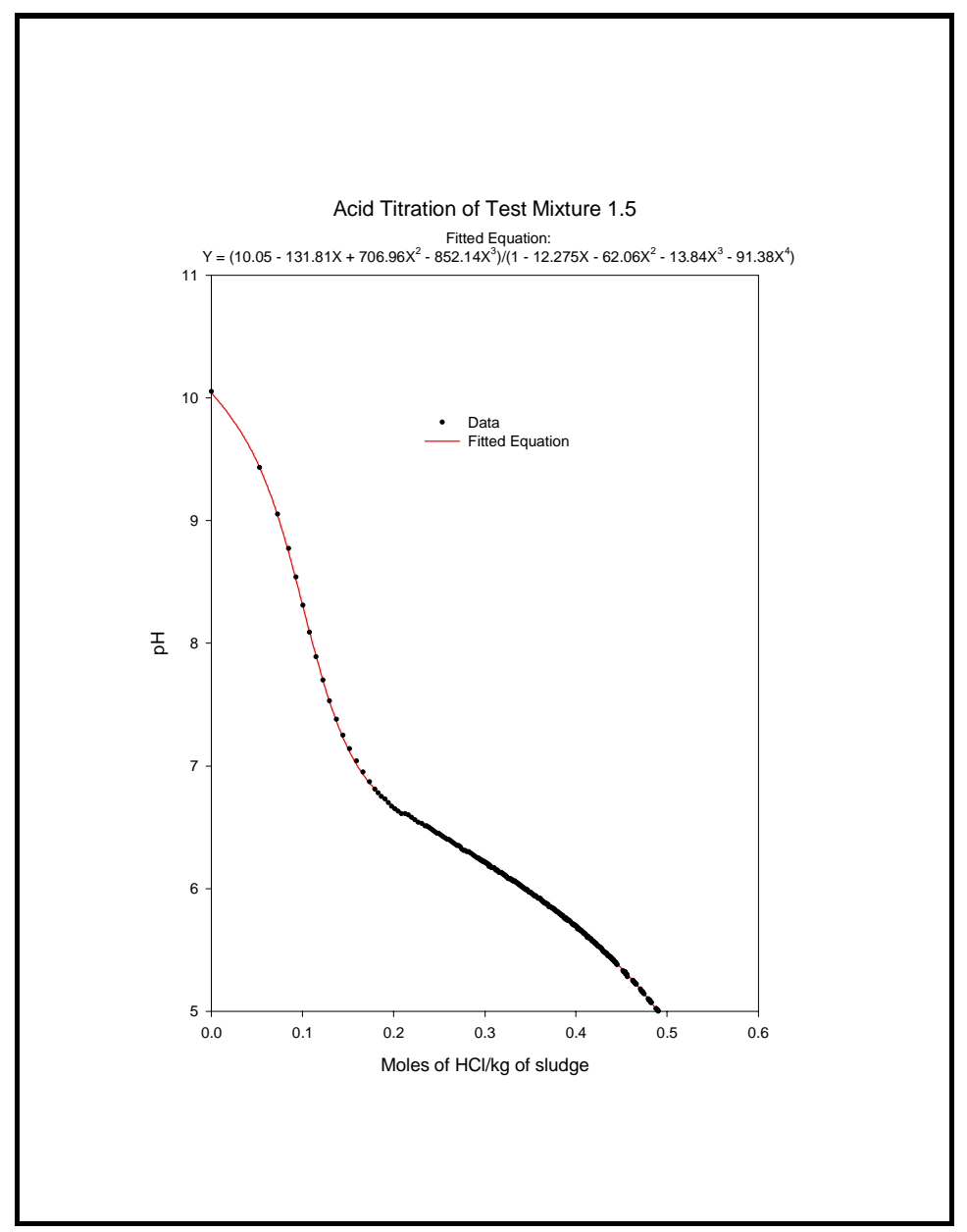




\section{Test 1.5}

The goal of Test 1.5 was to mix 15 wt \% insoluble solids AZ-101 sludge with 25 wt \% insoluble solids Sr/TRU precipitate and blended eluate and determine the rheology of the mixture. The volume of the mixture needed was at least $500 \mathrm{~mL}$. The following steps were used to make the test mixture:

1. Mass of 15 wt $\%$ insoluble solids AZ-101 Sludge simulant to use: $500 \mathrm{~mL}$ *density $(1.125$ $\mathrm{g} / \mathrm{mL})=562.5$ grams. Actually used: 562.52 grams.

2. Mass of Sludge Solids is: $562.5 \mathrm{~g} * \mathrm{Wt} \%$ Total Solids $(16.26 \%)=91.46$ grams.

3. The amount of $\mathrm{Sr} / \mathrm{TRU}$ solids required for 91.46 grams of sludge solids is: $91.46 \mathrm{~g} * \mathrm{Sr} / \mathrm{TRU}$ Basis (190.52 g)/AZ-101 Sludge Basis (1198 g) = 14.55 grams.

4. The amount of $25 \mathrm{wt} \%$ insoluble solids $\mathrm{Sr} / \mathrm{TRU}$ precipitate to add is: $14.55 \mathrm{~g} / \mathrm{wt} \%$ total Solids Sr/TRU $(27.32 \%)=53.24$ grams. Actually used: 53.26 grams.

5. The amount of blended eluate to add:

$91.46 \mathrm{~g} *$ Basis for Eluate (11.78)/Basis for AZ-101 (1198) = 0.9 grams of eluate. Actually used: 0.9 grams.

The physical properties for the Test 1.5 blend are listed in Table 13. Mixing the $\sim 15$ wt $\%$ solids slurry with another smaller amount of $\sim 25 \mathrm{wt} \%$ produced a mixture with a higher total about 16 wt $\%$.. A sample of the test mixture was submitted for chemical analysis. The results expressed on a wt \% oxide basis are shown in Table B- 31. The agreement between the found and the target composition was reasonable since the target is based upon the originally planned compositions for the waste streams.

Table B- 31: Composition of Test 1.5 Compared to Target

\begin{tabular}{|c|c|c|c|c|c|}
\hline Oxide & Wt \% & Target Wt \% & Oxide & Wt \% & Target Wt \% \\
\hline $\mathrm{Al}_{2} \mathrm{O}_{3}$ & 10.84 & 10.36 & $\mathrm{P}_{2} \mathrm{O}_{5}$ & 2.38 & 0.13 \\
\hline $\mathrm{B}_{2} \mathrm{O}_{3}$ & 0.23 & 0.25 & $\mathrm{PbO}$ & 0.46 & 0.34 \\
\hline $\mathrm{BaO}$ & 0.20 & 0.22 & $\mathrm{SiO}_{2}$ & 3.11 & 2.87 \\
\hline $\mathrm{CaO}$ & 1.23 & 1.41 & $\mathrm{SrO}$ & 6.65 & 6.68 \\
\hline $\mathrm{CdO}$ & 2.48 & 2.4 & $\mathrm{TiO}_{2}$ & 0.06 & 0.05 \\
\hline $\mathrm{CoO}$ & 0.36 & 0.34 & $\mathrm{ZnO}$ & 0.13 & 0.11 \\
\hline $\mathrm{Cr}_{2} \mathrm{O}_{3}$ & 0.36 & 0.32 & $\mathrm{ZrO}$ & 11.72 & 12.17 \\
\hline $\mathrm{CuO}$ & 0.14 & 0.12 & $\mathrm{La}_{2} \mathrm{O}_{3}$ & 1.33 & 1.3 \\
\hline $\mathrm{Fe}_{2} \mathrm{O}_{3}$ & 41.34 & 39.55 & $\mathrm{~K}_{2} \mathrm{O}$ & 0.90 & 0.72 \\
\hline $\mathrm{MgO}$ & 0.1 & 0.27 & $\operatorname{Re}_{2} \mathrm{O}_{7}$ & 0.04 & 0.02 \\
\hline $\mathrm{MnO}$ & 3.45 & 3.69 & $\mathrm{SO}_{3}$ & 0.53 & 0.73 \\
\hline $\mathrm{MoO}_{3}$ & 0.01 & 0.02 & $\mathrm{Ag}_{2} \mathrm{O}$ & 0.20 & 0.23 \\
\hline $\mathrm{Na}_{2} \mathrm{O}$ & 8.24 & 11.92 & $\mathrm{CeO}_{2}$ & 0.36 & 0.31 \\
\hline $\mathrm{NiO}$ & 2.21 & 2.11 & $\mathrm{Nd}_{2} \mathrm{O}_{3}$ & 0.94 & 0.85 \\
\hline
\end{tabular}

Additional tests planned for Test 1.5 required determining the amount of acid needed to shift the test mixture's $\mathrm{pH}$ from 10.17 to values near 9, 7 and 5. A 2.21 gram sample of the mixture was added to $60 \mathrm{~mL}$ of deionized water and titrated with 0.1013 molar hydrochloric acid until the $\mathrm{pH}$ was 5. Figure B - 5 shows the resulting titration curve as a function of the moles of acid added/kilogram of sludge. The shape of the titration curve is controlled by the basic species 
WSRC-TR-2001-00203, Rev. 0

being titrated. For the blended mixture in Test 1.5, the basic species included hydroxide, phosphate and carbonate. The fitted equation shown in Figure B - 5 was empirically obtained using TableCurve ${ }^{\mathrm{TM}}$ 2D software and should not be used to extrapolate beyond the fitted region (pH 11 to $\mathrm{pH}$ 5). Based upon the titration curve, the amount of a monoprotic acid to reach $\mathrm{pH} 9$ was 0.0747 moles per kilogram of the blended mixture. To reach $\mathrm{pH} 7$ the amount of acid was 0.161 moles per kilogram of slurry and for $\mathrm{pH} 5$ the amount was 0.49 moles per kilogram of slurry. The adjustment of the $\mathrm{pH}$ of a portion of Test 1.5 with 10.34 molar nitric acid (50 wt \%) consisted of the following steps:

1. Add 230 grams of Test 1.5 mixture to a tared, $250 \mathrm{~mL}$ bottle and record the weight. Actually used net weight was 229.64 grams. Tare Weight was 28.5 grams.

2. Using a calibrated digital pipette add $1.66 \mathrm{~mL}$ of 10.34 molar nitric acid. Actually added $1.66 \mathrm{~mL}$.

3. Mix thoroughly, measure, and record $\mathrm{pH}$. The measured $\mathrm{pH}$ was 8.43 .

4. Transfer about 30 grams of the $\mathrm{pH}$-adjusted mixture to $30 \mathrm{~mL}$ container labeled as Test $\mathbf{1 . 5}$ pH 9 Adjusted, weigh and record the weight. Amount of slurry removed was 21.28 grams due to the thick, clinging properties of the slurry. This sample was used for rheology measurements.

5. Obtain mass of $\mathrm{pH}$ adjusted $250 \mathrm{~mL}$ bottle and calculate the amount of acid necessary to reduce $\mathrm{pH}$ to 7 . Actual gross mass was 235.69 grams. Tare weight was 28.5 grams.

6. Using a calibrated digital pipette add $1.73 \mathrm{~mL}$ of 10.34 molar nitric acid. Actually added $1.73 \mathrm{~mL}$.

7. Mix thoroughly, measure, and record $\mathrm{pH}$. The measured $\mathrm{pH}$ was 7.03.

8. Transfer about 30 grams of the $\mathrm{pH}$-adjusted mixture to $30 \mathrm{~mL}$ container labeled as Test $\mathbf{1 . 5}$ pH 7 Adjusted, weigh and record the weight. Amount of slurry removed was 20.09 grams due to the thick, clinging properties of the slurry. This sample was used for rheology measurements.

9. Obtain mass of $\mathrm{pH}$ adjusted $250 \mathrm{~mL}$ bottle and calculate the amount of acid necessary to reduce $\mathrm{pH}$ to 5. Actual gross mass was 208.59 grams. Tare weight was 28.5 grams.

10. Using a calibrated digital pipette add $5.73 \mathrm{~mL}$ of 10.34 molar nitric acid. Actually added $5.26 \mathrm{~mL}$.

11. Mix thoroughly, measure, and record $\mathrm{pH}$. The measured $\mathrm{pH}$ was 5.12 .

12. Labeled $250 \mathrm{~mL}$ bottle as Test 1.5 pH 5 Adjusted and used the sample for rheology and chemical analysis.

During the $\mathrm{pH}$ adjustment, gas evolution was observed during the acid addition. The gas produced was probably carbon dioxide due to the conversion of carbonate to bicarbonate and then to carbonic acid $\left(\mathrm{H}_{2} \mathrm{O}+\mathrm{CO}_{2}\right)$. The actual $\mathrm{pH}$ and rheology results for the adjusted Test 1.5 mixtures is discussed in the main section of this report.

\section{Test ADD-1}

Tests ADD-1 and ADD-2 were added to the scope to increase the range of solids being studied, since insoluble solid levels above $20 \mathrm{wt} \%$ were not achievable for the AZ-101 simulated sludge. The goal of Test ADD-1 was to mix $7.5 \mathrm{wt} \%$ insoluble solids AZ-101 sludge with $15 \mathrm{wt} \%$ insoluble solids Sr/TRU precipitate and blended eluate and determine the rheology of the 
WSRC-TR-2001-00203, Rev. 0

mixture. The volume of the mixture needed was at least $500 \mathrm{~mL}$. The following steps were used to make the test mixture:

1. Mass of $7.5 \mathrm{wt} \%$ insoluble solids AZ-101 sludge simulant to use:

$500 \mathrm{~mL} *$ density $(1.065 \mathrm{~g} / \mathrm{mL})=532.5$ grams. Actually used: 532.51 grams.

2. Mass of Sludge Solids is: $532.5 \mathrm{~g} * \mathrm{Wt} \%$ Total Solids $(8.97 \%)=47.77$ grams.

3. The amount of $\mathrm{Sr} / \mathrm{TRU}$ solids required for 47.77 grams of sludge solids is: $47.77 \mathrm{~g} * \mathrm{Sr} / \mathrm{TRU}$ Basis (190.52)/AZ-101 Sludge Basis (1198) = 7.60 grams.

4. The amount of $15 \mathrm{wt} \%$ insoluble solids $\mathrm{Sr} / \mathrm{TRU}$ precipitate to add is:

$7.60 \mathrm{~g} / \mathrm{wt} \%$ total Solids Sr/TRU $(17.65 \%)=43.05$ grams. Actually used: 43.05 grams.

5. The amount of blended eluate to add:

$47.77 \mathrm{~g} *$ Basis for Eluate (11.78)/Basis for AZ-101 (1198) $=0.47$ grams of eluate. Actually used: 0.61 grams.

The physical properties for the Test ADD-1 blend are listed in Table 13. Mixing a $7.5 \mathrm{wt} \%$ solids slurry with a $\sim 15 \mathrm{wt} \%$ solids slurry raises the solids loading from that of the starting base slurry but only by a small amount due to the small amount of Sr/TRU used. A sample of the test mixture was submitted for chemical analysis. The results expressed on a weight percent oxide basis are shown in Table B-32. The agreement between the found and the target wt \% was reasonable, since the target is based upon the originally planned compositions for the waste streams.

Table B- 32: Composition of Test ADD-1 Compared to Target

\begin{tabular}{|c|c|c|c|c|c|}
\hline \multicolumn{2}{|c|}{ Oxide } & Wt \% & \multicolumn{2}{c|}{ Target Wt \% } & \multicolumn{2}{c|}{ Oxide } & Wt \% & Target Wt \% \\
\hline $\mathrm{Al}_{2} \mathrm{O}_{3}$ & 10.44 & 10.36 & $\mathrm{P}_{2} \mathrm{O}_{5}$ & 2.05 & 0.13 \\
\hline $\mathrm{B}_{2} \mathrm{O}_{3}$ & 0.30 & 0.25 & $\mathrm{PbO}$ & 0.43 & 0.34 \\
\hline $\mathrm{BaO}$ & 0.18 & 0.22 & $\mathrm{SiO}_{2}$ & 2.93 & 2.87 \\
\hline $\mathrm{CaO}$ & 1.49 & 1.41 & $\mathrm{SrO}^{2}$ & 6.07 & 6.68 \\
\hline $\mathrm{CdO}$ & 2.38 & 2.4 & $\mathrm{TiO}_{2}$ & 0.05 & 0.05 \\
\hline $\mathrm{CoO}$ & 0.33 & 0.34 & $\mathrm{ZnO}$ & 0.12 & 0.11 \\
\hline $\mathrm{Cr} \mathrm{O}_{3}$ & 0.34 & 0.32 & $\mathrm{ZrO}_{2}$ & 10.75 & 12.17 \\
\hline $\mathrm{CuO}$ & 0.13 & 0.12 & $\mathrm{La}_{2} \mathrm{O}_{3}$ & 1.25 & 1.3 \\
\hline $\mathrm{Fe} \mathrm{O}_{3}$ & 38.03 & 39.55 & $\mathrm{~K}_{2} \mathrm{O}$ & 1.46 & 0.72 \\
\hline $\mathrm{MgO}$ & 0.1 & 0.27 & $\mathrm{Re}_{2} \mathrm{O}_{7}$ & 0.04 & 0.02 \\
\hline $\mathrm{MnO}$ & 3.33 & 3.69 & $\mathrm{SO}_{3}$ & 1.05 & 0.73 \\
\hline $\mathrm{MoO}$ & 0.03 & 0.02 & $\mathrm{Ag}_{2} \mathrm{O}$ & 0.25 & 0.23 \\
\hline $\mathrm{Na} 2 \mathrm{O}$ & 13.3 & 11.92 & $\mathrm{CeO}_{2}$ & 0.34 & 0.31 \\
\hline $\mathrm{NiO}$ & 2.05 & 2.11 & $\mathrm{Nd}_{2} \mathrm{O}_{3}$ & 0.89 & 0.85 \\
\hline
\end{tabular}

\section{Test ADD-2}

The goal of Test ADD-2 was to mix 10 wt \% insoluble solids AZ-101 sludge with 15 wt \% insoluble solids Sr/TRU precipitate and blended eluate and determine the rheology of the mixture. The volume of the mixture needed was at least $500 \mathrm{~mL}$. The following steps were used to make the test mixture: 
1. Mass of $10 \mathrm{wt} \%$ insoluble solids AZ-101 sludge simulant to use: $500 \mathrm{~mL} *$ density $(1.076 \mathrm{~g} / \mathrm{mL})=538$ grams. Actually used: 538 grams.

2. Mass of Sludge Solids is: $538 \mathrm{~g} * \mathrm{Wt} \%$ Total Solids $(11.56 \%)=62.19$ grams.

3. The amount of $\mathrm{Sr} / \mathrm{TRU}$ solids required for 62.19 grams of sludge solids is: $62.19 \mathrm{~g} * \mathrm{Sr} / \mathrm{TRU}$ Basis (190.52)/AZ-101 Sludge Basis (1198) = 9.89 grams.

4. The amount of $15 \mathrm{wt} \%$ insoluble solids $\mathrm{Sr} / \mathrm{TRU}$ precipitate to add is: $9.89 \mathrm{~g} / \mathrm{wt} \%$ total Solids Sr/TRU $(17.65 \%)=56.04$ grams. Actually used: 56.04 grams.

5. The amount of blended eluate to add: $62.19 \mathrm{~g} *$ Basis for Eluate (11.78)/Basis for AZ-101 (1198) = 0.61 grams of eluate. Actually used: 0.64 grams.

The physical properties for the Test ADD-2 blend are listed in Table 13. Mixing a $~ 10$ wt $\%$ solids slurry with a $\sim 15 \mathrm{wt} \%$ solids slurry raises the solids loading from that of the starting base slurry but only by a small amount due to the small amount of Sr/TRU used. A sample of the test mixture was submitted for chemical analysis. The results expressed on a weight $\%$ oxide basis are shown in Table B- 33. The agreement between the found and the target weight $\%$ was reasonable, since the target was based upon the originally planned compositions for the waste streams.

Table B- 33: Composition of Test ADD-2 Compared to Target

\begin{tabular}{|c|c|c|c|c|c|}
\hline \multicolumn{2}{|c|}{ Oxide } & Wt \% & \multicolumn{2}{c|}{ Target Wt \% } & \multicolumn{2}{c|}{ Oxide } & Wt \% & Target Wt \% \\
\hline $\mathrm{Al}_{2} \mathrm{O}_{3}$ & 10.79 & 10.36 & $\mathrm{P}_{2} \mathrm{O}_{5}$ & 2.28 & 0.13 \\
\hline $\mathrm{B}_{2} \mathrm{O}_{3}$ & 0.25 & 0.25 & $\mathrm{PbO}$ & 0.44 & 0.34 \\
\hline $\mathrm{BaO}$ & 0.19 & 0.22 & $\mathrm{SiO}_{2}$ & 2.99 & 2.87 \\
\hline $\mathrm{CaO}$ & 1.39 & 1.41 & $\mathrm{SrO}_{2}$ & 6.06 & 6.68 \\
\hline $\mathrm{CdO}$ & 2.37 & 2.4 & $\mathrm{TiO}_{2}$ & 0.07 & 0.05 \\
\hline $\mathrm{CoO}$ & 0.34 & 0.34 & $\mathrm{ZnO}$ & 0.16 & 0.11 \\
\hline $\mathrm{Cr} \mathrm{O}_{3}$ & 0.35 & 0.32 & $\mathrm{ZrO}_{2}$ & 11.31 & 12.17 \\
\hline $\mathrm{CuO}$ & 0.13 & 0.12 & $\mathrm{La}_{2} \mathrm{O}_{3}$ & 1.29 & 1.3 \\
\hline $\mathrm{Fe}_{2} \mathrm{O}_{3}$ & 39.44 & 39.55 & $\mathrm{~K}_{2} \mathrm{O}$ & 1.23 & 0.72 \\
\hline $\mathrm{MgO}$ & 0.1 & 0.27 & $\mathrm{Re}_{2} \mathrm{O}_{7}$ & 0.03 & 0.02 \\
\hline $\mathrm{MnO}$ & 3.27 & 3.69 & $\mathrm{SO}_{3}$ & 0.82 & 0.73 \\
\hline $\mathrm{MoO}$ & 0.03 & 0.02 & $\mathrm{Ag}_{2} \mathrm{O}$ & 0.25 & 0.23 \\
\hline $\mathrm{Na} 2$ & 11.06 & 11.92 & $\mathrm{CeO}_{2}$ & 0.37 & 0.31 \\
\hline $\mathrm{NiO}$ & 2.12 & 2.11 & $\mathrm{Nd}_{2} \mathrm{O}_{3}$ & 0.88 & 0.85 \\
\hline
\end{tabular}




\section{Blending Basis for the AZ-102 Test Mixtures}

The Waste Treatment Plant of the River Protection Project will blend Envelope D sludge with Sr/TRU precipitate and the concentrated, blended ion exchange eluates to produce a glass waste form with a specified composition. The waste loading in the glass is therefore based on sludge, strontium and cesium loadings. The composition for the AZ-102 simulated sludge, the Sr/TRU precipitate and the blended eluate basis was provided to the Vitreous State Laboratory (VSL) at Catholic University for computation of the necessary blending ratio. The essential factors in developing the blending ratio are the $\mathrm{Al}, \mathrm{Fe}$ and $\mathrm{Zr}$ in the sludge, the strontium in the $\mathrm{Sr} / \mathrm{TRU}$ precipitate and the total cesium in the blended eluate. The blending ratio was derived from the information in Table B- 34 provided by VSL.

Table B- 34: VSL Blending Ratio for AZ-102 Waste Glass

\begin{tabular}{|c|c|c|c|c|c|c|c|}
\hline $\begin{array}{l}\text { Waste } \\
\text { Oxide }\end{array}$ & $\begin{array}{c}\text { AZ102 } \\
\text { Solid (wt } \\
\% \text { ox.) }\end{array}$ & $\begin{array}{c}\text { PNNL's } \\
\text { Composition } \\
\text { of SR/TRU } \\
\text { ppt (wt \% ox.) }\end{array}$ & $\begin{array}{c}\text { SRS's OLI } \\
\text { AZ-102 } \\
\text { Eluate (wt } \\
\% \text { ox.) }\end{array}$ & $\begin{array}{l}\text { Waste } \\
\text { Oxide }\end{array}$ & $\begin{array}{c}\text { AZ102 } \\
\text { Solid (wt } \\
\% \text { ox.) }\end{array}$ & $\begin{array}{c}\text { PNNL's } \\
\text { Composition } \\
\text { of SR/TRU } \\
\text { ppt (wt \% ox.) }\end{array}$ & $\begin{array}{c}\text { SRS's OLI } \\
\text { AZ-102 } \\
\text { Eluate (wt } \\
\% \text { ox.) }\end{array}$ \\
\hline $\mathrm{Ag}_{2} \mathrm{O}$ & $0.06 \%$ & $0.00 \%$ & $0.00 \%$ & $\mathrm{MoO}_{3}$ & $0.00 \%$ & $0.00 \%$ & $0.03 \%$ \\
\hline $\mathrm{Al}_{2} \mathrm{O}_{3}$ & $25.09 \%$ & $0.00 \%$ & $0.00 \%$ & $\mathrm{Na}_{2} \mathrm{O}$ & $8.40 \%$ & $6.77 \%$ & $89.15 \%$ \\
\hline $\mathrm{B}_{2} \mathrm{O}_{3}$ & $0.03 \%$ & $0.00 \%$ & $0.77 \%$ & $\mathrm{Nd}_{2} \mathrm{O}_{3}$ & $0.68 \%$ & $0.04 \%$ & $0.00 \%$ \\
\hline $\mathrm{BaO}$ & $0.12 \%$ & $0.03 \%$ & $0.00 \%$ & $\mathrm{NiO}$ & $2.50 \%$ & $0.02 \%$ & $0.04 \%$ \\
\hline $\mathrm{BeO}$ & $0.01 \%$ & $0.00 \%$ & & $\mathrm{P}_{2} \mathrm{O}_{5}$ & $1.49 \%$ & $0.21 \%$ & $0.50 \%$ \\
\hline $\mathrm{CaO}$ & $1.51 \%$ & $0.61 \%$ & $0.00 \%$ & $\mathrm{PbO}$ & $0.29 \%$ & $0.16 \%$ & $0.08 \%$ \\
\hline $\mathrm{CdO}$ & $4.57 \%$ & $0.00 \%$ & $0.00 \%$ & $\mathrm{SO}_{3}$ & $0.06 \%$ & $0.00 \%$ & \\
\hline $\mathrm{CeO}_{2}$ & $0.19 \%$ & $0.03 \%$ & $0.00 \%$ & $\mathrm{SiO}_{2}$ & $2.06 \%$ & $0.00 \%$ & $0.37 \%$ \\
\hline $\mathrm{Cl}$ & $0.11 \%$ & & & $\mathrm{SnO}_{2}$ & $0.54 \%$ & $0.00 \%$ & $0.00 \%$ \\
\hline $\mathrm{CoO}$ & $0.02 \%$ & $0.00 \%$ & $0.00 \%$ & $\mathrm{SrO}$ & $0.07 \%$ & $60.00 \%$ & \\
\hline $\mathrm{Cr}_{2} \mathrm{O}_{3}$ & $0.29 \%$ & $0.11 \%$ & $1.05 \%$ & $\mathrm{TiO}_{2}$ & $0.03 \%$ & $0.00 \%$ & \\
\hline $\mathrm{Cs}_{2} \mathrm{O}$ & & & $2.73 \%$ & $\mathrm{UO}_{2}$ & $5.27 \%$ & $0.00 \%$ & $2.74 \%$ \\
\hline $\mathrm{CuO}$ & $0.08 \%$ & $0.01 \%$ & $0.00 \%$ & $\mathrm{~V}_{2} \mathrm{O}_{5}$ & $0.01 \%$ & $0.00 \%$ & \\
\hline $\mathrm{F}$ & $0.03 \%$ & $0.00 \%$ & & $\mathrm{Y}_{2} \mathrm{O}_{3}$ & $0.05 \%$ & $0.00 \%$ & \\
\hline $\mathrm{Fe}_{2} \mathrm{O}_{3}$ & $39.29 \%$ & $4.94 \%$ & $0.01 \%$ & $\mathrm{ZnO}$ & $0.13 \%$ & $0.04 \%$ & $0.00 \%$ \\
\hline $\mathrm{K}_{2} \mathrm{O}$ & $0.00 \%$ & $0.00 \%$ & $2.52 \%$ & $\mathrm{ZrO}_{2}$ & $4.80 \%$ & $0.00 \%$ & $0.00 \%$ \\
\hline $\mathrm{La}_{2} \mathrm{O}_{3}$ & $0.97 \%$ & $0.01 \%$ & $0.00 \%$ & TOTAL & $100.00 \%$ & $100.00 \%$ & $100.00 \%$ \\
\hline $\mathrm{MgO}$ & $0.39 \%$ & $0.00 \%$ & $0.00 \%$ & Blending & 250.00 & 20.00 & 2.479 \\
\hline $\mathrm{MnO}$ & $0.85 \%$ & $27.02 \%$ & $0.00 \%$ & \multicolumn{2}{|c|}{ Ratio (wt of oxides) } & & 272.48 \\
\hline
\end{tabular}

The blending ratio was based upon waste oxides for each of the three streams. The waste oxide values were converted to total solids values for the AZ-102 simulated sludge and for the Sr/TRU precipitate by dividing by the appropriate calcine factor. The calcine factor for the AZ-102 sludge was 0.868 , which makes the total solids of AZ-102 sludge 287.91 grams. The calcine factor for the Sr/TRU precipitate was 0.747 . Therefore, the Sr/TRU basis was 26.77 grams of Sr/TRU solids per 287.91 grams of AZ-102 sludge solids. The basis for the blended eluate was converted to grams of liquid basis by dividing the 2.479 grams of waste oxides by the total waste oxides/liter (69.03 grams) and multiplying by the solution density. The result was 39.75 grams of blended eluate liquid to be added for 287.91 grams of AZ-102 sludge solids. Comparison 
WSRC-TR-2001-00203, Rev. 0

SRT-RPP-2001-00051, Rev. 0

TRPT-24590-01-00001

with the blending ratio for the AZ-101 waste glass revealed that nearly ten times more eluate was added to the AZ-102 mixtures than to the AZ-101 mixtures. The application of these ratios is discussed with each test mixture.

\section{Test 2.3}

The goal of Test 2.3 was to mix $20 \mathrm{wt} \%$ insoluble solids AZ-102 sludge with $20 \mathrm{wt} \%$ insoluble solids Sr/TRU precipitate and blended eluate and determine the rheology of the mixture. The volume of the mixture needed was at least $600 \mathrm{~mL}$. The following steps were used to make the test mixture:

1. Mass of $20 \mathrm{wt} \%$ insoluble solids AZ-102 sludge simulant to use: $600 \mathrm{~mL} *$ density $(1.169 \mathrm{~g} / \mathrm{mL})=701.4$ grams. Actually used: 699.2 grams.

2. Mass of Sludge Solids is: $701.4 \mathrm{~g} * \mathrm{Wt} \%$ Total Solids $(20.53 \%)=144.0$ grams.

3. The amount of $\mathrm{Sr} / \mathrm{TRU}$ solids required for 144.0 grams of sludge solids is: $144.0 \mathrm{~g} * \mathrm{Sr} / \mathrm{TRU}$ Basis (26.77)/AZ-102 Sludge Basis $(287.91)=13.39$ grams.

4. The amount of $20 \mathrm{wt} \%$ insoluble solids Sr/TRU precipitate to add is: $13.39 \mathrm{~g} / \mathrm{wt} \%$ total Solids Sr/TRU $(22.52 \%)=59.46$ grams.

Actually used: 59.60 grams.

5. The amount of blended eluate to add:

$144.0 \mathrm{~g} *$ Basis for Eluate $(39.75) /$ Basis for AZ-102 (287.91) $=19.88$ grams of eluate. Actually used: 19.90 grams.

The physical properties for the Test 2.3 blend are listed in Table 14. Mixing a $\sim 20 \mathrm{wt} \%$ solids slurry with another $\sim 20 \mathrm{wt} \%$ solids did not result in diluting the measured solids for the mixture. A sample of the test mixture was submitted for chemical analysis. The results expressed on a weight $\%$ oxide basis are shown in Table B- 35. The agreement between the found and the target weight $\%$ was reasonable, since the target was based upon the originally planned compositions for the waste streams.

Table B- 35: Composition of Test 2.3 Compared to Target

\begin{tabular}{|c|c|c|c|c|c|}
\hline Oxide & Wt \% & Target Wt \% & Oxide & Wt \% & Target Wt \% \\
\hline $\mathrm{Al}_{2} \mathrm{O}_{3}$ & 25.66 & 23.01 & $\mathrm{P}_{2} \mathrm{O}_{5}$ & 0.43 & 1.39 \\
\hline $\mathrm{BaO}$ & 0.16 & 0.11 & $\mathrm{PbO}$ & 0.07 & 0.28 \\
\hline $\mathrm{CaO}$ & 0.66 & 1.43 & $\mathrm{SiO}_{2}$ & 2.38 & 1.9 \\
\hline $\mathrm{CdO}$ & 5.4 & 4.19 & $\mathrm{SrO}$ & 3.57 & 4.47 \\
\hline $\mathrm{CoO}$ & 0.03 & 0.02 & $\mathrm{TiO}_{2}$ & 0.02 & 0.03 \\
\hline $\mathrm{Cr}_{2} \mathrm{O}_{3}$ & 0.36 & 0.28 & $\mathrm{ZnO}$ & 0.19 & 0.12 \\
\hline $\mathrm{CuO}$ & 0.06 & 0.08 & $\mathrm{ZrO}$ & 5.57 & 4.4 \\
\hline $\mathrm{Fe}_{2} \mathrm{O}_{3}$ & 46.53 & 36.39 & $\overline{\mathrm{La}_{2} \mathrm{O}_{3}}$ & 1.15 & 0.89 \\
\hline $\mathrm{MgO}$ & 0.46 & 0.36 & $\mathrm{~K}_{2} \mathrm{O}$ & 0.12 & 0.02 \\
\hline $\mathrm{MnO}$ & 2.53 & 2.76 & $\mathrm{Ag}_{2} \mathrm{O}$ & 0.09 & 0.06 \\
\hline $\mathrm{MoO}_{3}$ & 0 & 0 & $\mathrm{CeO}_{2}$ & 0.26 & 0.17 \\
\hline $\mathrm{Na}_{2} \mathrm{O}$ & 4.25 & 9.04 & $\mathrm{Nd}_{2} \mathrm{O}_{3}$ & 0.06 & 0.63 \\
\hline
\end{tabular}

Additional tests planned for Test 2.3 required determining the amount of acid needed to shift the test mixture's $\mathrm{pH}$ from 11.24 to values near 9,7 and 5. A 2.22 gram sample of the mixture was added to $60 \mathrm{~mL}$ of deionized water and titrated with 0.1013 molar hydrochloric acid until the $\mathrm{pH}$ 
WSRC-TR-2001-00203, Rev. 0

was 5. Figure B - 6 shows the resulting titration curve as a function of the moles of acid added/kilogram of sludge. The shape of the titration curve is controlled by the basic species being titrated. For the blended mixture in Test 2.3, the basic species included hydroxide, phosphate and carbonate. The fitted equation shown in Figure B - 6 was empirically obtained using TableCurve ${ }^{\mathrm{TM}}$ 2D software and should not be used to extrapolate beyond the fitted region ( $\mathrm{pH} 11$ to $\mathrm{pH}$ 4.75). Based upon the titration curve, the amount of a monoprotic acid to reach $\mathrm{pH}$ 9 was 0.1045 moles per kilogram of the blended mixture. To reach $\mathrm{pH} 7$ the amount of acid was 0.201 moles per kilogram of slurry and for $\mathrm{pH} 5$ the amount was 0.431 moles per kilogram of slurry. The adjustment of the $\mathrm{pH}$ of a portion of Test 2.3 with 10.34 molar nitric acid (50 wt \%) consisted of the following steps:

1. Add 230 grams of Test 2.3 mixture to a tared, $250 \mathrm{~mL}$ bottle and record the weight. Actually used net weight was 249.48 grams. Tare Weight was 29.52 grams.

2. Using a calibrated digital pipette add $2.52 \mathrm{~mL}$ of 10.34 molar nitric acid. Actually added $2.52 \mathrm{~mL}$.

3. Mix thoroughly, measure, and record $\mathrm{pH}$. The measured $\mathrm{pH}$ was 8.61 .

4. Transfer about 30 grams of the $\mathrm{pH}$-adjusted mixture to $30 \mathrm{~mL}$ container labeled as Test $\mathbf{2 . 3}$ pH 9 Adjusted, weigh and record the weight. Amount of slurry removed was 19.48 grams due to the sticky nature of the slurry. This sample was used for rheology measurements.

5. Obtain mass of $\mathrm{pH}$ adjusted $250 \mathrm{~mL}$ bottle and calculate the amount of acid necessary to reduce $\mathrm{pH}$ to 7 . Actual gross mass was 258.74 grams. Tare weight was 29.52 grams.

6. Using a calibrated digital pipette add $2.14 \mathrm{~mL}$ of 10.34 molar nitric acid. Actually added $2.14 \mathrm{~mL}$.

7. Mix thoroughly, measure, and record $\mathrm{pH}$. The measured $\mathrm{pH}$ was 6.75 .

8. Transfer about 30 grams of the $\mathrm{pH}$-adjusted mixture to $30 \mathrm{~mL}$ container labeled as Test $\mathbf{2 . 3}$ pH 7 Adjusted, weigh and record the weight. Amount of slurry removed was 18.60 grams due to the sticky nature of the slurry. This sample was used for rheology measurements.

9. Obtain mass of $\mathrm{pH}$ adjusted $250 \mathrm{~mL}$ bottle and calculate the amount of acid necessary to reduce $\mathrm{pH}$ to 5. Actual gross mass was 233.42 grams. Tare weight was 29.52 grams.

10. Using a calibrated digital pipette add $4.53 \mathrm{~mL}$ of 10.34 molar nitric acid. Actually added $4.53 \mathrm{~mL}$.

11. Mix thoroughly, measure, and record $\mathrm{pH}$. The measured $\mathrm{pH}$ was 4.77 .

12. Labeled the $250 \mathrm{~mL}$ bottle as Test 2.3 pH 5 Adjusted and used the sample for rheology and chemical analysis.

During the $\mathrm{pH}$ adjustment, gas evolution was observed during the acid addition. The gas produced was probably carbon dioxide due to the conversion of carbonate to bicarbonate and then to carbonic acid $\left(\mathrm{H}_{2} \mathrm{O}+\mathrm{CO}_{2}\right)$. The actual $\mathrm{pH}$ and rheology results for the adjusted Test 2.3 mixtures is discussed in the main section of this report. 
Figure B - 6: Test Mix 2.3 Titration Curve

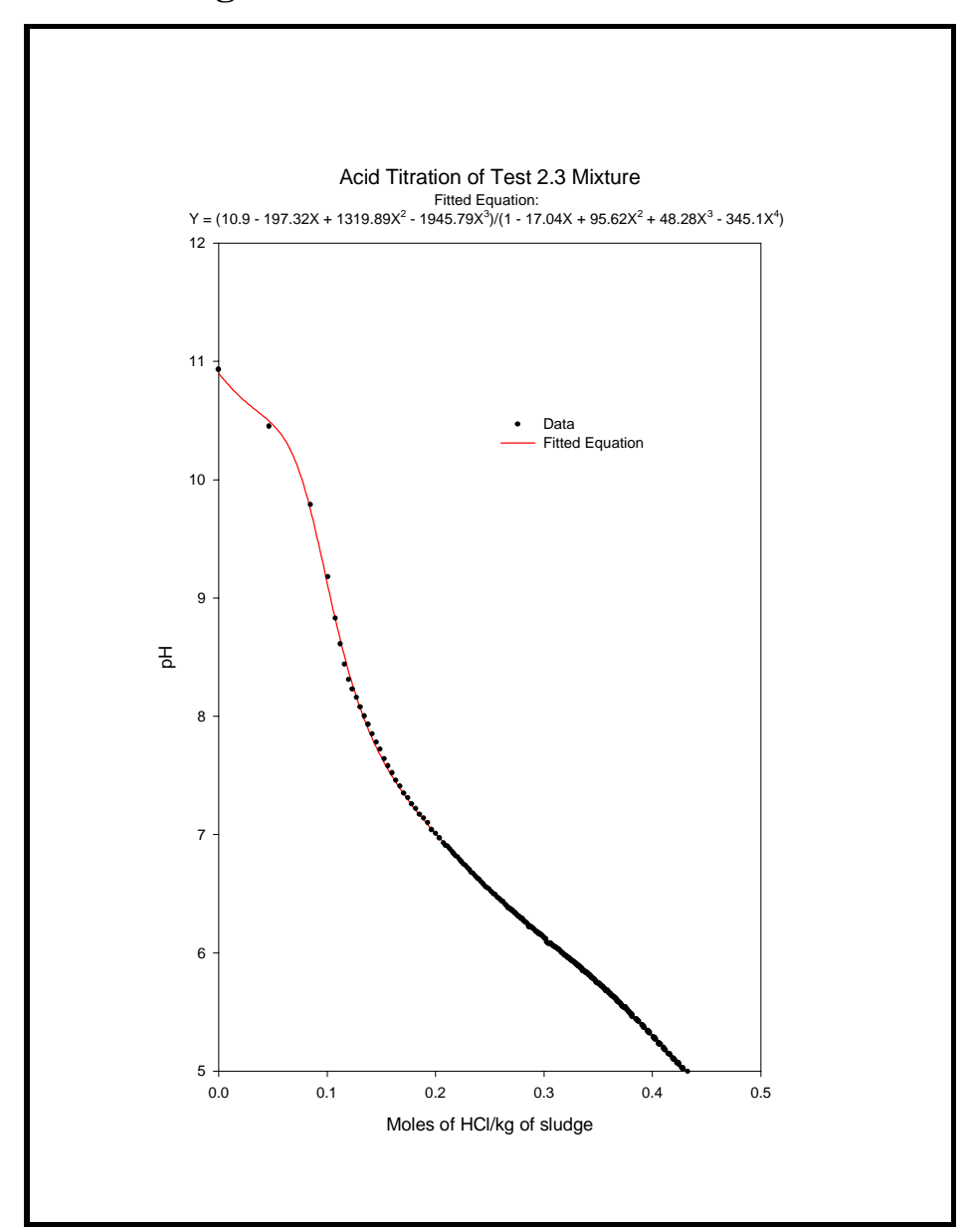

Figure B - 7: Test Mixture 2.5 Titration Curve

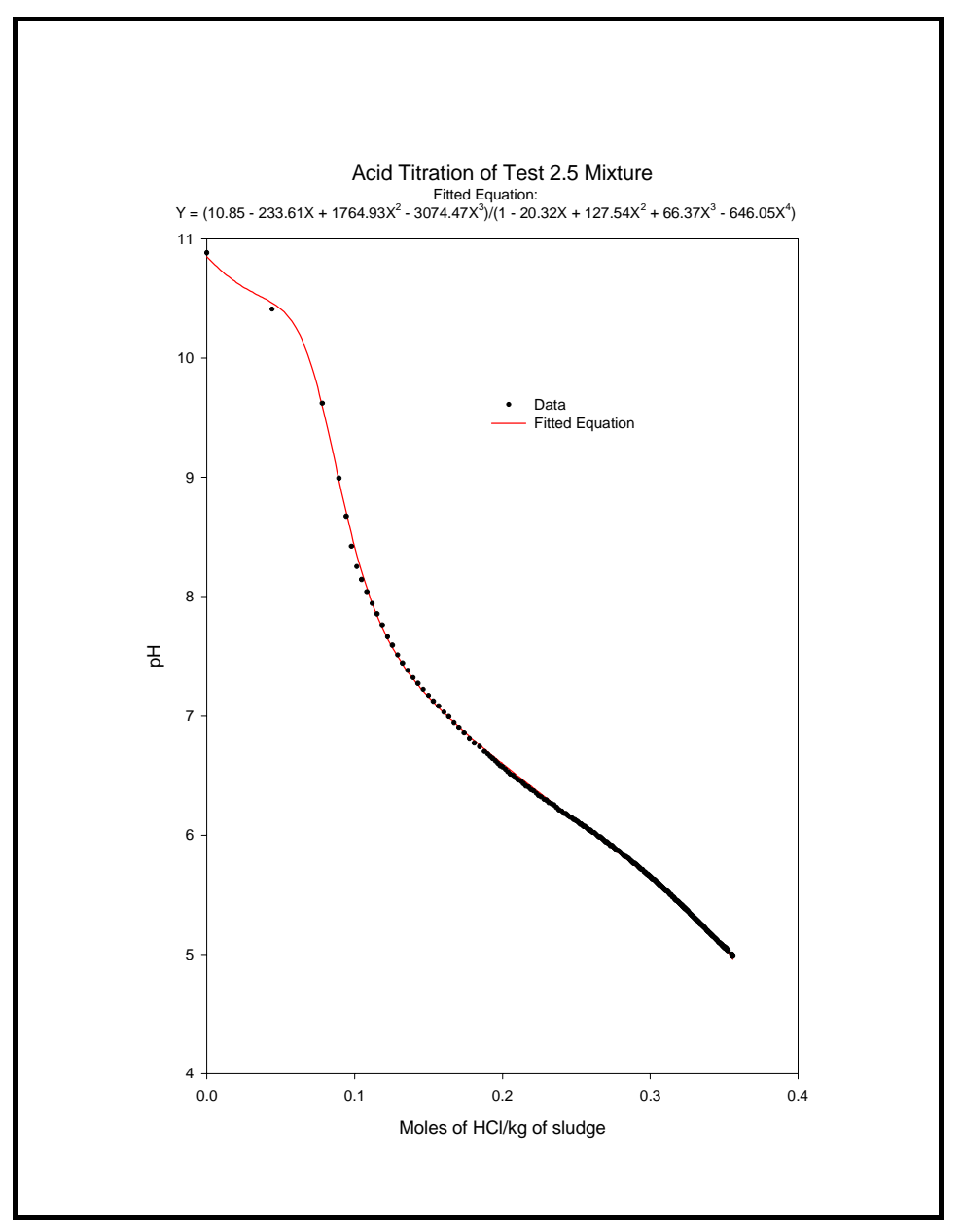




\section{Test 2.4}

The goal of Test 2.4 was to mix 15 wt \% insoluble solids AZ-102 sludge with 15 wt \% insoluble solids Sr/TRU precipitate and blended eluate and determine the rheology of the mixture. The volume of the mixture needed was at least $500 \mathrm{~mL}$. The following steps were used to make the test mixture:

1. Mass of $15 \mathrm{wt} \%$ insoluble solids AZ-102 sludge simulant to use:

$500 \mathrm{~mL} *$ density $(1.114 \mathrm{~g} / \mathrm{mL})=557$ grams. Actually used: 557.03 grams.

2. Mass of Sludge Solids is: $557 \mathrm{~g} * \mathrm{Wt} \%$ Total Solids $(15.57 \%)=86.72$ grams.

3. The amount of $\mathrm{Sr} / \mathrm{TRU}$ solids required for 86.72 grams of sludge solids is: $86.72 \mathrm{~g} * \mathrm{Sr} / \mathrm{TRU}$ Basis (26.77)/AZ-102 Sludge Basis (287.91) = 8.06 grams.

4. The amount of $15 \mathrm{wt} \%$ insoluble solids $\mathrm{Sr} / \mathrm{TRU}$ precipitate to add is:

$8.06 \mathrm{~g} / \mathrm{wt} \%$ total Solids Sr/TRU $(17.65 \%)=45.67$ grams.

Actually used: 45.77 grams.

5. The amount of blended eluate to add:

$86.72 \mathrm{~g} *$ Basis for Eluate (39.75)/Basis for AZ-102 (287.91) = 11.97 grams of eluate.

Actually used: 11.98 grams.

The physical properties for the Test 2.4 blend are listed in Table 14. Mixing a $\sim 15$ wt $\%$ solids slurry with another $\sim 15 \mathrm{wt} \%$ solids did not result in diluting the measured solids for the mixture. A sample of the test mixture was submitted for chemical analysis. The results expressed on a wt $\%$ oxide basis are shown in Table B- 36. The agreement between the found and the target composition was reasonable, since the target wt \% was based upon the originally planned compositions for the waste streams.

Table B- 36: Composition of Test 2.4 Compared to Target

\begin{tabular}{|c|c|c|c|c|c|}
\hline \multicolumn{2}{|c|}{ Oxide } & Wt \% & \multicolumn{2}{c|}{ Target Wt \% } & \multicolumn{2}{c|}{ Oxide } & \multicolumn{2}{c|}{ Wt \% } & Target Wt \% \\
\hline $\mathrm{Al}_{2} \mathrm{O}_{3}$ & 26.89 & 23.01 & $\mathrm{P}_{2} \mathrm{O}_{5}$ & 0.94 & 1.39 \\
\hline $\mathrm{BaO}$ & 0.15 & 0.11 & $\mathrm{PbO}$ & 0.08 & 0.28 \\
\hline $\mathrm{CaO}$ & 0.74 & 1.43 & $\mathrm{SiO}_{2}$ & 2.35 & 1.9 \\
\hline $\mathrm{CdO}$ & 5.12 & 4.19 & $\mathrm{SrO}$ & 3.44 & 4.47 \\
\hline $\mathrm{CoO}$ & 0.03 & 0.02 & $\mathrm{TiO}_{2}$ & 0.03 & 0.03 \\
\hline $\mathrm{Cr} \mathrm{O}_{3}$ & 0.34 & 0.28 & $\mathrm{ZnO}$ & 0.19 & 0.12 \\
\hline $\mathrm{CuO}$ & 0.02 & 0.08 & $\mathrm{ZrO}_{2}$ & 5.53 & 4.4 \\
\hline $\mathrm{Fe}_{2} \mathrm{O}_{3}$ & 44.87 & 36.39 & $\mathrm{La}_{2} \mathrm{O}_{3}$ & 1.14 & 0.89 \\
\hline $\mathrm{MgO}$ & 0.45 & 0.36 & $\mathrm{~K}_{2} \mathrm{O}$ & 0.09 & 0.02 \\
\hline $\mathrm{MnO}$ & 2.41 & 2.76 & $\mathrm{Ag}_{2} \mathrm{O}$ & 0.08 & 0.06 \\
\hline $\mathrm{MoO}$ & 0.05 & 0 & $\mathrm{CeO}_{2}$ & 0.25 & 0.17 \\
\hline $\mathrm{Na}_{2} \mathrm{O}$ & 4.71 & 9.04 & $\mathrm{Nd}_{2} \mathrm{O}_{3}$ & 0.09 & 0.63 \\
\hline
\end{tabular}

\section{Test 2.5}

The goal of Test 2.5 was to mix 15 wt \% insoluble solids AZ-102 sludge with 25 wt \% insoluble solids Sr/TRU precipitate and blended eluate and determine the rheology of the mixture. The volume of the mixture needed was at least $500 \mathrm{~mL}$. The following steps were used to make the test mixture: 
1. Mass of $15 \mathrm{wt} \%$ insoluble solids AZ-102 sludge simulant to use: $500 \mathrm{~mL} *$ density $(1.114 \mathrm{~g} / \mathrm{mL})=557$ grams. Actually used: 557.0 grams.

2. Mass of Sludge Solids is: $557 \mathrm{~g} * \mathrm{Wt} \%$ Total Solids $(15.57 \%)=86.72$ grams.

3. The amount of $\mathrm{Sr} / \mathrm{TRU}$ solids required for 86.72 grams of sludge solids is: $86.72 \mathrm{~g} * \mathrm{Sr} / \mathrm{TRU}$ Basis (26.77)/AZ-102 Sludge Basis $(287.91)=8.06$ grams.

4. The amount of $25 \mathrm{wt} \%$ insoluble solids $\mathrm{Sr} / \mathrm{TRU}$ precipitate to add is: $8.06 \mathrm{~g} / \mathrm{wt} \%$ total Solids Sr/TRU $(27.32 \%)=29.50$ grams.

Actually used: 29.53 grams.

5. The amount of blended eluate to add:

$8.06 \mathrm{~g} *$ Basis for Eluate (39.75)/Basis for AZ-102 $(287.91)=11.97$ grams of eluate.

Actually used: 12.0 grams.

The physical properties for the Test 2.5 blend are listed in Table 14. Mixing a $\sim 15$ wt $\%$ solids slurry with a $\sim 25 \mathrm{wt} \%$ solids did not significantly increase the measured solids for the mixture due to the small amount of Sr/TRU added. A sample of the test mixture was submitted for chemical analysis. The results expressed on a wt \% oxide basis are shown in Table B- 37. The agreement between the found and the target is reasonable since the target is based upon the originally planned compositions for the waste streams.

Table B- 37: Composition of Test 2.5 Compared to Target Blend

\begin{tabular}{|c|c|c|c|c|c|}
\hline \multicolumn{2}{|c|}{ Oxide } & Wt \% & \multicolumn{2}{c|}{ Target Wt \% } & \multicolumn{2}{c|}{ Oxide } & Wt \% & Target Wt \% \\
\hline $\mathrm{Al}_{2} \mathrm{O}_{3}$ & 27.3 & 23.01 & $\mathrm{P}_{2} \mathrm{O}_{5}$ & 0.89 & 1.39 \\
\hline $\mathrm{BaO}$ & 0.15 & 0.11 & $\mathrm{PbO}$ & 0.08 & 0.28 \\
\hline $\mathrm{CaO}$ & 0.73 & 1.43 & $\mathrm{SiO}_{2}$ & 2.28 & 1.9 \\
\hline $\mathrm{CdO}$ & 5.06 & 4.19 & $\mathrm{SrO}$ & 3.65 & 4.47 \\
\hline $\mathrm{CoO}$ & 0.02 & 0.02 & $\mathrm{TiO}_{2}$ & 0.03 & 0.03 \\
\hline $\mathrm{Cr} \mathrm{O}_{3}$ & 0.34 & 0.28 & $\mathrm{ZnO}$ & 0.18 & 0.12 \\
\hline $\mathrm{CuO}$ & 0.02 & 0.08 & $\mathrm{ZrO}_{2}$ & 5.53 & 4.4 \\
\hline $\mathrm{Fe}_{2} \mathrm{O}_{3}$ & 44.57 & 36.39 & $\mathrm{La}_{2} \mathrm{O}_{3}$ & 1.12 & 0.89 \\
\hline $\mathrm{MgO}$ & 0.45 & 0.36 & $\mathrm{~K}_{2} \mathrm{O}$ & 0.14 & 0.02 \\
\hline $\mathrm{MnO}$ & 2.52 & 2.76 & $\mathrm{Ag}_{2} \mathrm{O}$ & 0.09 & 0.06 \\
\hline $\mathrm{MoO}_{3}$ & 0.01 & 0 & $\mathrm{CeO}_{2}$ & 0.26 & 0.17 \\
\hline $\mathrm{Na}_{2} \mathrm{O}$ & 4.49 & 9.04 & $\mathrm{Nd}_{2} \mathrm{O}_{3}$ & 0.1 & 0.63 \\
\hline
\end{tabular}

Additional tests planned for Test 2.5 required determining the amount of acid needed to shift the test mixture's pH from 11.14 to values near 9, 7 and 5. A 2.34 gram sample of the mixture was added to $60 \mathrm{~mL}$ of deionized water and titrated with 0.1013 molar hydrochloric acid until the pH was 5 .

Figure B - 7 shows the resulting titration curve as a function of the moles of acid adted/kilogram of sludge. The shape of the titration curve is controlled by the basic species being titrated. For the blended mixture in Test 2.5, the basic species include hydroxide, phosphate and carbonate. The fitted equation shown in Figure B - 7 was empirically obtained using TableCurve ${ }^{\mathrm{TM}}$ 2D software and should not be used to extrapolate beyond the fitted region ( $\mathrm{pH} 11$ to $\mathrm{pH} 4.75)$. Based upon the titration curve, the amount of a monoprotic acid to reach $\mathrm{pH} 9$ was 0.0892 moles per kilogram of the blended mixture. To reach pH 7 the amount of acid was 0.162 moles per 
WSRC-TR-2001-00203, Rev. 0

kilogram of slurry and for $\mathrm{pH} 5$ the amount was 0.355 moles per kilogram of slurry. The adjustment of the $\mathrm{pH}$ of a portion of Test 2.5 with 10.34 molar nitric acid (50 wt \%) consisted of the following steps:

1. Add 230 grams of Test 2.5 mixture to a tared, $250 \mathrm{~mL}$ bottle and record the weight. Actually used net weight was 249.69 grams. Tare Weight was 29.27 grams.

2. Using a calibrated digital pipette add $2.15 \mathrm{~mL}$ of 10.34 molar nitric acid. Actually added $2.15 \mathrm{~mL}$.

3. Mix thoroughly, measure, and record $\mathrm{pH}$. The measured $\mathrm{pH}$ was 8.75 .

4. Transfer about 30 grams of the $\mathrm{pH}$-adjusted mixture to $30 \mathrm{~mL}$ container labeled as Test $\mathbf{2 . 5}$ pH 9 Adjusted, weigh and record the weight. Amount of slurry removed was 20.18 grams due to the thick, sticky properties of the slurry. This sample was used for rheology measurements.

5. Obtain mass of $\mathrm{pH}$ adjusted $250 \mathrm{~mL}$ bottle and calculate the amount of acid necessary to reduce $\mathrm{pH}$ to 7 . Actual gross mass was 259.02 grams. Tare weight was 29.27 grams.

6. Using a calibrated digital pipette add $1.61 \mathrm{~mL}$ of 10.34 molar nitric acid. Actually added $1.61 \mathrm{~mL}$.

7. Mix thoroughly, measure, and record $\mathrm{pH}$. The measured $\mathrm{pH}$ was 6.68 .

8. Transfer about 30 grams of the $\mathrm{pH}$-adjusted mixture to $30 \mathrm{~mL}$ container labeled as Test $\mathbf{2 . 5}$ pH 7 Adjusted, weigh and record the weight. Amount of slurry removed was 16.94 grams due to the thick, sticky properties of the slurry. This sample was used for rheology measurements.

9. Obtain mass of $\mathrm{pH}$ adjusted $250 \mathrm{~mL}$ bottle and calculate the amount of acid necessary to reduce $\mathrm{pH}$ to 5. Actual gross mass was 241.59 grams. Tare weight was 29.27 grams.

10. Using a calibrated digital pipette add $3.97 \mathrm{~mL}$ of 10.34 molar nitric acid. Actually added $3.97 \mathrm{~mL}$.

11. Mix thoroughly, measure, and record $\mathrm{pH}$. The measured $\mathrm{pH}$ was 4.72 .

12. Labeled the $250 \mathrm{~mL}$ bottle as Test 2.5 pH 5 Adjusted and used the sample for rheology and chemical analysis.

During the $\mathrm{pH}$ adjustment, gas evolution was observed during the acid addition. The gas produced was probably carbon dioxide due to the conversion of carbonate to bicarbonate and then to carbonic acid $\left(\mathrm{H}_{2} \mathrm{O}+\mathrm{CO}_{2}\right)$. The actual $\mathrm{pH}$ and rheology results for the adjusted Test 2.5 mixtures is discussed in the results section of this report.

\section{Test 2.9}

The goal of Test 2.9 was to mix 20 wt \% insoluble solids AZ-102 sludge with blended eluate and determine the rheology of the mixture. The volume of the mixture needed was at least $600 \mathrm{~mL}$. The following steps were used to make the test mixture:

1. Mass of $20 \mathrm{wt} \%$ insoluble solids AZ-102 sludge simulant to use: $600 \mathrm{~mL} *$ density $(1.169 \mathrm{~g} / \mathrm{mL})=701.4$ grams. Actually used: 700.26 grams.

2. Mass of Sludge Solids is: $701.4 \mathrm{~g} * \mathrm{Wt} \%$ Total Solids $(20.53 \%)=144$ grams.

3. The amount of blended eluate to add: $144 \mathrm{~g} *$ Basis for Eluate $(39.75)$ /Basis for AZ-102 $(287.91)=19.88$ grams of eluate. Actually used: 19.89 grams. 
The physical properties for the Test 2.9 blend are listed in Table 14. The mixture was essentially the same as the $20 \mathrm{wt} \%$ insoluble solids AZ-102 sludge, just diluted a little bit by the eluate. A sample of the test mixture was submitted for chemical analysis. The results expressed on a wt $\%$ oxide basis are shown in Table B- 38. The agreement between the found and the target composition was reasonable, since the target was based upon the originally planned compositions for the waste streams.

Table B- 38: Composition of Test 2.9 Compared to Target Blend

\begin{tabular}{|c|c|c|c|c|c|}
\hline Oxide & Wt \% & Target Wt \% & Oxide & Wt \% & Target Wt $\%$ \\
\hline $\mathrm{Al}_{2} \mathrm{O}_{3}$ & 28.86 & 24.83 & $\mathrm{P}_{2} \mathrm{O}_{5}$ & 0.84 & 1.48 \\
\hline $\mathrm{BaO}$ & 0.16 & 0.12 & $\mathrm{PbO}$ & 0.04 & 0.28 \\
\hline $\mathrm{CaO}$ & 0.49 & 1.49 & $\mathrm{SiO}_{2}$ & 2.67 & 2.05 \\
\hline $\mathrm{CdO}$ & 5.49 & 4.52 & $\mathrm{SrO}$ & 0 & 0.07 \\
\hline $\mathrm{CoO}$ & 0.03 & 0.02 & $\mathrm{TiO}_{2}$ & 0.04 & 0.03 \\
\hline $\mathrm{Cr}_{2} \mathrm{O}_{3}$ & 0.35 & 0.3 & $\mathrm{ZnO}$ & 0.19 & 0.13 \\
\hline $\mathrm{CuO}$ & 0.01 & 0.08 & $\mathrm{ZrO}$ & 6.24 & 4.75 \\
\hline $\mathrm{Fe}_{2} \mathrm{O}_{3}$ & 47.8 & 38.88 & $\mathrm{La}_{2} \mathrm{O}_{3}$ & 1.21 & 0.96 \\
\hline $\mathrm{MgO}$ & 0.48 & 0.39 & $\mathrm{~K}_{2} \mathrm{O}$ & 0.08 & 0.03 \\
\hline $\mathrm{MnO}$ & 1.07 & 0.84 & $\mathrm{Ag}_{2} \mathrm{O}$ & 0.08 & 0.06 \\
\hline $\mathrm{MoO}_{3}$ & 0.01 & 0 & $\mathrm{CeO}_{2}$ & 0.28 & 0.19 \\
\hline $\mathrm{Na}_{2} \mathrm{O}$ & 3.54 & 9.22 & $\mathrm{Nd}_{2} \mathrm{O}_{3}$ & 0.03 & 0.68 \\
\hline
\end{tabular}

\section{Test ADD-3}

The goal of Test ADD-3 was to mix 10 wt \% insoluble solids AZ-102 sludge with 15 wt \% insoluble solids Sr/TRU precipitate and blended eluate and determine the rheology of the mixture. The volume of the mixture needed was at least $500 \mathrm{~mL}$. The following steps were used to make the test mixture:

1. Mass of $10 \mathrm{wt} \%$ insoluble solids AZ-102 sludge simulant to use: $500 \mathrm{~mL} *$ density $(1.0709 \mathrm{~g} / \mathrm{mL})=535.45$ grams. Actually used: 535.45 grams.

2. Mass of Sludge Solids is: $535.45 \mathrm{~g} * \mathrm{Wt} \%$ Total Solids $(10.59 \%)=56.7$ grams.

3. The amount of Sr/TRU solids required for 56.7 grams of sludge solids is: $56.7 \mathrm{~g} *$ Sr/TRU Basis (26.77)/AZ-102 Sludge Basis (287.91) = 5.27 grams.

4. The amount of $15 \mathrm{wt} \%$ insoluble solids Sr/TRU precipitate to add is: $5.27 \mathrm{~g} / \mathrm{wt} \%$ total Solids Sr/TRU $(17.65 \%)=29.86$ grams. Actually used: 29.88 grams.

5. The amount of blended eluate to add:

$56.7 \mathrm{~g} *$ Basis for Eluate (39.75)/Basis for AZ-102 (287.91) = 7.83 grams of eluate. Actually used: 7.83 grams.

The physical properties for the Test ADD-3 blend are listed in Table 14. Mixing a $~ 10$ wt $\%$ solids slurry with a smaller amount of a $\sim 15 \mathrm{wt} \%$ solids did not significantly change the weight percent solids for the mixture. A sample of the test mixture was submitted for chemical analysis. The results expressed on a wt \% oxide basis are shown in Table B- 39. The agreement between 
WSRC-TR-2001-00203, Rev. 0

the found and the target composition was reasonable, since the target wt $\%$ was based upon the originally planned compositions for the waste streams.

Table B- 39: Composition of Test ADD-3 Compared to Target Blend

\begin{tabular}{|c|c|c|c|c|c|}
\hline \multicolumn{2}{c}{ Oxide } & Wt \% & \multicolumn{2}{c|}{ Target Wt \% } & \multicolumn{2}{c|}{ Oxide } & \multicolumn{1}{c|}{ Wt \% } & Target Wt \% \\
\hline $\mathrm{Al}_{2} \mathrm{O}_{3}$ & 27.46 & 23.01 & $\mathrm{P}_{2} \mathrm{O}_{5}$ & 0.94 & 1.39 \\
\hline $\mathrm{BaO}$ & 0.15 & 0.11 & $\mathrm{PbO}$ & 0.09 & 0.28 \\
\hline $\mathrm{CaO}$ & 0.89 & 1.43 & $\mathrm{SiO}_{2}$ & 2.45 & 1.9 \\
\hline $\mathrm{CdO}$ & 4.92 & 4.19 & $\mathrm{SrO}$ & 3.37 & 4.47 \\
\hline $\mathrm{CoO}$ & 0.02 & 0.02 & $\mathrm{TiO}_{2}$ & 0.03 & 0.03 \\
\hline $\mathrm{Cr} \mathrm{O}_{3}$ & 0.33 & 0.28 & $\mathrm{ZnO}$ & 0.18 & 0.12 \\
\hline $\mathrm{CuO}$ & 0.01 & 0.08 & $\mathrm{ZrO}$ & 5.11 & 4.4 \\
\hline $\mathrm{Fe}_{2} \mathrm{O}_{3}$ & 43.77 & 36.39 & $\mathrm{La}_{2} \mathrm{O}_{3}$ & 1.08 & 0.89 \\
\hline $\mathrm{MgO}$ & 0.44 & 0.36 & $\mathrm{~K}_{2} \mathrm{O}$ & 0.37 & 0.02 \\
\hline $\mathrm{MnO}$ & 2.36 & 2.76 & $\mathrm{Ag}_{2} \mathrm{O}$ & 0.07 & 0.06 \\
\hline $\mathrm{MoO}_{3}$ & 0.02 & 0 & $\mathrm{CeO}_{2}$ & 0.2 & 0.17 \\
\hline $\mathrm{Na}_{2} \mathrm{O}$ & 5.06 & 9.04 & $\mathrm{Nd}_{2} \mathrm{O}_{3}$ & 0.13 & 0.63 \\
\hline
\end{tabular}

\section{Test ADD-4}

The goal of Test ADD-4 was to mix $12.5 \mathrm{wt} \%$ insoluble solids AZ-102 sludge with 15 wt \% insoluble solids $\mathrm{Sr}$ /TRU precipitate and blended eluate and determine the rheology of the mixture. The volume of the mixture needed was at least $500 \mathrm{~mL}$. The following steps were used to make the test mixture:

1. Mass of $12.5 \mathrm{wt} \%$ insoluble solids AZ-102 sludge simulant to use: $500 \mathrm{~mL} *$ density $(1.0845 \mathrm{~g} / \mathrm{mL})=542.25$ grams. Actually used: 542.25 grams.

2. Mass of Sludge Solids is: $542.25 \mathrm{~g} * \mathrm{Wt} \%$ Total Solids $(12.82 \%)=69.52$ grams.

3. The amount of Sr/TRU solids required for 69.52 grams of sludge solids is: $69.52 \mathrm{~g} * \mathrm{Sr} / \mathrm{TRU}$ Basis (26.77)/AZ-102 Sludge Basis (287.91) = 6.46 grams.

4. The amount of $15 \mathrm{wt} \%$ insoluble solids $\mathrm{Sr} / \mathrm{TRU}$ precipitate to add is: $6.46 \mathrm{~g} / \mathrm{wt} \%$ total Solids Sr/TRU $(17.65 \%)=36.6$ grams. Actually used: 36.64 grams.

5. The amount of blended eluate to add: $69.52 \mathrm{~g} *$ Basis for Eluate (39.75)/Basis for AZ-102 (287.91) = 9.6 grams of eluate. Actually used: 9.61 grams.

The physical properties for the Test ADD-4 blend are listed in Table 14. Mixing a 12.5 wt \% solids slurry with a smaller amount of a $\sim 15 \mathrm{wt} \%$ solids did not significantly change the weight percent solids for the mixture. A sample of the test mixture was submitted for chemical analysis. The results expressed on a wt \% oxide basis are shown in Table B- 40. The agreement between the found and the target composition was reasonable, since the target wt \% was based upon the originally planned compositions for the waste streams. 
WSRC-TR-2001-00203, Rev. 0

Table B- 40: Composition of Test ADD-4 Compared to Target Blend

\begin{tabular}{|c|c|c|c|c|c|}
\hline \multicolumn{2}{c}{ Oxide } & Wt \% & \multicolumn{2}{c|}{ Target Wt \% } & \multicolumn{2}{c|}{ Oxide } & \multicolumn{1}{c|}{ Wt \% } & Target Wt \% \\
\hline $\mathrm{Al}_{2} \mathrm{O}_{3}$ & 27.66 & 23.01 & $\mathrm{P}_{2} \mathrm{O}_{5}$ & 0.94 & 1.39 \\
\hline $\mathrm{BaO}$ & 0.15 & 0.11 & $\mathrm{PbO}$ & 0.07 & 0.28 \\
\hline $\mathrm{CaO}$ & 0.83 & 1.43 & $\mathrm{SiO}_{2}$ & 2.25 & 1.9 \\
\hline $\mathrm{CdO}$ & 4.94 & 4.19 & $\mathrm{SrO}$ & 3.34 & 4.47 \\
\hline $\mathrm{CoO}$ & 0.03 & 0.02 & $\mathrm{TiO}_{2}$ & 0.03 & 0.03 \\
\hline $\mathrm{Cr} \mathrm{O}_{3}$ & 0.35 & 0.28 & $\mathrm{ZnO}$ & 0.18 & 0.12 \\
\hline $\mathrm{CuO}$ & 0.01 & 0.08 & $\mathrm{ZrO}$ & 5.51 & 4.4 \\
\hline $\mathrm{Fe}_{2} \mathrm{O}_{3}$ & 44.22 & 36.39 & $\mathrm{La}_{2} \mathrm{O}_{3}$ & 1.08 & 0.89 \\
\hline $\mathrm{MgO}$ & 0.44 & 0.36 & $\mathrm{~K}_{2} \mathrm{O}$ & 0.08 & 0.02 \\
\hline $\mathrm{MnO}$ & 2.36 & 2.76 & $\mathrm{Ag}_{2} \mathrm{O}$ & 0.11 & 0.06 \\
\hline $\mathrm{MoO}$ & 0.02 & 0 & $\mathrm{CeO}_{2}$ & 0.24 & 0.17 \\
\hline $\mathrm{Na}_{2} \mathrm{O}$ & 5.08 & 9.04 & $\mathrm{Nd}_{2} \mathrm{O}_{3}$ & 0.1 & 0.63 \\
\hline
\end{tabular}

\section{Glass Formulations for AZ-101}

The glass formulation for the AZ-101 blends was obtained from VSL. Table B- 41 ists the formulation provided by VSL. The glass formers used with the AZ-101 blends were borax, lithium hydroxide monohydrate, silica and zinc oxide. Borax provides both $\mathrm{B}_{2} \mathrm{O}_{3}$ and $\mathrm{Na}_{2} \mathrm{O}$ while the other three glass formers provide the remaining oxides necessary for the glass. For the glass made with AZ-101 sludge, AN-107 Sr/TRU precipitate and the AZ-102 blended eluate, one hundred grams of glass should contain 25.57 grams of borax, 17.76 grams of $\mathrm{LiOH}_{\bullet} \mathrm{H}_{2} \mathrm{O}$, and 45.91 grams of silica. The glass that does not contain any Sr/TRU precipitate should contain 24.31 grams of borax, 17.76 grams of $\mathrm{LiOH} \bullet \mathrm{H}_{2} \mathrm{O}, 48.44$ grams of silica and 1.97 grams of zinc oxide per 100 grams of glass. These ratios were used with the amount of blend slurry available to determine the amounts of glass formers to add for each test. 
WSRC-TR-2001-00203, Rev. 0

SRT-RPP-2001-00051, Rev. 0

TRPT-24590-01-00001

Table B- 41 VSL AZ-101 Glass Formulation

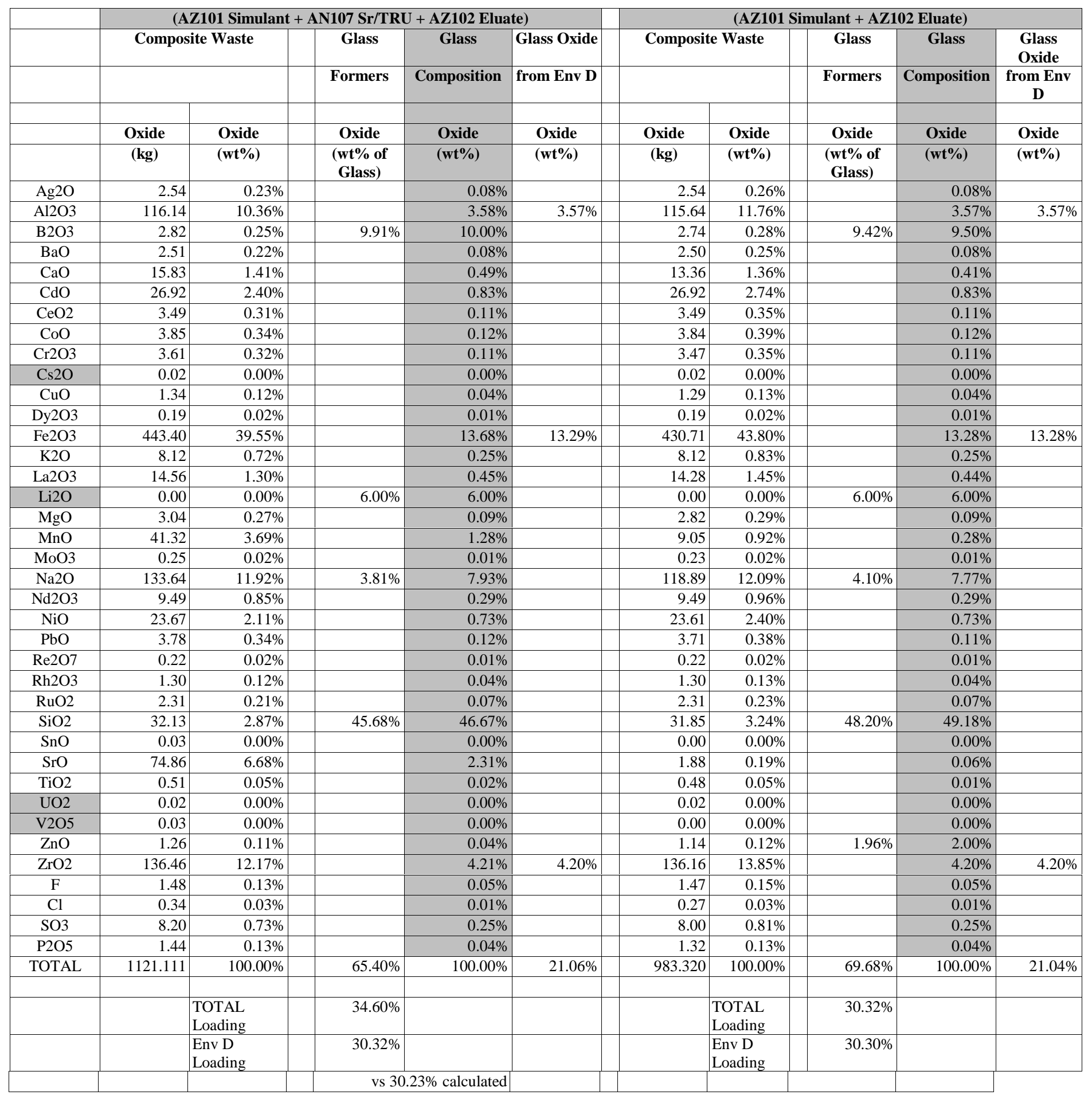




\section{Glass Formulations for AZ-102}

The glass formulation for the AZ-102 blends was obtained from VSL. Table B- 42 lists the formulation provided by VSL. The glass formers used with the AZ-102 blends were borax, lithium hydroxide monohydrate, silica and sodium hydroxide. Borax provides both $\mathrm{B}_{2} \mathrm{O}_{3}$ and some of the $\mathrm{Na}_{2} \mathrm{O}$. The remaining $\mathrm{Na}_{2} \mathrm{O}$ was provided by the sodium hydroxide. The remaining two glass formers provide the remaining oxides necessary for the glass. For the glass made with AZ-102 sludge, AN-107 Sr/TRU precipitate and the AZ-102 blended eluate, one hundred grams of glass should contain 10.3 grams of borax, 14.8 grams of $\mathrm{LiOH} \bullet \mathrm{H}_{2} \mathrm{O}, 47.61$ grams of silica, and 11.38 grams of sodium hydroxide. The glass that does not contain any Sr/TRU precipitate should contain 14.19 grams of borax, 14.8 grams of $\mathrm{LiOH} \bullet \mathrm{H}_{2} \mathrm{O}, 48.52$ grams of silica and 10.57 grams of sodium hydroxide per 100 grams of glass. These ratios were used with the amount of blend slurry available to determine the amounts of glass formers to add for each test. 
Table B- 42: AZ-102 Glass Formulations from VSL

\begin{tabular}{|c|c|c|c|c|c|c|c|c|c|c|}
\hline & & PNNL's & SRS's OLI & Composite Waste & $\begin{array}{c}\text { Glass } \\
\text { Formers }\end{array}$ & Glass & PNNL"s & $\begin{array}{c}\text { Composite } \\
\text { Waste }\end{array}$ & $\begin{array}{c}\text { Glass } \\
\text { Formers }\end{array}$ & Glass \\
\hline & $\overline{A Z 102}$ & $\begin{array}{c}\text { Composition } \\
\text { of }\end{array}$ & AZ-102 & W/OUT Tc Eluate & to be & Composition & AZ102 Melt 1 & $\begin{array}{c}\text { WITH Tc } \\
\text { Eluate }\end{array}$ & to be & Composition \\
\hline & Solid & SR/TRU ppt & Eluate & & Added & & Tc Eluate & & Added & \\
\hline & (wt\% ox.) & (wt\% ox.) & (wt\% ox.) & (wt\% ox) & $\begin{array}{c}\text { (wt\% ox in } \\
\text { Glass) }\end{array}$ & $(w t \%$ ox $)$ & (wt \%) & (wt\% ox) & $\begin{array}{c}\text { (wt \% ox in } \\
\text { Glass) }\end{array}$ & (wt\% ox) \\
\hline $\mathrm{Ag} 2 \mathrm{O}$ & $0.06 \%$ & $0.00 \%$ & $0.00 \%$ & $0.06 \%$ & & $0.019 \%$ & $0.00 \%$ & $0.06 \%$ & & $0.019 \%$ \\
\hline $\mathrm{Al} 2 \mathrm{O} 3$ & $25.09 \%$ & $0.00 \%$ & $0.00 \%$ & $23.02 \%$ & & $7.623 \%$ & $1.83 \%$ & $23.01 \%$ & & $7.619 \%$ \\
\hline $\mathrm{BaO}$ & $0.12 \%$ & $0.03 \%$ & $0.00 \%$ & $0.11 \%$ & & $0.038 \%$ & $0.04 \%$ & $0.11 \%$ & & $0.038 \%$ \\
\hline $\mathrm{BeO}$ & $0.01 \%$ & $0.00 \%$ & & $0.01 \%$ & & $0.003 \%$ & $0.00 \%$ & $0.01 \%$ & & $0.003 \%$ \\
\hline $\mathrm{CaO}$ & $1.51 \%$ & $0.61 \%$ & $0.00 \%$ & $1.43 \%$ & & $0.474 \%$ & $0.76 \%$ & $1.43 \%$ & & $0.474 \%$ \\
\hline $\mathrm{CdO}$ & $4.57 \%$ & $0.00 \%$ & $0.00 \%$ & $4.19 \%$ & & $1.387 \%$ & $0.00 \%$ & $4.19 \%$ & & $1.386 \%$ \\
\hline $\mathrm{CeO} 2$ & $0.19 \%$ & $0.03 \%$ & $0.00 \%$ & $0.17 \%$ & & $0.058 \%$ & $0.00 \%$ & $0.17 \%$ & & $0.058 \%$ \\
\hline $\mathrm{Cl}$ & $0.11 \%$ & & & $0.10 \%$ & & $0.034 \%$ & $4.30 \%$ & $0.10 \%$ & & $0.034 \%$ \\
\hline $\mathrm{CoO}$ & $0.02 \%$ & $0.00 \%$ & $0.00 \%$ & $0.02 \%$ & & $0.007 \%$ & $0.00 \%$ & $0.02 \%$ & & $0.007 \%$ \\
\hline $\mathrm{Cs} 2 \mathrm{O}$ & & & $2.73 \%$ & $0.02 \%$ & & $0.008 \%$ & & $0.02 \%$ & & $0.008 \%$ \\
\hline $\mathrm{CuO}$ & $0.08 \%$ & $0.01 \%$ & $0.00 \%$ & $0.08 \%$ & & $0.025 \%$ & $0.00 \%$ & $0.08 \%$ & & $0.025 \%$ \\
\hline $\mathrm{F}$ & $0.03 \%$ & $0.00 \%$ & & $0.02 \%$ & & $0.008 \%$ & $0.00 \%$ & $0.02 \%$ & & $0.008 \%$ \\
\hline $\mathrm{Fe} 2 \mathrm{O} 3$ & $39.29 \%$ & $4.94 \%$ & $0.01 \%$ & $36.41 \%$ & & $12.056 \%$ & $1.72 \%$ & $36.39 \%$ & & $12.050 \%$ \\
\hline $\mathrm{K} 2 \mathrm{O}$ & $0.00 \%$ & $0.00 \%$ & $2.52 \%$ & $0.02 \%$ & & $0.008 \%$ & $3.23 \%$ & $0.02 \%$ & & $0.008 \%$ \\
\hline $\mathrm{La} 2 \mathrm{O} 3$ & $0.97 \%$ & $0.01 \%$ & $0.00 \%$ & $0.89 \%$ & & $0.296 \%$ & $0.00 \%$ & $0.89 \%$ & & $0.296 \%$ \\
\hline $\mathrm{Li2O}$ & $0.00 \%$ & $0.00 \%$ & & $0.00 \%$ & $5.00 \%$ & $5.000 \%$ & $0.00 \%$ & $0.00 \%$ & $5.00 \%$ & $5.000 \%$ \\
\hline $\mathrm{MgO}$ & $0.39 \%$ & $0.00 \%$ & $0.00 \%$ & $0.36 \%$ & & $0.119 \%$ & $0.02 \%$ & $0.36 \%$ & & $0.119 \%$ \\
\hline $\mathrm{MnO}$ & $0.85 \%$ & $27.02 \%$ & $0.00 \%$ & $2.76 \%$ & & $0.915 \%$ & $0.02 \%$ & $2.76 \%$ & & $0.915 \%$ \\
\hline $\mathrm{MoO} 3$ & $0.00 \%$ & $0.00 \%$ & $0.03 \%$ & $0.00 \%$ & & $0.000 \%$ & $0.00 \%$ & $0.00 \%$ & & $0.000 \%$ \\
\hline $\mathrm{Na} 2 \mathrm{O}$ & $8.40 \%$ & $6.77 \%$ & $89.15 \%$ & $9.02 \%$ & $10.53 \%$ & $13.516 \%$ & $56.94 \%$ & $9.04 \%$ & $10.53 \%$ & $13.524 \%$ \\
\hline $\mathrm{Nd} 2 \mathrm{O} 3$ & $0.68 \%$ & $0.04 \%$ & $0.00 \%$ & $0.63 \%$ & & $0.208 \%$ & $0.00 \%$ & $0.63 \%$ & & $0.208 \%$ \\
\hline $\mathrm{NiO}$ & $2.50 \%$ & $0.02 \%$ & $0.04 \%$ & $2.29 \%$ & & $0.758 \%$ & $0.26 \%$ & $2.29 \%$ & & $0.758 \%$ \\
\hline P2O5 & $1.49 \%$ & $0.21 \%$ & $0.50 \%$ & $1.39 \%$ & & $0.460 \%$ & $0.06 \%$ & $1.39 \%$ & & $0.460 \%$ \\
\hline
\end{tabular}


WSRC-TR-2001-00203, Rev. 0

SRT-RPP-2001-00051, Rev. 0

TRPT-24590-01-00001

\begin{tabular}{|c|c|c|c|c|c|c|c|c|c|c|c|}
\hline & & PNNL's & SRS's OLI & \begin{tabular}{|l|} 
Composite Waste \\
\end{tabular} & $\begin{array}{c}\text { Glass } \\
\text { Formers }\end{array}$ & Glass & PNNL"s & $\begin{array}{c}\begin{array}{c}\text { Composite } \\
\text { Waste }\end{array} \\
\end{array}$ & & $\begin{array}{c}\text { Glass } \\
\text { Formers }\end{array}$ & Glass \\
\hline & $\overline{\text { AZ102 }}$ & $\begin{array}{c}\text { Composition } \\
\text { of }\end{array}$ & AZ-102 & \begin{tabular}{|l|} 
W/OUT Tc Eluate \\
\end{tabular} & to be & Composition & AZ102 Melt 1 & $\begin{array}{c}\text { WITH Tc } \\
\text { Eluate }\end{array}$ & & to be & Composition \\
\hline & Solid & SR/TRU ppt & Eluate & & Added & & Tc Eluate & & & Added & \\
\hline & $(\mathrm{wt} \%$ ox. $)$ & (wt\% ox.) & (wt\% ox.) & $(\mathrm{wt} \%$ ox $)$ & $\begin{array}{c}\text { (wt\% ox in } \\
\text { Glass) }\end{array}$ & $(\mathbf{w t} \%$ ox $)$ & $(\mathrm{wt} \%)$ & $(\mathbf{w t} \%$ ox $)$ & & $\begin{array}{c}\text { (wt \% ox in } \\
\text { Glass) }\end{array}$ & $(\mathrm{wt} \%$ ox $)$ \\
\hline $\mathrm{PbO}$ & $0.29 \%$ & $0.16 \%$ & $0.08 \%$ & $0.28 \%$ & & $0.091 \%$ & $0.00 \%$ & $0.28 \%$ & & & $0.091 \%$ \\
\hline $\mathrm{SO} 3$ & $0.06 \%$ & $0.00 \%$ & & $0.05 \%$ & & $0.018 \%$ & & $0.05 \%$ & & & $0.018 \%$ \\
\hline $\mathrm{SiO} 2$ & $2.06 \%$ & $0.00 \%$ & $0.37 \%$ & $1.89 \%$ & $47.37 \%$ & $47.997 \%$ & $17.81 \%$ & $1.90 \%$ & & $47.37 \%$ & $48.000 \%$ \\
\hline $\mathrm{SnO} 2$ & $0.54 \%$ & $0.00 \%$ & $0.00 \%$ & $0.49 \%$ & & $0.163 \%$ & & $0.49 \%$ & & & $0.162 \%$ \\
\hline $\mathrm{SrO}$ & $0.07 \%$ & $60.00 \%$ & & $4.47 \%$ & & $1.480 \%$ & $0.00 \%$ & $4.47 \%$ & & & $1.480 \%$ \\
\hline TiO2 & $0.03 \%$ & $0.00 \%$ & & $0.03 \%$ & & $0.011 \%$ & $0.00 \%$ & $0.03 \%$ & & & $0.011 \%$ \\
\hline $\mathrm{UO} 2$ & $5.27 \%$ & $0.00 \%$ & $2.74 \%$ & $4.86 \%$ & & $1.611 \%$ & $0.00 \%$ & $4.86 \%$ & & & $1.610 \%$ \\
\hline $\mathrm{V} 2 \mathrm{O} 5$ & $0.01 \%$ & $0.00 \%$ & & $0.01 \%$ & & $0.004 \%$ & $0.00 \%$ & $0.01 \%$ & & & $0.004 \%$ \\
\hline $\mathrm{Y} 2 \mathrm{O} 3$ & $0.05 \%$ & $0.00 \%$ & & $0.04 \%$ & & $0.014 \%$ & $0.00 \%$ & $0.04 \%$ & & & $0.014 \%$ \\
\hline $\mathrm{ZnO}$ & $0.13 \%$ & $0.04 \%$ & $0.00 \%$ & $0.12 \%$ & & $0.040 \%$ & $0.02 \%$ & $0.12 \%$ & & & $0.039 \%$ \\
\hline $\mathrm{ZrO} 2$ & $4.80 \%$ & $0.00 \%$ & $0.00 \%$ & $4.41 \%$ & & $1.459 \%$ & $0.00 \%$ & $4.40 \%$ & & & $1.458 \%$ \\
\hline TOTAL & $100.00 \%$ & $100.00 \%$ & $100.00 \%$ & $100.00 \%$ & $66.890 \%$ & $100.00 \%$ & $100.00 \%$ & $100.00 \%$ & & $66.890 \%$ & $100.000 \%$ \\
\hline & & & & & & & & & & & \\
\hline Blending & 250.00 & 20.00 & 2.479 & $\begin{array}{l}\text { Total Waste } \\
\text { Loading }\end{array}$ & $33.110 \%$ & & 0.1367 & \multicolumn{2}{|c|}{ Total Loading } & $33.110 \%$ & \\
\hline \multicolumn{2}{|c|}{ Ratio (wt of oxides) } & & 272.48 & $\begin{array}{l}\text { Envelope D } \\
\text { Loading }\end{array}$ & $30.378 \%$ & & 272.62 & \multicolumn{2}{|l|}{ D Loading } & $30.363 \%$ & \\
\hline & & & & & & & & & & & \\
\hline & & & & Al from Enve D & $7.623 \%$ & & & & $\mathrm{Al}$ & $7.619 \%$ & \\
\hline & & & & Fe from Enve D & $11.936 \%$ & & & & $\mathrm{Fe}$ & $11.930 \%$ & \\
\hline & & & & Zr from Enve $D$ & $1.459 \%$ & & & & $\mathrm{Zr}$ & $1.458 \%$ & \\
\hline & & & & & & & & & & & \\
\hline & & & & $\begin{array}{c}(\mathrm{al}+\mathrm{fe}+\mathrm{zr}) \text { from } \\
\mathrm{AZ102}\end{array}$ & $21.017 \%$ & & & & & $21.007 \%$ & \\
\hline
\end{tabular}


Table B- 43: OLI Model Results of Blended AZ-102 Eluate

\begin{tabular}{||l|c|c|c|c||}
\hline \hline ESP V-6.2 & \multicolumn{2}{|c|}{ PROCESS:ELBLEND } & \multicolumn{2}{c||}{$10 / 12 / 2000$ PAGE 4} \\
\hline STREAM: & Blend Eluate & & & \\
\hline TO & & & & \\
\hline FROM Vent C02 & frm Storage & & & \\
\hline Phases ------ $>$ & Aqueous & Solid & Vapor & Organic \\
\hline Temperature, C & 29.6756 & 29.6756 & 29.6756 & 29.6756 \\
\hline Pressure, atm & 1. & 1. & 1. & 1. \\
\hline pH & 7.72549 & & & 0.0 \\
\hline Total mol/hr & 3606.02 & 2.42085 & 0.0 & 0.0 \\
\hline \multicolumn{1}{|c|}{ Chemical } & mol/hr ------- & mol/hr -- & mol/hr & mol/hr \\
\hline H20 & 3350.21 & 0.0 & 0.0 & 0.0 \\
\hline C02 & 0.106212 & 0.0 & 0.0 & 0.0 \\
\hline GLUCONACID & $9.6899 \mathrm{E}-07$ & 0.0 & 0.0 & 0.0 \\
\hline ACETACID & $4.0391 \mathrm{E}-07$ & 0.0 & 0.0 & 0.0 \\
\hline H2SO4 & $2.8573 \mathrm{E}-25$ & 0.0 & 0.0 & 0.0 \\
\hline HCL & $9.6431 \mathrm{E}-14$ & 0.0 & 0.0 & 0.0 \\
\hline HN02 & $1.8790 \mathrm{E}-04$ & 0.0 & 0.0 & 0.0 \\
\hline HN03 & $2.2035 \mathrm{E}-08$ & 0.0 & 0.0 & 0.0 \\
\hline N2 & 0.0205223 & 0.0 & 0.0 & 0.0 \\
\hline 02 & 0.0104382 & 0.0 & 0.0 & 0.0 \\
\hline S03 & $4.1746 \mathrm{E}-29$ & 0.0 & 0.0 & 0.0 \\
\hline BAC03 & $1.1803 \mathrm{E}-07$ & 0.0 & 0.0 & 0.0 \\
\hline CSACET & $2.1572 \mathrm{E}-06$ & 0.0 & 0.0 & 0.0 \\
\hline CSCL & 0.0158577 & 0.0 & 0.0 & 0.0 \\
\hline CSGLYCOL & $5.0074 \mathrm{E}-04$ & 0.0 & 0.0 & 0.0 \\
\hline CSN03 & 0.216461 & 0.0 & 0.0 & 0.0 \\
\hline FEIIICTRT & $6.5947 \mathrm{E}-10$ & 0.0 & 0.0 & 0.0 \\
\hline FEIIIHEDTA & $1.2611 \mathrm{E}-09$ & 0.0 & 0.0 & 0.0 \\
\hline FEIIIOH3 & $1.9736 \mathrm{E}-06$ & 0.0189066 & 0.0 & 0.0 \\
\hline FENTA & $7.3871 \mathrm{E}-08$ & 0.0 & 0.0 & 0.0 \\
\hline ALOH3 & $1.3369 \mathrm{E}-09$ & 0.0 & 0.0 & 0.0 \\
\hline GLYCOLACID & $1.9115 \mathrm{E}-05$ & 0.0 & 0.0 & 0.0 \\
\hline H21DA & $2.7503 \mathrm{E}-07$ & 0.0 & 0.0 & 0.0 \\
\hline H2SIO3 & 0.0871667 & 0.0 & 0.0 & 0.0 \\
\hline BAGLYCOL2 & $1.9886 \mathrm{E}-10$ & 0.0 & 0.0 & 0.0 \\
\hline H3AS04 & $2.6280 \mathrm{E}-11$ & 0.0 & 0.0 & 0.0 \\
\hline H3NTA & $5.3357 \mathrm{E}-15$ & 0.0 & 0.0 & 0.0 \\
\hline H3PO4 & $9.5618 \mathrm{E}-09$ & 0.0 & 0.0 & 0.0 \\
\hline \hline & $5.8385 \mathrm{E}-20$ & 0.0 & 0.0 & 0.0 \\
\hline
\end{tabular}


TABLE B- 43: OLI Model of Blended AZ-102Eluate, Cont.

\begin{tabular}{||l|c|c|c|c||}
\hline \multicolumn{1}{|c|}{ Phases ------ $>$} & Aqueous & Solid & Vapor & Organic \\
\hline \multicolumn{1}{|c|}{ Chemical } & mol/hr & $\mathrm{mol} / \mathrm{hr}$ & $\mathrm{mol} / \mathrm{hr}$ & $\mathrm{mol} / \mathrm{hr}$ \\
\hline BAOX & $4.5167 \mathrm{E}-07$ & 0.0 & 0.0 & 0.0 \\
\hline BAS04 & $3.0958 \mathrm{E}-06$ & 0.016869 & 0.0 & 0.0 \\
\hline BOH3 & 0.942509 & 0.0 & 0.0 & 0.0 \\
\hline CAC03 & $1.4262 \mathrm{E}-05$ & 0.0 & 0.0 & 0.0 \\
\hline KCL & $9.0421 \mathrm{E}-04$ & 0.0 & 0.0 & 0.0 \\
\hline KGLYCOLAT & 0.00131538 & 0.0 & 0.0 & 0.0 \\
\hline CAGLYCOL2 & $7.1499 \mathrm{E}-08$ & 0.0 & 0.0 & 0.0 \\
\hline NAACET & $2.9229 \mathrm{E}-04$ & 0.0 & 0.0 & 0.0 \\
\hline NABOH4 & 0.0207674 & 0.0 & 0.0 & 0.0 \\
\hline NAGLYCOLAT & 0.0946655 & 0.0 & 0.0 & 0.0 \\
\hline NAHC03 & 1.44913 & 0.0 & 0.0 & 0.0 \\
\hline NAHS103 & 0.0904845 & 0.01 & 0.0 & 0.0 \\
\hline NAN03 & 0.555785 & 0.0 & 0.0 & 0.0 \\
\hline NIC204 & $1.0457 \mathrm{E}-05$ & 0.0 & 0.0 & 0.0 \\
\hline NIGLYCOL2 & $2.2136 \mathrm{E}-12$ & 0.0 & 0.0 & 0.0 \\
\hline NIOH2 & $4.3261 \mathrm{E}-14$ & 0.0 & 0.0 & 0.0 \\
\hline NIS04 & $9.3056 \mathrm{E}-11$ & 0.0 & 0.0 & 0.0 \\
\hline CAS04 & $2.0053 \mathrm{E}-05$ & 0.0 & 0.0 & 0.0 \\
\hline OXALAC & $2.7016 \mathrm{E}-11$ & 0.0 & 0.0 & 0.0 \\
\hline PBC204 & $7.0052 \mathrm{E}-05$ & 0.0 & 0.0 & 0.0 \\
\hline PBGLYCOL2 & $1.4194 \mathrm{E}-11$ & 0.0 & 0.0 & 0.0 \\
\hline PBHP04 & $1.8065 \mathrm{E}-10$ & 0.0 & 0.0 & 0.0 \\
\hline PBN022 & $2.7099 \mathrm{E}-06$ & 0.0 & 0.0 & 0.0 \\
\hline PEN032 & $3.3058 \mathrm{E}-09$ & 0.0 & 0.0 & 0.0 \\
\hline PBO & $2.1180 \mathrm{E}-11$ & 0.0 & 0.0 & 0.0 \\
\hline S102 & 0.0989201 & 0.0 & 0.0 & 0.0 \\
\hline CITRAC & $1.5419 \mathrm{E}-13$ & 0.0 & 0.0 & 0.0 \\
\hline U02C204 & $4.7198 \mathrm{E}-07$ & 0.0 & 0.0 & 0.0 \\
\hline U02CL2 & $1.0758 \mathrm{E}-14$ & 0.0 & 0.0 & 0.0 \\
\hline U02CO3 & $6.0895 \mathrm{E}-06$ & 0.0 & 0.0 & 0.0 \\
\hline U020H2 & $1.3572 \mathrm{E}-08$ & 0.0 & 0.0 & 0.0 \\
\hline U02SO4 & $3.9618 \mathrm{E}-11$ & 0.0 & 0.0 & 0.0 \\
\hline OHION & $5.3822 \mathrm{E}-05$ & 0.0 & 0.0 & 0.0 \\
\hline ALACETION & $1.2602 \mathrm{E}-18$ & 0.0 & 0.0 & 0.0 \\
\hline ALEDTAION & $5.0310 \mathrm{E}-11$ & 0.0 & 0.0 & 0.0 \\
\hline ALION & $4.6230 \mathrm{E}-16$ & 0.0 & 0.0 & 0.0 \\
\hline ALOH2ION & $7.4188 \mathrm{E}-12$ & 0.0 & 0.0 & 0.0 \\
\hline ALOH4ION & $4.4593 \mathrm{E}-08$ & 0.0 & 0.0 & 0.0 \\
\hline \hline
\end{tabular}


TABLE B- 43: OLI Model of Blended AZ-102Eluate, Cont.

\begin{tabular}{|l|c|c|c|c||}
\hline \hline \multicolumn{1}{|c|}{ Phases ------ $>$ Chemical } & Aqueous & Solid & Vapor & Organic \\
\hline ALOHION & mol/hr & mol/hr & mol/hr & mol/hr \\
\hline ALS0410N & $7.4169 \mathrm{E}-14$ & 0.0 & 0.0 & 0.0 \\
\hline ARS0410N & $1.9155 \mathrm{E}-16$ & 0.0 & 0.0 & 0.0 \\
\hline BAACETION & $1.2578 \mathrm{E}-06$ & 0.0 & 0.0 & 0.0 \\
\hline BACTRTION & $2.7343 \mathrm{E}-10$ & 0.0 & 0.0 & 0.0 \\
\hline BAEDTAION & $1.0890 \mathrm{E}-08$ & 0.0 & 0.0 & 0.0 \\
\hline BAGLYCOLION & $5.3950 \mathrm{E}-09$ & 0.0 & 0.0 & 0.0 \\
\hline BAHC0310N & $2.6335 \mathrm{E}-06$ & 0.0 & 0.0 & 0.0 \\
\hline BAION & $2.8932 \mathrm{E}-05$ & 0.0 & 0.0 & 0.0 \\
\hline BANTAION & $5.2532 \mathrm{E}-08$ & 0.0 & 0.0 & 0.0 \\
\hline BAOHION & $1.3097 \mathrm{E}-12$ & 0.0 & 0.0 & 0.0 \\
\hline BOH4ION & 0.0548474 & 0.0 & 0.0 & 0.0 \\
\hline CAACETION & $5.8111 \mathrm{E}-09$ & 0.0 & 0.0 & 0.0 \\
\hline CACTRTION & $1.3400 \mathrm{E}-05$ & 0.0 & 0.0 & 0.0 \\
\hline CAEDTAION & $9.3051 \mathrm{E}-05$ & 0.0 & 0.0 & 0.0 \\
\hline CAGLYCOLION & $6.8126 \mathrm{E}-06$ & 0.0 & 0.0 & 0.0 \\
\hline CAH2BO3ION & $3.4563 \mathrm{E}-06$ & 0.0 & 0.0 & 0.0 \\
\hline CAH2PO4ION & $2.5369 \mathrm{E}-07$ & 0.0 & 0.0 & 0.0 \\
\hline CAHC0310N & $6.1666 \mathrm{E}-05$ & 0.0 & 0.0 & 0.0 \\
\hline CAHSI03ION & $2.8719 \mathrm{E}-08$ & 0.0 & 0.0 & 0.0 \\
\hline CAION & $4.6280 \mathrm{E}-04$ & 0.0 & 0.0 & 0.0 \\
\hline CAN0310N & $1.2247 \mathrm{E}-04$ & 0.0 & 0.0 & 0.0 \\
\hline CANTAION & $4.9304 \mathrm{E}-05$ & 0.0 & 0.0 & 0.0 \\
\hline CAOHION & $9.3027 \mathrm{E}-10$ & 0.0 & 0.0 & 0.0 \\
\hline CAP0410N & $2.6493 \mathrm{E}-06$ & 0.0 & 0.0 & 0.0 \\
\hline CITRATION & 0.0144824 & 0.0 & 0.0 & 0.0 \\
\hline CLION & 11.7792 & 0.0 & 0.0 & 0.0 \\
\hline C0310N & 0.159526 & 0.0 & 0.0 & 0.0 \\
\hline CR0410N & 0.626696 & 0.0 & 0.0 & 0.0 \\
\hline CSCTRTION & $1.3675 \mathrm{E}-04$ & 0.0 & 0.0 & 0.0 \\
\hline CSION & 0.642841 & 0.0 & 0.0 & 0.0 \\
\hline CSS0410N & 0.00990417 & 0.0 & 0.0 & 0.0 \\
\hline EDTAION & $3.8966 \mathrm{E}-08$ & 0.0 & 0.0 & 0.0 \\
\hline FEIIIC204ION & $5.2426 \mathrm{E}-08$ & 0.0 & 0.0 & 0.0 \\
\hline FEIIICLION & $3.3448 \mathrm{E}-18$ & 0.0 & 0.0 & 0.0 \\
\hline FEIIIEDTAION & 0.00502015 & 0.0 & 0.0 & 0.0 \\
\hline FEIIIGLUCOION & $2.1458 \mathrm{E}-16$ & 0.0 & 0.0 & 0.0 \\
\hline FEIIIGLYCOION & $3.2185 \mathrm{E}-15$ & 0.0 & 0.0 & 0.0 \\
\hline FEIIIION & $4.6484 \mathrm{E}-16$ & 0.0 & 0.0 & 0.0 \\
\hline
\end{tabular}


TABLE B- 43: OLI Model of Blended AZ-102Eluate, Cont.

\begin{tabular}{|l|c|c|c|c||}
\hline \hline \multicolumn{1}{|c|}{ Phases ------ $>$ Chemical } & Aqueous & Solid & Vapor & Organic \\
\hline FEIIN03ION & $2.3693 \mathrm{E}-18$ & 0.0 & 0.0 & $\mathrm{~mol} / \mathrm{hr}$ \\
\hline FEIIIOH2ION & $8.5513 \mathrm{E}-09$ & 0.0 & 0.0 & 0.0 \\
\hline FEIIIOH4ION & $9.6438 \mathrm{E}-08$ & 0.0 & 0.0 & 0.0 \\
\hline FEIIIOHION & $2.1894 \mathrm{E}-11$ & 0.0 & 0.0 & 0.0 \\
\hline FEIIIS04ION & $8.2159 \mathrm{E}-18$ & 0.0 & 0.0 & 0.0 \\
\hline GLUCONAION & 0.0269082 & 0.0 & 0.0 & 0.0 \\
\hline GLYCOLATION & 0.274058 & 0.0 & 0.0 & 0.0 \\
\hline H2AS04ION & $1.3588 \mathrm{E}-05$ & 0.0 & 0.0 & 0.0 \\
\hline H2CITRATION & $1.1494 \mathrm{E}-08$ & 0.0 & 0.0 & 0.0 \\
\hline H2EDTAION & $1.4281 \mathrm{E}-08$ & 0.0 & 0.0 & 0.0 \\
\hline H2NTAION & $5.1008 \mathrm{E}-09$ & 0.0 & 0.0 & 0.0 \\
\hline H2PO4ION & 0.0103942 & 0.0 & 0.0 & 0.0 \\
\hline H2SI04ION & $7.5677 \mathrm{E}-08$ & 0.0 & 0.0 & 0.0 \\
\hline H3EDTAION & $3.4942 \mathrm{E}-14$ & 0.0 & 0.0 & 0.0 \\
\hline H31DAION & $9.8546 \mathrm{E}-13$ & 0.0 & 0.0 & 0.0 \\
\hline H3SI04ION & 0.00157162 & 0.0 & 0.0 & 0.0 \\
\hline H4NTAION & $1.4728 \mathrm{E}-21$ & 0.0 & 0.0 & 0.0 \\
\hline H5EDTAION & $8.1108 \mathrm{E}-26$ & 0.0 & 0.0 & 0.0 \\
\hline HAS0410N & 0.00141508 & 0.0 & 0.0 & 0.0 \\
\hline HCITRATION & $1.1864 \mathrm{E}-04$ & 0.0 & 0.0 & 0.0 \\
\hline HC0310N & 6.83996 & 0.0 & 0.0 & 0.0 \\
\hline HCR0410N & 0.00428778 & 0.0 & 0.0 & 0.0 \\
\hline HEDTAION & $9.1866 \mathrm{E}-07$ & 0.0 & 0.0 & 0.0 \\
\hline HIDAION & 0.0620844 & 0.0 & 0.0 & 0.0 \\
\hline HION & $1.5071 \mathrm{E}-06$ & 0.0 & 0.0 & 0.0 \\
\hline HNTAION & 0.00344011 & 0.0 & 0.0 & 0.0 \\
\hline HOXALATION & $1.0353 \mathrm{E}-04$ & 0.0 & 0.0 & 0.0 \\
\hline HP0410N & 0.311811 & 0.0 & 0.0 & 0.0 \\
\hline HSI03ION & 0.0026636 & 0.0 & 0.0 & 0.0 \\
\hline HS0410N & $7.3859 \mathrm{E}-07$ & 0.0 & 0.0 & 0.0 \\
\hline IDAION & 0.00574265 & 0.0 & 0.0 & 0.0 \\
\hline KCTRTION & $6.7709 \mathrm{E}-04$ & 0.0 & 0.0 & 0.0 \\
\hline KEDTAION & $1.4654 \mathrm{E}-09$ & 0.0 & 0.0 & 0.0 \\
\hline KION & 2.38808 & 0.0 & 0.0 & 0.0 \\
\hline KS0410N & 0.0590995 & 0.0 & 0.0 & 0.0 \\
\hline M00410N & 0.0108804 & 0.0 & 0.0 & 0.0 \\
\hline NAC0310N & 0.0497212 & 0.0 & 0.0 & 0.0 \\
\hline NACTRTION & 0.0580374 & 0.0 & 0.0 & 0.0 \\
\hline NAEDTAION & $1.3729 \mathrm{E}-07$ & 0.0 & 0.0 & 0.0 \\
\hline
\end{tabular}


TABLE B- 43: OLI Model of Blended AZ-102Eluate, Cont.

\begin{tabular}{|l|c|c|c|c||}
\hline \multicolumn{1}{|c|}{ Phases ------ $>$} & Aqueous & Solid & Vapor & Organic \\
\hline \multicolumn{1}{|c|}{ Chemical } & mol/hr & $\mathrm{mol} / \mathrm{hr}$ & $\mathrm{mol} / \mathrm{hr}$ & $\mathrm{mol} / \mathrm{hr}$ \\
\hline NAION & 128.849 & 0.0 & 0.0 & 0.0 \\
\hline NANTAION & $8.3131 \mathrm{E}-04$ & 0.0 & 0.0 & 0.0 \\
\hline NAS0410N & 0.492613 & 0.0 & 0.0 & 0.0 \\
\hline NIACETION & $4.6688 \mathrm{E}-14$ & 0.0 & 0.0 & 0.0 \\
\hline NICLION & $3.4421 \mathrm{E}-12$ & 0.0 & 0.0 & 0.0 \\
\hline NICTRTION & $2.2865 \mathrm{E}-09$ & 0.0 & 0.0 & 0.0 \\
\hline NIEDTAION & 0.0217025 & 0.0 & 0.0 & 0.0 \\
\hline NIGLYCOLION & $6.9708 \mathrm{E}-11$ & 0.0 & 0.0 & 0.0 \\
\hline NIION & $1.5804 \mathrm{E}-09$ & 0.0 & 0.0 & 0.0 \\
\hline NIN03ION & $3.3991 \mathrm{E}-10$ & 0.0 & 0.0 & 0.0 \\
\hline NINTAION & $1.8203 \mathrm{E}-05$ & 0.0 & 0.0 & 0.0 \\
\hline NIOHEDTAION & $1.0735 \mathrm{E}-05$ & 0.0 & 0.0 & 0.0 \\
\hline NIOHION & $2.0009 \mathrm{E}-12$ & 0.0 & 0.0 & 0.0 \\
\hline N0210N & 15.3157 & 0.0 & 0.0 & 0.0 \\
\hline N0310N & 73.0901 & 0.0 & 0.0 & 0.0 \\
\hline NTAION & $6.7519 \mathrm{E}-05$ & 0.0 & 0.0 & 0.0 \\
\hline ACETATEION & $4.2606 \mathrm{E}-05$ & 0.0 & 0.0 & 0.0 \\
\hline OXALATION & 3.13739 & 0.0 & 0.0 & 0.0 \\
\hline PBACETION & $1.9444 \mathrm{E}-12$ & 0.0 & 0.0 & 0.0 \\
\hline PBCLION & $3.9683 \mathrm{E}-09$ & 0.0 & 0.0 & 0.0 \\
\hline PBEDTAION & 0.0170702 & 0.0 & 0.0 & 0.0 \\
\hline PBGLYCOLION & $3.5804 \mathrm{E}-10$ & 0.0 & 0.0 & 0.0 \\
\hline PBION & $1.0838 \mathrm{E}-08$ & 0.0 & 0.0 & 0.0 \\
\hline PBN0210N & $1.0170 \mathrm{E}-06$ & 0.0 & 0.0 & 0.0 \\
\hline PBN0310N & $1.1275 \mathrm{E}-08$ & 0.0 & 0.0 & 0.0 \\
\hline PBNTAION & $5.1940 \mathrm{E}-05$ & 0.0 & 0.0 & 0.0 \\
\hline PBOHION & $1.5511 \mathrm{E}-09$ & 0.0 & 0.0 & 0.0 \\
\hline P0410N & $8.1644 \mathrm{E}-05$ & 0.0 & 0.0 & 0.0 \\
\hline SI03ION & $5.1819 \mathrm{E}-07$ & 0.0 & 0.0 & 0.0 \\
\hline S0410N & 6.81661 & 0.0 & 0.0 & 0.0 \\
\hline \hline
\end{tabular}


TABLE B- 43: OLI Model of Blended AZ-102Eluate, Cont.

\begin{tabular}{|l|c|c|c|c||}
\hline \multicolumn{1}{|c|}{ Phases ------ } & Aqueous & Solid & Vapor & Organic \\
\hline Chemical & mol/hr & $\mathrm{mol} / \mathrm{hr}$ & $\mathrm{mol} / \mathrm{hr}$ & $\mathrm{mol} / \mathrm{hr}$ \\
\hline U0220H2ION & 0.484275 & 0.0 & 0.0 & 0.0 \\
\hline U02ACION & $5.1305 \mathrm{E}-14$ & 0.0 & 0.0 & 0.0 \\
\hline U02C2042ION & $1.3798 \mathrm{E}-13$ & 0.0 & 0.0 & 0.0 \\
\hline U02CLION & $1.2039 \mathrm{E}-04$ & 0.0 & 0.0 & 0.0 \\
\hline U02CO32ION & 0.4647755 & 0.0 & 0.0 & 0.0 \\
\hline U02CTRTION & $2.6118 \mathrm{E}-08$ & 0.0 & 0.0 & 0.0 \\
\hline U02HEDTAION & $1.8033 \mathrm{E}-12$ & 0.0 & 0.0 & 0.0 \\
\hline U0210N & $5.2921 \mathrm{E}-11$ & 0.0 & 0.0 & 0.0 \\
\hline U02NTAION & $1.2949 \mathrm{E}-08$ & 0.0 & 0.0 & 0.0 \\
\hline U020HION & $6.0016 \mathrm{E}-09$ & 0.0 & 0.0 & 0.0 \\
\hline NAALC03OH2 & 0.0 & 1.95539 & 0.0 & 0.0 \\
\hline NA2C204 & 0.0 & 0.343564 & 0.0 & 0.0 \\
\hline CAC204.lH20 & 0.0 & 0.0760928 & 0.0 & 0.0 \\
\hline PBM004 & 0.0 & 0.0100275 & 0.0 & 0.0 \\
\hline Total g/hr & 71332.1 & 348.364 & 0.0 & 0.0 \\
\hline Volume, L/hr & 64.4715 & 0.11796 & 0.0 & 0.0 \\
\hline Enthalpy, cal/hr & $-2.4549 \mathrm{E}+08$ & $-1.0689 \mathrm{E}+06$ & 0.0 & 0.0 \\
\hline Density, g/L & 1106.4 & 2953.2 & & \\
\hline Vapor fraction & 0.0 & 0.0 & 0.0 & 0.0 \\
\hline Solid fraction & 0.0 & 1.0 & 0.0 & 0.0 \\
\hline organic fraction & 0.0 & 0.0 & 0.0 & 0.0 \\
\hline Osmotic Pres, atm & 85.3729 & & & \\
\hline Redox Pot, volts & 0.0 & & & \\
\hline E-Con, 1/ohm-cm & 0.135226 & & & \\
\hline $\begin{array}{l}\text { E-Con, cm2/ohm- } \\
\text { mol }\end{array}$ & 41.7649 & & & \\
\hline Abs Visc, cP & 1.04263 & & & \\
\hline Rel Visc & 1.29744 & & & \\
\hline Ionic Strength & 2.37865 & & & \\
\hline & & & & \\
\hline
\end{tabular}

